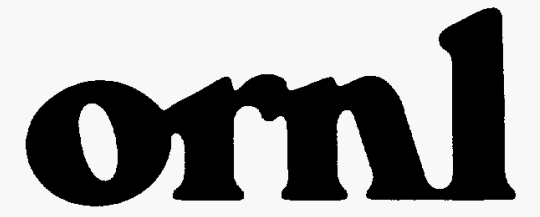

OAK RIDGE

NATIONAL

LABORATORY

rockntrob hatrin


(1)

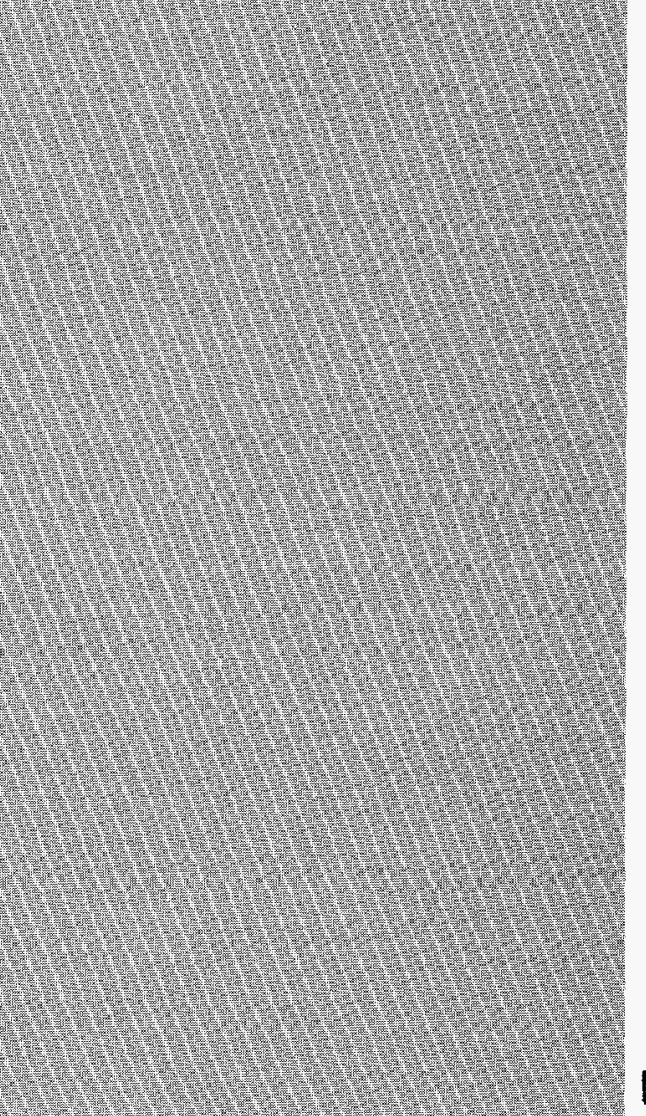

WAHAED ANO OPERATED BY

LOCWHEEO WATN ENEREY RESEARCH CORPORATIO: FERTHE UTIEOSTATES

DEPAHIUENT OF ENERGY
ORNL/TM-12884

ENVIRONMENTAL SCIENCES DIVISION

RECEIVED

AUG 261996

\section{OSTI \\ REPORT ON THE BIOLOGICAL MONITORING PROGRAM FOR BEAR CREEK AT THE OAK RIDGE Y-12 PLANT, OAK RIDGE, TENNESSEE (1989-1994)}

R. L. Hinzman (editor)

Environmental Sciences Division

Publication No. 4357

April 1996

DISTAISTION OF THIS DOCUMENT IS UNLMITED<smiles>[AlH2]</smiles>

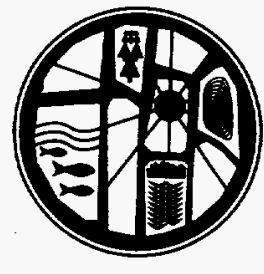

MASTER 
This report has been reproduced directly from the best available copy.

Aveilable to DOE and DOE contractors from the Office of Scientific and Technical Information, P.O. Box 62, Oak Ridge, TN 37831; prices available from (423) 576-8401, FTS 626-8401.

Available to the public from the National Technical information Service, U.S. Department of Commerce, 5285 Port Royal Rd., Springfield, VA 22161.

This report was prepared as an account of work sponsored by an agency of the United States Government. Neither the United States Government nor any agency thereot, nor any of their employees, makes any warranty, express or implied, or assumes any legal liability or responsibility for the accuracy, completeness, or usefulness of any information, apparatus, product, or process disclosed, or represents that its use would not infringe privately owned rights. Reference herein to any specific commercial product, process, or service by trade name, trademark, manufacturer, or otherwise, does not necessarily constitute or imply its endorsement, recommendation, or favoring by the United States Government or any agency thereof. The views and opinions of authors expressed herein do not necessarily state or reflect those of the United States Government or any agency thereof. 


\title{
REPORT ON THE BIOLOGICAL MONITORING PROGRAM FOR BEAR CREEK AT THE OAK RIDGE Y-12 PLANT, OAK RIDGE, TENNESSEE, 1989-1994
}

\author{
R. L. Hinzman (editor) \\ J. J. Beauchamp, G. F. Cada, S. W. Christensen, M. J. Peterson, T. L. Phipps, W. K. Roy, \\ E. M. Schilling, J. G. Smith, M. R. Smith, G. R. Southworth, A. J. Stewart, \\ L. F. Wicker, and J. A. Wojtowicz \\ Environmental Sciences Division \\ Publication No. 4357
}

April 1996

\author{
Prepared by the \\ OAK RIDGE NATIONAL LABORATORY \\ Oak Ridge, Tennessee 37831-6285 \\ managed by \\ LOCKHEED MARTIN ENERGY RESEARCH CORP. \\ for the \\ U.S. DEPARTMENT OF ENERGY \\ under contract DE-AC05-96OR22464
}




\section{DISCLAIMER}

Portions of this document may be illegible in electronic image products. Images are produced from the best available original document. 


\section{CONTENTS}

Page

FIGURES $\ldots \ldots \ldots \ldots \ldots \ldots \ldots \ldots \ldots \ldots \ldots \ldots \ldots \ldots \ldots \ldots \ldots \ldots$ vii

TABLES $\ldots \ldots \ldots \ldots \ldots \ldots \ldots \ldots \ldots \ldots \ldots \ldots \ldots \ldots \ldots \ldots \ldots \ldots$

LIST OF ACRONYMS $\ldots \ldots \ldots \ldots \ldots \ldots \ldots \ldots \ldots \ldots \ldots \ldots \ldots \ldots$

ACKNOWLEDGMENTS $\ldots \ldots \ldots \ldots \ldots \ldots \ldots \ldots \ldots \ldots \ldots \ldots \ldots \ldots$ xvii

EXECUTTVE SUMMARY $\ldots \ldots \ldots \ldots \ldots \ldots \ldots \ldots \ldots \ldots \ldots \ldots \ldots \ldots$

1. INTRODUCTION ( $R$. L. Hinzman and $G . R$ Southworth) $\ldots \ldots \ldots \ldots \ldots \ldots$ 1-1

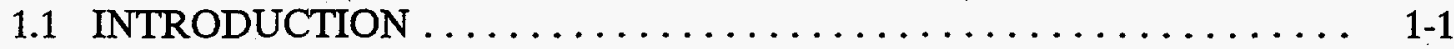

2. DESCRIPTION OF BEAR CREEK WATERSHED ( $R$. L. Hinzman,

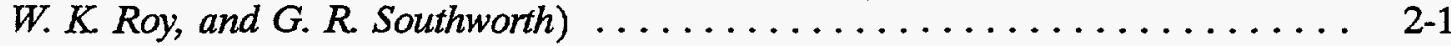

2.1 DESCRIPTION OF STUDY AREA ................. 2-1

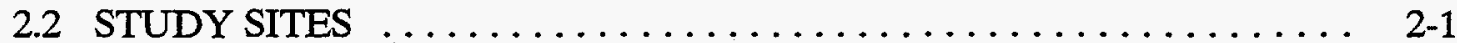





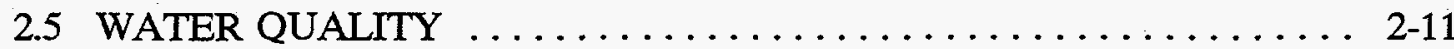

2.6 AMBIENT TEMPERATURE REGIMES ............... 2-12

3. TOXICITY MONITORING (A. J. Stewart, L. F. Wicker, and T. L. Phipps) . . . 3-1

3.1 INTRODUCTION .......................... 3-1

3.2 METHODS AND MATERIALS $\ldots \ldots \ldots \ldots \ldots \ldots \ldots \ldots \ldots \ldots \ldots$ 3-1



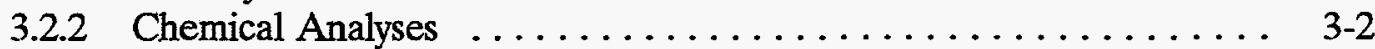



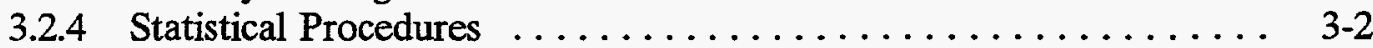

3.3 RESULTS .............................. $3-5$

3.3.1 Toxicity Test Acceptability $\ldots \ldots \ldots \ldots \ldots \ldots \ldots \ldots \ldots \ldots . \ldots \ldots \ldots . \ldots \ldots$

3.3.2 Ceriodaphnia Toxicity Test Results - Survival ............ 3. 3.

3.3.3 Ceriodaphnia Toxicity Test Results - Reproduction .......... 3-5

3.3.4 Assessing Magnitude of Toxicity-Concentration - Response

Patterns for Ceriodaphnia .................... 3-5

3.3.5 Fathead Minnow Toxicity Test Results - Survival and Growth . . . 3-10

3.3.6 Ceriodaphnia and Fathead Minnow Tests of Tributary Sites

in Bear Creek . . . . . . . . . . . . . . . . . . . . . 


\section{CONTENTS (continued)}

Page

3.3.7 Longitudinal Patterns in Biological Quality of the Water in Bear Creek .......................... 3-15

3.3.8 Temporal Changes in Biological Quality of the Water in Bear Creek . . . . . . . . . . . . . . . . . . . 3-15

3.3.9 Presence of Snails (Elimia) in Upper Bear Creek . . . . . . . . . 3-15

3.3.10 Chemical Water-Quality Measurements . . . . . . . . . . . . . . 3-17



3.4.1 Longitudinal and Temporal Patterns in Ambient Toxicity ..... 3-17

3.4.2 Temporal Patterns in Chemical Water-Quality Conditions in Upper Bear Creek . . . . . . . . . . . . . . . . 3-17

3.5 CONCLUSIONS AND RECOMMENDATIONS $\ldots \ldots \ldots \ldots \ldots \ldots \ldots$

3.6 FUTURE STUDIES . . . . . . . . . . . . . . . . . 3-22

4. BIOACCUMULATION STUDIES (G. R. Southworth and $M$. J. Peterson) ... 4-1



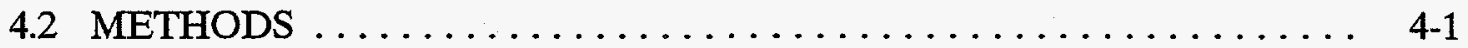

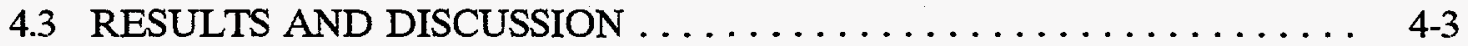

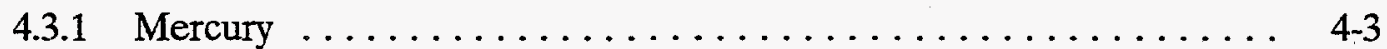

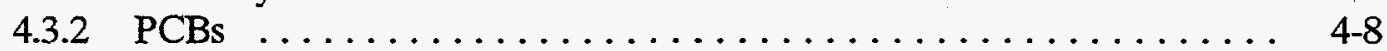

4.3.3 Contaminants in Forage Fish (Stonerollers) . . . . . . . . . . 4-11

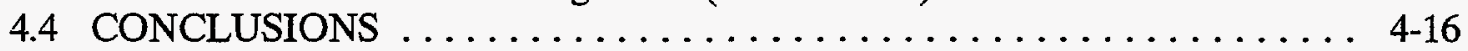

4.5 FUTURE STUDIES $\ldots \ldots \ldots \ldots \ldots \ldots \ldots \ldots \ldots \ldots \ldots \ldots \ldots \ldots \ldots$

5. INSTREAM ECOLOGICAL MONITORING (G. F. Cada, E. M. Schilling,

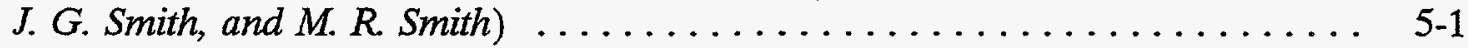

5.1 FISH COMMUNITY ASSESSMENT (E. M. Schilling) $\ldots \ldots \ldots \ldots \ldots \ldots$. $5-1$

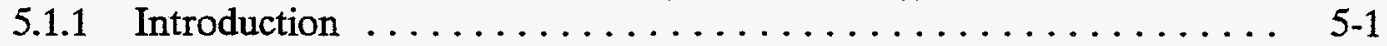

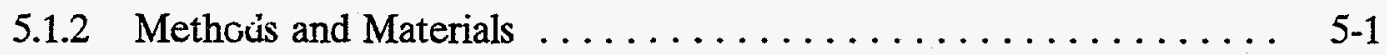

5.1.2.1 Field sampling procedures $\ldots \ldots \ldots \ldots \ldots \ldots \ldots \ldots \ldots$ 5-4

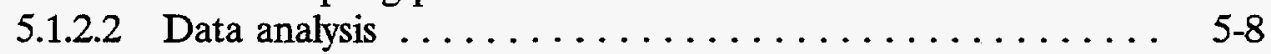

5.1 .3 Results and Discussion $\ldots \ldots \ldots \ldots \ldots \ldots \ldots \ldots \ldots \ldots \ldots \ldots$

5.1.3.1 Species richness and composition ............. $5-8$



5.1.3.3 Annual production . . . . . . . . . . . . . . 5-20

5.1 .4 Conclusions and Recommendations ................ 5-20

5.1 .5 Future Studies ........................ 5-24

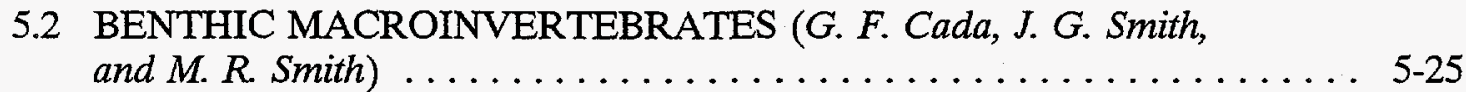



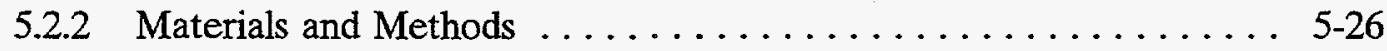






\section{CONTENTS (continued)}

\section{Page}

5.2.3.1 Taxonomic composition $\ldots \ldots \ldots \ldots \ldots \ldots \ldots \ldots, 5-30$

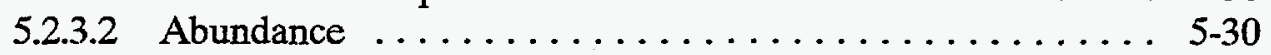

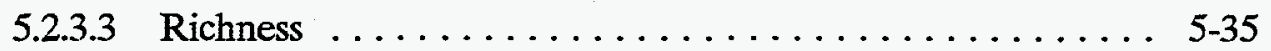

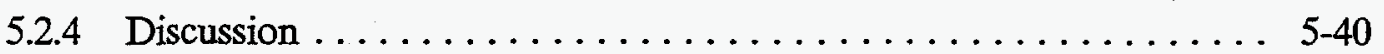

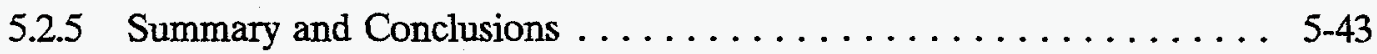

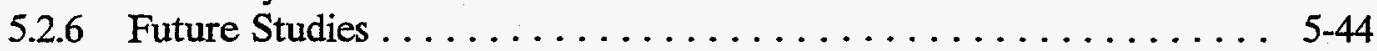

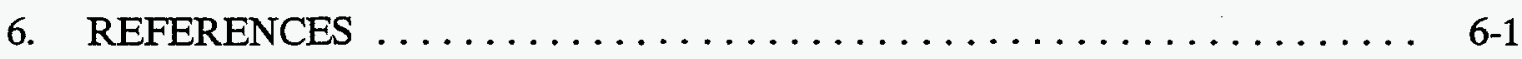

Appendix A: $\quad$ WATER QUALITY DATA FOR BEAR CREEK $\ldots \ldots \ldots \ldots$ A-1

Appendix B: DENSITY AND BIOMASS OF FISHES IN BEAR CREEK $\ldots . . \quad$ B-1

Appendix C: ANALYSIS OF STATISTICAL POWER FOR DIFFERENT

NUMBERS OF REPLICATES $\ldots \ldots \ldots \ldots \ldots \ldots \ldots \ldots, \mathrm{C}-1$

Appendix D: CHECKLIST OF BENTHIC MACROINVERTEBRATE TAXA

FROM BEAR CREEK APRIL 1985-APRIL 1993 .......... D-1

Appendix E: CHECKLIST OF BENTHIC MACROINVERTEBRATE TAXA

FROM BEAR CREEK REFERENCE SITES,

APRIL 1985-APRIL $1993 \ldots \ldots \ldots \ldots \ldots \ldots \ldots \ldots \ldots$ E-1

Appendix F: $\quad$ EVALUATION OF BEAR CREEK KILOMETER $0.70 \ldots \ldots \quad$ F-1

Appendix G: BEAR CREEK BENTHIC MACROINVERTEBRATE

REFERENCE SITE SIZE DIFFERENTIAL

EVALUATION 



\section{FIGURES}

Figure

Page

2.1 Daily discharge in Bear Creek at USGS gaging station 1985 through $1994 \ldots 2-4$

2.2 Precipitation measured at the Atmospheric Turbulence and Diffusion

2.3 Mean monthly temperatures at Bear Creek kilometers 7.87, 9.40, 9.91, and 11.98, and at Grassy Creek kilometer 2.4, 1988-90

2.4 Mean monthly temperatures at Bear Creek kilometers 7.87, 9.40, 9.91, and 11.98, and at Grassy Creek kilometer 2.4, and at Gum Hollow Creek kilometer 1.9, 1991-93

3.1 Location of toxicity testing sampling sites $\ldots \ldots \ldots \ldots \ldots \ldots \ldots \ldots \ldots \ldots$

3.2 Concentration-response curves for Ceriodaphnia survival and reproduction in water from Bear Creek kilometer 12.36 during March 1990 . . . . . . . . . 3-11

3.3 Temporal changes in location of the "toxic threshold" position in upper Bear Creek . . . . . . . . . . . . . . . . . . . . . . . . . . . . 3-16

3.4 Coefficients of variation for hardness and conductivity for water samples from various sites in Bear Creek . . . . . . . . . . . . . . 20

4.1 Location of bioaccumulation sampling sites $\ldots \ldots \ldots \ldots \ldots \ldots \ldots \ldots \ldots$ 4-2

4.2 Location of reference streams for the bioaccumulation task $\ldots \ldots \ldots \ldots \ldots$. . . 4

4.3 Mean concentration of mercury $( \pm \mathrm{SE}, n=8)$ in rock bass at $\mathrm{BCK} 0.6$



4.4 Mean mercury concentrations in rock bass (Ambloplites rupestris) from lower Bear Creek (kilometer 0.6) 1988-93

4.5 Mean concentrations of polychlorinated biphenyls (PCBs) in rock bass

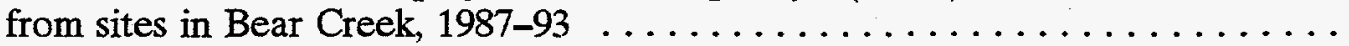

4.6 Mean concentrations of polychlorinated biphenyls (PCBs) in caged clams and resident fish from Bear Creek kilometer 4.5 


\section{FIGURES (continued)}

Figure

4.7 Mean concentrations of mercury and nickel in whole stonerollers from Bear Creek and Hinds Creek . . . . . . . . . . . . . . . . . 4-13

4.8 Mean concentrations of uranium and cadmium in whole stonerollers from Bear Creek and Hinds Creek . . . . . . . . . . . . . . . . . . . 4-14

4.9 Mean concentrations of polychlorinated biphenyls (PCBs) and lithium in whole stonerollers from Bear Creek and Hinds Creek . . . . . . . . 4 4-15

$5.1 \quad$ Location of fish community study sampling sites $\ldots \ldots \ldots \ldots \ldots \ldots$

5.2 Location of reference sites for the fish community task $\ldots \ldots \ldots \ldots \ldots-3$

5.3 Total estimated fish density in Bear Creek, spring 1988-fall $1993 \ldots$. . . . 5-15

5.4 Total estimated fish density in Bear Creek, spring 1988-fall $1993 \ldots$. . . . 5-15

5.5 Total estimater fish density in Mill Branch, Grassy Creek, Gum Hollow Creek, and Pinhook Branch, spring 1988-fall 1993 . . . . . 5 5-16

5.6 Total estimated fish biomass in Bear Creek, spring 1988-fall $1993 \ldots \ldots$. . . 5-16

5.7 Total estimated fish biomass in Bear Creek, spring 1988-fall $1993 \ldots$. . . . 5 5-17

5.8 Total estimated fish biomass in Mill Branch, Grassy Creek, Gum Hollow Creek, and Pinhook Branch, spring 1988-fall 1993 . . . . . 5 5-17

5.9 Total estimated Tennessee dace density in Bear Creek,

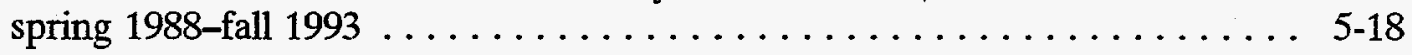

5.10 Total estimated Tennessee dace density in Bear Creek,

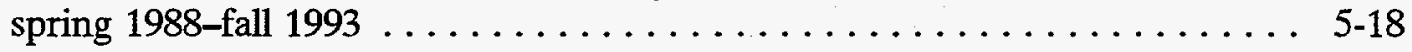

5.11 Location of benthic macroinvertebrate community study sampling sites $\ldots \quad \ldots-27$

5.12 Location of reference sites for the benthic macroinvertebrate community task

5.13 Mean total conmunity densities of the benthic macroinvertebrate at sites in Bear Creek, Grassy Creek, Gum Hollow Branch, Mill Branch, and U.T. Farm Creek in April of each year, $1985-93 \ldots \ldots \ldots \ldots \ldots$. . . . . . . . . . 


\section{FIGURES (continued)}

Figure

Page

5.14 Mean percent composition (i.e., mean percentage of total density) of selected benthic macroinvertebrates taxonomic groups in April samples at sites in Bear Creek, 1985-93

5.15 Mean densities of Ephemeroptera, Plecoptera, and Trichoptera in April samples at sites in Bear Creek, 1985-93

5.16 Mean percent composition (i.e., mean percentage of total density) of selected benthic macroinvertebrate taxonomic groups in April samples at sites in Grassy Creek, Gum Hollow Branch, Mill Branch, and U.T. Farm Creek, 1985-93.

5.17 Mean densities of Ephemeroptera, Plecoptera, and Trichoptera in April samples at sites in Grassy Creek, Gum Hollow Branch, Mill Branch, and U.T. Farm Creek, 1985-93.

5.18 Mean total richness of the benthic macroinvertebrate communities at sites in Bear Creek, Grassy Creek, Gum Hollow Branch, Mill Branch, and U.T. Farm Creek in April of each year, 1985-93

5.19 Mean richness of Ephemeroptera, Plecoptera, and Trichoptera (i.e. EPT richness) at sites in Bear Creek, Grassy Creek, Gum Hollow Branch, Mill Branch, and U.T. Farm Creek in April of each year, 1985-93 . 



\section{TABLES}

Table

Page

2.1 Location of the biological monitoring sites (by task) on Bear Creek ......

2.2 Chronological summary of major events in the Bear Creek Valley

Operable Units that may have affected water quality in Bear Creek and its tributaries

3.1 Toxicity testing in Bear Creek, March 1, 1990, through August 4, $1994 \ldots$

3.2 Results of fathead minnow and Ceriodaphnia tests of ambient water samples from various sites in Bear Creek . .................

3.3 Distribution of Ceriodaphnia survival values for ambient toxicity tests of water from six sites in Bear Creek (March 1, 1990, through May 26, 1994) . .

3.4 Mean reproduction of Ceriodaphnia in ambient toxicity tests of water from Bear Creek (March 1, 1990, through May 26, 1994) .............

3.5 Results of Duncan's Multiple Range Test applied to ANOVAs for both full and date-pruned data sets for Ceriodaphnia reproduction . . . . . . . . .

3.6 Results of two-way ANOVAs for fathead minnow survival (arc-sine square-root transformed percentage) with data for controls included (left) and excluded (right) $\ldots \ldots \ldots \ldots \ldots \ldots \ldots \ldots \ldots \ldots \ldots \ldots$

3.7 Results of two-way ANOVAs for fathead minnow growth with data for controls included (left) and excluded (right) $\ldots \ldots \ldots \ldots \ldots \ldots \ldots \ldots$

3.8 Fathead minnow survival and mean growth and Ceriodaphnia survival and mean reproduction in water from various sites in Bear Creek (including tributaries) and reference sites for 7-d tests conducted during May 19-26, 1994

3.9 Fathead minnow survival and mean growth and Ceriodaphnia survival and mean reproduction in water from various sites in Bear Creek (including tributaries) and reference sites for $7-\mathrm{d}$ tests conducted during August $4-10,1994 \ldots \ldots \ldots \ldots \ldots \ldots \ldots \ldots \ldots$

3.10 Summary statistics of water quality factors for Bear Creek ambient toxicity testing sites 


\section{TABLES (continued)}

Table

Page

3.11 Mean (coefficient of variation) levels of conductivity, alkalinity, and hardness for water samples from various sites in selected streams on the Oak Ridge Reservation . . . . . . . . . . . . . . . . . .

3.12 Levels of calcium in relation to nitrate, alkalinity, and conductivity in BCK 11.97-11.83 . . . . . . . . . . . . . . . . . . . . . .

3.13 Levels of calcium in relation to nitrate, alkalinity, and conductivity in BCK 12.4-12.36

4.1 Mean concentrations ( \pm 1 SE) of mercury and PCBs in filets of rock bass (Ambloplites rupestris) and redbreast sunfish (Lepomis auritus) from Bear Creek ( $n=8$ at BCK 0.6, $n=4$ at BCK 4.5), and mean concentrations of PCBs in duplicate composite samples of caged clams (Corbicula fluminea)



4.2 Mean ( \pm SE) concentrations of metals and polychlorinated biphenyls (PCBs) in stonerollers (Campostoma anomalum) from Bear Creek, June 1994

5.1 Length, mean width, mean depth, surface area, and pool to riffle ratio of fish sampling sites in Bear Creek and the reference streams, Grassy Creek, Gum Hollow, Mill Branch, and Pinhook Branch, for spring and fall

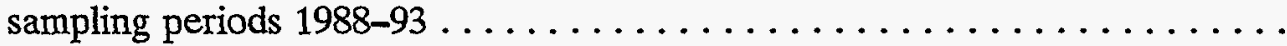

5.2 Fish species composition in Bear Creek and in four reference streams; Gum Hollow Creek, Pinhook Branch, Grassy Creek, and Mill Branch, for March through May 1988-93 and October through December 1988-93 ....

5.3 Total fish density (number of fish per square meter), total biomass (grams of fish per square meter), and species richness in Bear Creek and in four reference streams, Gum Hollow Creek, Pinhook Branch, Grassy Creek, and Mill Branch, for March through May, 1988-93 and October through December, 1988-93

5.4 Annual production rates in Bear Creek and in two reference streams, Grassy Creek and Mill Branch, for spring 1988 through 1993

5.5 Annual production rates of fish communities in warmwater streams in the southeastern United States 


\section{TABLES (continued)}

Table

Page

5.6 F-values and $p$-values for two-way analysis of variance (ANOVA) and regression analysis (testing for equal slopes across sites) using the response variables density, total richness, and EPT richness for Bear Creek and five reference sites, April sampling period only, 1988-93 


\section{LIST OF ACRONYMS}

\begin{tabular}{|c|c|}
\hline ANOVA & analysis of variance \\
\hline ASO & Analytical Services Organization \\
\hline ATDL & Atmospheric Turbulence and Diffusion Laboratory \\
\hline $\mathrm{BCK}$ & Bear Creek kilometer \\
\hline $\mathrm{BG}$ & burial ground \\
\hline BMAP & Biological Monitoring and Abatement Program \\
\hline BMP & Biological Monitoring Program \\
\hline CERCLA & $\begin{array}{l}\text { Comprehensive Environmental Response, Compensation, and Liability Act } \\
\text { of } 1980\end{array}$ \\
\hline COPC & containment of potential concern \\
\hline CV & coefficient of variation \\
\hline CWA & Clean Water Act \\
\hline DCG & derived concentration value(s) \\
\hline DOE & U.S. Department of Energy \\
\hline EFK & East Fork Poplar Creek kilometer \\
\hline EFPC & East Fork Poplar Creek \\
\hline EPA & Environmental Protection Agency \\
\hline EPT & Ephemeroptera, Plecoptera, and Trichoptera \\
\hline ESD & Environmental Sciences Division \\
\hline ESF & Environmental Support Facility \\
\hline EDTA & ethylene diamine tetra-acetic acid \\
\hline FDA & U.S. Department of Agriculture Food and Drug Administration \\
\hline GC/ECD & gas chromatography/electron capture detection \\
\hline GCK & Grassy Creek kilometer \\
\hline GHK & Gum Hollow Creek kilometer \\
\hline $\mathrm{HCDA}$ & Hazardous Chemical Disposal Area \\
\hline ICP & inductively coupled plasma \\
\hline MBK & Mill Branch kilometer \\
\hline NOAA & National Oceanic and Atmospheric Administration \\
\hline NOEC & no-observed effect concentration \\
\hline NPDES & National Pollutant Discharge Elimination System \\
\hline NT & north tributary \\
\hline ORNL & Oak Ridge National Laboratory \\
\hline ORP & oil refined pond \\
\hline ORR & Oak Ridge Reservation \\
\hline OU & Operable unit \\
\hline PCB & polychlorinated biphenyl \\
\hline PHK & Pinhook Branch kilometer \\
\hline RCRA & Resource Conservation and Recovery Act \\
\hline RSA & rust spoil area \\
\hline
\end{tabular}


QA quality ássurance

SAS

Statistical Analysis System

SL sanitary landfill

$\mathrm{SR}_{15}$

SS

Standard Reproduction Value of 15 offspring/female

ST south spring

SY south tributary

TDEC

TVA spoil yard

USGS

Tennessee Department of Environment and Conservation

Tennessee Valley Authority

UTK

U.S. Geological Survey

University of Tennessee Farm Creek kilometer 


\section{ACKNOWLEDGMENTS}

Special thanks to Aquatic Toxicology Laboratory staff for conducting the toxicity tests reported here: these people include B. K. Beane, P. W. Braden, L. S. Ewald, L. A. Kszos, K. J. McAfee, G. W. Morris, T. L. Phipps, W. S. Session, and J. R. Sumner. We thank all those individuals who assisted with the field sampling, including B. A. Carrico, B. F. Clark, W. C. Dickerson, D. K. Cox, C. E. Duncan, W. M. Harris, R. P. Hoffmeister, R. H. Hull, W. C. Kyker, A. W. McWhorter, D. L. Morgan, W. K. Roy, M. G. Ryon, G. Saylor, W. H. Schacher, L. M. Stubbs, D. K. Weaver, W. S. Wilkerson and J. A. Wojtowicz. We are grateful to the following reviewers for their insightful comments; Mark Bevelheimer, Don Jones, George Southworth, and John Trabalka. This document was greatly improved as a result of their efforts. Finally, thanks to J. L. Beauchamp for statistical help,

E. B. Bryant for editorial support, L. J. Jennings and P. L. Henry for electronic publishing of this document.

This work was funded by the Environmental Restoration Program of the Oak Ridge Y-12 Plant. The Y-12 Plant is managed by Lockheed Martin Energy Systems, Inc., and Oak Ridge National Laboratory is managed by Lockheed Martin Energy Research Corp. for the U.S. Department of Energy under contract number DE-AC05-96OR22464. 



\section{EXECUTIVE SUMMARY}

The Bear Creek Valley watershed drains the area surrounding several closed Oak Ridge Y-12 Plant waste disposal facilities. Past waste disposal practices in the Bear Creek Valley resulted in the contamination of Bear Creek and consequent ecological damage (Southworth et al. 1992). The Biological Monitoring Program (BMP) for the Bear Creek watershed was initiated in May 1984. Early biological monitoring of Bear Creek involved analysis of the fish and benthic invertebrate communities at selected study sites distributed along the length of the stream. A bioaccumulation task was added to the ongoing monitoring program in 1987. In 1994, 14 sites were tested in addition to the 6 sites routinely tested for toxicity as part of the Bear Creek Valley Ecological Risk Assessment. The goals for the Bear Creek BMP are to (1) identify and prioritize contaminant sources and (2) assess the effectiveness of remedial actions. To accomplish Objective 1, studies were conducted to characterize the existing environment in Bear Creek. The results of these studies are described in Southworth et al. (1992). Following the characterization phase, long-term monitoring studies were initiated to address Objective 2. The results of sampling conducted from May 1984 through early 1989 are presented in Southworth et al. (1992). Monitoring activities conducted from 1989 through spring 1994 are presented in this report.

Bear Creek was found to contain adequate physical habitat to maintain and propagate aquatic life throughout its length, with the lower reaches having increased habitat diversity as is typical of most streams (Southworth et al. 1992). The hydrology of Bear Creek and its tributaries reflects the underlying geology of the watershed. Flow in Bear Creek closely follows precipitation patterns. Average flow for 1985 through October 1994 was $202 \mathrm{~L} / \mathrm{s}$. Average flow from 1985 through 1991 was $200 \mathrm{~L} / \mathrm{s}$. Average flow from 1991 through October 1994 was $249 \mathrm{~L} / \mathrm{s}$. The lowest annual mean occurred in $1988(73 \mathrm{~L} / \mathrm{s})$, and the highest annual mean occurred in $1990(312 \mathrm{~L} / \mathrm{s})$. Precipitation was $109 \%, 111 \%, 81 \%$, and $91 \%$ of normal in 1990,1991, 1992, and 1993 respectively. Precipitation in the first quarter of 1994 is well above normal (approximately 150\%) as is flow (mean of $434.81 \mathrm{~L} / \mathrm{s}$ for January through October; approximately $215 \%$ of normal).

The effects of facility effluents on the natural receiving waters are assessed though the ORR surface water monitoring program. Surface water in the Bear Creek watershed is affected by surface and subsurface drainage from waste burial grounds, the Oil Landfarm, seepages from the S-3 Pond area, construction-related disturbances, and several large springs. As a general summary, water quality in Bear Creek was characterized by (1) high concentrations of dissolved salts resulting from the infiltration of contaminated groundwater in the vicinity of the S-3 Ponds; (2) elevated concentrations of some trace ions in the upper reaches of Bear Creek, but declining to about background levels or below detection limits within a short distance downstream; (3) elevated levels of metals in the sediments in the upper stream reaches; (4) elevated levels of volatile organic compounds entering 
Bear Creek through north tributaries (NT) 7 and 8; and (5) the presence of polychlorinated biphenyls (PCBs) in the sediments and biota. Concentrations of cadmium, chromium, copper, lead, mercury, selenium, silver, and PCBs have exceeded the Tennessee Water Quality Criteria from 1990 though 1994 for Bear Creek

kilometers (BCK) 11.97 and 12.4; however, in many cases the analytical detection limit of the parameter was higher than the reference value. Conservative water quality parameters measured as part of the toxicity monitoring task showed that mean levels of hardness and conductivity were high compared with those reported for other chemically perturbed streams on ORR. In the $1970 \mathrm{~s}, \mathrm{pH}$ values ranged from 3.5-6.8 over a 5-month period (ERDA 1975). Within several months of neutralization of the S-3 Ponds, $\mathrm{pH}$ levels rose to more than 7.0 (Southworth et al. 1992). From 1990 though 1994, $\mathrm{pH}$ values have ranged from 6.7 to 8.8 , which is within the Tennessee Water Quality Standard reference values for this parameter. High levels of aluminum (more than $100 \mathrm{ppm}$ ) were noted in the acidified waters prior to 1983 (Southworth et al. 1992). Mean concentrations of aluminum in the 1990-94 period have been below $67 \mathrm{ppm}$ and have rarely exceeded $100 \mathrm{ppm}$. Concentrations of other metals also decreased (EAD 1984) as did levels of nitrates, conductivity, and calcium. These improvements in overall water quality may help explain the recolonization of the upper reaches of Bear Creek by fish and benthic macroinvertebrate communities.

In addition to the conventional water quality parameters monitored at these site, radiological monitoring is also conducted at BCK 11.97 and 12.4. All radiological results were well below the derived concentration values (DCGs) listed in U.S.
Department of Energy (DOE) Order 5400.5 for both sites, with ${ }^{237} \mathrm{~Np}$ being the only radionuclide exceeding $2 \%$ of a DCG (3.77\% and $2.35 \%$ at BCK 11.97 and 12.4 respectively) (Kornegay et al. 1993). Bear Creek kilometer 4.55, also designated as National Pollutant Discharge Elimination System (NPDES) outfall 304, is also monitored for radiological parameters. All radiological results were well below DCGs at this location.

Continuous monitoring of instream water temperature has been ongoing at three Bear Creek sites (BCK 7.87, 9.40, and 9.91) since 1985 (Southworth et al. 1992). A fourth site, BCK 11.98 , has been monitored since April 1987. With one notable exception, no Bear Creek or reference stream site had temperatures in excess of $30^{\circ} \mathrm{C}$ during the period of record (January 1988-December 1993).

Tests with fathead minnow larvae and Ceriodaphnia were conducted to estimate acute and chronic toxicity of water from various sites in Bear Creek. A failurefrequency analysis showed that Ceriodaphnia mortality was greater than might be expected based on chance alone at BCK 11.09, 11.83, and 12.36: this outcome provided evidence for acute toxicity at these sites. Evidence for chronic toxicity was found at BCK 12.36 and 11.83 , and perhaps at BCK 9.91, based on Ceriodaphnia reproduction. Analysis of fathead minnow survival and growth data showed that date effects were greater than site effects for both factors. Thus, the minnow tests did not provide compelling evidence for either acute or chronic toxicity at any of the sites. Evaluation of water-quality parameters (including $\mathrm{pH}$, conductivity, alkalinity, and hardness) suggested that calcium concentrations in upper Bear Creek could be great enough and variable enough to account for toxicity 
to Ceriodaphnia at BCK 12.36 and 11.83. Calcium concentrations are declining both at BCK 12.36 and 11.83 , but at different rates. Because nitrate levels are declining more rapidly than calcium (due perhaps to its greater rate of mobility through groundwater or soil, or perhaps due to continued losses by denitrification), the calcium-supporting anionic system previously dominated by nitrate should shift to domination by (bicarbonate + carbonate). The switch in chemical control over calcium, from nitrate to (bicarbonate + carbonate), is predicted to importantly affect cycling patterns of other metals in the stream and hasten additional improvements in water-quality conditions. Future studies were targeted to assess this prediction. Casual observations showed that Elimia clavaeformis (a snail common in many streams on the Oak Ridge Reservation) is re-invading headwater segments of Bear Creek. The recolonization of upper segments of this stream by Elimia could provide strong support for the idea that biological recovery is in progress. A semiquantitative survey to document the distribution and abundance of Elimia in Bear Creek (and its tributaries) is proposed as a means to document ecological recovery of the stream.

Mercury contamination in rock bass in lower Bear Creek has been steadily increasing, with no apparent source or cause, since 1987. A pronounced seasonal cycle is also evident, with mean concentrations in fish increasing over the summer/fall and decreasing during winter/spring. A downstream gradient in mercury in fish is not evident, but its absence may be an artifact of habitat limitation. NPDES monitoring data at BCK 11.95 does not consistently detect mercury contamination. High sensitivity analyses of aqueous mercury concentrations in Bear Creek are needed to help ascertain the location and magnitude of the source of mercury contamination in fish.

PCB contamination is present in fish in Bear Creek, but it appears to have been reduced by remedial actions targeted at eliminating inputs to the creek from burial ground seeps and oil retention ponds. PCB contaminated soils remain in the creek floodplain, and accumulations of PCB contaminated sediments no doubt still occur at localized sites within the creek. Periodic high concentrations of PCBs in fish at BCK 4.5 may be related to seasonal or weather related variation in sediment transport and erosion. Mean PCB concentrations in rock bass are below the U.S. Department of Agriculture Food and Drug Administration (FDA) tolerance level but exceed Comprehensive Environmental Response, Compensation, and Liability Act risk-based criteria.

Nineteen species of fish were found in quantitative sampling of the fish community in Bear Creek by electofishing biannually from spring 1988 through fall 1993. The predominant fish species upstream of the weir at BCK 4.55 included the central stoneroller (Campostoma anomalum), Tennessee dace (Phoxinus tennesseensis), blacknose dace (Rhinichthys atratulus), and creek chub (Semotilus atromaculatus). The sites downstream of the weir were more diverse because the weir acts as a barrier to the upstream migration of fish. The sites downstream of the weir were represented by these common species but also contained spotfin shiner (Cyprinella spiloptera), rosefin shiner (Lythrurus ardens), bluntnose minnow (Pimephales notatus), northern hog sucker (Hypentelium nigricans), rockbass (Ambloplites rupestris), stripetail darter 
(Etheostoma kennicotti), snubnose darter (E. simoterum), and logperch (Percina caprodes).

Improvements in the fish populations were observed at the two uppermost sites. Significant increases occurred in fish population density, biomass, and total production at BCK 12.36 from 1988 through 1993. These changes are undoubtedly related to improvement in water quality following the closure of the S-3 Ponds.

One important aspect of the fish fauna of Bear Creek above the weir is the distribution and abundance of the Tennessee dace. The Tennessee dace is listed as a species "deemed in need of management" by the Tennessee Wildlife Resources Agency, and its habitat is protected (Starnes and Etnier 1980). In Tennessee, the largest populations of Tennessee dace occur in the Cherokee National Forest, Polk County, and on the Oak Ridge Reservation in Roane and Anderson counties. ORR may offer a stronghold for the Tennessee dace (Etnier and Starnes 1993).

The benthic macroinvertebrate community of Bear Creek has been evaluated at seven sites with a quantitative sampling program since May 1984. Results of samples that have been collected in each April sampling period through 1993 indicate the presence of a degraded macroinvertebrate community in Bear Creek. During this 9-year study period, the macroinvertebrate community exhibited evidence of maximal impact in the reaches of Bear Creek nearest to the S-3 Pond site. Improvements were evident with increasing distance from the Y-12 Plant, as was shown by gradual increases in total richness and richness of the Ephemeroptera, Plecoptera, and Trichoptera (EPT richness). Full recovery was evident at the most downstream site in Bear Creek (i.e., BCK 3.25). The absence or presence of only small numbers of mayflies (Ephemeroptera) at all sites except BCK 3.25 suggests that the major cause of impact to the macroinvertebrate community may be the presence of metals. Other factors such as siltation/ sedimentation and the possible presence of additional toxicants (e.g., elevated concentrations of some ions and metals) may also be impacting the invertebrate community in Bear Creek.

Although the macroinvertebrate community exhibited strong evidence of impact upstream to BCK 3.25 , some recovery has occurred since 1987. Substantial increases have occurred in richness and density upstream to BCK 12.36 , particularly since 1988 . It is not clear yet whether the recovery exhibited by the macroinvertebrate community was associated with remedial actions or changes in natural environmental conditions (e.g., increased rainfall resulting in a dilution effect of toxicants), or both.

During the 1980 s, the Y-12 Plant began terminating disposal activities at many of the disposal sites and initiated remedial actions in the Bear Creek Valley. Biological monitoring activities in Bear Creek indicate that recovery of the biotic community, while not complete, has begun in response to those remedial actions. Water quality monitoring indicates reductions in metals, conductivity, and calcium, and an increase in $\mathrm{pH}$, especially in the upper reaches of stream that were affected by the S-3 Ponds. Concentrations of PCBs in fish have been reduced by remedial action activities. Toxicity to fathead minnows has been reduced at all sites, and toxicity to Ceriodaphnia has been reduced at the lower sites. There have 
been improvements in both the fish and benthic macroinvertebrate communities, especially at the uppermost sites. However, recovery is not complete. Water from upper Bear Creek is still toxic to Ceriodaphnia. Mercury contamination in fish in lower Bear Creek is steadily increasing, with no apparent source or cause. While improvements have occurred in the benthic macroinvertebrate and fish communities, neither have achieved levels seen in reference streams.

Recovery is expected to continue with further remediation and/or changes in natural conditions. 



\title{
1. INTRODUCTION
}

\author{
R. L. Hinzman and G. R. Southworth
}

\subsection{INTRODUCTION}

The Bear Creek Valley watershed drains the area surrounding several closed Oak Ridge Y-12 Plant waste disposal facilities. Past waste disposal practices in the Bear Creek Valley resulted in the contamination of Bear Creek and consequent ecological damage (Southworth et al. 1992). Ecological monitoring by the Biological Monitoring and Abatement Program (BMAP) was initiated in the Bear Creek watershed in May 1984 and continues at present. Studies conducted during the first year provided a detailed characterization of the benthic invertebrate and fish communities in Bear Creek. The initial characterization was followed by a biological monitoring phase in which studies were conducted at reduced intensities.

Studies in the Bear Creek watershed were designed to meet two primary objectives: to (1) assist in the development of an effective remedial action plan related to past waste disposal operation in Bear Creek Valley and (2) evaluate the effectiveness of these actions by monitoring the ecological recovery of Bear Creek. To accomplish Objective 1, studies were conducted to characterize the existing environment in Bear Creek. The results of these studies are described in Southworth et al. (1992). Following the characterization phase, long-term monitoring studies were initiated to address Objective 2. The results of sampling conducted from May 1984 through early 1989 are presented in Southworth et al. (1992). Monitoring activities conducted from 1989 through spring 1994 are presented in this report.

The Biological Monitoring Program in Bear Creek consists of three major tasks that reflect different but complementary approaches to evaluating the effects of Y-12 Plant remedial actions on the ecological integrity of Bear Creek. These tasks include (1) toxicity testing, (2) bioaccumulation studies, and (3) instream monitoring of the benthic invertebrate and fish communities. The monitoring program uses a variety of approaches including laboratory studies, manipulative field experiments, and direct instream sampling of biota to identify causal mechanisms underlying the observed effects.

In addition, biological monitoring conducted by the BMAP will be used to support an ecological risk assessment for the Bear Creek Valley. Special studies, including soil toxicity testing, sediment toxicity testing, and terrestrial ecological monitoring will be conducted in addition to routine monitoring activities and will be essential in the success of this effort. 


\title{
2. DESCRIPTION OF BEAR CREEK WATERSHED
}

\author{
R. L. Hinzman, W. K Roy, and G. R. Southworth
}

\subsection{DESCRIPTION OF STUDY AREA}

The Bear Creek watershed lies within the boundaries of the Oak Ridge Reservation (ORR) in Roane and Anderson counties. The watershed has a drainage area of $18.52 \mathrm{~km}^{2}\left(7.15 \mathrm{~m}^{2}\right)$ (Earthinfo, Inc. 1992) and contains no privately owned lands. The stream originates near the S-3 Waste Management Area within the boundaries of the Oak Ridge Y-12 Plant. The Y-12 Plant is situated at the eastern end of ORR, adjacent to the commercial center of Oak Ridge and contains about 324 ha. The Bear Creek Valley is bounded to the north by Pine Ridge and to the south by Chestnut Ridge. Elevations in the watershed range from $230 \mathrm{~m}$ at the mouth of the stream to $372 \mathrm{~m}$ at the crest of Chestnut Ridge. The Y-12 Plant is located on the headwater divide between Bear Creek, which flows to the west of the plant, and East Fork Poplar Creek (EFPC), which flows to the east of the plant. The stream flows about $12.9 \mathrm{~km}$ before joining EFPC at kilometer (EFK) 2.6. The average gradient at Bear Creek kilometer (BCK) 12.8 is $5.6 \mathrm{~m} / \mathrm{km}$.

\subsection{STUDY SITES}

Early biological monitoring of Bear Creek involved analysis of the fish and benthic invertebrate communities at selected study sites distriouted along the length of the stream. These sites were selected to minimize the physical differences in habitat that could influence the structure of biological communities. Habitat characterizations were conducted for the fish and benthic macroinvertebrate sites in June 1988 and included measurements of stream flow, substrate, bank cover and canopy, and the pool-toriffle ratio. The results of the habitat study are presented in Southworth et al. (1992). Despite efforts to match similar habitat variables at all study sites, there were substantial differences among sites due to the longitudinal gradient in the physical habitat that is characteristic of streams. Major differences in most physical habitat parameters were observed between upper and lower Bear Creek. Fish species diversity and abundance have been shown to vary as a function of some of the habitat characteristics that differ between upper and lower Bear Creek, such as the amount of siltation and the frequency of no-flow conditions (Foltz 1982). However the similarity of habitat between Bear Creek and the reference streams can be used to identify temporal changes in fish species abundance and richness that are associated with remedial actions implemented at the Y-12 Plant (Southworth et al. 1992). Multiple reference streams were selected to reflect the range of habitats in Bear Creek.

General sampling locations for the Biological Monitoring Program (BMP) are discussed in Table 2.1. There are maps showing the location of sampling sites by task along with a description of each task in each of the following chapters. Many tasks share sites to maintain consistency in the data. Sites BCK 9.4 and 9.9 are located just downstream of north tributaries (NT) 8 and 7, which drain the Y-12 Burial Grounds. Site BCK 11.1 is located downstream from NT-4, which drains the Sanitary Landfill. 
Table 2.1. Location of the biological monitoring sites (by task) on Bear Creek

\begin{tabular}{|c|c|c|c|c|}
\hline \multirow[b]{2}{*}{ Site } & \multicolumn{4}{|c|}{ Task } \\
\hline & Toxicity testing & Bioaccumulation & $\begin{array}{c}\text { Benthic } \\
\text { invertebrate }\end{array}$ & Fish community \\
\hline BCK 0.6 & & $\mathrm{X}$ & & \\
\hline $\mathrm{BCK}, 0.7$ & & & & $\mathrm{x}$ \\
\hline BCK 3.25 & & & $\mathrm{X}$ & $\mathrm{X}$ \\
\hline \multicolumn{5}{|l|}{ BCK 3.5} \\
\hline BCK 4.5 & & $\mathrm{X}$ & & \\
\hline \multicolumn{5}{|l|}{ BCK 6.87} \\
\hline BCK 7.87 & $\mathrm{X}$ & & $X$ & $\mathrm{X}$ \\
\hline BCK 9.4 & $\mathrm{X}$ & & $\mathrm{X}$ & $\mathrm{X}$ \\
\hline BCK 9.9 & $\mathrm{X}$ & & $\mathrm{X}$ & $\mathrm{X}$ \\
\hline BCK 11.0 & & & $X$ & $\mathrm{X}$ \\
\hline BCK 11.1 & $\mathrm{X}$ & & & \\
\hline BCK 11.8 & $X$ & & $\mathrm{X}$ & $\mathrm{X}$ \\
\hline \multicolumn{5}{|l|}{ BCK 12.0} \\
\hline BCK 12.3 & $X$ & & $X$ & $\mathrm{X}$ \\
\hline
\end{tabular}

Note: $\mathrm{BCK}=$ Bear Creek kilometer.

As part of the Bear Creek Valley Ecological Risk Assessment, a one time sampling of 14 sites was done in addition to the 6 sites routinely tested for toxicity. These sites included NT 1-8; South Springs (SS) 1, 4, 5, 6, ard 8; and BCK 3.25. These sites were chosen to bracket discharges/seepages from the waste disposal areas (see Section 2.4). Five sites which bracket and/or are located downstream of the waste areas were selected for the bioaccumulation task. Bear Creek kilometer 0.7 was added as a quantitative fish sampling site beginning in spring 1993. Sampling at this site was initiated to monitor any adverse effects from runoff from the White Wing Scrapyard to Bear Creek.
A variety of streams served as reference sites, depending on the requirements of the task. The methods and materials section for each task generally describes the reference sites used for that task. In general, reference sites are selected that are relatively unimpacted (e.g., they receive no significant discharges that may affect water quality) and have similar streamflow, drainage area, and habitat as Bear Creek. Because unimpacted reference sites that meet all of the criteria are not available, many tasks use multiple reference sites (e.g., caged clam studies, Sect. 4.1, and benthic macroinvertebrate community studies, Sect. 5.2.2) to strengthen their interpretation of statistical results, or to 
demonstrate multiple lines of evidence for effects, or lack thereof. Maps showing sampling locations at reference sites are included in each task description.

\subsection{GEOHYDROLOGY}

The Bear Creek Valley is located within the Valley and Ridge physiographic province and is underlain by Cambrian limestones, shales, and siltstones of the Conasauga Group. The Maynardville limestone in the upper part of this group contains numerous solution cavities. Bear Creek Valley is bounded to the north by Pine Ridge, which is composed of sandy shales and sandstones of the Rome Formation, and to the south by Chestnut Ridge, which is underlain by siliceous dolomite of the Knox Group. The Knox Dolomite is the major aquifer in the Oak Ridge area, and the shales and sandstones of the Rome formation are among the poorest water-bearing formations (McMaster 1967). Extensive summaries of geology and hydrology of the Bear Creek Valley can be found in SAIC (1994).

The hydrology of Bear Creek and its tributaries reflects the underlying geology of the watershed. The main stem of Bear Creek above the U.S. Geological Survey (USGS) gauging station at BCK 4.55 is characterized by reaches of stream where flow is lost to the solution-cavity systems (Southworth et al. 1992). A major losing reach is between the burial grounds and oil landfarm near BCK 10.41, and another is located just upstream of BCK 4.70 . Periods of no flow are common in Bear Creek near BCK 10.41 but occur less frequently near BCK 4.70 (Table 2.7 in Southworth et al. 1992). The north tributaries of Bear Creek above SS-5, especially NT 3, 4, 5 and 6, drain portions of Pine Ridge; these streams are intermittent and usually dry during summer and early fall. The south tributaries (ST), however, originate as springs in the Knox Dolomite of Chestnut Ridge and are perennial streams. The numerous springs that originate on the north slope of Chestnut Ridge are a dominant feature of the Bear Creek hydrograph, especially during drought periods. At such times, most of the flow in the main stem of Bear Creek is contributed by springs (Southworth et al. 1992). For a more detailed description of the geology of Bear Creek Valley the reader is referred to McMaster (1967), and Southworth et al. (1992). Flow patterns in Bear Creek from 1985 through 1994 at the USGS gauging station near Highway 95 are illustrated in Fig. 2.1. Average flow from 1991 through October 1994 was 249 L/s. Flow in Bear Creek closely follows precipitation patterns. Average flow for the 1985 through 1991 time period was $200 \mathrm{~L} / \mathrm{s}$. The lowest annual mean occurred in 1988 $(73 \mathrm{~L} / \mathrm{s})$ and the highest annual mean occurred in $1990(312 \mathrm{~L} / \mathrm{s})$.

Precipitation was $89 \%$ of normal in 1988 and $109 \%$ of normal in 1990.

Precipitation is probably the most important climatic factor in hydraulic studies since it establishes the quantity and variation in runoff and streamflow. It also replenishes groundwater (Borders et al. 1993). Precipitation is measured by the National Oceanic and Atmospheric Administration (NOAA) at the Atmospheric Turbulence and Diffusion Laboratory (ATDL) in Oak Ridge. Records are available since 1973 for this site and since May 1947 for previous locations in Oak Ridge. Precipitation is also measured at the burial grounds along Bear Creek. A review of the 1992 precipitation data at the Bear Creek site compared with the data collected at the ATDL site showed that the Bear Creek site received $3.79 \mathrm{~cm}$ more precipitation over the calendar year. The maximum difference occurred in July when the Bear Creek site received about $1.7 \mathrm{~cm}$ more 




Year

Fig. 21. Daily discharge in Bear Creek at USGS gaging station (035382672) 1985 through 1994. Data from 1991 through 1994 are provisional.

precipitation than did the ATDL site. Because there is, on average, little difference between precipitation values for the two sites, and because electronic data files for the ATDL site were readily available, data for the ATDL site were used in the following discussion. Mean monthly precipitation values at the ATDL site from 1990 through 1994 are compared with historical normal precipitation values in Fig. 2.2. In general, precipitation was $109 \%, 111 \%, 81 \%$, and $91 \%$ of normal in 1990, 1991, 1992, and 1993 respectively. Precipitation in the first quarter of 1994 was well above normal (approximately $150 \%$ ). Storms of long duration typically occur during the late fall and winter months, while maximum storms of short duration and high intensity, commonly associated with convective thunderstorm events, occur during spring and summer months (Borders et al. 1993). Four major storms ( $>5 \mathrm{~cm}$ in $24 \mathrm{~h}$ or less) were recorded in 1990, six were recorded in 1991 , zero occurred in 1992, and only one major storm was recorded in 1993. Several major storms of long duration occurred in early 1994. In the 72-h period of February 8 through February $10,11.3 \mathrm{~cm}$ of precipitation was recorded. Similarly, $11.5 \mathrm{~cm}$ of rain fell March 26 through March 28, with $9.43 \mathrm{~cm}$ falling on the 24-h 
ORNL-DWG 96-3534

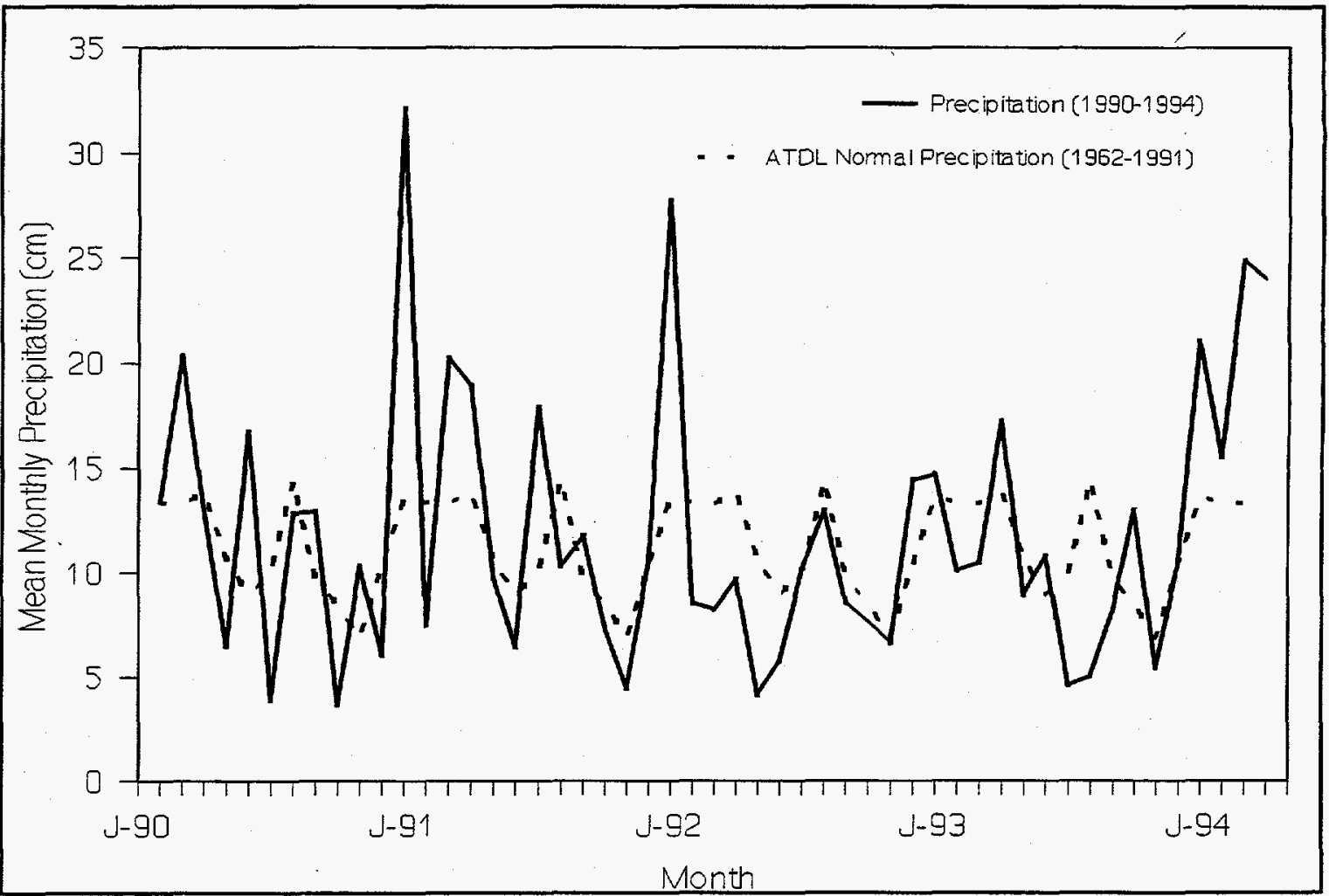

Fig. 2.2. Precipitation measured at the Atmospheric Turbulence and Diffusion Laboratory (ATDL) in Oak Ridge, Tennessee, 1990-94. J = January.

period of March 27. From April 10 through April 12, $13.0 \mathrm{~cm}$ of rainfall was measured at the ATDL, with $6.9 \mathrm{~cm}$ falling on April 12.

\subsection{LAND USE}

Prior to 1940 , agriculture was the dominant land use in the watershed. Aerial photographs show only a narrow strip of riparian vegetation along most of Bear Creek. These agricultural lands are currently planted in pines, and the riparian vegetation today consists primarily of hardwood and mixed hardwood/conifer habitats. For a more detailed synopsis of the habitat types of the Bear Creek Valley, see Turner et al. (1991). Approximately $65 \%$ of the watershed is forest, with old fields, roads, utility corridors, and waste disposal areas comprising the open land areas. The waste disposal areas comprising Operable Unit (OU) 1, located in upper Bear Creek Valley, include the S-3 Ponds, Sanitary Landfill I, Boneyard/Burnyard, the Oil Landfarm, and the Bear Creek Burial Grounds. These units were used until the 1980 s as the primary area for the disposal of various types of hazardous and nonhazardous wastes generated at the Y-12 Plant (Kornegay et al. 1993).

Modifications have been made to the main channel of Bear Creek. Construction of a sanitary landfill, which was in use from 1968 to 1980 , between NT-5 and BCK 11.83 resulted in the relocation of the stream channel south of its original location. Improvements to Bear Creek Road and construction of a utility corridor 
adjacent to Bear Creek Road required relocating the channel north of the original channel between SS-4 and BCK 10.36. The Bear Creek channel was also modified by the following activities: (1) the construction of the National Pollutant Discharge Elimination System (NPDES) monitoring station and weir at BCK 4.55 in 1970 , (2) the excavation of two lagoons near BCK 12.46 in 1972 , (3) the improvements to the overpass and ramps of State Routes 58 and 95 in 1978, and (4) the installation of new culverts near BCK 9.42 in 1986. Additionally, in 1988, the channel near BCK 6.89 was temporarily diverted for installation of culverts during construction of a haul road from the West Borrow area to the burial grounds, and the lagoons located near BCK 12.46 were cleaned and filled with riprap. For additional information concerning these engineering modifications see Turner et al. (1991) or SAIC (1993).

A chronological summary of major events that occurred in the waste disposal areas located in the Bear Creek valley that may have affected water quality in Bear Creek and its tributaries is presented in Table 2.2. This list includes opening/ closing of disposal areas, remedial actions, and disposal activities. A brief description of the waste disposal areas that have influenced water qualiiy in Bear Creek follows; a more exhaustive summary of activities in these areas can be found in the citations listed in Table 2.2 of this report. This discussion contains large excerpts from SAIC (1993, 1994).

S-3 Ponds. The S-3 Ponds were located adjacent to the west end of the Y-12 Plant. The four unlined ponds were constructed in 1951, each had a storage capacity of about 9.46 million liters. The ponds contained variable amounts of sludge ranging from 0.6 to $1.5 \mathrm{~m}$ thick. Waste discharged to the S-3 Ponds was generally classified as toxic, corrosive, or radioactive. The sludges were produced by the neutralization and in situ denitrification of wastewater in the ponds. All waste discharges to the ponds ceased in March 1983; the ponds were closed in 1988.

Rust Spoil Area. The Rust Spoil Area was operated from 1975 to 1983 as a dump, with periodic grading to promote positive drainage. As dumping occurred, the natural topography was elevated and a portion of the Bear Creek channel was filled. Eventually the stream channel course was relocated to the north to compensate for the outslope progression.

Spoil Area 1. Solid waste generated during maintenance and construction activities at the Y-12 Plant has been disposed of in Spoil Area 1 since about 1980. The waste was determined to be nonradioactively contaminated, although construction material disposed in this area may have contained minor amounts of asbestos, mercury, beryllium, uranium, thorium, and other contaminants. Disposal activities were terminated in 1987.

Boneyard/Burnyard. The Boneyard/ Burnyard consists of three sites: the Boneyard, the Hazardous Chemical Disposal Area (HCDA), and the Burnyard. The Boneyard was an active waste-disposal site from 1943 to 1970 . The wastes have been characterized as ranging from ignitable and possibly radioactive to inert. They are known to have included organics, metals, debris, acids, and beryllium. Magnesium chips were burned in pans in the unlined earthen trenches in the southwest corner of the Boneyard. The remaining land in the Boneyard was used to dispose of construction spoil material such as concrete and rebar.

The Burnyard functioned as an active site from 1943 to 1968 . The site received sanitary refuse from plant operations including solids, liquids, and sludges. The waste may have contained empty pesticide containers, metal shavings, solvent oils, and laboratory chemicals. The wastes were placed in unlined trenches and burned. 
Table 2.2. Chronological summary of major events in the Bear Creek Valley Operable Units that may have affected water quality in Bear Creek and its tributaries

Year Event

1943 The Boneyard was used as a disposal and burning site for sanitary, metallic, chemical, and radioactive wastes. The Burnyard received sanitary refuse from plant operations including solids, liquids and sludges.

1951 The S-3 Ponds were constructed., consisting of four lined surface impoundments with a total storage capacity of 38 million $\mathrm{L}$. Waste disposal included nitrate solutions, nitric acid, pickling and plating wastes, miscellaneous wastes associated with routine cleanup operations, dilute acids, machine coolants, depleted uranium, technetium, caustic solutions, bionitrification sludges, and acids with $\mathrm{pH}<2.0$.

1955 Disposal at the Burial Grounds began with the disposal of solid waste in Unit A. The Burial Grounds consisted of waste disposal units A, B, C, D, E, and J. Each unit consisted of a series of trenches 4.3 to $7.6 \mathrm{~m}$ deep, that were used for the disposal of liquid and solid wastes.

1959 Large volumes of solvent-contaminated water and oils began being disposed of in BG-A.

1959 From 1959 to 1986 the SY-200 area was used as a temporary storage area for equipment, machinery, and miscellaneous items including electrical transformers, piping, tanks, and mercury flasks. All stored items were removed in 1986.

1961 Surface tank installed in BG-A to hold waste oils and coolants; accumulation were burned. Unburned liquids were drained into trenches.

1962 BG-B opened and used for disposal of depleted uranium metal and oxides.

1962 BG-C opened for the disposal of beryllium, beryllium oxide, thorium, and solid waste contaminated with these materials. Other contaminated materials with enriched uranium were also disposed of.

1966 Walk-In Pits established in the Burial Grounds to dispose of chemicals and uranium metal saw fines.

1968 Burning of waste oils and coolants terminated in BG-A.

1968 BG-D opened to replace BG-B.

1968 Disposal of wastes at the Burnyard was discontinued.

1969 Oil first observed seeping from the ends of trenches in BG-A to NT-7 and from the soil surface above the oil disposal pits. 1969-71.

1970 Disposal of wastes at the Boneyard was discontinued.

1971 ORP 1 was constructed.

1972 ORP 2 was constructed on NT-6 at the NE corner of BG-A.

1973 Activities began at the oil landfarm site. Waste oils and coolants that contained beryllium compounds, depleted uranium, PCBs and chlorinated organic compounds, mop waters, tanker oils from the K-25 site, wastes from cooling towers and the Burial Grounds, and cridentified miscellaneous liquid wastes were disposed of at the site. 
Table 2.2 (continued)

Year

Event

1974 Approximately 57,000 L of oil skimmed from the surfaces of the ORPs for disposal at the Oil Landfarm. 1974-75

1975 A Hazardous Chemical Disposal Area was established on $\sim 2$ acres in the southeastern portion of the Boneyard/Burnyard on top of the Burnyard. The area was used to burn neutralized liquid and gaseous wastes. The material was broadly characterized as ignitable, reactive, corrosive, toxic, highly flammable, or, in some instances, inert.

1975 Since 1975, no significant accumulation of oil has occurred on the surface of ORP 2.

1975 Disposal operations on the 5.4 acre rust spoil area (RSA) site began. Disposal material included solid waste (spoil material) generated from renovation, maintenance, and construction operations at the Y-12 Plant. The bulk of the material included soil, masonry material, and metal. In addition, possible quantities of asbestos, mercury, uranium, and solyents may have been disposed at the site. Disposal operations included periodic grading and progressed from Old Bear Creek Road to the north. As dumping occurred, the natural topography was elevated and a portion of the Bear Creek channel was filled. Eventually, the stream channel course was relocated to the north to compensate for the out slope progression.

1976 The nitric acid recovery system became operational (S-3 Ponds).

$197968,400 \mathrm{~L}$ of oil removed from ORP 1.

1979 Oil disposal ceased at the Burial Grounds.

1979 Oils were analyzed for uranium, beryllium, thorium and PCBs before being disposed of at the Oil Landfarm. Permissible concentration levels of $5 \mathrm{mg} / \mathrm{L}$ was established for PCBs. Waste with $>5 \mathrm{mg} / \mathrm{L}$ uranium were stored for incineration at K-25 Plant.

1980 Disposal operations began on the -5 -acre SA-1 site. Disposal material included nonhazardous, nonradioactively contaminated construction debris from various renovation, maintenance, and construction operations at the Y-12 Plant.

1981 Disposal was discontinued at the Hazardous Chemical Disposal Area.

1981 Analyses of wastes at the Oil Landfarm expanded to include chlorinated hydrocarbons with a maximum permissible concentration of $3 \%$.

1981 After 1981, Walk-In Pits is used solely for disposal of uranium metal saw fines.

1982 Oil Landfarm operations ceased.

1983 The underground pipeline used to transport waste to the S-3 Ponds was plugged and abandoned. All waste discharges were terminated in March. In situ treatment of wastewater in the ponds began. Liquid in all four ponds was neutralized, May-November. Biodenitrification of liquids occurred. Nitrate levels in the pond water decreased to $\sim 100 \mathrm{ppm}$.

1983 Water and sediment samples collected from NT-6 and 7 showed elevated levels of several VOCs in both water and sediments downstream of NT-7. Sediment from ORP 1 and NT-7 downstream of the pond did not show elevated levels of toxic materials, cyanide or phenols compared with control site on NT-7 upstream from Burial Grounds. Samples from ORP 1 contained PCBs ranging from 3 to $31 \mathrm{mg} / \mathrm{L}$. 
Table 2.2 (continued)

Year Event

1983 RSA site closure activities were initiated. About $7250 \mathrm{yd}^{3}$ of spoil from long the outer slope were excavated and placed on top of the spoil pile. The area was graded and shaped, then the entire area was covered with a minimum of $2 \mathrm{ft}$ of soil. Vegetative growth was established over the disturbed area.

1984 In situ treatmerii of wastewater in the S-3 Ponds completed. Nitrate levels maintained $<50$ ppm.

1984 RSA closure activities were completed in mid-1984.

1985 An investigation conducted by Bechtel National, Inc. on sediment samples collected downstream of the Boneyard indicated the presence of mercury, uranium, several polynuclear aromatic hydrocarbons, and phthalates.

1985 Supernatant treatment to remove trace metals and organics began at the S-3 Ponds. The treated effluent was discharged to EFPC in accordance with the NPDES permit.

1985 The RSA began current use as an equipment/supply aboveground storage yard.

1985 SA-1 closure activities began by placing a clay soil cover (minimum of $2 \mathrm{ft}$ ) over the site after final deposition of the waste and establishing a grass ground cover.

1986 All stored items were removed from the SY-200 yard.

1988 S-3 Ponds were closed with a multi-layered RCRA cap. Currently the site is covered with asphalt and used as a parking lot.

1988 Construction of the ESF began.

1988 The ESF foundation was excavated. First, $0.5 \mathrm{ft}$ gravel and soil was removed, then an additional $8 \mathrm{ft}$ was removed. Soil was bermed in the southwest and northeast corners of the SY-200 yard respectively. Construction activities ceased because no natural solid were encountered during the excavation process.

1989 The Hazardous Chemical Disposal Area was covered with a RCRA-type cap.

1989 Both ORP 1 and 2 were cleaned out and an engineered cap was constructed over each pond.

1989 BG-A and BG-C west were closed in place as a landfill and covered with an engineered cap.

1989 Construction at the ESF was resumed. The excavated soils were spread back onto the site.

1989 The RFI work plan for the SY-200 yard prepared by Geraghty and Miller listed COPCs as PCBs, mercury, and lead.

1989 The RFI work plan for the RSA prepared by Battelle Corporation listed COPCs as asbestos, mercury, uranium, and solvent-contaminated material.

1990 The Oil Landfarm was closed as a landfill with a multilayered engineered cap.

1990 TDEC granted approval for final closure of BG-A. 
Table 2.2 (continued)

Year

Event

1990 Construction at the ESF was postponed due to the presence of mercury and asbestos in some of the excavated soils.

1991 Results of soil and groundwater studies in the SA-1 area confirmed the presence of heavy metals and radiological contamination.

1993 The RI work plan for the ESF listed the COPCs as barium, chromium, lead, mercury, PCBs, and uranium.

1993 The RI work plan for RSA lists the COPCs as arsenic, beryllium, lead, mercury, selenium, thorium, uranium, and tetrachloroethene.

1993 The RI work plan listed the COPCs at the SA-1 site as arsenic, beryllium, barium, chromium, lead, mercury, fluoranthene, phenanthrene, pyrene, radium, and uranium.

Note: This table was compiled from tables and text in the following references and citations found therein. SAIC. 1994. Remedial Investigation Report on the Bear Creek Valley Operable Unit 2 (Rust Spoil Area, Spoil Area 1, and SY-200 Yard) at the Oak Ridge Y-12 Plant, Oak Ridge, Tennessee. Vol. 1. Main Text. DOE/OR/011273/V1\&D1.; SAIC. 1993. Remedial Investigation Work Plan for Bear Creek Valley Operable Unit 4 (Shallow Groundwater in Bear Creek Valley) at the Oak Ridge Y-12 Plant, Oak Ridge, Tennessee. DOE/OR/01-1115\&D3.; SAIC. 1993. Remedial Investigation Work Plan for Bear Creek Valley Operable Unit 1 (S-3 Ponds, Boneyard/Burnyard, Oil Landfarm, Sanitary Landfill I, and the Burial Grounds, Including Oil Retention Ponds 1 and 2) at the Oak Ridge Y-12 Plant, Oak Ridge, Tennessee. Vol.1. Main Text. DOE/OR/01-1161N1\&D1.

$\mathrm{BG}=$ burial ground, SY $=$ Spoil Yard, NT = north tributary, ORP = Oil Retention Pond, PCBs = polychlorinated byphenyls, RSA = Rust Spoil Area, VOCs = volatile organic compounds, ESF = Environmental Support Facility, RCRA = Resource Conservation and Recovery Act, RFI = RCRA Facility Investigation, TDEC $=$ Tennessee Department of Environment and Conservation, COPC $=$ contaminant of potential concern.

The HCDA is part of the Boneyard/ Burnyard area; it is located directly southwest of the Boneyard, on top of the Burnyard. The site received solid, liquid and gaseous wastes from 1975 to 1981 . The material was broadly characterized as ignitable, reactive, corrosive, toxic, highly flammable, or in some instances inert.

Sanitary Landfill 1. The Sanitary Landfill (SL) 1 received combustible and decomposable solids wastes from 1968 to 1980. The landfill was permitted for material such as paper and cardboard, plastics, rubber, wood, brush, animal bedding, organic garbage, textile products, and asphalt roofing materials.

Administrative controls were used to exclude the disposal of toxic chemicals and other contaminated materials; however, it is possible that some of these materials were disposed of in the SL (Energy Systems 1987).

Burial Grounds. Several principal waste-disposal units designated BG-A, $-B$, $-\mathrm{C},-\mathrm{D},-\mathrm{E}$, and $-\mathrm{J}$, the walk-in Pits, and the Uranium Vaults are collectively referred to as the Burial Grounds. Each wastedisposal unit consists of a series of trenches used for disposal of liquid or solid wastes. Waste materials disposed of in the Burial Grounds included heavy metals, oils and coolants, salts, debris, solvents, ethylene diamine tetra-acetic acid (EDTA), asbestos, mop water, and radioisotope contaminated materials. Capping of the Burial Grounds began in 1989.

Oil Retention Ponds. The Oil Retention Ponds (ORPs) were constructed 
to prevent downstream transport of oil in NT 6 and 7. Oil was first observed seeping from BG-A to NT 7 between 1969 and 1971 at which time oil disposal to BG-A was discontinued. To prevent oil from being transported down NT 7 to Bear Creek, ORP 1 was constructed in 1971. Oil seepage was observed above NT 6 before 1972. ORP 2 was constructed in 1972 to prevent transport of oil via NT 6. Both ponds were closed and capped in 1989.

\subsection{WATER QUALITY}

The effects of facility effluents to the natural receiving waters are assessed though the ORR surface water monitoring program. The bodies of regulations promulgated by the EPA to control impacts to surface water quality by toxic and hazardous chemicals are collectively known as the Clean Water Act (CWA) regulations. These regulations include the NPDES requirements. The bases for the NPDES permit requirements are the stream classifications and general water quality criteria authorized by the CWA and established by the state of Tennessee (Kornegay et al. 1993). The intent of NPDES permits is to establish effluent contamination limits that protect the classified uses of the surface waters. The classified uses of Bear Creek include the propagation of fish anci aquatic life, recreation, irrigation, livestock watering, and wildlife.

Surface water in the Bear Creek watershed is affected by surface and subsurface drainage from waste burial grounds, the Oil Landfarm, seepages from the S-3 Pond area, construction-related disturbances, and several large springs. An extensive review of water quality in Bear Creek can be found in Turner et al. (1991), Southworth et al. (1992), and SAIC (1993). As a general summary, water quality in Bear Creek was characterized by
(1) high concentrations of dissolved salts resulting from the infiltration of contaminated groundwater in the vicinity of the S-3 Ponds; (2) elevated

concentrations of some trace ions in the upper reaches of Bear Creek (that declined to about background levels or to below detection limits within a short distance downstream); (3) elevated levels of metals in the sediments in the upper stream reaches; (4) elevated levels of volatile organic compounds entering Bear Creek though NT 7 and 8; and (5) the presence of PCBs in the sediments and biota.

Surface water monitoring is currently conducted at BCK 12.4 and 11.97 in response to a memorandum of understanding agreed to by the U.S. Department of Energy (DOE), EPA and the Tennessee Department of Environment and Conservation (TDEC) (Kornegay et al. 1993). The monitoring site at BCK 12.4 was agreed upon as a site that was characteristic of the effects of the seepage of the S-3 Ponds. Because of decreased flow at the site since the closure of the S-3 Ponds, a new site at BCK 11.97 is also being monitored and has been proposed as a replacement site (Kornegay et al. 1993). In addition to the conventional water quality parameters monitored at these site, radiological monitoring is also conducted at both locations. All radiological results were well below the derived concentration values (DCGs) listed in DOE Order 5400.5 for both sites, with ${ }^{237} \mathrm{~Np}$ being the only radionuclide exceeding $2 \%$ of a DCG (3.77\% and $2.35 \%$ at BCK 11.97 and 12.4 respectively) (Kornegay et al. 1993). Bear Creek kilometer 4.55 , also designated as NPDES outfall 304, is also monitored for radiological parameters. All radiological results were well below DCGs at this location.

Mean concentrations of total uranium have decreased from $0.58 \mathrm{mg} / \mathrm{L}$ (at $\mathrm{BCK} 11.81$ ) in 1986 to $0.13 \mathrm{mg} / \mathrm{L}$ (at 
BCK 11.97) in 1994. Concentrations of uranium at $\mathrm{BCK} 12.36$ were $0.51 \mathrm{mg} / \mathrm{L}$ in 1986. Mean levels at BCK 12.4 did not drop below $0.5 \mathrm{mg} / \mathrm{L}$ until 1994 (Tables A.1-A.5).

The results of nonradiological monitoring from 1990 through 1994 for BCK 11.97 and 12.4 are presented in Tables A.1-A.5. During this time $\mathrm{Cd}, \mathrm{Cr}$, $\mathrm{Cu}, \mathrm{Pb}, \mathrm{Hg}, \mathrm{Se}, \mathrm{Ag}$, and PCBs have exceeded the Tennessee Water Quality Standards for these parameters; however, in many cases the analytical detection limit of the parameter was higher than the reference value (see Tables A.1-A.5).

Conservative water quality parameters measured as part of the toxicity monitoring task (see Section 3.3.2) showed that mean levels of hardness and conductivity were high compared with those reported for other chemically perturbed streams on ORR. Levels of hardness, conductivity, and alkalinity in Bear Creek declined consistently (up to about 2.7 fold for conductivity) from BCK 12.36 to BCK 7.87. Previous studies (Southworth et al. 1992) have shown that Bear Creek has high concentrations of dissolved salts, especially calcium. Calcium levels are still approximately four times higher than calcium levels measured in Grassy Creek (Table 2.3 in Southworth et al. 1992). Sodium levels are consistently elevated compared with values previously measured in Grassy Creek. Recent studies (see Section 3.4) have hypothesized that the constituents that contribute to conductivity and hardness conditions in upper Bear Creek may be a factor in the increased mortality of Ceriodaphnia when exposed to upper Bear Creek water.

Prior to the discontinuation of use and neutralization of the S-3 Ponds at the headwaters of Bear Creek in 1983, the upper reaches of the stream were acidic and highly enriched with many inorganic constituents (Southworth et al. 1992 and references contained therein). In the $1970 \mathrm{~s}, \mathrm{pH}$ values ranged from 3.5 to 6.8 over a 5-month period (ERDA 1975). Within several months of neutralization of the S-3 Ponds, $\mathrm{pH}$ levels rose to more than 7.0 (Southworth et al. 1992). From 1990 through 1994, $\mathrm{pH}$ values have ranged from 6.7 to 8.8 , which is within the Tennessee Water Quality Standard reference values for this parameter.

Aluminum concentrations declined after neutralization of the S-3 Ponds, but are still elevated compared with those measured previously at Grassy Creek, the reference stream. Other constituents that are still elevated compared with the reference stream include barium, boron, nitrate (as N), potassium, and sodium.

Even though many water quality parameters are measured at higher concentrations in Bear Creek than in the reference stream, the general trend has been an overall reduction in concentrations since the S-3 Ponds were closed. At BCK 12.4 and 11.97, concentrations of nitrides have been reduced from $7150 \mathrm{mg} / \mathrm{L}$ in 1986 to $<50 \mathrm{mg} / \mathrm{L}$ in 1994 ; calcium levels have dropped from $7300 \mathrm{mg} / \mathrm{L}$ to $<150 \mathrm{mg} / \mathrm{L}$; and conductivity has declined from $2000-4000 \mu \mathrm{S} / \mathrm{cm}$ to $<1400 \mu \mathrm{S} / \mathrm{cm}$. These reductions may help explain the recolonization of this reach of stream by fish and macroinvertebrates.

\subsection{AMBIENT TEMPERATURE REGIMES}

Continuous monitoring of instream water temperature has been ongoing at three Bear Creek sites (BCK 7.87, 9.40, and 9.91) since 1985 (Southworth et al. 1992). A fourth site, BCK 11.98, has been monitored since April 1987, as has a reference site on Grassy Creek at GCK 2.4. Monitoring at this reference site was discontinued in December 1992 due to increasing siltation (M. G. Ryon, pers. comm., May 26, 1994) and difficulty in accessing the site. A new reference site was established in nearby Gum Hollow 
Creek at kilometer (GHK) 2.9 in August 1993. Hourly temperature data were collected at each of these sites using Ryan Tempmentor digital thermographs (tempmonitors), Ryan Instruments, Redmond, Washington. Mean monthly temperature data for the years 1988 through 1993 are summarized in Figs. 2.3 and 2.4, and Appendix A (Table A.6).

Temperatures as high as $38^{\circ} \mathrm{C}$ were recorded at the uppermost site, BCK 11.98, during the first year (1987) of monitoring (Southworth et al. 1992). In the 6 following years, temperatures in excess of $30^{\circ} \mathrm{C}$ have only been recorded during 4 months (Table A.2), and even these are well below the $38^{\circ} \mathrm{C}$ temperatures observed in August 1987. This site is characterized by a narrow channel with steep cut banks, low flow, and little or no overhanging vegetation. Site BCK 11.98 is not significantly influenced by springs (Southworth et al. 1992) and has experienced intermittent flow during hot, dry periods (personal observation). With one notable exception, no other Bear Creek or reference stream site had temperatures in excess of $30^{\circ} \mathrm{C}$ during the period of record (January 1988-December 1993).

In December of 1992, extremely high temperatures were recorded twice at BCK 9.91. The first occurrence was a $70.3^{\circ} \mathrm{C}$ reading at approximately $6: 30$ p.m. on December 26. The second occurrence was a $78.0^{\circ} \mathrm{C}$ reading (Table A.6) at approximately 7:30 p.m. on December 29. Though aberrant readings may occur with any automated recording device, these isolated readings are not easily discounted. In each instance, the reading 1 hour after the high-temperature spike was approximately $2.5^{\circ} \mathrm{C}$ higher than the prespike temperatures. Temperatures remained at least $2^{\circ} \mathrm{C}$ higher than prespike levels for 18 hours in the first case and about 2.5 days in the second case.

There are no substantial outfalls or springs in the vicinity of BCK 9.91. North tributary 7 , a small drainage, flows into Bear Creek from the north $65 \mathrm{~m}$ upstream of this site (directly above the road crossing). South spring 4 enters Bear Creek from the south a little more than $200 \mathrm{~m}$ upstream of the site. It is not likely, nor perhaps even possible, that either of these tributaries could influence the BCK 9.91 tempmonitor enough to cause such high readings. Discharge of a copious amount of a high temperature substance at, or upstream of, the tempmonitor could explain these elevated temperature readings. Nevertheless, the validity of these data will probably never be ascertained. If the two highest readings are deleted from the data, the monthly mean temperature $\left({ }^{\circ} \mathrm{C}\right) \pm 1 \mathrm{SD}$ for December 1992 is $7.4 \pm 1.5$ and the range is 4.2-11.7. (For comparison, see Appendix A, Table A.6.)

Routine temperature monitoring at BCK 9.40 was discontinued on May 1 , 1991. One of the primary reasons for monitoring this site was to determine the potential effects of SS-5, located immediately upstream, on Bear Creek temperatures. This site consistently has higher winter and lower summer temperatures than sites both upstream and downstream of it. Since 1988, mean monthly temperatures have been as much as $3.5^{\circ} \mathrm{C}$ warmer in winter and $6^{\circ} \mathrm{C}$ cooler in summer than other Bear Creek sites (Fig. 2.3). This relatively localized, moderating effect of SS-5 on Bear Creek temperatures is consistent with the findings of Southworth et al. (1992). Temperatures more than $1.5 \mathrm{~km}$ downstream, at BCK 7.87, are similar year-round to those found at BCK 9.91. Further monitoring at BCK 9.40, without some alteration to the system, is unlikely to yield new information. 
ORNL-DWG 96-3535
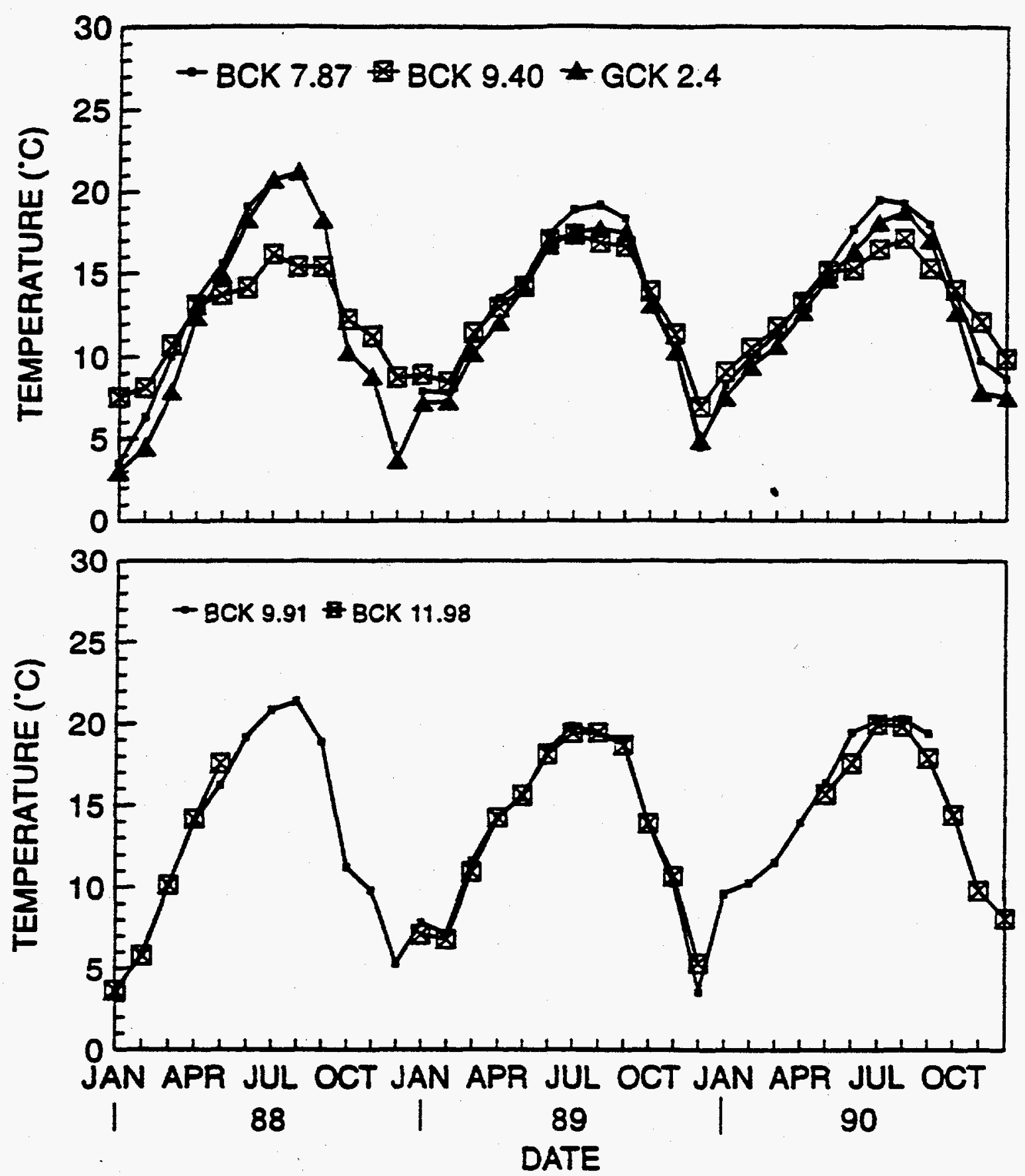

Fig. 23. Mean monthly temperatures at Bear Creek kilometers 7.87, 9.40, 9.91, and 11.98, and at Grassy Creek kilometer 24, 1988-90. Data collected hourly using Ryan Tempmentor digital thermographs. Temperature record is incomplete due to equipment failure. 

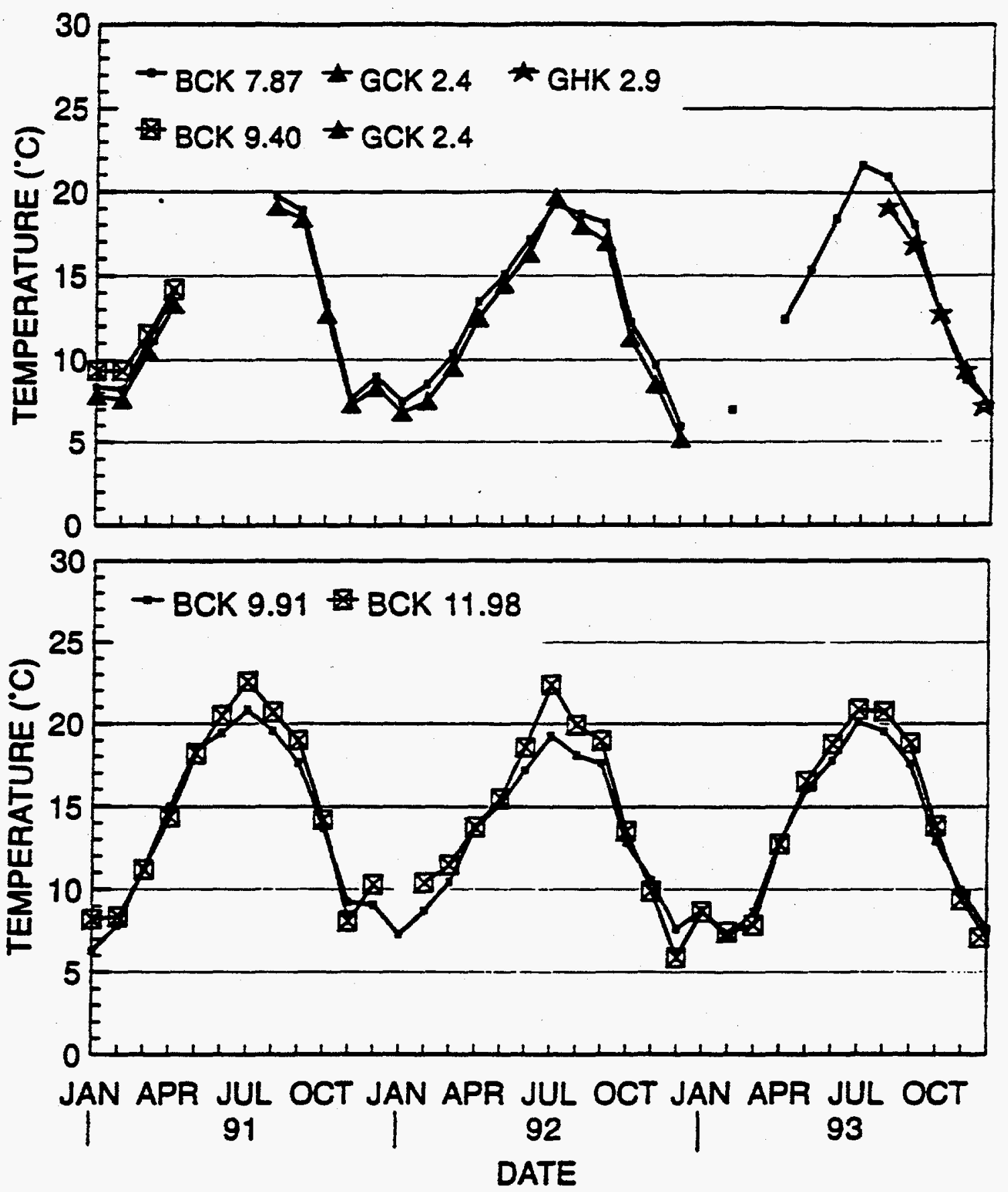

Fig. 2.4. Mean monthly temperatures at Bear Creek kilometers 7.87, 9.40, 9.91, and 11.98, and at Grassy Creek kilometer 24, and at Gum Hollow Creek kilometer 1.9, 1991-93. Data collected hourly using Ryan Tempmentor digital thermographs. Temperature record is incomplete due to equipment failure and lack of tempmentor deployment. 


\section{TOXICITY MONTTORING}

A. J. Stewart, L. F. Wicker, and T. L. Phipps

\subsection{INTRODUCTION}

Ambient toxicity tests permit direct assessment of the biological quality of the water in rivers, ponds, lakes or streams. In 7-d static-renewal ambient tests, the water samples that are being tested are collected daily (usually as grab samples), and the test solution to which the organisms are exposed is changed daily. Responses of the organisms to the ambient water (e.g., growth, survival, or reproduction) can then be compared with the responses of organisms tested in reference water to determine whether the ambient water is toxic. By design, ambient toxicity tests deliberately include variations attributable to time (e.g., day-to-day variations, for 7-d test periods; or test-to-test variations in water quality due to season and weather conditions). By selecting multiple sampling sites within a stream, ambient toxicity tests also can deliberately incorporate a component of spatial variation. If conducted repeatedly through time, ambient toxicity tests of water from multiple sites can be used to document changes in water qualiiy that might result from remedial actions or changes in facility operations and may reveal general longitudinal patterns in the biological quality of the water. Longitudinal patterns in biological quality of the water in a stream could be caused by point- or areasource inputs of toxic pollutants, dilution with distance downstream, or chemical alteration of toxic pollutants (e.g., photolysis, hydrolysis, volatilization, sorptive losses to the sediments, or biodegradation). Static-renewal ambient toxicity tests involve application of EPAapproved testing methods, have short turnaround times, and directly assess the potential for biological effects due to the presence of water-borne pollutants. For these reasons, ambient toxicity tests often are used to support ecological risk assessments and meet Clean Water Act objectives. This section presents the results of ambient toxicity tests used to assess water-quality conditions in Bear Creek.

\subsection{METHODS AND MATERIALS}

\subsubsection{Toxicity Test Procedures}

Ambient toxicity of water from various sites in Bear Creek was evaluated using 7-d static-renewal chronic toxicity tests based on the survival and growth of fathead minnow (Pimephales promelas) larvae, and the survival and reproduction of a daphnid (Ceriodaphnia dubia). The procedures for these tests are described in Weber et al. (1989); examples of the use of these test procedures for ambient assessments can be found in Burton et al. (1987), Stewart et al. (1990), Nimmo et al. (1990), NorbergKing et al. (1991), Kszos and Taylor (1992a), Stewart and Loar (1990), and Stewart, unpublished data. Toxicity tests with fathead minnow larvae and Ceriodaphnia were conducted concurrently in almost every case. During each test period, a diluted mineral water solution that lacked toxicants at toxic concentrations was included as a negative control. In most of the test periods, dilutions of water from BCK 12.36 (e.g., $100 \%, 80 \%, 60 \%$ of full-strength, etc.) were tested also, to provide an estimate of the ambient water's no-observed effect 
concentration (NOEC). These dilutions were prepared by mixing water from BCK 12.36 with the appropriate amount of diluted mineral water.

\subsubsection{Chemical Analyses}

On each day of the testing periods, subsamples of the water samples that were being tested for toxicity were also analyzed for $\mathrm{pH}$, conductivity, alkalinity, and hardness. Measurements of these parameters are made using standard EPA procedures (Kszos et al. 1989). The temperature of the water at each site was recorded when the sample was collected. Data from the toxicity and chemical tests of the ambient and effluent samples were recorded in Oak Ridge National Laboratory (ORNL) registered laboratory notebooks.

\subsubsection{Toxicity Testing Locations and Schedules}

In this report, we summarize the results of ambient toxicity tests of mainstem sites in Bear Creek that were conducted between March 1, 1990, and August 10, 1994: the results of tests conducted before March, 1990 were reported by Southworth et al. (1992). Additionally, Ceriodaphnia and fathead minnow toxicity tests were used to assess water quality of tributary sites in Bear Creek, as part of the Remedial Investigation for Bear Creek Valley Operable Unit 4. In these tests, water samples collected from eight north tributaries, five south springs, and seven BMAP sampling sites within the main channel of Bear Creek were tested with fathead minnow larvae and Ceriodaphnia during May 19-26 and August 4-10, 1994.
Water from a reference site in Hinds Creek was assessed during both of these test periods.

Collectively, 54 site-date combinations were tested with Ceriodaphnia and/or fathead minnow larvae (Table 3.1). In 48 of the 54 cases, water samples for the sitedate combinations were tested simultaneously with both species. Ceriodaphnia (but not fathead minnow larvae) were used to test water from four sites in Bear Creek during September 1992 and on two dates in 1990 at BCK 12.36 (Table 3.1 and Fig. 3.1). During periods when water samples were being tested with both species concurrently, the following sites were assessed: BCK 12.36, 11.83, 11.09, 9.91, 9.40, and 7.87 (Table 3.1).

\subsubsection{Statistical Procedures}

All statistical computations were made using procedures in the Statistical Analysis System (SAS 1985a, 1985b) on personal computers. Survival values for the minnows were transformed (arc sine square root; Steel and Torrie 1960) before analysis. The general approach used for analysis of the toxicity test results was that of two-way analysis of variance (ANOVA; SAS General Linear Model). Site, date, and the interaction term between site and date, were included as independent (i.e., explanatory) variables; Ceriodaphnia survival and reproduction, and fathead minnow survival and growth, were used as dependent (i.e., response) variables. Thus, the ANOVAs considered both spatial and temporal variation in toxicity test results. Duncan's Multiple Range Test was used to determine which sites or dates accounted for significant differences that were detected by ANOVA, and to summarize means, by test and by site, of the toxicity test results. 
Table 3.1. Toxicity testing in Bear Creek, March 1, 1990, through August 4, 1994

\begin{tabular}{|c|c|c|c|c|c|c|c|c|c|c|c|}
\hline \multirow[b]{2}{*}{ Site ${ }^{a}$} & \multicolumn{11}{|c|}{ Date when test was initiated } \\
\hline & $\begin{array}{c}\operatorname{Mar} 1 \\
1990\end{array}$ & $\begin{array}{c}\text { Sep } 6 \\
1990\end{array}$ & $\begin{array}{c}\text { Oct } 31 \\
1991\end{array}$ & $\begin{array}{c}\text { Jul } 30 \\
1992\end{array}$ & $\underset{1992}{\text { Sep } 15}$ & $\begin{array}{c}\operatorname{Jan} 14 \\
1993\end{array}$ & $\begin{array}{c}\operatorname{Mar} 11 \\
1993\end{array}$ & $\begin{array}{c}\text { May } 20 \\
1993\end{array}$ & $\underset{1993}{\text { Aug } 5}$ & $\begin{array}{c}\text { May } 19 \\
1994\end{array}$ & $\begin{array}{c}\text { Aug } 4 \\
1994\end{array}$ \\
\hline BCK 12.36 & $\mathrm{C}$ & C & $\mathrm{C}, \mathrm{F}$ & $\mathrm{C}, \mathrm{F}$ & $\mathrm{C}$ & $\mathrm{C}, \mathrm{F}$ & C, F & $\mathrm{C}, \mathrm{F}$ & $\mathrm{C}, \mathrm{F}$ & $\mathrm{C}, \mathrm{F}$ & $\mathrm{C}, \mathrm{F}$ \\
\hline BCK 11.83 & - & - & $\mathrm{C}, \mathrm{F}$ & $\mathrm{C}, \mathrm{F}$ & $\mathrm{C}$ & $\mathrm{C}, \mathrm{F}$ & $\mathrm{C}, \mathrm{F}$ & C, F & $\mathrm{C}, \mathrm{F}$ & $\mathrm{C}, \mathrm{F}$ & $\mathrm{C}, \mathrm{F}$ \\
\hline BCK 11.09 & - & - & $\mathrm{C}, \mathrm{F}$ & $\mathrm{C}, \mathrm{F}$ & $\mathrm{C}$ & $\mathrm{C}, \mathrm{F}$ & $\mathrm{C}, \mathrm{F}$ & $\mathrm{C}, \mathrm{F}$ & $\mathrm{C}, \mathrm{F}$ & $C, F$ & $\mathrm{C}, \mathrm{F}$ \\
\hline BCK 9.91 & - & - & $\mathrm{C}, \mathrm{F}$ & $\mathrm{C}, \mathrm{F}$ & $\mathrm{C}$ & $\mathrm{C}, \mathrm{F}$ & $\mathrm{C}, \mathrm{F}$ & $\mathrm{C}, \mathrm{F}$ & $C, F$ & $\mathrm{C}, \mathrm{F}$ & C. F. \\
\hline BCK 9.40 & - & - & $\mathrm{C}, \mathrm{F}$ & $\mathrm{C}, \mathrm{F}$ & - & $\mathrm{C}, \mathrm{F}$ & C, F & $\mathrm{C}, \mathrm{F}$ & $\mathrm{C}, \mathrm{F}$ & $\mathrm{C}, \mathrm{F}$ & $\mathrm{C}, \mathrm{F}$ \\
\hline BCK 7.87 & - & - & $\mathrm{C}, \mathrm{F}$ & $\mathrm{C}, \mathrm{F}$ & - & $\mathrm{C}, \mathrm{F}$ & C, F & $C, F$ & $\mathrm{C}, \mathrm{F}$ & C, F & $\mathrm{C}, \mathrm{F}$ \\
\hline
\end{tabular}

${ }^{a} \mathrm{BCK}=$ Bear Creek kilometer.

Note: $\mathrm{C}=$ Ceriodaphnia dubia 7-d survival and reproduction test; $\mathrm{F}=$ fathead minnow larvae 7-d survival and growth test; "-." $=$ not tested. 


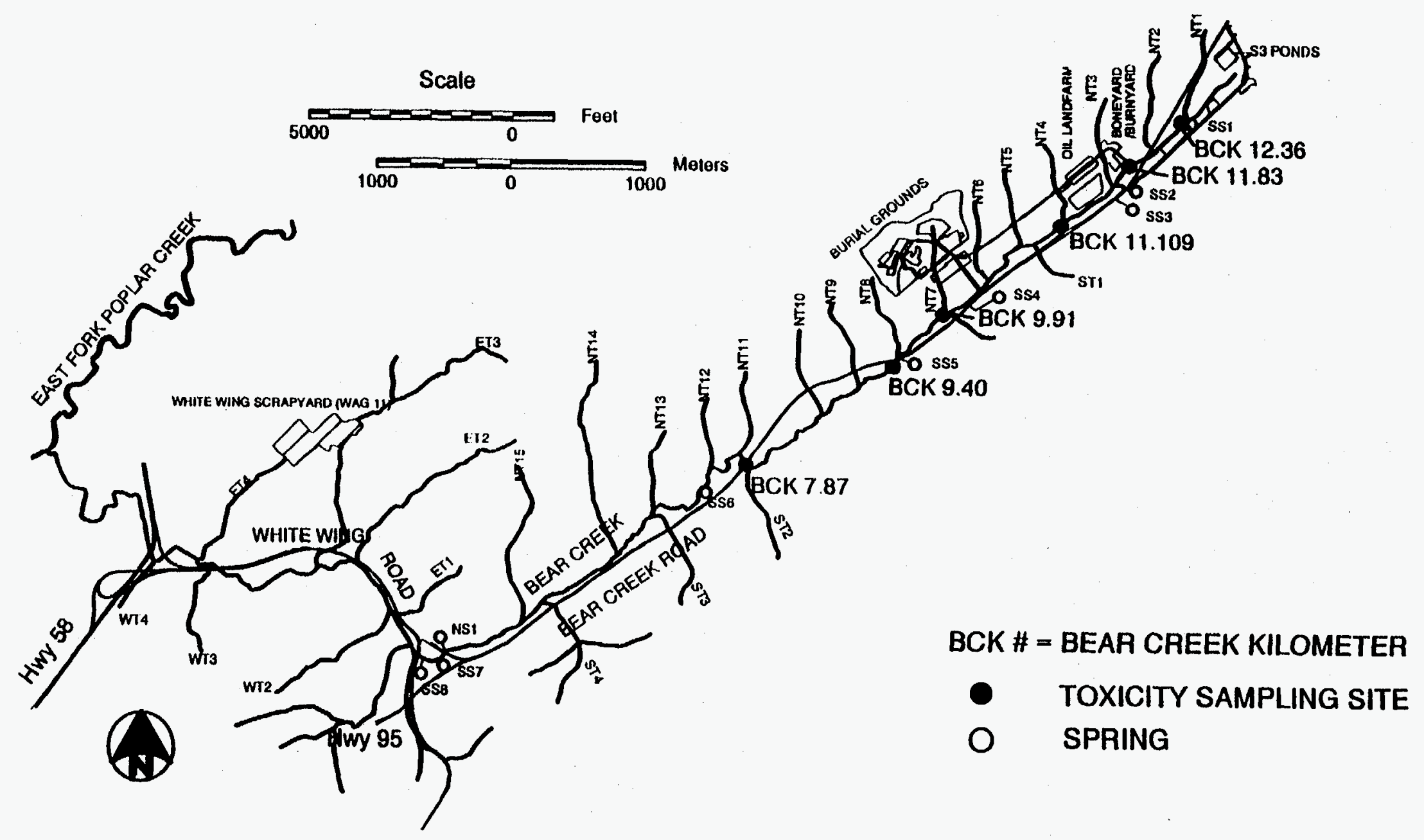

Fig. 3.1. Location of toxicity testing sampling sites. WT $=$ west tributary, ET = east tributary, $\mathrm{ST}=$ south tributary, NT $=$ north tributary, SS = south spring, NS = north spring. 


\subsection{RESULTS}

\subsubsection{Toxicity Test Acceptability}

Based on EPA criteria for test acceptability, the toxicity tests were valid in each test period (Weber et al. 1989): survival of the minnow larvae in controls ranged from $87.5 \%$ to $100 \%$, mean growth of fathead minnow larvae in controls ranged from $0.37 \mathrm{mg} /$ fish to $0.77 \mathrm{mg} /$ fish, survival of Ceriodaphnia in controls was $280 \%$ in every test period, and Ceriodaphnia reproduction in controls was $>18.2$ offspring per female (Table 3.2).

\subsubsection{Ceriodaphnia Toxicity Test Results - Survival}

In 7-d tests of water from reference sites in headwater streams on ORR, survival of Ceriodaphnia is rarely $\leq 60 \%$ (Stewart 1995). This finding permits reliable use of the $60 \%$-survival criterion as a "pass-fail" boundary. Using this criterion, water from BCK 12.36 provided strong evidence for toxicity: in 9 of 11 test periods, Ceriodaphnia survival was $\leq 60 \%$. Thus, this site had a toxicity test failure frequency of $81.8 \%$. Water from BCK 11.83 was toxic less frequently than it was at BCK 12.36: at BCK 11.83, the Ceriodaphnia toxicity test failure frequency (survival criterion) was 50\%. At BCK 9.91, 9.40, and 7.87, Ceriodaphnia toxicity test failure frequency was zero. The distribution of survival values for Ceriodaphnia tests of the six Bear Creek sites is summarized in Table 3.3.

\subsubsection{Ceriodaphnia Toxicity Test Results - Reproduction}

Ceriodaphnia reproduction also provided strong evidence for toxicity in upper Bear Creek. ANOVA showed that site alone explained $54.1 \%$ of the variation in mean reproduction, and Duncan's test showed that mean reproduction was low both at BCK 12.36 and 11.83 (Table 3.4). In tests conducted during March 1990 and May 1994, Ceriodaphnia mean reproduction, pooled for all sites including control, was low ( $<20$ offspring per female). ANOVA showed that site, date, and the site-date interaction term together accounted for $63.5 \%$ of the variation in Ceriodaphnia reproduction. In this analysis, site, date, and the interaction term between site and date were all highly significant $(p<0.0001$ in each case). Previous studies have shown that data-set pruning, particularly by test period, can be used to reveal spatial patterns in toxicity that otherwise might be obscured by excessive test-to-test variation (Loar 1994). When data for the March 1990 and May 1994 test periods were excluded from ANOVA, site, date, and the interaction term between site and date explained approximately $57.5 \%$ of the variation in Ceriodaphnia reproduction; and site, date, and the site-date interaction term remained highly significant ( $p<0.0001$ in each case). Data-pruning also resulted in a reordering of sites based on Duncan's Multiple Range Test: using the date-pruned data set, BCK 12.36, 11.83, and 9.91 were found to have Ceriodaphnia reproduction values that were significantly lower than those for the other sites (Table 3.5). This finding indicates that the results of the ANOVA for the full (i.e., non-pruned) data set were not being strongly affected by a few "outlier" results, and strongly supports the position that water in upper Bear Creek adversely affects Ceriodaphnia reproduction.

\subsubsection{Assessing Magnitude of Toxicity- Concentration - Response Patterns for Ceriodaphnia}

In three test periods - March 1990 , September 1990, and July 1992 - various 
Table 3.2. Results of fathead minnow and Ceriodaphnia tests of ambient water samples from various sites in Bear Creek

\begin{tabular}{|c|c|c|c|c|c|c|}
\hline \multirow[b]{2}{*}{ Test date } & \multirow[b]{2}{*}{$\begin{array}{l}\text { Water } \\
\text { source }\end{array}$} & \multirow[b]{2}{*}{$\begin{array}{l}\text { Conc. } \\
(\%)\end{array}$} & \multicolumn{2}{|c|}{ Pimephales promelas } & \multicolumn{2}{|c|}{ Ceriodaphnia dubia } \\
\hline & & & $\begin{array}{c}\text { Survival (\%) } \\
\text { (mean) }\end{array}$ & $\begin{array}{c}\text { Growth (mg/fish) } \\
(\text { mean } \pm \mathrm{SD})\end{array}$ & $\begin{array}{c}\text { Survival } \\
(\%)\end{array}$ & $\begin{array}{c}\text { Reproduction } \\
\text { (mean } \pm \text { SD) }\end{array}$ \\
\hline \multirow[t]{2}{*}{ Mar. 1, 1990} & Control & 100 & - & - & 90 & $18.3 \pm 2.4$ \\
\hline & BCK 12.36 & 100 & - & - & 0 & $\cdots \pm \cdots$ \\
\hline \multirow[t]{2}{*}{ Sept. 6, 1990} & Control & 100 & - & - & 80 & $22.8 \pm 6.7$ \\
\hline & BCK 12.36 & 100 & - & - & 0 & $-\cdots \pm \cdots$ \\
\hline \multirow[t]{7}{*}{ Oct. 31,1991} & Control & 100 & 92.5 & $0.55 \pm 0.03$ & 100 & $25.3 \pm 2.5$ \\
\hline & BCK 12.36 & 100 & 55.0 & $0.65 \pm 0.08$ & 0 & --- \pm-- \\
\hline & BCK 11.83 & 100 & 85.0 & $0.63 \pm 0.08$ & 30 & $3.0 \pm 3.5$ \\
\hline & BCK 11.09 & 100 & - & - & 0 & $\cdots \pm--$ \\
\hline & BCK 9.91 & 100 & 52.5 & $0.68 \pm 0.14$ & 100 & $20.4 \pm 3.9$ \\
\hline & BCK 9.40 & 100 & 87.5 & $0.60 \pm 0.05$ & 90 & $24.0 \pm 4.5$ \\
\hline & BCK 7.87 & 100 & 82.5 & $0.54 \pm 0.05$ & 100 & $26.3 \pm 4.9$ \\
\hline \multirow[t]{7}{*}{ July 30,1992} & Control & 100 & 100 & $0.51 \pm 0.01$ & 100 & $30.2 \pm 7.1$ \\
\hline & BCK 12.36 & 100 & 92.5 & $0.53 \pm 0.04$ & 0 & $\cdots \pm \cdots$ \\
\hline & BCK 11.83 & 100 & 97.5 & $0.60 \pm 0.06$ & 70 & $7.0 \pm 4.3$ \\
\hline & BCK 11.09 & 100 & 95.0 & $0.70 \pm 0.11$ & 100 & $35.8 \pm 5.6$ \\
\hline & BCK 9.91 & 100 & 95.0 & $0.59 \pm 0.16$ & 100 & $18.0 \pm 3.9$ \\
\hline & BCK 9.40 & 100 & 97.5 & $0.69 \pm 0.04$ & 100 & $22.6 \pm 10.8$ \\
\hline & BCK 7.87 & 100 & 82.5 & $0.64 \pm 0.07$ & 100 & $26.5 \pm 6.9$ \\
\hline \multirow[t]{5}{*}{ Sept. 15, 1992} & Control & 100 & - & - & 90 & $29.9 \pm 14.0$ \\
\hline & BCK 12.36 & 100 & - & - & 30 & $10.3 \pm 4.0$ \\
\hline & BCK 11.83 & 100 & - & - & 50 & $22.4 \pm 5.6$ \\
\hline & BCK 11.09 & 100 & - & - & 90 & $28.8 \pm 11.1$ \\
\hline & BCK 9.91 & 100 & - & - & 100 & $26.9 \pm 11.0$ \\
\hline \multirow[t]{5}{*}{ Jan. 14, 1993} & Control & 100 & 87.5 & $0.42 \pm 0.07$ & 100 & $27.9 \pm 3.1$ \\
\hline & BCK 12.36 & 100 & 90.0 & $0.63 \pm 0.06$ & 0 & $\cdots \pm \cdots$ \\
\hline & BCK 11.83 & 100 & 90.0 & $0.47 \pm 0.08$ & 20 & $2.5 \pm 2.1$ \\
\hline & BCK 11.09 & 100 & 87.5 & $0.48 \pm 0.09$ & 100 & $5.3 \pm 2.7$ \\
\hline & BCK 9.91 & 100 & 87.5 & $0.36 \pm 0.13$ & 100 & $23.1 \pm 9.5$ \\
\hline
\end{tabular}


Table 3.2 (continued)

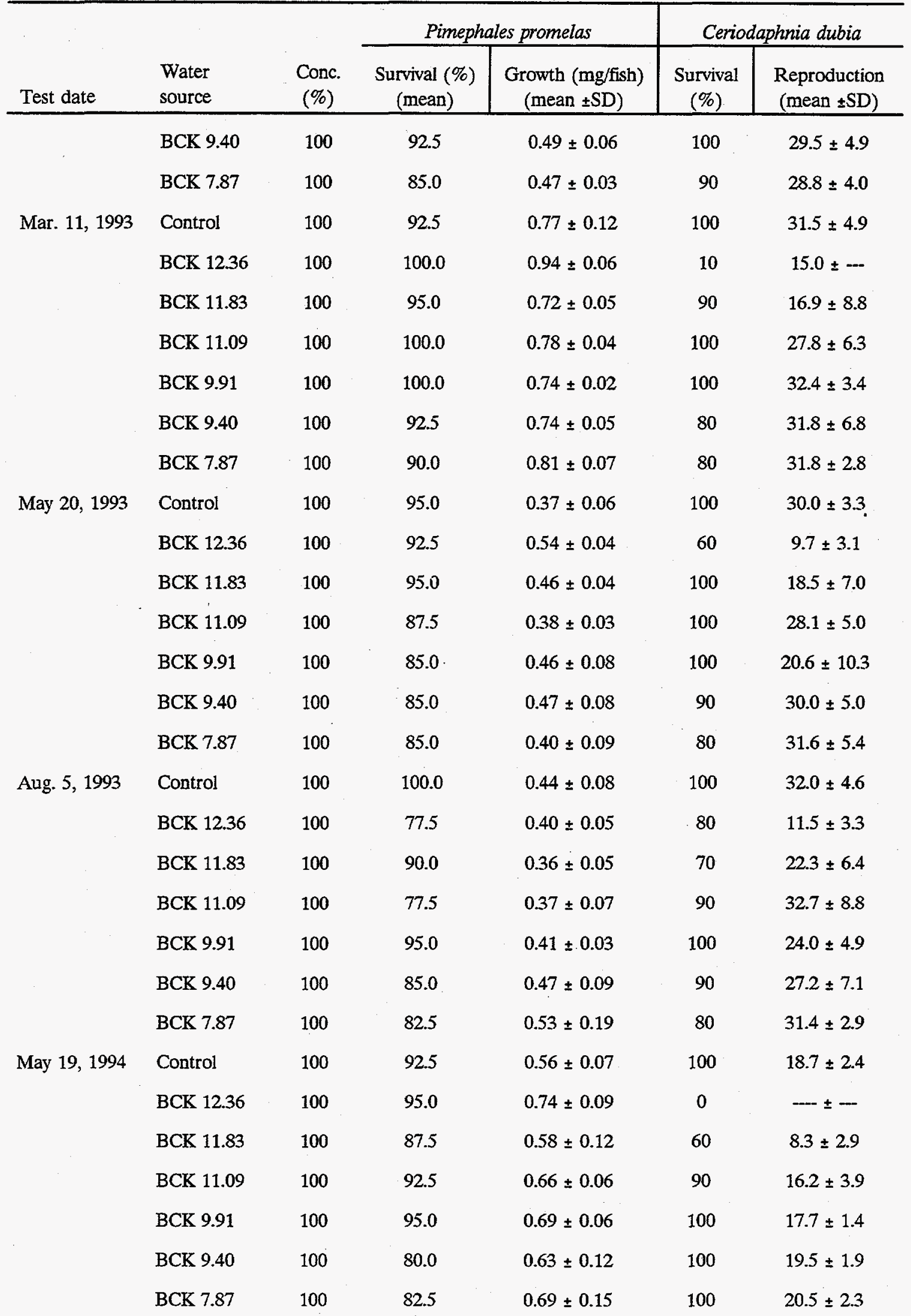


Table 3.2 (continued)

\begin{tabular}{llcc|c|c|c}
\hline & & & \multicolumn{2}{c}{ Pimephales promelas } & \multicolumn{2}{c}{ Ceriodaphnia dubia } \\
\cline { 5 - 7 } Test date & Water & Conc. & $\begin{array}{c}\text { Survival (\%) } \\
(\text { mean })\end{array}$ & $\begin{array}{c}\text { Growth (mg/fish) } \\
(\text { mean } \pm \text { SD) }\end{array}$ & $\begin{array}{c}\text { Survival } \\
(\%)\end{array}$ & $\begin{array}{c}\text { Reproduction } \\
(\text { mean } \pm \text { SD) }\end{array}$ \\
\hline Aug. 4, 1994 & Control & 100 & 97.5 & $0.71 \pm 0.08$ & 100 & $20.9 \pm 4.5$ \\
& BCK 12.36 & 100 & 95.0 & $0.77 \pm 0.05$ & 100 & $11.0 \pm 7.2$ \\
& BCK 11.83 & 100 & 85.0 & $0.79 \pm 0.06$ & 100 & $21.7 \pm 6.4$ \\
& BCK 11.83 & 100 & 100.0 & $0.73 \pm 0.05$ & 100 & $20.1 \pm 4.3$ \\
& BCK 11.09 & 100 & 97.5 & $0.72 \pm 0.05$ & 100 & $25.9 \pm 4.2$ \\
& BCK 9.91 & 100 & 92.5 & $0.69 \pm 0.11$ & 100 & $22.3 \pm 2.5$ \\
BCK 9.40 & 100 & 100.0 & $0.74 \pm 0.05$ & 100 & $23.1 \pm 3.1$ \\
BCK 7.87 & 100 & 85.0 & $0.78 \pm 0.06$ & 100 & $23.8 \pm 3.2$ \\
\hline
\end{tabular}

Note: " $-"$ refers to not tested; BCK = Bear Creek kilometer.

Table 3.3. Distribution of Ceriodaphnia survival values for ambient toxicity tests of water from six sites in Bear Creek (March 1, 1990, through May 26, 1994)

\begin{tabular}{lccccccc:cccccc}
\hline & \multicolumn{1}{c}{} & \multicolumn{1}{c}{ Ceriodaphnia survival (\%) } & & \\
& 0 & 10 & 20 & 30 & 40 & 50 & 60 & 70 & 80 & 90 & 100 & $\begin{array}{c}\text { Failure } \\
\text { frequency } \\
(\%)\end{array}$ \\
\hline Controls & 0 & 0 & 0 & 0 & 0 & 0 & 0 & 0 & 1 & 2 & 8 & 0 \\
BCK $^{b} 12.36$ & 6 & 1 & 0 & 1 & 0 & 0 & 1 & 0 & 1 & 0 & 1 & 81.8 \\
BCK 11.83 & 0 & 0 & 1 & 1 & 0 & 1 & 1 & 2 & 0 & 1 & 1 & 50.0 \\
BCK 11.09 & 1 & 0 & 0 & 0 & 0 & 0 & 0 & 0 & 0 & 3 & 5 & 11.1 \\
BCK 9.91 & 0 & 0 & 0 & 0 & 0 & 0 & 0 & 0 & 0 & 0 & 9 & 0 \\
BCK 9.40 & 0 & 0 & 0 & 0 & 0 & 0 & 0 & 0 & 1 & 3 & 4 & 0 \\
BCK 7.87 & 0 & 0 & 0 & 0 & 0 & 0 & 0 & 0 & 3 & 1 & 4 & 0 \\
\hline
\end{tabular}

${ }^{\circ}$ Tests in which Ceriodaphnia survival was $\leq 60 \%$ were classified as failing, based on a prior analysis of ambient test results of reference sites in headwater streams on the Oak Ridge Reservation (A. J. Stewart, 1994, Ambient bioassays for assessing water-quality conditions in receiving streams, Ecotoxicology (submitted). The dotted line shows the pass-or-fail boundary.

${ }^{b} \mathrm{BCK}=$ Bear Creek kilometer. 
Table 3.4. Mean reproduction of Ceriodaphnia in ambient toxicity tests of water from Bear Creek (March 1, 1990, through May 26, 1994)

\begin{tabular}{lccc}
\hline Site & $\begin{array}{c}\text { Number of } \\
\text { observations }\end{array}$ & $\begin{array}{c}\text { Mean reproduction } \\
\text { (offspring per surviving female) }\end{array}$ & Duncan grouping \\
\hline BCK 7.87 & 8 & 27.2 & $\mathrm{~A}$ \\
Controls & 11 & 26.1 & $\mathrm{~A}$ \\
BCK 9.40 & 8 & 25.2 & $\mathrm{~A}$ \\
BCK 11.09 & 8 & 25.0 & $\mathrm{~A}$ \\
BCK 9.91 & 9 & 22.9 & $\mathrm{~A}$ \\
BCK 11.83 & 9 & 13.6 & $\mathrm{~B}$ \\
BCK 12.36 & $6^{\mathrm{a}}$ & 8.5 & $\mathrm{~B}$ \\
\hline
\end{tabular}

${ }^{a}$ Only offspring from adults that survived all 7 days were used in this analysis. Thus, when survival of Ceriodaphnia was zero (as was common in tests of water from BCK 12.36), the number of observations was reduced.

Note: Sites with the same letter did not differ statistically from one another, based on ANOVA followed by Duncan's Multiple Range Test. In the ANOVA, site (including controls) explained $54.1 \%$ of the variation in mean reproduction ( $\mathrm{F}$ ratio $=10.21$, with $\mathrm{DF}_{6,52} ; p<0.0001$ ). $\mathrm{BCK}=\mathrm{Bear}$ Creek kilometer.

Table 3.5. Results of Duncan's Multiple Range Test applied to ANOVAs for both full and date-pruned data sets for Ceriodaphnia reproduction

\begin{tabular}{lccc}
\hline \multicolumn{1}{c}{ Site } & $\begin{array}{c}\text { Number of } \\
\text { observations }\end{array}$ & $\begin{array}{c}\text { Mean } \\
\text { reproduction }\end{array}$ & $\begin{array}{c}\text { Duncan's } \\
\text { groupings }\end{array}$ \\
\hline BCK 7.87 & \multicolumn{2}{c}{ Full Data Set } & \\
Control & 75 & 26.9 & $\mathrm{~A}$ \\
BCK 9.40 & 105 & 26.3 & $\mathrm{~A}$ \\
BCK 11.09 & 77 & 25.1 & $\mathrm{~A}$ \\
BCK 9.91 & 78 & 24.8 & $\mathrm{AB}$ \\
BCK 11.83 & 89 & 22.8 & $\mathrm{~B}$ \\
BCK 12.36 & 74 & 16.2 & $\mathrm{C}$ \\
& 46 & 8.1 & $\mathrm{D}$ \\
Contro1 & & & \\
BCK 7.87 & 86 & 28.0 & $\mathrm{~A}$ \\
BCK 11.09 & 65 & 27.9 & $\mathrm{~A}$ \\
BCK 9.40 & 68 & 26.2 & $\mathrm{~A}$ \\
BCK 9.91 & 67 & 26.0 & $\mathrm{~A}$ \\
BCK 11.83 & 79 & 23.5 & $\mathrm{~B}$ \\
BCK 12.36 & 64 & 17.4 & $\mathrm{C}$ \\
\hline
\end{tabular}

${ }^{a}$ Pruning accomplished by excluding reproduction data for tests conducted during March 1990 and May 1994. 
dilutions of water from BCK 12.36 were tested. In the first of these three test periods, the concentrations that were tested included $10 \%, 20 \%, 40 \%, 60 \%$, $80 \%$, and $100 \%$ of full-strength. In the September 1990 test period, three concentrations $(25 \%, 50 \%$, and $100 \%)$ were tested, and in the July 1992 test period, only two concentrations (50\% and $100 \%$ ) were tested. In the second test period, Ceriodaphnia survival was zero in all three tested concentrations. Thus, in the second test period, water from BCK 12.36 had a NOEC that was $<25 \%$. During the July 1992 test period, survival was zero in full-strength water from BCK 12.36 but moderately high (80\%) in a $50 \%$-concentration of the ambient water. Full dose-response curves for Ceriodaphnia survival and reproduction were revealed by the dilution series used during the March 1990 test period. These curves are shown in Fig. 3.2. The dose-response curves were used to estimate the toxicity of $\mathrm{BCK} 12.36$ water. By application of ANOVA and Dunnett's test, the water's NOEC was found to be $10 \%$. The water's toxicity was also estimated by deternuning the concentration needed to lower the reproduction of the daphnids to a mean of 15 offspring per female $\left(\mathrm{SR}_{15}\right.$; see Griest et al. 1993); the water's $S_{15}$ was $16.3 \%$.

\subsubsection{Fathead Minnow Toxicity Test Results - Survival and Growth}

Survival and growth data from the fathead minnow tests, both including and excluding data from the controls, were analyzed by two-way ANOVA, using site and date as explanatory factors. The results of the ANOVAs of survival data showed that the effect of site diminished with removal of the controls (the $P$ value for site increased from 0.029 to 0.207 ); the site-date interaction term remained significant $(p<0.05)$ in both cases
(Table 3.6). The ANOVAs for minnow growth data (with controls included and controls excluded) showed that the effect of site was reduced (but not rendered statistically insignificant) by excluding data for controls. Minnow growth clearly was affected by site, but the effect of date was much greater than that of site (Table 3.7). Mean growth of the minnow larvae for the six Bear Creek sites (all test results pooled by date) ranged from $0.579 \mathrm{mg} /$ fish at BCK 9.91 to $0.649 \mathrm{mg}$ /fish at BCK 12.36 . The difference between these two means, expressed as a percentage of the overall mean growth of minnows in the controls, was $12.5 \%$. Thus, differences in minnow growth within Bear Creek tended to be small. The significant site-date interaction term (Table 3.7) for minnow growth, both when controls were included and excluded from consideration, also suggested that the effects of site on minnow growth differed through time.

\subsubsection{Ceriodaphnia and Fathead Minnow Tests of Tributary Sites in Bear Creek}

The results of the two sets of tests, conducted in May and August 1994, are provided in Tables 3.8 and 3.9. Five of the sites showed evidence of toxicity during May; three sites were toxic during August. All of the evidence for toxicity noted during these two test periods was based on Ceriodaphnia survival (four sites during the May tests) or Ceriodaphnia reproduction (five sites during the May tests, three sites during the August tests). The pattern noted in the results of these tests suggested that Ceriodaphnia reproduction was more sensitive than Ceriodaphnia survival as an indicator of ambient water quality and that Ceriodaphnia was more sensitive than fathead minnows. This pattern is similar to that in other studies that have compared Ceriodaphnia and 


\section{BCK 12.36}

\section{March 1990}
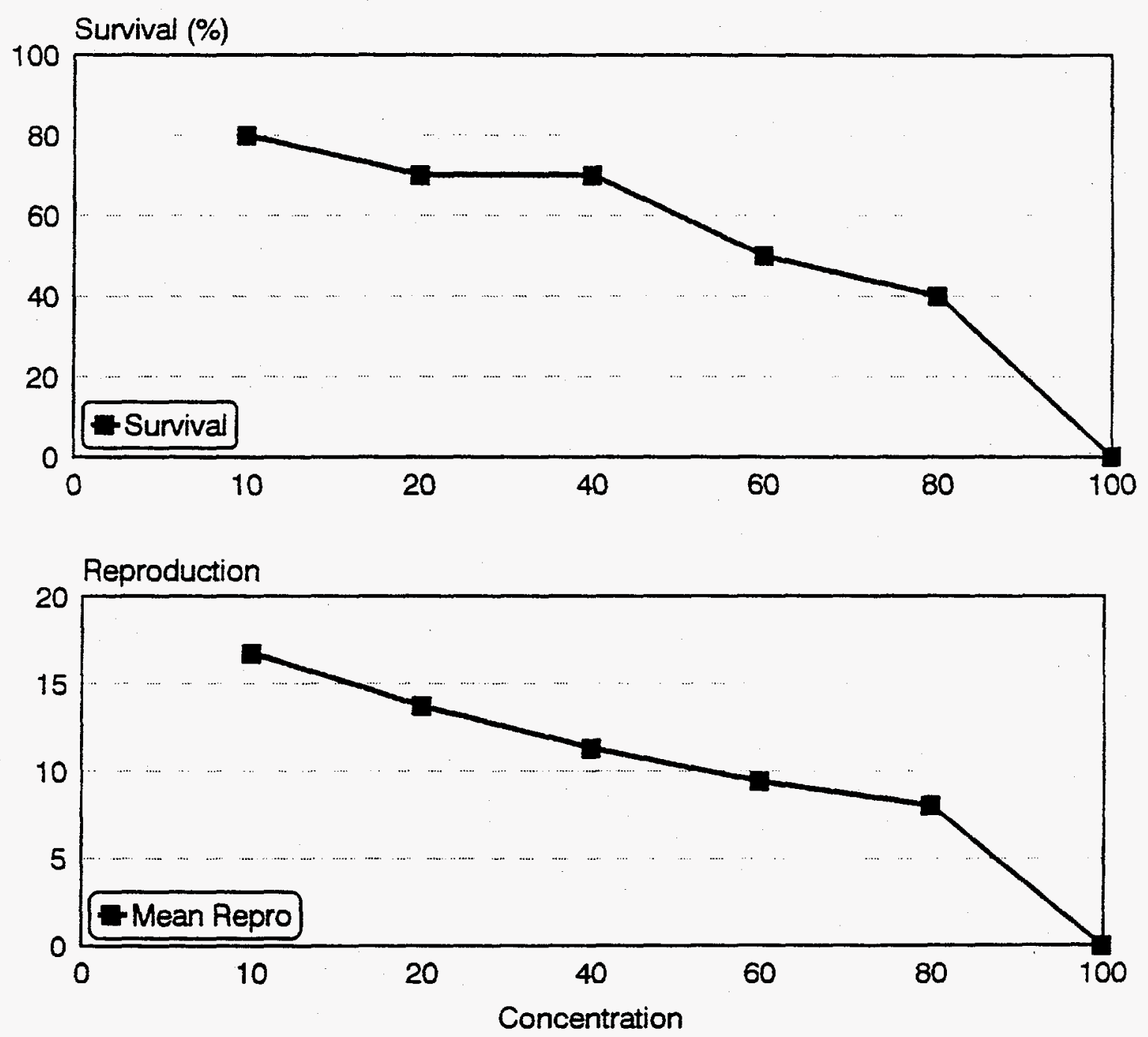

Fig. 3.2. Concentration-response curves for Ceriodaphnia survival (top) and reproduction (bottom) in water from Bear Creek kilometer 12.36 during March 1990. 
Table 3.6. Results of two-way ANOVAs for fathead minnow survival (arc-sine square-root transformed percentage) with data for controls included (left) and excluded (right)

\begin{tabular}{lccc:ccc}
\hline & \multicolumn{3}{c}{ Data for controls included } & \multicolumn{3}{c}{ Data for controls excluded } \\
\cline { 2 - 7 } \multicolumn{1}{c}{ Source of variation } & DF & F ratio & $p$ value & DF & F ratio & $p$ value \\
\hline Full model & 54 & 2.17 & $<0.0001$ & 46 & 2.17 & 0.0002 \\
$\quad$ Site & 6 & 2.41 & 0.0292 & 5 & 1.46 & 0.2069 \\
$\quad$ Date & 7 & 5.40 & $<0.0001$ & 7 & 5.68 & $<0.0001$ \\
$\quad$ Site-date interaction & 41 & 1.60 & 0.0210 & 34 & 1.56 & 0.0381 \\
Error & 169 & & & 145 & & \\
Total & 223 & & & 191 & & \\
\hline
\end{tabular}

${ }^{\circ} \mathrm{SAS}$ general linear models procedure, type III sum of squares.

Note: Full models explained approximately $40.9 \%$ and $40.8 \%$ of the variation in minnow survival when controls were included and excluded respectively.

Table 3.7. Results of two-way ANOVAs for fathead minnow growth with data for controls included (left) and excluded (right)

\begin{tabular}{lccc:ccc}
\hline & \multicolumn{3}{c}{ Data for controls included } & \multicolumn{3}{c}{ Data for controls excluded } \\
\cline { 2 - 7 } \multicolumn{1}{c}{ Source of variation } & DF & F ratio & $p$ value & DF & F ratio & $p$ value \\
\hline Full model & 54 & 12.13 & $<0.0001$ & 46 & 12.02 & $<0.0001$ \\
$\quad$ Site & 6 & 4.43 & 0.0003 & 5 & 2.92 & 0.0153 \\
$\quad$ Date & 7 & 74.65 & $<0.0001$ & 7 & 66.12 & $<0.0001$ \\
$\quad$ Site-date interaction & 41 & 2.38 & $<0.0001$ & 34 & 2.22 & 0.0006 \\
Error & 168 & & & 145 & & \\
Total & 222 & & & 191 & & \\
\hline
\end{tabular}

aSAS general linear models procedure, type III sum of squares.

Note: Full models explained approximately $79.6 \%$ and $79.2 \%$ of the variation in minnow growth when controls were included and excluded respectively.

fathead minnow tests in ambient applications (cf. Stewart et al. 1990). In both test periods, field-split samples were tested with both species. The maximum difference among Ceriodaphnia test outcomes for the two site-date combinations that used split-sample analysis was $7.9 \%$ (reproduction, during the August tests); the maximum difference among fathead minnow test outcomes was $19.4 \%$ (growth, during the May tests). This finding lends additional credence to the idea that Ceriodaphnia tests may be more reliable than fathead minnowtests in ambient water-quality assessments. 
Table 3.8. Fathead minnow survival and mean growth and Ceriodaphnia survival and mean reproduction in water from various sites in Bear Creek (including tributaries) and reference sites for 7-d tests conducted during May 19-26, 1994

\begin{tabular}{|c|c|c|c|c|}
\hline Site $^{a}$ & $\begin{array}{l}\text { Fathead minnow } \\
\text { survivai }(\%)\end{array}$ & $\begin{array}{l}\text { Fathead minnow } \\
\text { growth (mg/fish) }\end{array}$ & $\begin{array}{l}\text { Ceriodaphnia } \\
\text { survival (\%) }\end{array}$ & $\begin{array}{l}\text { Ceriodaphnia } \\
\text { reproduction }\end{array}$ \\
\hline Control & 92.5 & 0.56 & 100 & 18.7 \\
\hline NT 1 & 97.5 & 0.78 & 0 & 1.1 \\
\hline BCK 12.36 & 95.0 & 0.74 & 0 & 1.2 \\
\hline SS 1 & 70.0 & 0.79 & 60 & 8.9 \\
\hline NT 2 & 97.5 & 0.69 & 100 & 11.7 \\
\hline NT 3 & 77.5 & 0.64 & 100 & 16.2 \\
\hline BCK 11.83 & 87.5 & 0.58 & 60 & 8.4 \\
\hline NT 4 & 82.5 & 0.67 & 100 & 17.3 \\
\hline NT 5 & 97.5 & 0.65 & 100 & 16.0 \\
\hline BCK 11.09 & 92.5 & 0.66 & 90 & 15.7 \\
\hline SS $4-A^{b}$ & 97.5 & 0.62 & 100 & 15.0 \\
\hline SS $4-B^{b}$ & 97.5 & 0.74 & 90 & 15.8 \\
\hline NT 6 & 90.0 & 0.73 & 90 & 17.7 \\
\hline BCK 9.91 & 95.0 & 0.69 & 100 & 17.7 \\
\hline NT 7 & 82.5 & 0.51 & 100 & 19.4 \\
\hline NT 8 & 95.0 & 0.62 & 100 & 20.1 \\
\hline BCK 9.40 & 80.0 & 0.63 & 100 & 19.5 \\
\hline SS 5 & 100 & 0.59 & 100 & 20.2 \\
\hline BCK 7.87 & 82.5 & 0.69 & 100 & 20.5 \\
\hline SS 6 & 95.0 & 0.57 & 100 & 19.4 \\
\hline BCK 3.25 & 100 & 0.57 & 100 & 23.3 \\
\hline SS 8 & 92.5 & 0.59 & 100 & 19.3 \\
\hline HCK $12.9^{c}$ & 87.5 & 0.60 & 90 & 23.4 \\
\hline
\end{tabular}
kilometer.

${ }^{a} \mathrm{NT}=$ North tributary; BCK $=$ Bear Creek kilometer; SS $=$ South Spring, HCK $=$ Hinds Creek

${ }^{b}$ Field split sample.

${ }^{c}$ Hinds Creek reference site.

Note: Boxes enclose values that could indicate toxicity, compared with expected distributions for Ceriodaphnia survival (A. J. Stewart 1994) or reproductive capacity ( $\mathrm{SR}_{15}$ limits; W. H. Griest, A. J. Stewart, R. L. Tyndall, J. E. Canton, C.-h Ho, K. S. Ironside, W. M. Caldwell, and E. Tan, 1993, Chemical and toxicological testing of composed explosives-contaminated soil, Environ. Toxicol. Chem. 12:1105-1116). 
Table 3.9. Fathead minnow survival and mean growth and Ceriodaphnia survival and mean reproduction in water from various sites in Bear Creek (including tributaries) and reference sites for 7-d tests conducted during August 4-10, 1994

\begin{tabular}{|c|c|c|c|c|}
\hline Site $^{a}$ & $\begin{array}{l}\text { Fathead minnow } \\
\text { survival (\%) }\end{array}$ & $\begin{array}{l}\text { Fathead minnow } \\
\text { growth (mg/fish) }\end{array}$ & $\begin{array}{l}\text { Cerioaaphnia } \\
\text { survival (\%) }\end{array}$ & $\begin{array}{l}\text { Ceriodaphnia } \\
\text { reproduction }\end{array}$ \\
\hline Control & 97.5 & 0.71 & 100 & 20.9 \\
\hline NT 1 & 92.5 & 0.73 & 100 & 18.4 \\
\hline BCK 12.36 & 95.0 & 0.77 & 100 & 11.0 \\
\hline SS 1 & 97.5 & 0.79 & 90 & 11.4 \\
\hline NT 2 & 90.0 & 0.79 & 100 & 19.0 \\
\hline NT 3 & 95.0 & 0.75 & 100 & 22.5 \\
\hline BCK $11.83-\mathrm{A}^{b}$ & 85.0 & 0.80 & 100 & 21.7 \\
\hline $\mathrm{BCK} 11.83-\mathrm{B}^{b}$ & 100 & 0.73 & 100 & 20.1 \\
\hline NT 4 & 97.5 & 0.76 & 100 & 26.1 \\
\hline NT 5 & 95.0 & 0.79 & 100 & 26.1 \\
\hline BCK 11.09 & 97.5 & 0.72 & 100 & 25.9 \\
\hline SS 4 & 77.5 & 0.73 & 80 & 14.8 \\
\hline NT 6 & 97.5 & 0.72 & 100 & 22.2 \\
\hline BCK 9.91 & 92.5 & 0.69 & 100 & 22.3 \\
\hline NT 7 & 90.0 & 0.75 & 100 & 22.3 \\
\hline NT 8 & 95.0 & 0.75 & 100 & 21.1 \\
\hline BCK 9.40 & 100 & 0.74 & 100 & 23.1 \\
\hline SS 5 & 95.0 & 0.75 & 100 & 20.2 \\
\hline BCK 7.87 & 85.0 & 0.78 & 100 & 23.8 \\
\hline SS 6 & 95.0 & 0.71 & 100 & 23.1 \\
\hline BCK 3.25 & 95.0 & 0.75 & 90 & 24.3 \\
\hline SS 8 & 90.0 & 0.62 & 100 & 22.5 \\
\hline HCK $12.9^{c}$ & 80.0 & 0.77 & 100 & 26.1 \\
\hline
\end{tabular}

${ }^{a} \mathrm{NT}=$ North tributary; $\mathrm{BCK}=$ Bear Creek kilometer; $\mathrm{SS}=$ South spring; HCK $=$ Hinds Creek kilometer.

${ }^{b}$ Field split sample.

${ }^{b}$ Hinds Creek reference site.

Note: Boxes enclose values that could indicate toxicity, compared with expected distributions for Ceriodaphnia survival (A. J. Stewart 1994) or reproductive capacity $\left(\mathrm{SR}_{15}\right.$ limits; W. H. Griest, A. J. Stewart, R. L. Tyndall, J. E. Canton, C.-h Ho, K. S. Ironside, W. M. Caldwell, and E. Tan 1993, Chemical and toxicological testing of composed explosives-contaminated soil, Environ. Toxicol. Chem. 12:1105-1116). 


\subsubsection{Longitudinal Patterns in Biological Quality of the Water in Bear Creek}

Longitudinal patterns in biological quality of the water in Bear Creek were evident based on the responses of Ceriodaphnia, both in terms of survival and reproduction (Tables 3.3, 3.4, and 3.5). No such patterns were evident based on the results of the fathead minnow tests, based either on survival or growth. Additionally, the range in mean survival of minnow larvae among the six Bear Creek sites was small $(89.2 \%$ at BCK 7.87 to $96.4 \%$ at BCK 11.83; back-transformed data) compared with the range in mean survival for Ceriodaphnia (51.8\% at BCK 12.36 to $98.9 \%$ at BCK 9.91). The range in fish mean growth was also small $(0.58 \mathrm{mg} /$ fish at BCK 9.91 to $0.65 \mathrm{mg} /$ fish at $B C K$ 12.36) compared with the range in mean reproduction for Ceriodaphnia (8.1 offspring per female at BCK 12.36 and 26.9 offspring per female at BCK 7.87). These considerations support the contention that more frequent testing with Ceriodaphnia only may be more advantageous (in terms of information gained per dollar spent) than less frequent testing with both speciss.

\subsubsection{Temporal Changes in Biological Quality of the Water in Bear Creek}

Temporal changes in water quality of upper Bear Creek were evaluated by use of a mean reproduction criterion of 15 offspring per female $\left(\mathrm{SR}_{15}\right)$. This criterion has been used to quantify toxicity of aqueous solutions to Ceriodaphnia (Griest et al. 1993). A fixed-value criterion such as the $\mathrm{SR}_{15}$ is useful in ambient applications because it excludes consideration of test-to-test variation in reproduction, and makes no direct statistical comparison to a control or a reference site: it only specifies a biologically based lower-bound limit to Ceriodaphnia reproduction, below which water quality conditions are likely to be suspect. EPA's reproduction criterion for a satisfactory control when using Ceriodaphnia to estimate effluent toxicity is 15 offspring per female. Thus, the $\mathbf{S R}_{15}$ criterion is compatible with acceptability limits imposed by EPA. The $\mathrm{SR}_{15}$ criterion was applied to Ceriodaphnia toxicity test results for ten test periods (from March 1988 through May 1994) when data were available for four sites (BCK 12.36, 11.83, 11.09, and 9.91). In each test period, we used graphic interpretation to determine how far downstream from BCK 12.36 one would need to be, theoretically, to obtain water samples with biological quality high enough to allow Ceriodaphnia to produce 15.0 offspring per surviving female. The expectation was that as conditions improved in upper Bear Creek through time, the $\mathrm{SR}_{15}$ position in the stream would shift upstream closer and closer to $\mathrm{BCK}$ 12.36 , assumed to be the "zero point" for poor water quality. The result of this analysis is shown in Fig. 3-3.

\subsubsection{Presence of Snails (Elimia) in Upper Bear Creek}

Studies conducted in Bear Creek during December 1986 and January and February 1987 showed that Elimia (a snail that is abundant in many streams on the Oak Ridge Reservation) moved downstream when placed into the water near BCK 12.36 (Burris et al. 1990). At that time, Elimia was not present in mainstem segments of Bear Creek upstream of BCK 9.4, but was present farther downstream (e.g., near BCK 3.25) and in several north-flowing tributaries (e.g., ST2 and ST3). In a cursory survey conducted during July 1994, adult and juvenile Elimia were noted in Bear Creek as far upstream 


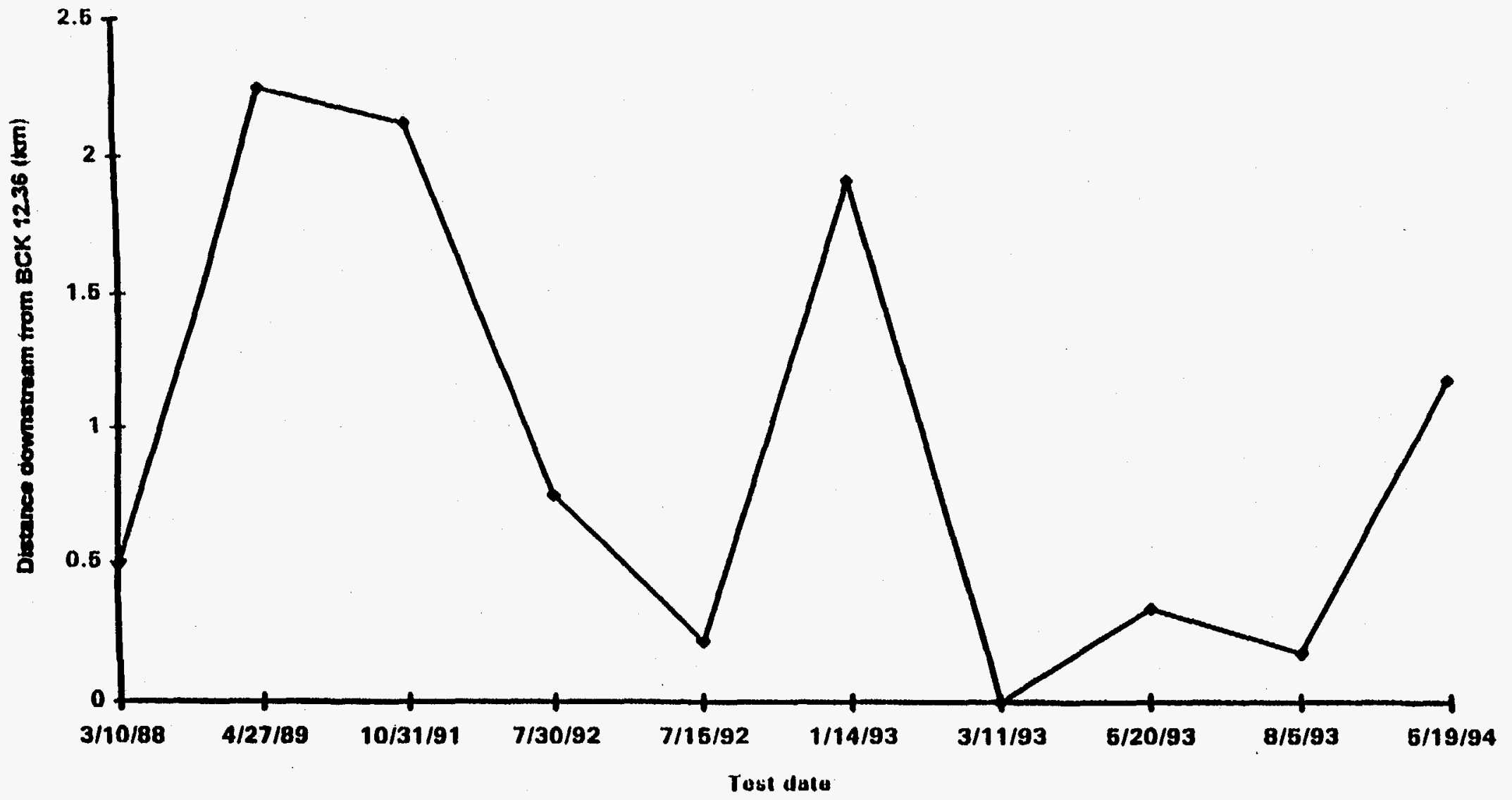

Fig. 3.3. Temporal changes in location of the "toxic threshold" position in upper Bear Creek. In this analysis, toxicity is based on $\mathrm{SR}_{15}$ values for Ceriodaphnia, and position of the $\mathrm{SR}_{15}$ point is interpolated spatially [expressed as kilometer downstream from Bear Creek kilometer (BCK) 12.36], based on data for BCK 12.36, 11.83, and 11.09 . 
as BCK 11.83, albeit in low abundance (W. R. Hill and A. J. Stewart, Environmental Sciences Division). This finding provides evidence for the idea that water quality conditions in upper Bear Creek are improving.

\subsubsection{Chemical Water-Quality Measurements}

In each test period, daily grab samples of water were collected from each of the Bear Creek sites being tested for toxicity. Portions of these samples were analyzed for $\mathrm{pH}$, conductivity, aikalinity, and hardness. Summary statistics for measurements of these parameters are provided in Table 3.10 .

Levels of conductivity, alkalinity, and hardness in Bear Creek declined consistently with distance downstream from BCK 12.36 (Table 3.10). The relative magnitudes of decreases of conductivity, hardness, and alkalinity, from BCK 12.36 to BCK 7.87, were 2.64-fold, 1.22 -fold, and 2.44 -fold respectively. The mean levels of conductivity and hardness at BCK 12.36 and 11.83 were high compared with those reported for other chemically perturbed streams on ORR (Table 3.11). The variability in conductivity and hardness at BCK 12.36 and 11.83 [expressed as the coefficient of variation (CV), which accounts for differences in levels] was also large, compared both with sites farther downstream in Bear Creek (Fig. 3.4) and with sites in other streams on ORR (Table 3.11).

\subsection{DISCUSSION}

\subsubsection{Longitudinal and Temporal Patterns in Ambient Toxicity}

Despite remedial actions such as closing of the S-3 Ponds, sites in upper
Bear Creek continue to show evidence of toxicity to Ceriodaphnia; no strong evidence for acute or chronic toxicity is evident based on the results of tests with fathead minnow larvae. In cases where evidence for toxicity has been found, it generally appears to be restricted to BCK 12.36 and 11.83. The present distribution of Elimia in Bear Creek, showing gradual reinvasion of the stream near BCK 11.83 , provides additional evidence for the idea that biological quality of water in upper Bear Creek is improving.

We attempted to determine whether biological water-quality conditions in upper Bear Creek have improved through time, by inspecting $\mathrm{SR}_{15}$ locations in Bear Creek since toxicity testing began in 1988 . This analysis showed that the $\mathrm{SR}_{15}$ location has been as far as $2.25 \mathrm{~km}$ downstream from BCK 12.36 (e.g., in April 1989). No clear pattern of recovery through time, though, was evident (Fig. 3.3). Future improvements in water-quality conditions at $\mathrm{BCK} 12.36$ and 11.83 are expected; these improvements should be revealed by testing with Ceriodaphnia, with gradual stabilization of the $\mathrm{SR}_{15}$ position at BCK 12.36 .

\subsubsection{Temporal Patterns in Chemical Water-Quality Conditions in Upper Bear Creek}

High levels of calcium, sometimes in excess of $300 \mathrm{mg} / \mathrm{L}$, have been found in upper Bear Creek (note Appendix A). Elevated concentrations of this constituent are due to prior disposal practices, which included release of acidic wastes into the unlined S-3 Ponds. Prior studies have shown that calcium at concentrations in excess of about $115 \mathrm{mg} / \mathrm{L}$ can be toxic to Ceriodaphnia (Kszos and Taylor 1992a). Thus, some consideration is given to the idea that calcium may cause or contribute 
Table 3.10. Summary statistics of water quality factors for Bear Creek ambient toxicity testing sites

\begin{tabular}{ccccc}
\hline & \multicolumn{4}{c}{ Chemical Parameters } \\
\cline { 2 - 5 } Sites $^{a}$ & $\mathrm{pH}$ & $\begin{array}{c}\text { Conductivity } \\
(\mu / \mathrm{cm})\end{array}$ & $\begin{array}{c}\text { Alkalinity } \\
\left(\mathrm{mg} \mathrm{CaCO}_{3}\right)\end{array}$ & $\begin{array}{c}\text { Hardness } \\
\left(\mathrm{mg} \mathrm{CaCO}_{3}\right)\end{array}$ \\
\hline BCK 12.36 & $7.92(3.4)$ & $1388.7(57.5)$ & $207.7(34.3)$ & $631.7(69.4)$ \\
& $7.71-8.34$ & $341-3360$ & $62-350$ & $102-1800$ \\
BCK 11.83 & $7.99(2.2)$ & $1311.1(35.9)$ & $184.7(31.4)$ & $606.6(59.9)$ \\
& $7.51-8.24$ & $366-2280$ & $68-480$ & $136-2000$ \\
BCK 11.09 & $8.09(1.7)$ & $547.4(29.1)$ & $135.3(19.7)$ & $240.9(26.9)$ \\
& $7.84-8.31$ & $270-896$ & $63-248$ & $120-352$ \\
BCK 9.91 & $8.08(2.2)$ & $749.7(29.5)$ & $196.9(24.5)$ & $340.7(27.6)$ \\
& $7.67-8.39$ & $325-1150$ & $81-258$ & $154-500$ \\
BCK 9.40 & $8.00(3.0)$ & $554.9(18.4)$ & $174.8(18.9)$ & $266.5(18.0)$ \\
& $7.43-8.40$ & $329-726$ & $77-215$ & $138-344$ \\
BCK 7.87 & $8.17(0.16)$ & $525.1(19.4)$ & $170.4(18.7)$ & $258.4(18.5)$ \\
& $7.76-8.49$ & $313-682$ & $84-207$ & $154-350$ \\
\hline
\end{tabular}

${ }^{\lrcorner} \mathrm{BCK}=$ Bear Creek kilometer.

Note: Values are means, coefficient of variation of the mean (in parentheses), and ranges. Data are for daily grab samples for $7-d$ test periods.

to ambient toxicity in upper Bear Creek, and to assessing changes in conditions that affect calcium concentriations in the stream.

Based on hardness data obtained in association with toxicity testing (Tables 3.10, 3.11), mean concentrations of calcium in water from BCK 12.36 and BCK 11.83 were estimated to be 194 and $202 \mathrm{mg} / \mathrm{L}$ respectively, assuming that $80 \%$ of the hardness-causing constituents are calcium. These concentrations, with their attendant variation, indicate that water from BCK 12.36 and BCK 11.83 could frequently be toxic to Ceriodaphnia even when diluted to $60 \%$ of full strength, and sometimes toxic when diluted to a concentration as low as $17.9 \%$ of full strength. Such considerations suggest that calcium could be an important contributor or cause of ambient toxicity in upper Bear Creek, as determined through application of Ceriodaphnia toxicity tests.
In many freshwater lakes and streams, concentrations of dissolved calcium are at equilibrium with carbonate or bicarbonate anions, the proportions and quantities of which are altered by changes in concentration of dissolved $\mathrm{CO}_{2}$. In such cases, calcium can behave nonconservatively: concentrations of dissolved $\mathrm{CO}_{2}$ are affected strongly both by water temperature and biological processes such as photosynthesis (Kelts and Hsu 1978, Stewart 1988), and if concentrations of dissolved $\mathrm{CO}_{2}$ decline, calcium precipitates from solution, usually in the form of carbonates. In Bear Creek, the concentration of calcium would be expected to decline with distance downstream due to a combination of precipitation and dilution. Precipitation of calcium could predominate over dilution, especially during warmer periods of the year, if the anions available to support 
Table 3.11. Mean (coefficient of variation) levels of conductivity, alkalinity, and hardness for water samples from various sites in selected streams on the Oak Ridge Reservation

\begin{tabular}{lcccccc}
\hline Stream & \multicolumn{1}{c}{ Site $^{a}$} & Reference $^{b}$ & Condition $^{c}$ & $\begin{array}{c}\text { Conductivity }^{d} \\
\text { (mean, CV) }\end{array}$ & $\begin{array}{c}\text { Hardness }^{e} \\
\text { (mean, CV) }\end{array}$ & $\begin{array}{c}\text { Alkalinity }^{e} \\
(\text { mean, CV) }\end{array}$ \\
\hline Bear Creek & BCK 12.36 & 1 & A & $1389(57.5)$ & $632(69.4)$ & $208(34.3)$ \\
Bear Creek & BCK 11.83 & 1 & A & $1311(36.0)$ & $697(59.9)$ & $185(31.4)$ \\
Bear Creek & BCK 7.87 & 1 & B & $525(19.4)$ & $258(18.5)$ & $170(18.7)$ \\
East Fork Poplar Creek & EFK 24.6 & 2 & A & $552(33.8)$ & $107(13.8)$ & $199(21.7)$ \\
East Fork Poplar Creek & EFK 10.9 & 2 & B & $435(10.6)$ & $129(9.9)$ & $174(11.3)$ \\
White Oak Creek & WCK 6.8 & 3 & C & $186(35.5)$ & $115(36.1)$ & $96(45.1)$ \\
White Oak Creek & WCK 3.4 & 3 & B & $330(20.3)$ & $148(15.4)$ & $108(11.5)$ \\
McCoy Branch & MCK 2.03 & 4 & B & $184(25.4)$ & $104(15.3)$ & $62(22.6)$ \\
\hline
\end{tabular}

${ }^{a} \mathrm{BCK}=$ Bear Creek kilometer; EFK = East Fork Poplar Creek kilometer; WCK = White Oak Creek kilometer; MCK = McCoy Branch kilometer.

${ }^{b}$ Reference codes are: (1) present study; (2) R. L. Hinzman, 1993, Second Report on the Oak Ridge Y-12 Plant Biological Monitoring and Abatement Program for East Fork Poplar Creek, Y/TS-888, Oak Ridge National Laboratory, Oak Ridge, Tennessee; (3) T. A. Ashwood, 1994, Seventh annual report on the ORNL Biological Monitoring and Abatement Program, Draft ORNL/TM, Oak Ridge National Laboratory, Oak Ridge, Tennessee; and (4) A. J. Stewart, W. R. Hill, K. D. Ham, S. W. Christensen, and J. J. Beauchamp, 1994, Chlorine dynamics and ambient toxicity in receiving streams, Ecol. Appl. (in revision) (unpublished data for McCoy Branch report).

${ }^{\circ}$ Condition refers to degree of impact at the site (best professional judgement), based on biological and water-quality data from Biological Monitoring and Abatement Program studies. "A" designates high-impact conditions; B designates moderate to low impact conditions; and $\mathrm{C}$ designates non-polluted reference sites presumed to represent background conditions for headwater streams.

${ }^{d}$ Means are given in microseimens per centimeter, rounded to the nearest whole number.

${ }^{e}$ Means are given in milligrams per liter $\left(\mathrm{CaCO}_{3}\right)$, rounded to the nearest whole number. 
ORNL-DWG 96-3540

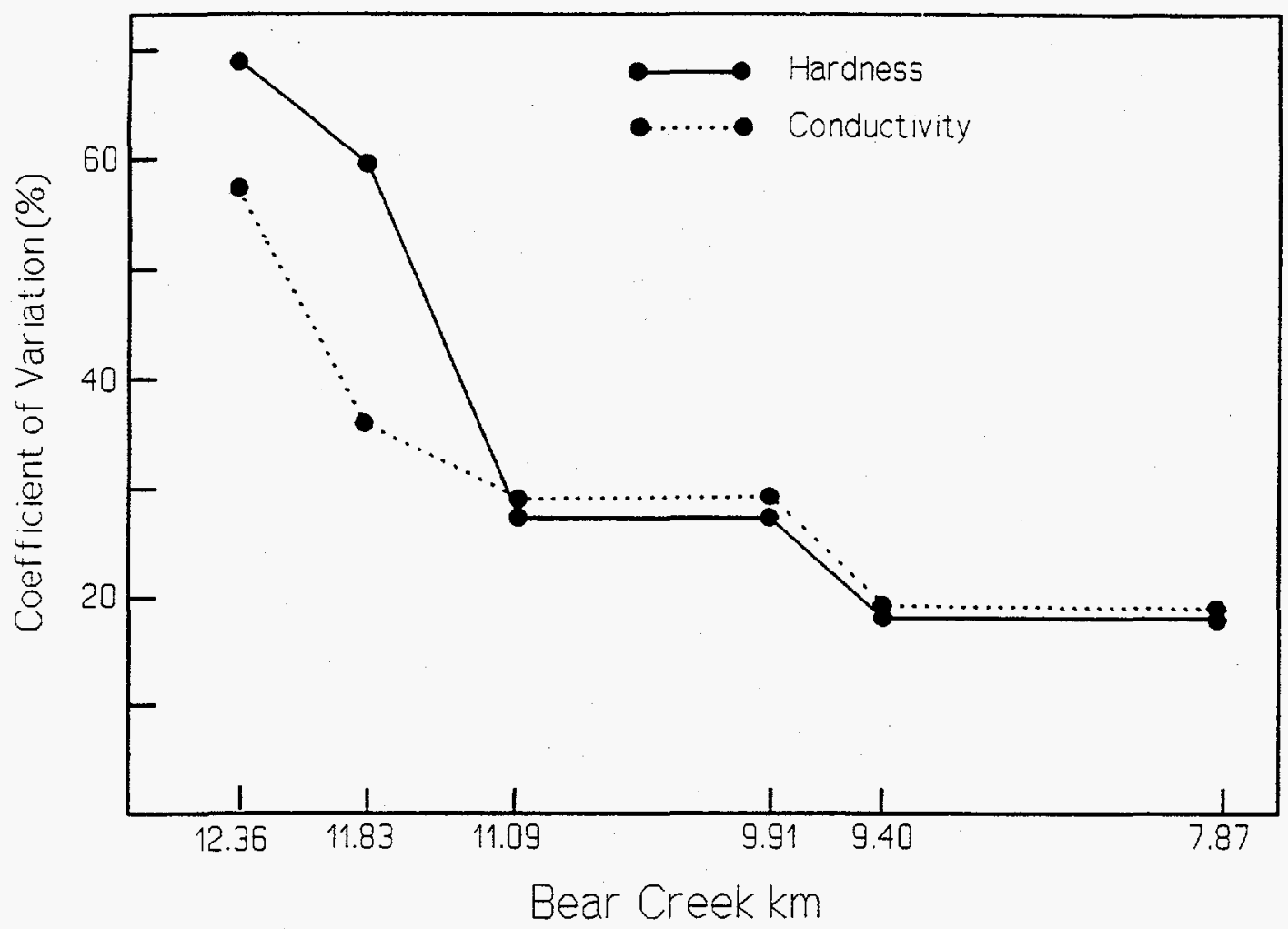

Fig. 3.4. Coefficients of variation for hardness and conductivity for water samples from various sites in Bear Creek

calcium are dominated by carbonate and bicarbonate. Alternatively, calcium can be held in solution if balanced by nitrate $\left(\mathrm{NO}_{3}{ }^{-1}\right)$. Nitrate-supported calcium could also be available for precipitation if the nitrate is lost through denitrification. In short, the types of controls on calcium in solution depend upon the kinds of anions available to hold calcium in solution, and the losses of calcium from solution are likely to be of toxicological significance.

Partial ion balances for two sites in upper Bear Creek were developed to explore this situation. This balance used mean measured calcium and nitrate values for BCK 11.97 and 12.4 for 1990-94 (Appendix A), and mean annual alkalinity and conductivity values for BCK 11.83 and 12.36 , measured in conjunction with ambient toxicity tests. The amounts of calcium that could be supported in solution, theoretically, by nitrate and carbonate, were compared to the mean measured amounts of calcium at each site (Tables 3.12 and 3.13).

Data in Tables 3.12 and 3.13 reveal the following points. First, concentrations of calcium in Bear Creek near BCK 11.83 and BCK 12.36 have declined from 1990 to present. The magnitude of these declines have been on the order of $14 \%$ at BCK 12.36 , and $41 \%$ at BCK 11.83 . Presently, the calcium levels at these two sites are similar $(3.57 \mathrm{mM}$ at $\mathrm{BCK} 11.83$, $3.68 \mathrm{mM}$ at BCK 12.36). Extrapolating from decline rates for calcium since 1990 , it appears that mean concentrations of this cation should be below levels that are toxic to Ceriodaphnia at BCK 11.83 by the end of 1995, and at or below toxic levels at BCK 12.36 by the end of 1998 . 
Table 3.12. Levels of calcium in relation to nitrate, alkalinity, and conductivity in BCK 11.97-11.83

\begin{tabular}{lccccc}
\hline Condition & 1990 & 1991 & 1992 & 1993 & 1994 \\
\hline Calcium present $(\mathrm{mM})^{a}$ & 6.05 & 5.97 & 5.37 & 4.87 & 3.57 \\
Nitrate-supportable Ca $(\mathrm{mM})^{b}$ & 5.36 & 5.68 & 4.36 & 3.25 & 1.68 \\
Carbonate-supportable Ca $(\mathrm{mM})^{c}$ & -- & 2.15 & 2.03 & 1.74 & 1.76 \\
Ca-supporting surplus $(+)$ or deficit $(-)(\mathrm{mM})$ & -- & +1.86 & +1.02 & +0.12 & -0.13 \\
Mean conductivity $(\mu \mathrm{S} / \mathrm{cm})$ & --- & 2,082 & 1,699 & 1,038 & 1,167 \\
\hline
\end{tabular}

${ }^{a}$ As measured by ICP; mM values computed from annual mean parts per million data provided in Appendix A.

${ }^{b}$ Converted to $\mathrm{mM}$ from annual mean data for $\mathrm{N}$ provided in Appendix $\mathrm{A}$.

${ }^{c}$ Converted to $\mathrm{mM}$ from alkalinity data.

Table 3.13. Levels of calcium in relation to nitrate, alkalinity, and conductivity in BCK 12.4-12.36.

\begin{tabular}{lccccc}
\hline Condition & 1990 & 1991 & 1992 & 1993 & 1994 \\
\hline${\text { Calcium present }(\mathrm{mM})^{a}}^{a}$ & 4.30 & 4.32 & 3.83 & 4.00 & 3.68 \\
${\text { Nitrate-supportable Ca }(\mathrm{mM})^{b}}$ & 1.12 & 1.63 & 0.87 & 0.64 & 0.40 \\
${\text { Carbonate-supportable } \mathrm{Ca}(\mathrm{mM})^{c}}$ & 2.59 & 2.48 & 3.06 & 1.72 & 2.36 \\
Ca-supporting surplus $(+)$ or deficit $(-)(\mathrm{mM})$ & -0.59 & +0.21 & -0.10 & +1.64 & +0.92 \\
Mean conductivity $(\mu \mathrm{S} / \mathrm{cm})$ & 2,540 & 2,536 & 1,815 & 923 & 1,476 \\
\hline
\end{tabular}

${ }^{a}$ As measured by ICP; mM values computed from annual mean parts per million data provided in Appendix A.

${ }^{b}$ Converted to $\mathrm{mM}$ from annual mean data for $\mathrm{N}$ provided in Appendix $\mathrm{A}$

${ }^{\circ}$ Converted to $\mathrm{mM}$ from alkalinity data.

The mean levels of nitrate at BCK 11.83 and 12.36 have also declined substantially (64\% to 68\%) since 1990 . Carbonate plus bicarbonate ions (estimated from alkalinity titrations) available to support calcium have also declined through time (by about $9 \%$ at BCK 12.36 , and $18 \%$ at BCK 11.83). The changes in nitrate and carbonate plus bicarbonate at the two sites have resulted in a steady increase in relative importance of (carbonate + bicarbonate), over nitrate, as a calciumsupporting constituent (from $27.5 \%$ to
$51.1 \%$ of the total for nitrate plus carbonate at BCK 11.83, from 1991 to 1994; and from $69.8 \%$ to $85.5 \%$ of the total for nitrate plus carbonate at BCK 12.36 , from 1990 to 1994 ).

The quantities of nitrate and (carbonate + bicarbonate) anions at both sites generally have been sufficient to support the measured levels of calcium. In 1990 , a small calcium-supporting deficit $(-0.59 \mathrm{mM})$ was noted at BCK 12.36 ; in 1994 , a slight deficit $(-0.13 \mathrm{mM})$ in amount of nitrate and carbonate needed to 
support the measured levels of calcium was evident at BCK 11.83. These deficits are small enough so that they easily could be met by other anions (e.g., sulfate or chloride), for which data are not available. At BCK 11.83 , mean conductivity has declined by $42 \%$ from 1991 to 1994; at BCK 12.36, the conductivity decline during 1990-94 was 44\%. Collectively, the temporal changes in conductivity, nitrate, and calcium at the two sites in upper Bear Creek provide strong evidence for the idea that water quality there is improving: the water is now less saline, and there has been a progressive shift towards a bicarbonate-carbonate mediated ionic system, a condition more typical for streams in the southeastern United States.

\subsection{CONCLUSIONS AND RECOMMENDATIONS}

Previous studies revealed that water in upper Bear Creek (e.g., BCK 12.36) was toxic to Ceriodaphnia dubia and Daphnia magna, and showed that this toxicity was due at least in part to the presence of nickel (Kszos et al. 1992b), a metal that is much more toxic to daphnids than to fish. The presence of elevated concentrations of nickel in upper Bear Creek, at concentrations below EPA's water-quality criterion, could help explain the depauperate condition of the invertebrate community. Other constituents, too, are likely to contribute to toxicity in upper Bear Creek: a likely suspect is calcium, due to its high concentrations (occasionally over $500 \mathrm{mg} / \mathrm{L}$ ) and reported toxicity to Ceriodaphnia ( $2115 \mathrm{mg} / \mathrm{L}$ ). Calcium levels, and nitrate and (carbonate + bicarbonate) anions that can support calcium in dissolved phase, have declined in upper Bear Creek over the past several years. However, the water there is still toxic to Ceriodaphnia. Given the present rate of calcium decline, this cation should be below levels that are toxic to Ceriodaphnia at BCK 11.83 by the end of 1995 , and at or below toxic levels at BCK 12.36 by the end of 1998 . Continued monitoring of upstream conditions through use of ambient tests with Ceriodaphnia, with inspection of results to assess the $\mathrm{SR}_{15}$ location in the stream, will be used to document gradual improvement in biological quality of the water in upper Bear Creek.

\subsection{FUTURE STUDIES}

Water from six main-stem sites in Bear Creek (Table 3.1) will be tested for acute and chronic toxicity to Ceriodaphnia quarterly. Concurrently with these tests, Ceriodaphnia will be used to assess toxicity of water from three springs (SS-1, SS-4, and SS-5) and two tributaries (NT-1 and NT-2). In previous tests, water from SS-5 was not toxic (Tables 3.8, 3.9); this spring contributes a considerable amount of flow to Bear Creek and will be used as an internal control. In both previous test periods, Ceriodaphnia reproduction or survival was low in water from SS-1 and SS-4 (Tables 3.8 and 3.9). Water from NT-1 and NT-2 was toxic in one of the two test periods.

Dilution caused by rain events is a potentially significant modifier of ambient toxicity and could be monitored readily using Hydrosonde III instruments. These devices can be deployed in situ, and can be programmed to record data for $\mathrm{pH}$, water temperature, conductivity, and turbidity. They have been used to demonstrate strong diel fluctuations in $\mathrm{pH}$ in East Fork Poplar Creek (EFPC) and White Oak Creek, and to document episodic excursions in conductivity and temperature associated with a fish kill event in upper EFPC (K. Freye and A. J. Stewart, unpublished data). These devices will be deployed in Bear Creek at two sites (e.g., 
BCK 11.83 and 11.09). If a significant rainfall event occurs when the devices are deployed, temporal changes in conductivity will be used to estimate (1) the mean travel time for water between the two sites and (2) the length of time needed to restore chemical regimes similar to those present occurring before the event (i.e., return-time to base-flow conditions).

A semi-quantitative survey will be conducted to establish the distribution and abundance patterns of Elimia in Bear Creek and its tributaries. This survey will involve counting the numbers of snails present on substrates in three haphazardly selected sites in each tributary, and at sites in main-stem Bear Creek immediately upstream and downstream of each tributary. The information will be obtained in April or May 1995, near the onset of leaf-out of woody riparian vegetation. If conducted annually thereafter, such surveys could effectively document stream recovery, as evidenced by recolonization patterns and population densities of Elimia. 


\title{
4. BIOACCUMULATION STUDIES
}

\author{
G. R. Southworth and M. J. Peterson
}

\subsection{INTRODUCTION}

The original biological monitoring in Bear Creek, conducted in response to the Memorandum of Understanding agreed to in 1983, did not include bioaccumulation monitoring. As bioaccumulation monitoring in other aquatic systems on ORR expanded and began to show a pattern of mercury and polychlorinated biphenyl (PCB) contamiration in waters downstream from Bear Creek, the need for understanding the role of Bear Creek as a possible source for some of this contamination became evident.

Bioaccumulation monitoring was initiated in Bear Creek in 1987 as part of the Y-12 Biological Monitoring and Abatement Program for East Fork Poplar Creek (Hinzman 1993). Previous monitoring in Poplar Creek downstream from the mouth of EFPC had found little difference in mercury and $\mathrm{PCB}$ concentrations in fish from lower EFPC and Poplar Creek embayment, despite substantial dilution from the additional flow of mainstem Poplar Creek (Southworth 1990). Mercury and PCB monitoring in fish from lower Bear Creek was conducted in order to ascertain whether contamination in Bear Creek was the cause of this anomaly. Monitoring at that site was deemed important to understanding changes in $\mathrm{PCB}$ concentrations in fish in Poplar Creek and placing results of monitoring in upper EFPC in context; therefore the sampling was continued on a regular basis. In order to document changes associated with remediation of PCB sources in Bear Creek valley (oil retention ponds and burial ground seeps), PCB monitoring in caged clams was initiated in 1988 at

BCK 4.5 and expanded to include fish in 1990.

Forage fish (Central stoneroller, Campostoma anomalum) were sampled at three sites in Bear Creek (BCK 12.4, 9.4, and 3.3; Fig. 4.1) and a reference site (Hinds Creek, Anderson County, Tennessee) in June 1994 and analyzed for a suite of metals and hydrophobic chlorinated organics in support of an ecological risk analysis for Bear Creek.

\subsection{METHODS}

Rock bass (Ambloplites rupestris) was selected as the target species for bioaccumulation monitoring in Bear Creek. In lower Bear Creek, rock bass is abundant and is the numerically dominant sport/game species present. Redbreast sunfish, the most abundant sport/game species in nearby EFPC, is not abundant in lower Bear Creek, although it is found there. At BCK 4.5, habitat is more limited, and neither species is reliably abundant. Redbreast sunfish appeared to be more common, and it was selected in 1990, when collections started at this site; but thereafter, adequate numbers of rock bass were obtained there. Fish were collected by backpack electrofishing, twice yearly (generally). Eight fish were taken from BCK 0.6 for PCB and mercury analysis, and four fish taken for the same analyses at BCK 4.5. Central stonerollers (Campostoma anomalum) were collected at BCK 12.4, 9.4, and 3.3 in June 1994 to survey for metal and PCB contamination. Individual whole body analyses were carried out on eight fish at each site. 


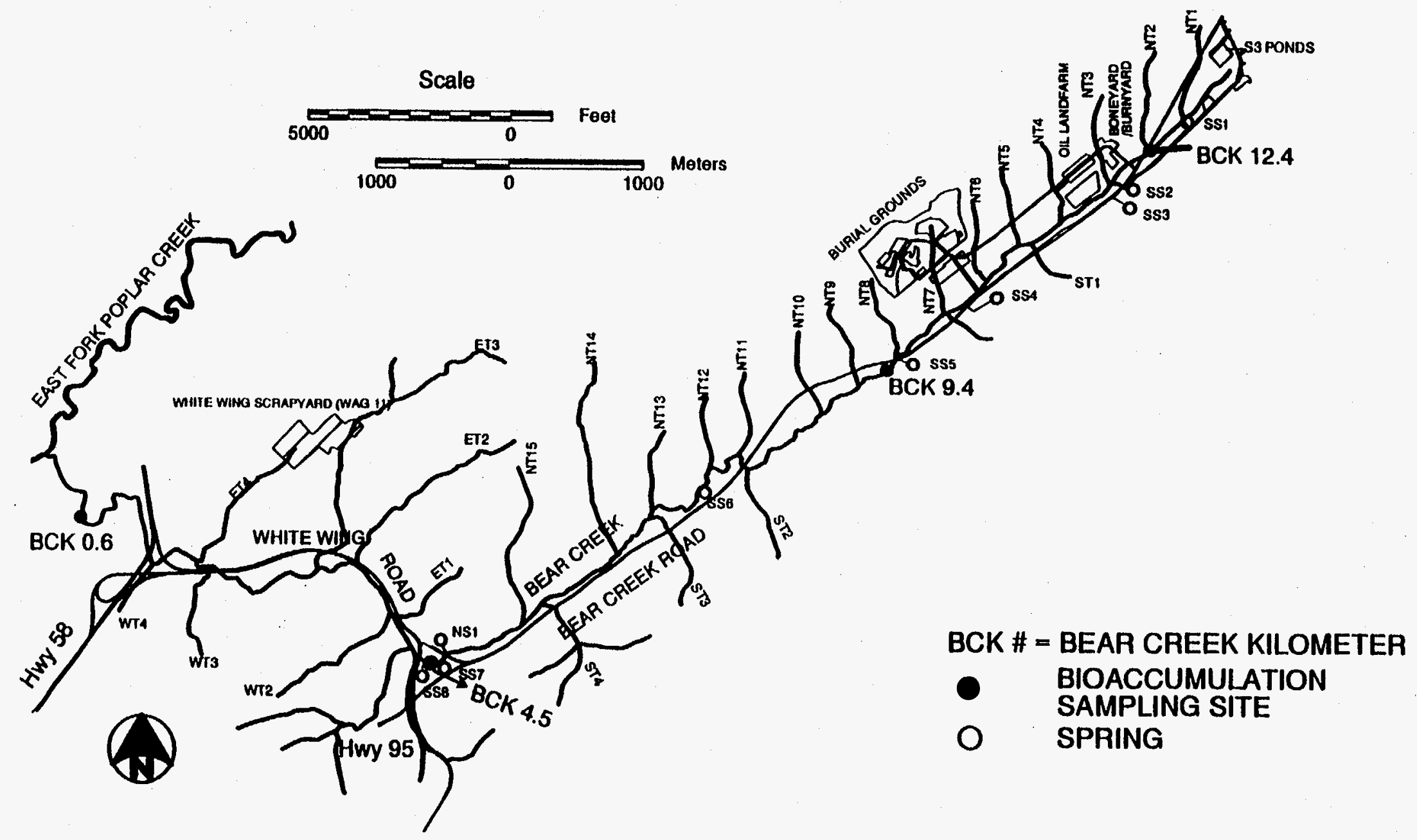

Fig. 4.1. Location of bioaccumulation sampling sites. WT $=$ west tributary, ET = east tributary, $\mathrm{ST}=$ south tributary, NT $=$ north tributary, SS $=$ south spring, NS $=$ north spring. 
Collections of sunfish were restricted whenever possible to fish of a size large enough to be taken by sport fisherman $(\geq 50 \mathrm{~g})$ in order to minimize effects of covariance between size and contaminant concentrations and to provide data directly applicable to assessing risks to people who might eat fish from these sources. Each fish was first tagged with a unique four digit tag wired to the lower jaw and then placed on ice in a labeled ice chest. Fish were held on ice overnight and processed the next day. Each fish was weighed and measured, then fileted, scaled, and rinsed in process tap water. Samples of sunfish for specific analyses were excised, wrapped in heavy duty aluminum foil, labeled, and frozen in a standard freezer at $-15^{\circ} \mathrm{C}$. Samples of tissue $(5-10 \mathrm{~g}$ for PCBs, 2-5 $\mathrm{g}$ for $\mathrm{Hg}$ ) were submitted to ORNL Analytical Services Organization (ASO) for analysis. Any remaining tissue from filets was wrapped in foil, labeled, and placed in the freezer for short-term archival storage. Whole stonerollers were weighed, measured, wrapped in aluminum foil, labelled, and frozen prior to submission for analysis.

Asiatic clams (Corbicula fluminea), an effective monitor for organic contaminants in small streams (Peterson et al. 1994), were placed in Bear Creek to monitor for PCBs. Clams were obtained from different reference sites in different years, depending on abundance. Little Sewee Creek (Meigs County, Tennessee); Beaver Creek and Bull Run (Knox County, Tennessee); and Paint Rock Creek (McMinn County, Tennessee) served as reference sites (Fig. 4.2). After the clams were held for $24 \mathrm{~h}$ in clean flowing water, they were put into polypropylene cages and placed at BCK 4.5. One set of clams collected from the reference site was frozen immediately for analysis as a control. Each cage held approximately
50 clams, each of which contained 0.5-2 g (wet wt) of soft tissue. The clams were suspended in the stream for four weeks, at which time they were removed, returned to the laboratory, and stored at $-15^{\circ} \mathrm{C}$ in a locked freezer prior to processing. The shells were removed from frozen clams, and the frozen soft tissue was placed in a 20 -ml glass vial. Duplicate composite samples weighing approximately 5-10 g were taken for PCB analyses. The samples were later delivered to the ORNL ASO for analysis.

PCB determinations in fish and clams were conducted by packed column gas chromatography/electron capture detection (GC/ECD) using a method based on EPA procedure PPB 12/83 (EPA 1984), which involves homogenizing the sample in anhydrous sodium sulfate, extraction with methylene chloride, cleanup using column chromatography, and GC/ECD. Fish were analyzed for total mercury by cold vapor atomic absorption spectrophotometry following digestion in $\mathrm{HNO}_{3} / \mathrm{H}_{2} \mathrm{SO}_{4}$ (EPA 1991, procedure 245.6). Individual whole fish were analyzed for antimony, arsenic, beryllium, cadmium, chromium, copper, lead, lithium, nickel, selenium, silver, thallium, uranium, and zinc by inductively coupled plasma/mass spectrometry (EPA 1991, method 200.8).

Quality assurance was maintained by a combination of blind duplicate analyses, analysis of biological reference standards and uncontaminated fish, and determination of recoveries of analyte spikes to uncontaminated fish. Statistical evaluations of data were conducted using SAS procedures and software (SAS 1985a, 1985b) for ANOVA, ANCOVA, linear regression, and the calculation of summary statistics. All comparisons were conducted using $p=0.05$. SPSS software (Norusis 1993) was used for $t$-tests and Levenes text. The level of significance selected for all statistical procedures was 0.05 . 


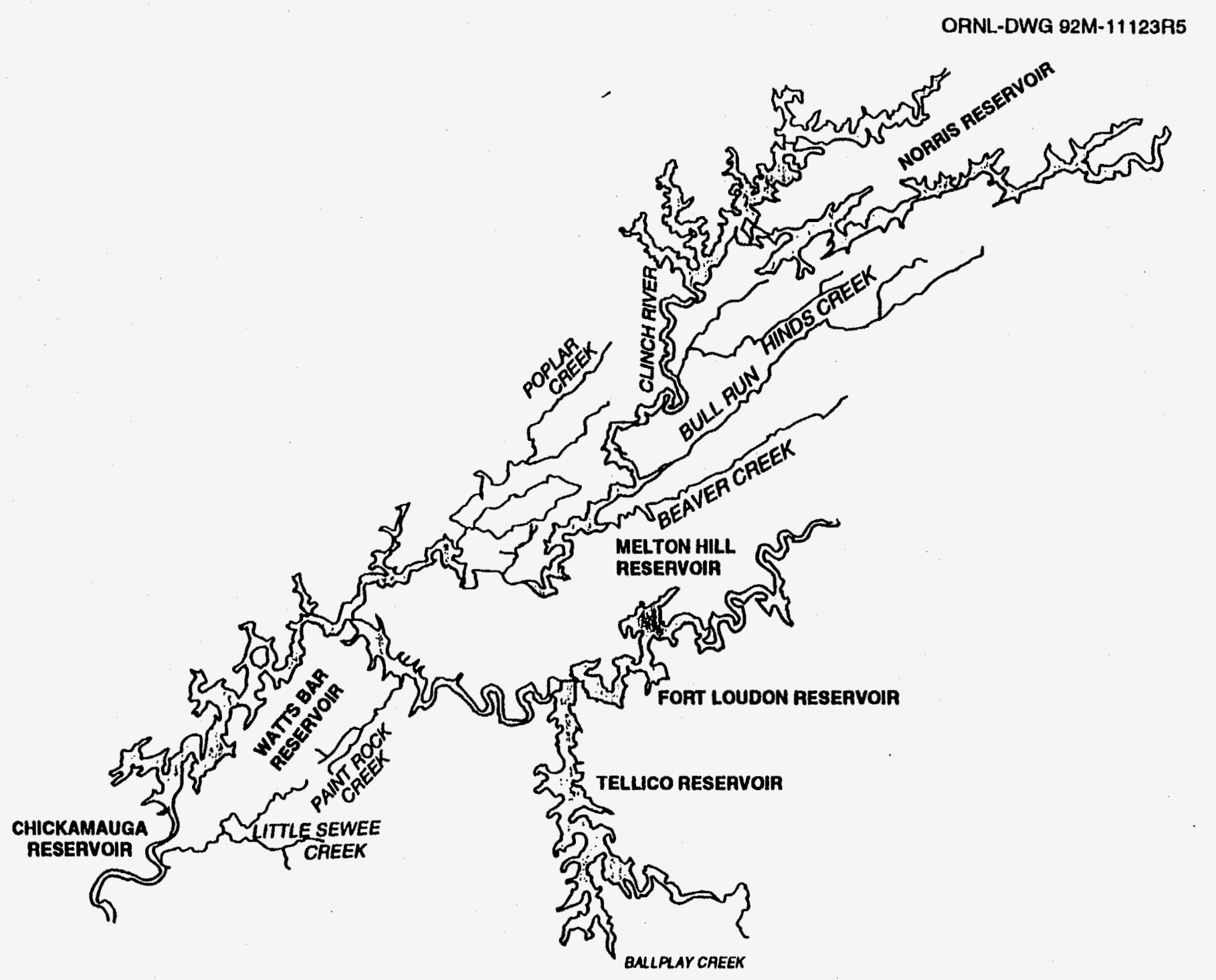

Fig. 4.2. Location of reference streams for the bioaccumulation task. 


\subsection{RESULTS AND DISCUSSION}

\subsubsection{Mercury}

Previous studies had detected abovebackground concentrations of mercury in fish from lower Bear Creek. In 1982, mercury concentrations ranged from 0.2 to $0.5 \mu \mathrm{g} / \mathrm{g}$ in rock bass (Van Winkle et al. 1984). This finding was corroborated in 1985 in follow-up monitoring by the Tennessee Valley Authority (TVA) as part of the Oak Ridge Task Force (TVA 1985).

Results of monitoring conducted in lower Bear Creek from 1988 through 1993 indicate that mean mercury concentrations in rock bass continue to be elevated relative to reference sites (Southworth et al. 1994b) in Bear Creek (Table 4.1, and A.7) but are well below the $1 \mu \mathrm{g} / \mathrm{g}$ FDA limit (FDA 1984a). Mean mercury concentrations in fish from BCK 4.5 were similar to, but more variable than, concentrations in fish from BCK 0.6. However, mean mercury concentrations in rock bass at $\mathrm{BCK} 0.6$ have increased at a steady rate between 1988 and 1993

(Fig. 4.3), nearly doubling over that period. A pronounced periodicity is evident in the data in Fig. 4.3, with mean mercury concentrations in fish collected in the spring (generally late May) being lower than those in fish collected the preceding or following fall (generally November).

Mercury concentrations in fish from the same environment are typically higher in larger specimens than in smaller ones. This covariance is addressed in the EFPC BMAP studies by restricting the size of redbreast sunfish collected to fish $250 \mathrm{~g}$ in size. Because this species seldom exceeds $150 \mathrm{~g}$, the mean size of fish in collections from different sites and dates is generally similar, and effects of $\mathrm{Hg} /$ size covariance are negligible. Rock bass, however, attain larger sizes and exhibit a wider range in size within collections than sunfish.
Therefore, it was necessary to adjust mercury concentrations in fish from different collection dates by using analysis of covariance. Results of this statistical adjustment made little difference in the pattern of mercury in fish vs time (Fig. 4.4). The seasonal periodicity remains clearly evident, and the steady increase in mercury concentration in fish is obvious. Linear regression of adjusted mean mercury concentrations vs time for spring and fall sampling periods yield separate regression lines with parallel slopes (Fig. 4.4).

Increasing concentrations of mercury in predatory fish from Bear Creek present a concern. Remedial actions at discontinued waste disposal sites in Bear Creek valley have produced substantial ecological recovery and improvement in chemical water quality. Although it is possible that earthmoving and construction activities associated with remedial measures may have disturbed mercury contaminated sites and mobilized additional mercury, it is also possible that these increases are a consequence of improved water quality and/or ecological recovery. In nearby Rogers Quarry, elimination of discharges of selenium-rich fly ash to the quarry was followed by steadily increasing mercury concentrations in largemouth bass (Southworth et al. 1994a). This was attributed to increased bioavailability of mercury in the absence of abnormally high concentrations of waterborne selenium. Decreases in inorganic nutrients entering Bear Creek [i.e., approximately 50\% decrease in $\mathrm{NO}_{3}$ since 1986 (Sect. 2.5 and App. A)] may have altered rates of transformation of inorganic mercury to methylmercury within the stream periphyton community. Improvements in ecological conditions in the upper reaches of Bear Creek have resulted in the abundance of fish and invertebrates in headwater reaches where aquatic life was uncommon in 1986 . Such changes may 
Table 4.1. Mean concentrations ( $\pm 1 \mathrm{SE}$ ) of mercury and PCBs in filets of rock bass (Ambloplites rupestris) and redbreast sunfish (Lepomis auritus) from Bear Creek ( $n=8$ at BCK $0.6, n=4$ at BCK 4.5), and mean concentrations of PCBs in duplicate composite samples of caged clams (Corbicula fluminea) exposed for 4 weeks at BCK 4.5

\begin{tabular}{|c|c|c|c|c|}
\hline Site & Species & Date & $\begin{array}{c}\mathrm{Hg}^{a} \\
(\mu \mathrm{g} / \mathrm{g})\end{array}$ & $\begin{array}{l}\mathrm{PCB}^{b} \\
(\mu \mathrm{g} / \mathrm{g})\end{array}$ \\
\hline BCK 0.2 & Rock bass & Dec. 1987 & $0.32 \pm 0.07$ & $0.28 \pm 0.04$ \\
\hline BCK 0.6 & Rock bass & Dec. 1988 & $0.41 \pm 0.06$ & $0.19 \pm 0.05$ \\
\hline BCK 0.6 & Rock bass & May 1989 & $0.34 \pm 0.03$ & $0.14 \pm 0.02$ \\
\hline BCK 0.6 & Rock bass & Dec. 1989 & $0.52 \pm 0.04$ & $0.52 \pm 0.19$ \\
\hline BCK 0.6 & Rock bass & May 1990 & $0.39 \pm 0.04$ & $0.26 \pm 0.07$ \\
\hline BCK 0.6 & Rock bass & Dec. 1990 & $0.53 \pm 0.04$ & $0.37 \pm 0.12$ \\
\hline BCK 0.6 & Rock bass & May 1991 & $0.43 \pm 0.06$ & $0.11 \cdot 0.06$ \\
\hline BCK 0.6 & Rock bass & Dec. 1991 & $0.57 \pm 0.05$ & $0.08 \pm 0.01$ \\
\hline BCK 0.6 & Rock bass & May 1992 & $0.45 \pm 0.05$ & $0.06 \pm 0.01$ \\
\hline BCK 0.6 & Rock bass & Dec. 1992 & $0.61 \pm 0.11$ & $0.14 \pm 0.04$ \\
\hline BCK 0.6 & Rock bass & May 1993 & $0.57 \pm 0.07$ & $0.08 \pm 0.03$ \\
\hline BCK 0.6 & Rock bass & Dec. 1993 & $0.65 \pm 0.06$ & $0.18 \pm 0.05$ \\
\hline BCK 4.5 & Redbreast & May 1990 & $0.27 \pm 0.03$ & $0.97 \pm 0.23$ \\
\hline BCK 4.5 & Rock bass & Dec. 1990 & $0.52 \pm 0.08$ & $1.63 \pm 0.48$ \\
\hline BCK 4.5 & Redbreast & May 1991 & $0.39 \pm 0.07$ & $0.51 \pm 0.18$ \\
\hline BCK 4.5 & Rock bass & Dec. 1991 & $0.77 \pm 0.13$ & $0.09 \pm 0.02$ \\
\hline BCK 4.5 & Rock bass & May 1992 & $0.52 \pm 0.07$ & $0.16 \pm 0.02$ \\
\hline BCK 4.5 & Rock bass & Dec. 1992 & $0.63 \pm 0.19$ & $1.03 \pm 0.51$ \\
\hline BCK 4.5 & Rock bass & May 1993 & $0.18 \pm 0.03$ & $0.16 \pm 0.05$ \\
\hline BCK 4.5 & Rock bass & Dec. 1993 & $0.79 \pm 0.07$ & $1.78 \pm 0.84$ \\
\hline BCK 4.5 & Clams & Apr. 1988 & NS & $1.01 \pm 0.58$ \\
\hline BCK 4.5 & Clams & Apr. 1989 & NS & $0.92 \pm 0.10$ \\
\hline BCK 4.5 & Clams & Apr. 1990 & NS & $0.87 \pm 0.20$ \\
\hline BCK 4.5 & Clams & May 1991 & NS & $1.27 \pm 0.12$ \\
\hline BCK 4.5 & Clams & May 1992 & NS & $0.23 \pm 0.01$ \\
\hline BCK 4.5 & Clams & May 1993 & NS & $0.21 \pm 0.09$ \\
\hline
\end{tabular}

${ }^{a}$ Background (Hinds Creek, Tennessee) mercury concentration in sunfish $-0.08 \pm 0.01 \mu \mathrm{g} / \mathrm{g}$. Table 4.1

${ }^{b}$ Typical PCB concentration in uncontaminated fish and clams $-<0.05 \mu \mathrm{g} / \mathrm{g}$.

Note: NS = not sampried. 


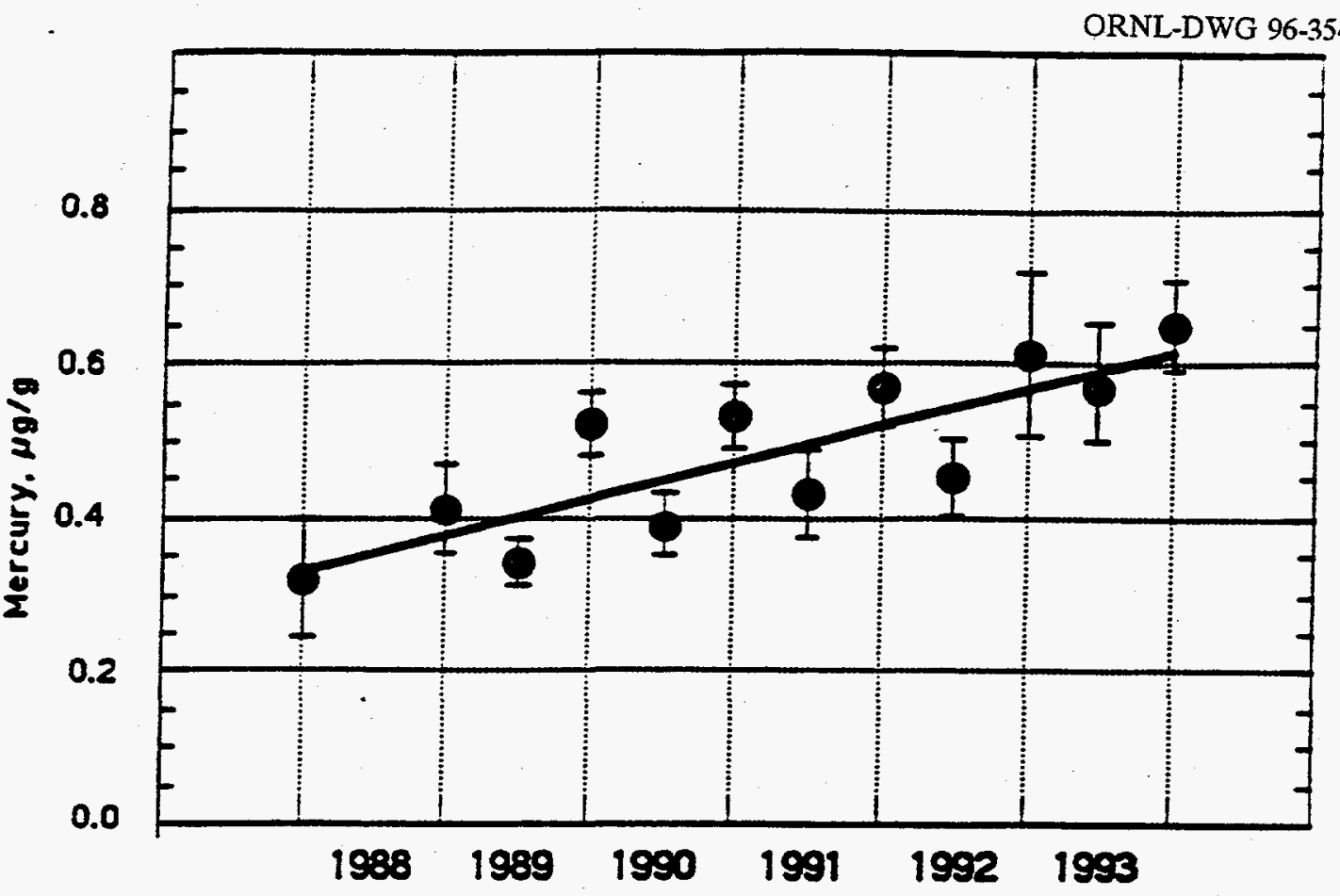

YEAR

Fig. 4.3. Mean concentration of mercury ( $\left.{ }_{ \pm} \mathrm{SE}, n=8\right)$ in rock bass at $\mathrm{BCK} 0.6$ vs time. Data are not adjusted for covariance of $\mathrm{Hg}$ with fish weight. The regression expression is $\mathrm{Hg}=0.33+0.0476$ (years since January 1988), $\mathrm{r}^{2}=0.69$.

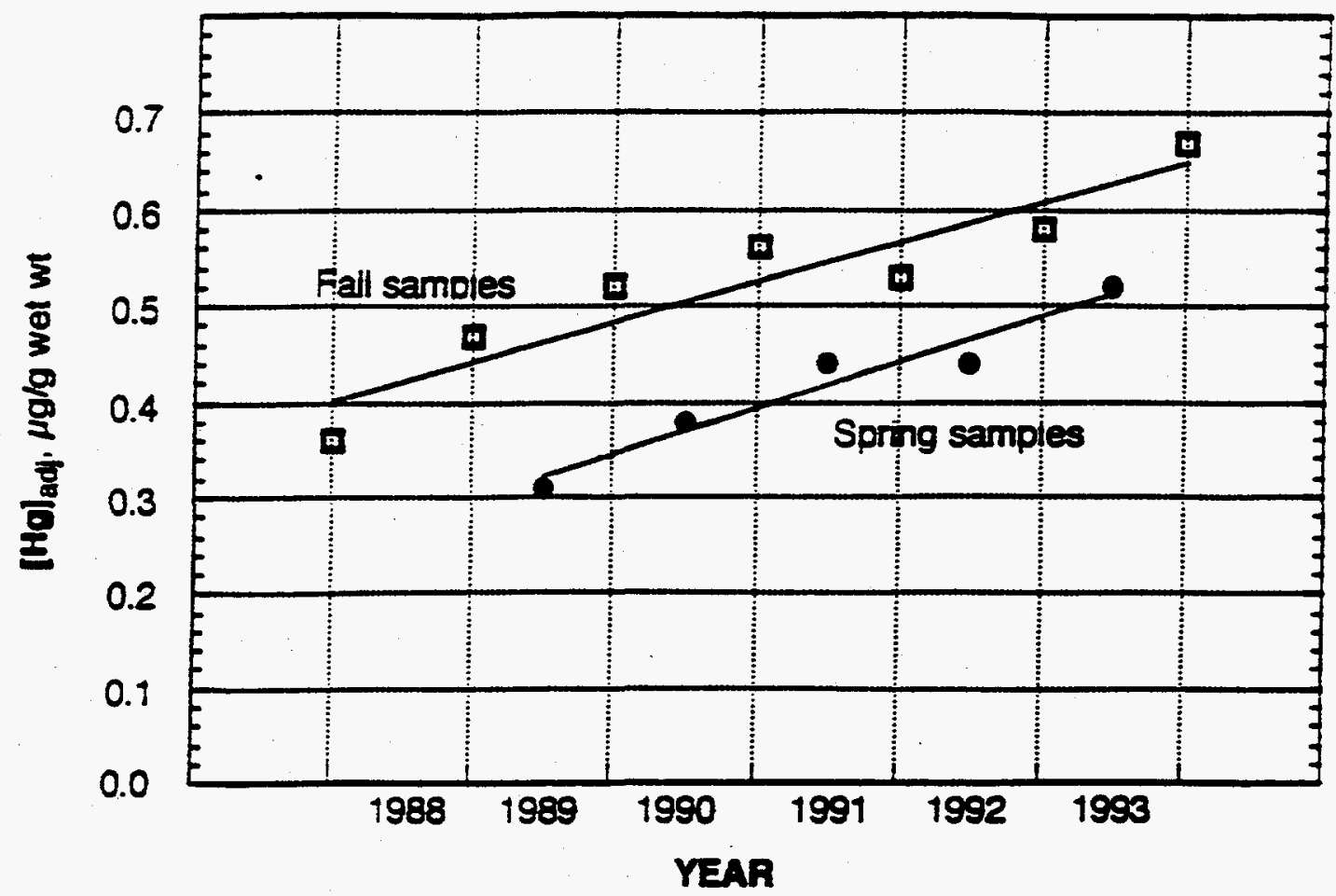

Fig. 4.4. Mean mercury concentrations in rock bass (Ambloplites rupestris) from lower Bear Creek (kilometer 0.6) 1988-93. Mercury concentrations were adjusted for covariance with fish weight using analysis of covariance. The solid line is the least squares best fit for the linear regression of $[\mathrm{Hg}]_{\mathrm{adj}}$ vs time for the spring and fall samples separately. 
have resulted in Bear Creek becoming more efficient at transferring

methylmercury produced within the system to aquatic life and retaining it. Thus, even with no additional mercury inputs to the system, it is possible that more methylmercury is being produced and/or retained as ecological conditions improve, causing mercury concentrations in biota to rise.

\subsubsection{PCBs}

PCB contamination (mean, $0.65 \mu \mathrm{g} / \mathrm{g}$ ) was evident in rock bass from lower Bear Creek in a 1982 sampling conducted by W. Van Winkle, ORNL Environmental Sciences Division (Southworth et al. 1992), but convincing evidence of contamination was not found by the Oak Ridge Task Force study in 1984 (TVA 1985).

Monitoring carried out since 1984 has found evidence of PCB contamination on all sampling dates, but mean concentrations have always been below the FDA tolerance limit of $2 \mu \mathrm{g} / \mathrm{g}$ (FDA 1984b). Results of PCB monitoring in rock bass conducted by Environmental Sciences Division (ESD) BMAP are presented in Table 4.1 and Fig. 4.5. Mean concentrations in lower Bear Creek (BCK 0.6) have typically remained in the 0.1-0.3 range from 1987 to 1993 , except for the period from December 1989 through December 1990, when average concentrations of $0.3-0.5$ $\mu \mathrm{g} / \mathrm{g}$ were typical (Appendix A, Table A.7). It is likely that the increase observed in 1990 was related to the disturbance of PCB contaminated areas upstream during the remediation of the oil retention ponds and burial ground seeps that were the primary sources of PCBs to Bear Creek. Mean PCB concentrations in rock bass at BCK 0.6 have remained below $0.2 \mu \mathrm{g} / \mathrm{g}$ since the end of 1990 (Fig. 4.5). PCB concentrations in sunfish from lower EFPC have averaged $0.1-0.2 \mu \mathrm{g} / \mathrm{g}$ from 1991 to 1993-about the concentration found in Bear Creek rock bass (Kornegay et al. 1993).

PCB concentrations in fish from middle reaches of Bear Creek (BCK 4.5) were, in most cases, much higher than at BCK 0.6 but also exhibited much greater variability between sampling periods. Availability of suitable fish at BCK 4.5 was inconsistent; therefore, redbreast sunfish were taken on some occasions and rock bass on others. The inconsistent presence of these species at this site, coupled with the large temporal swings in PCB concentrations, suggests that some fish in these collections may not be long-term residents at the sites.

Mean PCB concentrations in fish at BCK 4.5 approached or exceeded $1 \mu \mathrm{g} / \mathrm{g}$ on four of eight sampling dates (Table 4.1, Fig. 4.5). High concentrations in 1990 may have been related to remedial actions, as noted previously. These were followed by substantial improvement in 1991 and early 1992. However, fish collected in December 1992 and December 1993 again contained relatively high $\mathrm{PCB}$ concentrations. PCB concentrations in sunfish in EFPC follow a similar pattern of being high at headwater sites nearest presumed sources, and decreasing rapidly within a few kilometers downstream (Southworth 1990). In EFPC, PCB concentrations in fish decrease relatively little with further distance downstream. The high concentrations in fish at $\mathrm{BCK} 4.5$ relative to $\mathrm{BCK} 0.6$ suggest that the present source of contamination to fish is close to BCK 4.5 , if a pattern such as that observed in EFPC occurs in Bear Creek.

Caged clams have been used to monitor PCBs at BCK 4.5 since 1988. These are placed in the stream for 4 weeks; and thus, unlike fish, the duration and location of exposure is explicitly known. Results of this monitoring are presented in Table 4.1, and compared with fish results in Fig. 4.6. The clam data seem 

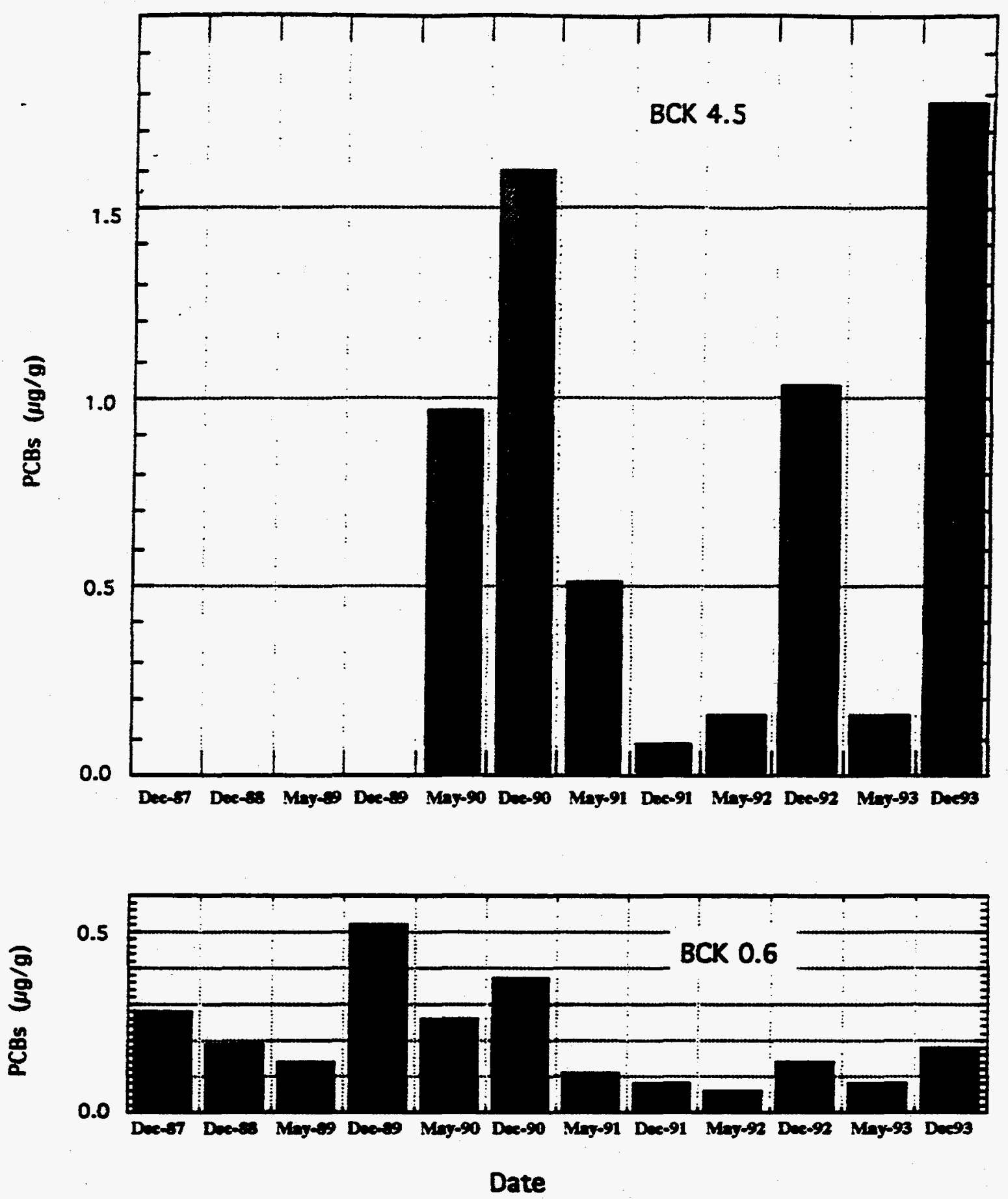

Fig. 4.5. Mean concentrations of polychlorinated biphenyls (PCBs) in rock bass from sites in Bear Creek, 1987-93. BCK = Bear Creek kilometer. 


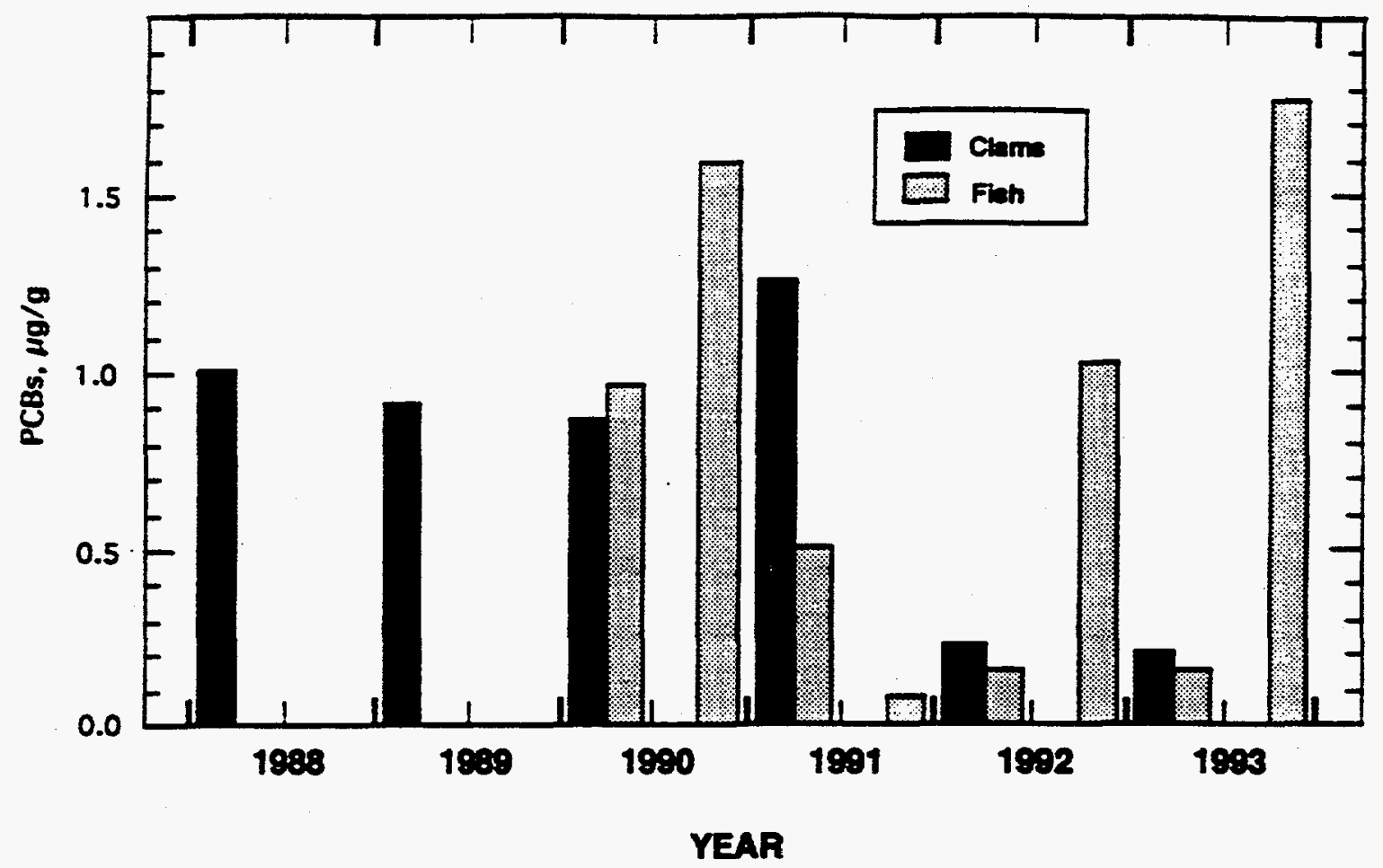

Fig. 4.6. Mean concentrations of polychlorinated biphenyls (PCBs) in caged clams and resident fish from Bear Creek kilometer 4.5.

to mirror fish results relatively well, being low when fish PCB concentrations are low and high when fish levels are high.

Unfortunately, the high PCB

concentrations observed in fish in 1992 and 1993 occurred in samples collected in December, while clam exposures were in May/June. Since clam exposures represent only a 4-week period, while fish concentrations probably represent an average of at least 4 to 6 months exposure, the clam data provide little insight for interpreting PCB concentrations in fish collected in fall/winter.

Evaluated independently, the clam data suggest that remedial actions completed in early 1990 have effectively reduced PCB contamination in Bear Creek surface water. The recent fish data at BCK 4.5 , however, indicate a highly seasonal pattern. The reach immediately upstream from BCK 4.5 consists of a long pool filled with fine sediment trapped behind the monitoring weir dam. Undoubtedly, this sediment contains PCB contamination. If remediation of upstream sources has successfully reduced inputs of PCBs to Bear Creek, PCB contaminated sediments behind the weir dam are now periodically being covered with "clean" sediment, which would serve to reduce mobilization of PCBs from the contaminated sediment to the water column. Because the weir dam pool is probably filled to near capacity with sediment, periodic high flows may strip away uncontaminated sediment and erode and expose PCB contaminated material. This process of successive covering/ uncovering could act to cause periodic swings in PCB exposure to organisms in a localized reach of stream near the weir dam pool. Such variations would be less likely further downstream (BCK 0.6), 
where sediment retention is low and additional dilution with uncontaminated water and sediment occurs.

\subsubsection{Contaminants in Forage Fish (Stonerollers)}

Although concentrations of most metals and pesticides in forage fish collected from Bear Creek in June 1994 were similar to levels found in reference site fish or below detection limits, cadmium, lithium, nickel, uranium, mercury, and PCBs were found to exceed reference site concentrations by a substantial margin (Table 4.2). Mercury, nickel, and cadmium were found to be highest at the site nearest the closed S-3 Pond site (Figs. 4.7, 4.8). These contaminants had been previously identified as associated with the S-3 Pond groundwater plume (Southworth et al. 1992) that infiltrates the upper reaches of Bear Creek. Lithium, uranium, and PCBs exhibited a different pattern, with the highest mean concentrations occurring at BCK 9.4 (Figs. 4.8, 4.9). Such a pattern was expected for PCBs, because sources were known to be located in the burial grounds upstream from BCK 9.4 rather than at the S-3 Pond site. High uranium and lithium concentrations in fish from BCK 9.4 indicate that there are additional sources of these elements to Bear Creek downstream from the S-3 plume. The striking difference in mean PCB concentration between stonerollers from BCK 12.4 and BCK 9.4 is evidence that populations of this species have relatively restricted home ranges in Bear Creek, and contaminant concentrations in whole stonerollers can be assumed to represent exposure conditions at the site of capture. Mean concentrations of several other elements significantly $(p<0.05)$ exceeded reference site means at some sites

(Table 4.2), but differences were small and no consistent site to site pattern was observed.

Average contaminant concentrations in stonerollers from some sites in Bear Creek exceeded conservatively derived toxicological benchmarks used for evaluating ecological risk to piscivorous birds and mammals (Opresko et al. 1994). Cadmium in fish at BCK 12.4 exceeded the toxicological benchmark for mink, as did PCBs in fish at BCK 9.4. Mean concentrations of selenium and arsenic exceeded or approached the toxicological benchmark for mink at all sites, including the Hinds Creek reference site. Zinc exceeded the benchmark concentration for kingfisher at all sites, including Hinds Creek. Mercury concentrations were low in stonerollers at all sites, because it eats primarily plant material which does not concentrate methylmercury to the extent animal tissue does. Mercury concentrations in stonerollers at BCK 12.4 , which were typical of levels found in predatory or omnivorous fish from uncontaminated streams in East Tennessee, nevertheless exceeded the toxicological benchmark for mink. Mercury concentrations in stonerollers exceeded the benchmark for kingfishers and great blue herons at all sites in Bear Creek. It is likely that the derived benchmarks are overly conservative in many of these cases, since the benchmarks approach or exceed concentrations that are typical of those species' food in uncontaminated environments.

Chemical monitoring for NPDES compliance at BCK 11.97 and BCK 12.4 revealed cadmium and uranium to be present at above background concentrations, but did not clearly identify nickel, lithium, mercury, or PCBs as being present at elevated concentrations. This was due in part to possible contaminant sources being downstream from the NPDES monitoring sites, and in part to 
Table 4.2. Mean ( \pm SE) concentrations ( $\mu \mathrm{g} / \mathrm{g}$ wet $w \mathrm{w}$ ) of metals and polychlorinated biphenyls (PCBs) in stonerollers (Campostoma anomahum) from Bear Creek, June 1994

\begin{tabular}{|c|c|c|c|c|}
\hline \multirow[t]{2}{*}{ Analyte } & \multicolumn{4}{|c|}{ Site } \\
\hline & BCK 12.4 & BCK 9.4 & BCK 3.3 & Hinds $\mathrm{Cr}$ \\
\hline Antimony & $0.004 \pm 0.002$ & $0.003 \pm 0.001$ & $0.003 \pm 0.001$ & $0.003 \pm 0.001$ \\
\hline Arsenic & $0.25 \pm 0.047$ & $0.43 \pm 0.054$ & $0.31 \pm 0.033$ & $0.22 \pm 0.016$ \\
\hline Beryllium & $0.016 \pm 0.007$ & $0.020 \pm 0.004$ & $0.011 \pm 0.003$ & $0.007 \pm 0.002$ \\
\hline Cadmium & $1.73 \pm 0.19^{* *}$ & $0.48 \pm 0.060^{* *}$ & $0.19 \pm 0.026^{* *}$ & $0.023 \pm 0.002$ \\
\hline Chromium & $0.70 \pm 0.093$ & $0.98 \pm 0.082$ & $0.79 \bullet 0.072$ & $0.72 \pm 0.082$ \\
\hline Copper & $0.83 \pm 0.060$ & $1.03 \pm 0.096^{*}$ & $1.00 \pm 0.039$ & $0.80 \pm 0.040$ \\
\hline Lead & $0.44 \pm 0.12$ & $0.53 \pm 0.091^{*}$ & $0.23 \pm 0.057$ & $0.25 \pm 0.045$ \\
\hline Lithium & $0.24 \pm 0.081$ & $0.76 \pm 0.144^{*}$ & $0.34 \pm 0.079$ & $0.18 \pm 0.047$ \\
\hline Mercury & $0.120 \pm 0.0099^{* *}$ & $0.079 \pm 0.0058^{\prime *}$ & $0.060 \pm 0.0059^{* *}$ & $0.013 \pm 0.0015$ \\
\hline Nickel & $2.45 \pm 0.57^{* *}$ & $0.85 \pm 0.11$ & $0.57 \pm 0.075$ & $0.61 \pm 0.042$ \\
\hline Selenium & $0.44 \pm 0.031$ & $0.61 \pm 0.080$ & $0.56 \pm 0.044$ & $0.42 \pm 0.009$ \\
\hline Silver & $0.015 \pm 0.002$ & $0.013 \pm 0.002$ & $0.025 \pm 0.003^{*}$ & $0.013 \pm 0.001$ \\
\hline Thallium & $0.008 \pm 0.001$ & $0.012 \pm 0.003$ & $0.006 \pm 0.001$ & $0.006 \pm 0.001$ \\
\hline Uranium & $0.73 \pm 0.108^{* *}$ & $0.98 \pm 0.092^{* *}$ & $0.42 \pm 0.041^{* *}$ & $0.010 \pm 0.003$ \\
\hline Zinc & $40.5 \pm 1.3$ & $48.3 \pm 2.8$ & $57.9 \pm 4.2^{*}$ & $42.1 \pm 1.7$ \\
\hline PCBs & $0.28 \pm 0.08^{* *}$ & $2.86 \pm 0.57^{* *}$ & $0.98 \pm 0.17^{* *}$ & $<0.06$ \\
\hline
\end{tabular}

Note: Asterisk indicates significant difference from reference site mean (two-tailed test, $p<0.05$ ). Dunnett's test was used when variances were homogeneous $\left({ }^{*}\right), t$-test with assumption of unequal variances was used for other cases $\left({ }^{* *}\right)$. BCK $=$ Bear Creek kilometer. 
ORNL-DWG 96-3546


Fig. 4.7. Mean concentrations of mercury and nickel in whole stonerollers from Bear Creek and Hinds Creek $\mathrm{BCK}=$ Bear Creek kilometer. 
ORNL-DWG $96-3547$
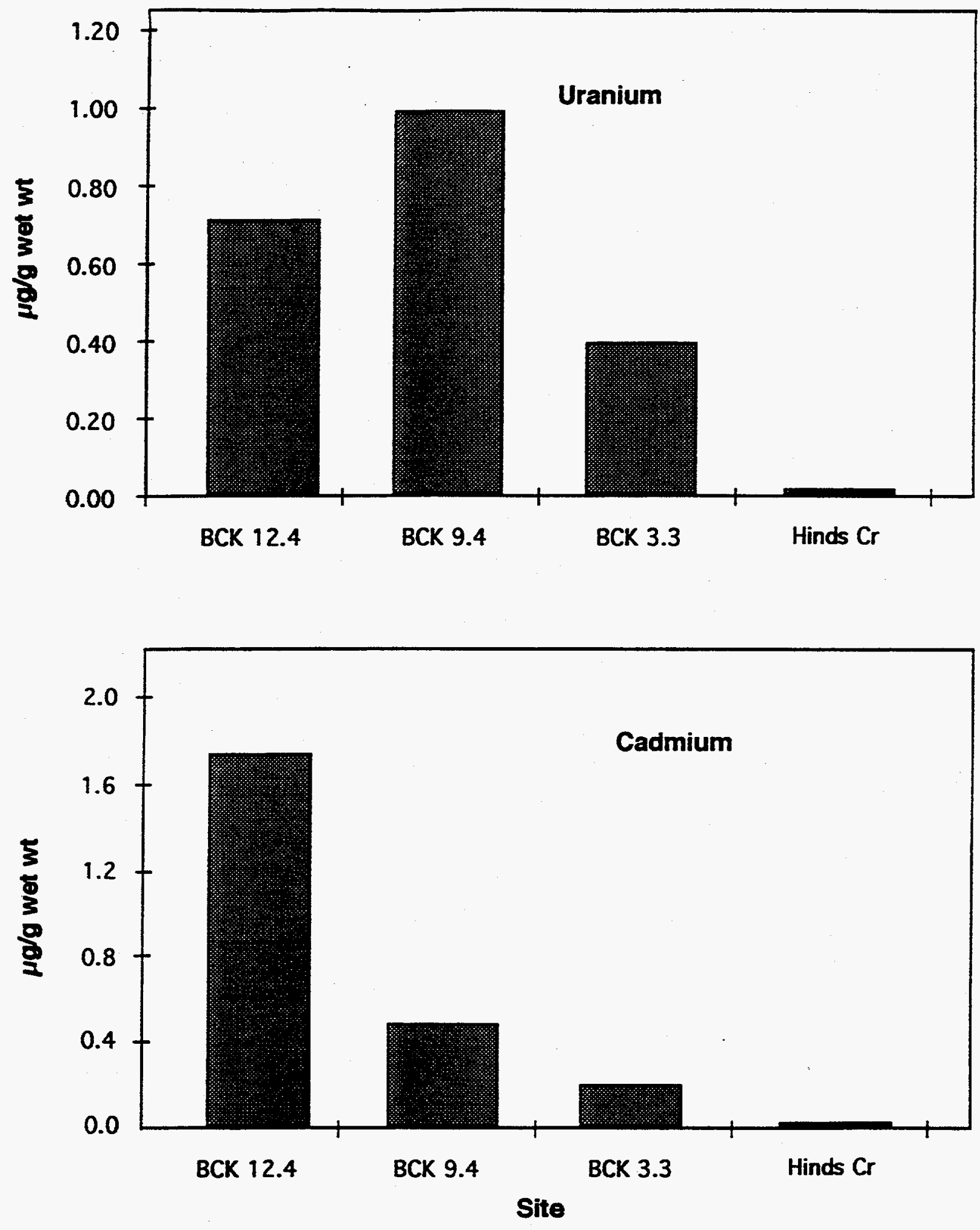

Fig. 4.8. Mean concentrations of uranium and cadmium in whole stonerollers from Bear Creek and Hinds Creek $\mathrm{BCK}=$ Bear Creek kilometer. 

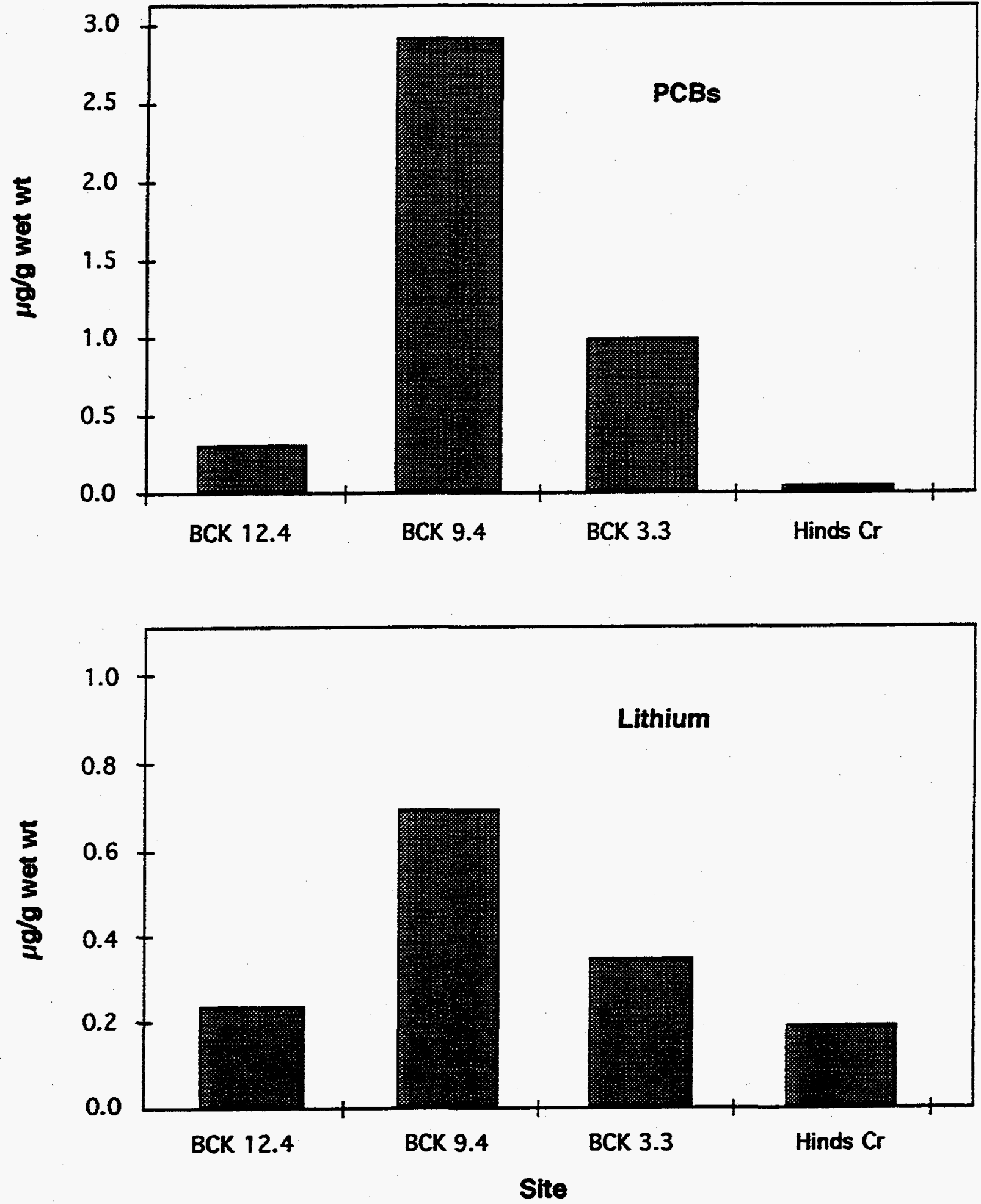

Fig. 4.9. Mean concentrations of polychlorinated biphenyls (PCBs) and lithium in whole stonerollers from Bear Creek and Hinds Creek $\mathrm{BCK}=$ Bear Creek kilometer. 
the contaminants not being present in water at high enough concentrations to detect.

\subsection{CONCLUSIONS}

Mercury contamination in fish in lower Bear Creek is steadily increasing, with no apparent source or cause. NPDES monitoring data at BCK 11.95 does not consistently detect mercury contamination (Kornegay et al. 1993). Mercury concentrations in stoneroller minnows indicate that the source of mercury contamination to stream biota is located in the vicinity of the S-3 groundwater plume.

Cadmium, uranium, lithium, and nickel occur at elevated concentrations in herbivorous forage fish in Bear Creek. Cadmium and nickel have been associated with the S-3 plume in previous studies (Southworth et al. 1992, Kszos et al. 1992b), and uranium and lithium have been associated with several disposal sites in upper Bear Creek. Additional high sensitivity measurements of aqueous phase mercury concentrations, coupled with measurements of mercury concentrations in fine sediments, are needed to help determine the source of mercury to Bear Creek fish and the explanation for its recent increase.

PCB contamination in fish in Bear Creek appears to have been reduced by remedial actions targeted at eliminating inputs to the creek from burial ground seeps and oil retention ponds. However, PCB contamination in stoneroller minnows indicates that the vicinity of the remediated disposal sites remains a source area to aquatic life. PCB contaminated soils remain in the creek floodplain, and accumulations of PCB contaminated sediments no doubt still occur at localized sites within the creek. Periodic high concentrations of PCBs in fish at BCK 4.5 may be related to seasonal or weather related variation in sediment transport and erosion.

\subsection{FUTURE STUDIES}

The present schedule of monitoring $\mathrm{PCBs}$ and mercury in fish and clams from Bear Creek will be maintained, with some proposed modification. PCB monitoring in rock bass at $\mathrm{BCK} 4.5$ will be discontinued, and replaced with $\mathrm{PCB}$ monitoring in stonerollers at BCK 9.4 and BCK 3.3. Concentrations of uranium, nickel, lithium, and cadmium will be monitored annually in stonerollers from BCK 12.4 and BCK 9.4. A proposal to study the relationships between forms of aqueous mercury (methylmercury, ionic, and elemental mercury) and mercury concentrations in fish at DOE sites in Tennessee and Kentucky will include Bear Creek as a sampling site. 


\title{
5. INSTREAM ECOLOGICAL MONITORING
}

\author{
G. F. Cada, E. M. Schilling, J. G. Smith, and M. R. Smith
}

\subsection{FISH COMMUNITY ASSESSMENT (E. M. Schilling)}

\subsubsection{Introduction}

Fish population and community studies can be used to assess the ecological effects of changes in water quality and habitat. These studies offer several advantages over other indicators of environmental quality (see Karr et al. 1986; Karr 1987, 1991) and are relevant to assessment of the biotic integrity of streams such as Bear Creek. For example, fish communities include several trophic levels and species that are at or near the end of food chains. Consequently, they potentially integrate the direct effects of water quality and habitat changes on primary producers (periphyton) and consumers (benthic invertebrates) that are used for food. Because of these trophic interrelationships, the well-being of fish populations has often been used as an index of water quality (e.g., Weber 1973, Greeson et al. 1977, Karr et al. 1986). Statements about the condition of the fish community are better understood by the general public than are statements about the condition of diatoms or benthic macroinvertebrates (Karr 1981).

The initial objectives of the instream fish monitoring task were (1) to characterize spatial and temporal patterns in the distribution and abundance of fishes in Bear Creek and (2) to document any possible effects on fish community structure and function resulting from implementation of remedial actions in the Bear Creek watershed or from other activities such as construction.
Bear Creek is unique in that the Tennessee dace (Phoxinus tennesseensis) inhabits the stream in relatively high numbers. The Tennessee dace has been classified as a species "deemed in need of management" by the Tennessee Wildlife Resources Agency and as "endangered" by Virginia. There are 47 known past and present locations from which the Tennessee dace has been collected, including two in Virginia. The Tennessee dace is restricted to small headwater streams of the Tennessee River drainage from an area near Chattanooga, Tennessee, northeast into Virginia. In Tennessee, the largest populations of Tennessee dace occur on the Cherokee National Forest, Polk County, and on ORR in Roane and Anderson counties. ORR may offer a stronghold for the species (Etnier and Starnes 1993).

\subsubsection{Methods and Materials}

Quantitative sampling of the fish population was conducted in Bear Creek at seven sites (Fig. 5.1) by electrofishing biannually from spring 1988 through fall 1993. Bear Creek kilometer 0.7 was added as a sampling site beginning in spring 1992. Sampling at this site was begun to monitor any adverse effects from runoff from the White Wing Scrapyard. Similar quantitative samples were made at two nearby reference sites [Grassy Creek kilometer (GCK) 2.4 and Mill Branch kilometer (MBK) 1.6] for comparisons of population parameters (Fig. 5.2). Grassy Creek was sampled from spring 1988 through fall 1992 and Mill Branch was sampled spring 1988 through fall 1993. 




Fig. 5.1. Location of fish community study sampling sites. WT $=$ west tributary, ET $=$ east tributary, ST $=$ south tributary, NT $=$ north tributary, SS = south spring, NS = north spring. 
ORNL-DWG 96-3550




Stream conditions have declined at Grassy Creek; therefore, two sites, Gum Hollow Creek (GHK) 2.9 and Pinhook Branch kilometer (PHK) 1.6, were added as new reference sites beginning in spring 1993. The fish fauna in the upper sites in Bear Creek are also more comparable to Pinhook Branch and Gum Hollow Creek than to Grassy Creek. The resulting data were used to (1) determine species composition, (2) estimate population size (numbers and biomass per unit area), and (3) determine annual production. The lengths of the sampling reaches ranged from 44 to $186 \mathrm{~m}$ at Bear Creek and from 36 to $65 \mathrm{~m}$ at the reference sites

(Table 5.1). Fish sampling sites either overlapped or were within $100 \mathrm{~m}$ of the benthic invertebrate sampling sites. The length of the sampling reaches remained similar throughout the sampling periods, with the exceptions being BCK 12.36 and 11.09. In spring 1991 and again in spring 1992, the sampling reach at BCK 12.36 was decreased in length due to an increase in the number of fish present. The sampling reach is now less than half of the length of the original area sampled. Bear Creek at BCK 11.09 is intermittent during the summer months. This site was not sampled in fall 1991 because the stream was dry at this location. In fall 1993, BCK 11.09 consisted of a series of five pools intermixed with stretches of stream bed; thereby decreasing the length of the sampling reach.

\subsubsection{Field sampling procedures}

All stream sampling was conducted using one or two Smith-Root Model 15A backpack electrofishers, depending on stream size. Each unit has a self-contained, gasoline-powered generator capable of delivering up to $1200 \mathrm{~V}$ of pulsed direct current. A pulse frequency of 90 to $120 \mathrm{~Hz}$ was used, and the output voltage was adjusted to the optimal value (generally 300-500 V) based on the specific conductance of the water. The circular (ring) electrode at the end of the fiberglass anode pole was fitted with a nylon net $(0.64-\mathrm{cm}$ mesh) to allow the electrofisher operator to collect stunned fish.

After 0.64-cm-mesh seines were placed across the upper and lower boundaries of the fish sampling site to restrict fish movement, a two- to seven-person sampling team electrofished the site in an upstream direction on three consecutive passes. If fish numbers captured during the first pass were extremely low or zero, then only one pass was made. Depending upon the turbidity of the water, consecutive passes could not always be made immediately. Rather, fish were processed after each pass to allow sufficient time for the water to clear before another pass was initiated. Stunned fish were collected and stored, by pass, in the stream in buckets with small holes during further sampling. When possible, aerators were used on buckets to reduce mortality.

Following electrofishing, fish were anesthetized with MS-222 (tricaine methanesulfonate), identified, measured to the nearest $0.1 \mathrm{~cm}$ (total length), and weighed on Pesola spring scales to the nearest $0.1 \mathrm{~g}$ (for fish less than $100 \mathrm{~g}$ ) or gram (for fish greater than $100 \mathrm{~g}$ ). Individuals were recorded by $1-\mathrm{cm}$ size classes and species. For spring 1988 through spring 1991 sampling, 25 individuals of a species-size class were measured and weighed, additional members of that size class were only measured. Beginning in fall 1991, 10 individuals of a species-size class were measured and weighed, and additional members of that size class were only measured. Later, length-weight regressions were determined using Railsback et al. (1989) to estimate weights of unweighed fish. Other data recorded (if possible) included sex, 
Table 5.1. Length, mean width, mean depth, surface area, and pool to riffle ratio ( $P / R$ ratio) of fish sampling sites in Bear Creek and the reference streams, Grassy Creek, Gum Hollow, Mill Branch, and Pinhook Branch, for spring and fall sampling periods 1988-93

\begin{tabular}{|c|c|c|c|c|c|c|c|c|c|c|c|c|}
\hline \multirow[b]{2}{*}{ Site $^{a}$} & \multicolumn{2}{|c|}{1988} & \multicolumn{2}{|c|}{1989} & \multicolumn{2}{|c|}{1990} & \multicolumn{2}{|c|}{1991} & \multicolumn{2}{|c|}{1992} & \multicolumn{2}{|c|}{1993} \\
\hline & Spring $^{b}$ & Fall $^{c}$ & Spring & Fall & Spring & Fall & Spring & Fall & Spring & Fall & Spring & Fall \\
\hline BCK 0.7 & $\mathrm{NS}^{d}$ & NS & NS & NS & NS & NS & NS & NS & & & & \\
\hline Length (m) & & & & & & & & & 102 & 90 & 90 & 95 \\
\hline Width (m) & & & & & & & & & 5.6 & 5.4 & 5.4 & 4.7 \\
\hline Area $\left(\mathrm{m}^{2}\right)$ & & & & & & & & & 571 & 486 & 486 & 447 \\
\hline Depth $(\mathrm{cm})$ & & & & & & & & & 18.3 & 9.9 & 18.0 & 11.2 \\
\hline $\mathrm{P} / \mathrm{R}$ ratio & & & & & & & & & 0.5 & 1.3 & 0.8 & 1.5 \\
\hline \multicolumn{13}{|l|}{ BCK 3.25} \\
\hline Length & 57 & 57 & 57 & 66 & 60 & 65 & 65 & 55 & 55 & 59 & 55 & 56 \\
\hline Width & 5.2 & 5.3 & 5.7 & 4.9 & 5.1 & 4.5 & 5.3 & 4.9 & 4.8 & 4.8 & 5.6 & 5.2 \\
\hline Area & 296 & 302 & 325 & 323 & 306 & 293 & 345 & 270 & 264 & 283 & 308 & 291 \\
\hline Depth & 11.8 & 11.0 & 15.8 & 4.9 & 17.3 & 12.5 & 25.3 & 19.0 & 14.6 & 21.0 & 24.3 & 17.5 \\
\hline P/R ratio & $\mathrm{NM}^{e}$ & NM & 0.3 & 0.8 & $\mathrm{P}^{f}$ & 0.9 & 0.8 & 4.5 & 2.2 & 3.2 & 2.2 & 6.0 \\
\hline \multicolumn{13}{|l|}{ BCK 7.87} \\
\hline Length & 48 & 45 & 44 & 48 & 46 & 46 & 49 & 47 & 46 & 47 & 49 & 48 \\
\hline Width & 3.1 & 3.4 & 3.2 & 3.5 & 3.6 & 3.5 & 3.6 & 3.6 & 3.7 & 3.8 & 3.8 & 3.4 \\
\hline Area & 149 & 153 & 141 & 168 & 166 & 161 & 176 & 155 & 170 & 179 & 186 & 163 \\
\hline Depth & 15.0 & 24.6 & 17.8 & 15.9 & 15.9 & 14.9 & 20.0 & 16.9 & 20.6 & 18.3 & 22.9 & 15.7 \\
\hline $\mathrm{P} / \mathrm{R}$ ratio & NM & NM & 3.9 & 23.0 & $\mathrm{P}$ & 10.5 & 3.9 & 22.5 & 2.5 & 1.9 & 2.3 & 15.0 \\
\hline \multicolumn{13}{|l|}{ BCK 9.40} \\
\hline Length & 71 & 60 & 57 & 60 & 60 & 65 & 58 & 62 & 63 & 60 & 62 & 57 \\
\hline Width & 2.5 & 2.8 & 3.4 & 3.0 & 3.2 & 2.3 & 3.1 & 2.5 & 3.0 & 2.8 & 2.9 & 3.0 \\
\hline Area & 178 & 168 & 194 & 180 & 192 & 150 & 180 & 155 & 189 & 168 & 180 & 171 \\
\hline Depth & 10.7 & 13.2 & 16.8 & 13.5 & 17.9 & 11.0 & 14.6 & 9.6 & 13.5 & 12.8 & 12.5 & 8.7 \\
\hline $\mathrm{P} / \mathrm{R}$ ratio & NM & NM & 0.7 & 1.1 & $\mathrm{P}$ & 1.7 & 0.9 & 2.4 & 0.9 & 0.7 & 0.6 & 1.5 \\
\hline
\end{tabular}


Table 5.1 (continued)

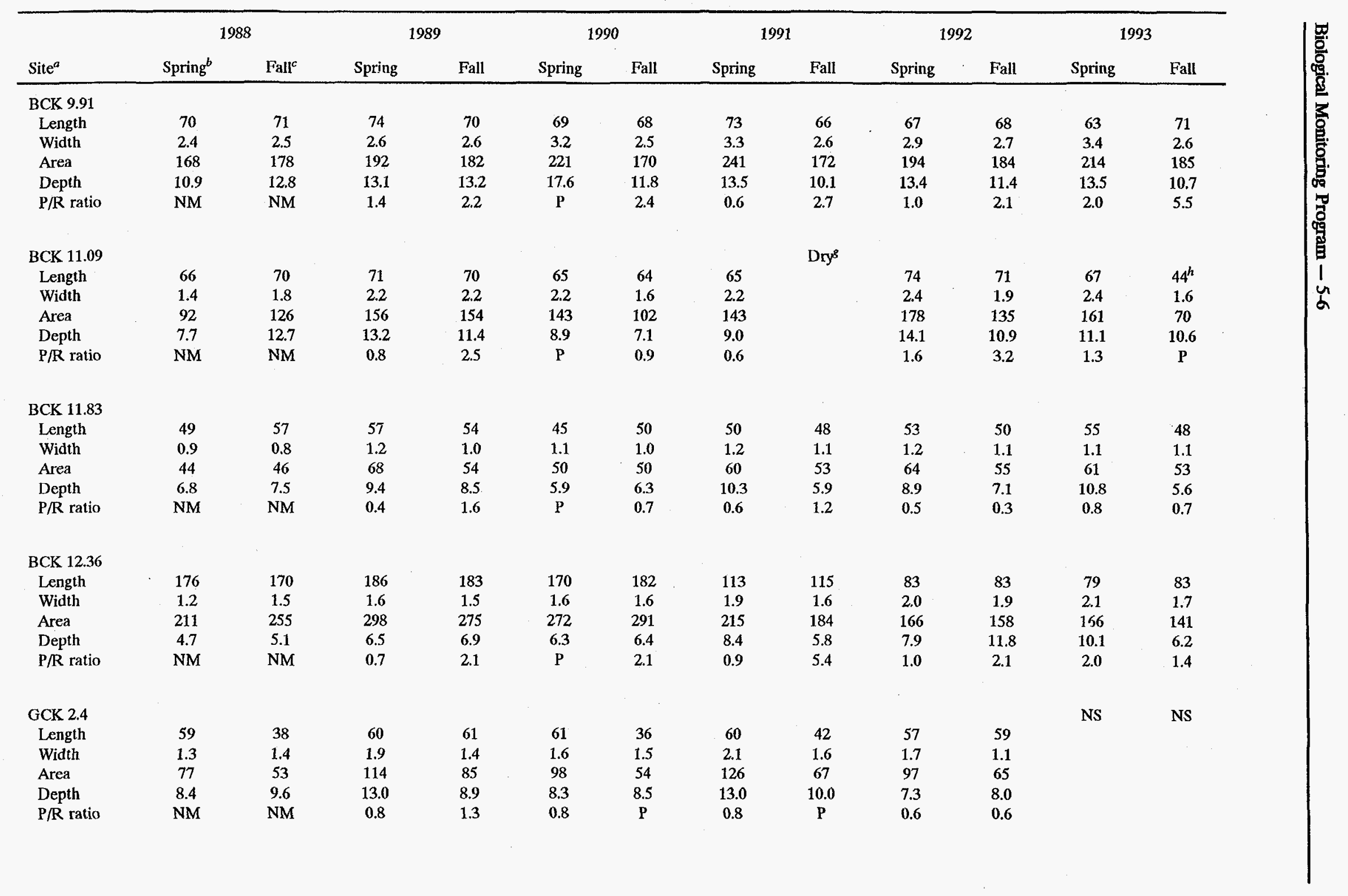


Table 5.1 (continued)

\begin{tabular}{|c|c|c|c|c|c|c|c|c|c|c|c|c|}
\hline \multirow[b]{2}{*}{ Site $^{a}$} & \multicolumn{2}{|c|}{1988} & \multicolumn{2}{|c|}{1989} & \multicolumn{2}{|c|}{1990} & \multicolumn{2}{|c|}{1991} & \multicolumn{2}{|c|}{1992} & \multicolumn{2}{|c|}{1993} \\
\hline & Spring ${ }^{b}$ & Fall & Spring & Fall & Spring & Fall & Spring & Fall & Spring & Fall & Spring & Fall \\
\hline GHK 2.9 & NS & NS & NS & NS & NS & NS & NS & NS & NS & NS & & \\
\hline Length & & & & & & & & & & & 65 & 65 \\
\hline Width & & & & & & & & & & & 1.4 & 1.0 \\
\hline Area & & & & & & & & & & & 91 & 6.5 \\
\hline Depth & & & & & & & & & & & 7.6 & 5.4 \\
\hline $\mathrm{P} / \mathrm{R}$ ratio & & & & & & & & & & & 2.4 & 2.0 \\
\hline \multicolumn{13}{|l|}{ MBK 1.6} \\
\hline Length & 49 & 47 & 50 & 49 & 50 & 51 & 52 & 55 & 53 & 55 & 58 & 52 \\
\hline Width & 3.0 & 3.0 & 3.1 & 2.9 & 3.1 & 3.0 & 3.4 & 2.9 & 3.5 & 3.0 & 3.6 & 3.0 \\
\hline Area & 147 & 141 & 155 & 142 & 155 & 153 & 177 & 160 & 186 & 165 & 209 & 156 \\
\hline Depth & 9.0 & 9.7 & 11.6 & 9.9 & 10.2 & 8.1 & 11.0 & 9.6 & 10.4 & 8.2 & 10.1 & 8.2 \\
\hline $\mathrm{P} / \mathrm{R}$ ratio & NM & NM & 0.7 & 1.9 & 0.9 & 1.3 & 0.6 & 2.1 & 0.5 & 1.8 & 0.8 & 1.4 \\
\hline PHK 1.6 & NS & NS & NS & NS & NS & NS & NS & NS & NS & NS & & \\
\hline Length & & & & & & & & & & & 65 & 65 \\
\hline Width & & & & & & & & & & & 1.3 & 1.2 \\
\hline Area & & & & & & & & & & & 85 & 78 \\
\hline Depth & & & & & & & & & & & 6.7 & 4.9 \\
\hline $\mathrm{P} / \mathrm{R}$ ratio & & & & & & & & & & & 1.6 & 2.8 \\
\hline
\end{tabular}

${ }^{a} \mathrm{BCK}=$ Bear Creek kilometer, GCK $=$ Grassy Creek kilometer, GHK $=$ Gum Hollow kilometer, MRK $=$ Mill Branch kilometer, PHK $=$ Pinhook Branch kilometer.

${ }^{b}$ Sampling in the spring periods was conducted in March through April.

'Sampling in the fall periods was conducted in october through December.

${ }^{d} \mathrm{NS}=$ not sampled.

${ }^{e} \mathrm{NM}=$ not measured.

$f_{\mathrm{P}}=$ Section of the stream sampled was considered pool.

${ }^{8}$ Dry $=$ site was dry and could not be sampled.

${ }^{h}$ Site consisted of a series of five pools. 
reproductive state, whether the fish was unusually plump or emaciated, disposition (i.e., released, deceased, or retained for laboratory identification and reference collection), and presence of any abnormalities (e.g., external parasites, skeletal deformities, etc.). After processing fish from all passes, the fish were allowed to recover fully from the anesthesia and were returned to the stream. Any additional mortality that occurred as a result of processing was noted at that time.

In addition to data on individual fish, selected physical and chemical parameters were measured, and sampling effort was recorded. An Horiba Model U-7 batterypowered field sampler was used to measure conductivity, $\mathrm{pH}$, water temperature, and dissolved oxygen content. An HF Instruments Model DRT-15 turbidimeter was used to measure turbidity. The duration of the electrofishing effort was recorded and a visual estimate was made of percent cloud cover. Following completion of fish sampling, the length, width, and depth of the sampling $i$ each were measured at each site.

\subsubsection{Data analysis}

Population size. Species population estimates were obtained using the threepass removal method of Carle and Strub (1978). Biomass was estimated by multiplying the population estimate by the mean weight of the individual. To calculate density and biomass per unit area, total numbers and biomass were divided by the water surface area $\left(\mathrm{m}^{2}\right)$ of the study reach. For each sampling date, surface area was estimated by multiplying the length of the sampling reach by the mean width based on measurements taken at $5-\mathrm{m}$ intervals (Table 5.1). These data were compiled and analyzed by a comprehensive Fortran 77 program developed by Railsback et al. (1989).
Annual production. Annual production was estimated using a sizefrequency method (Garman and Waters 1983). Production was calculated for each site (where data was available) from the spring of one year to the following spring, beginning in 1988 through 1993.

Production values were calculated from estimated biomass and population estimates. Annual production estimates for Bear Creek were compared to values for Grassy Creek and Mill Branch.

\subsubsection{Results and Discussion}

\subsubsection{Species richness and composition}

A total of 19 species were collected in the quantitative surveys of the 8 sites in Bear Creek from spring 1988 through fall 1993 (Table 5.2). In comparison, a total of 3 species were found in both Gum Hollow Creek and in Pinhook Branch, 6 species were found at Grassy Creek, and 11 species were found in Mill Branch. Of the 19 species found in Bear Creek, 11 were found at one or both of the two lowermost sites, BCK 0.7 and 3.3, but not at the upstream sites. There is a weir at BCK 4.55 which limits fish movement upstream, as indicated by the absence of fish species upstream. Eight species were found above the weir at BCK 4.55 and downstream of BCK 11.83 , while only four species were found at the uppermost sites (BCK 11.83 and 12.36).

The patterns observed in species richness during the 1988-93 sampling periods were similar to those observed in 1984-87 (Southworth et al. 1992). The blacknose dace (Rhinichthys atratulus) and creek chub (Semotilus atromaculatus) were found at all eight sites sampled in Bear Creek. These two fish species were also found at the four reference sites. The central stoneroller (Campostoma 
Table 5.2. Fish species composition in Bear Creek and in four reference streams, Gum Hollow Creek, Pinhook Branch, Grassy Creek, and Mill Branch, for March through May 1988-93 and October through December 1988-93

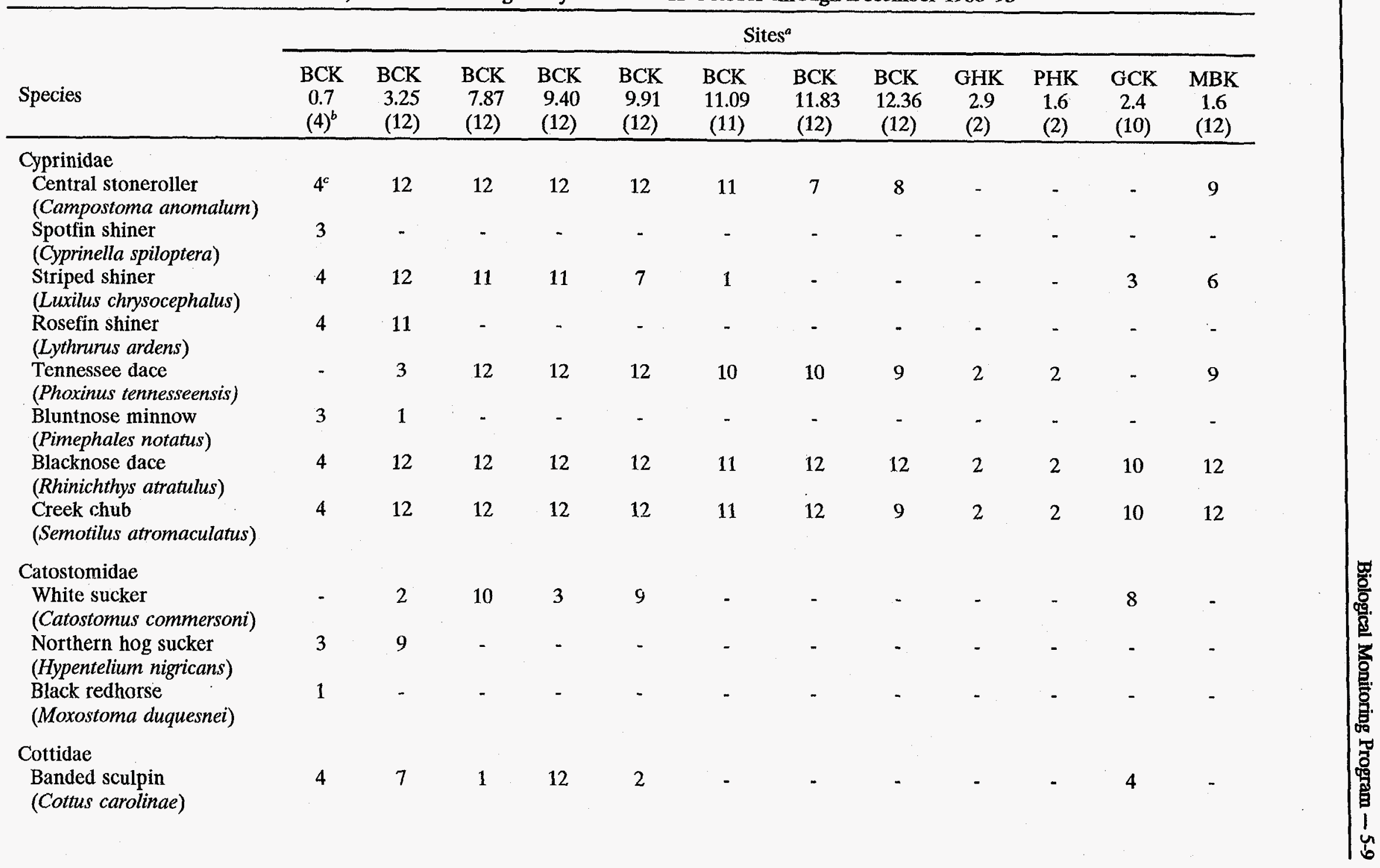


Table 5.2 (continued)

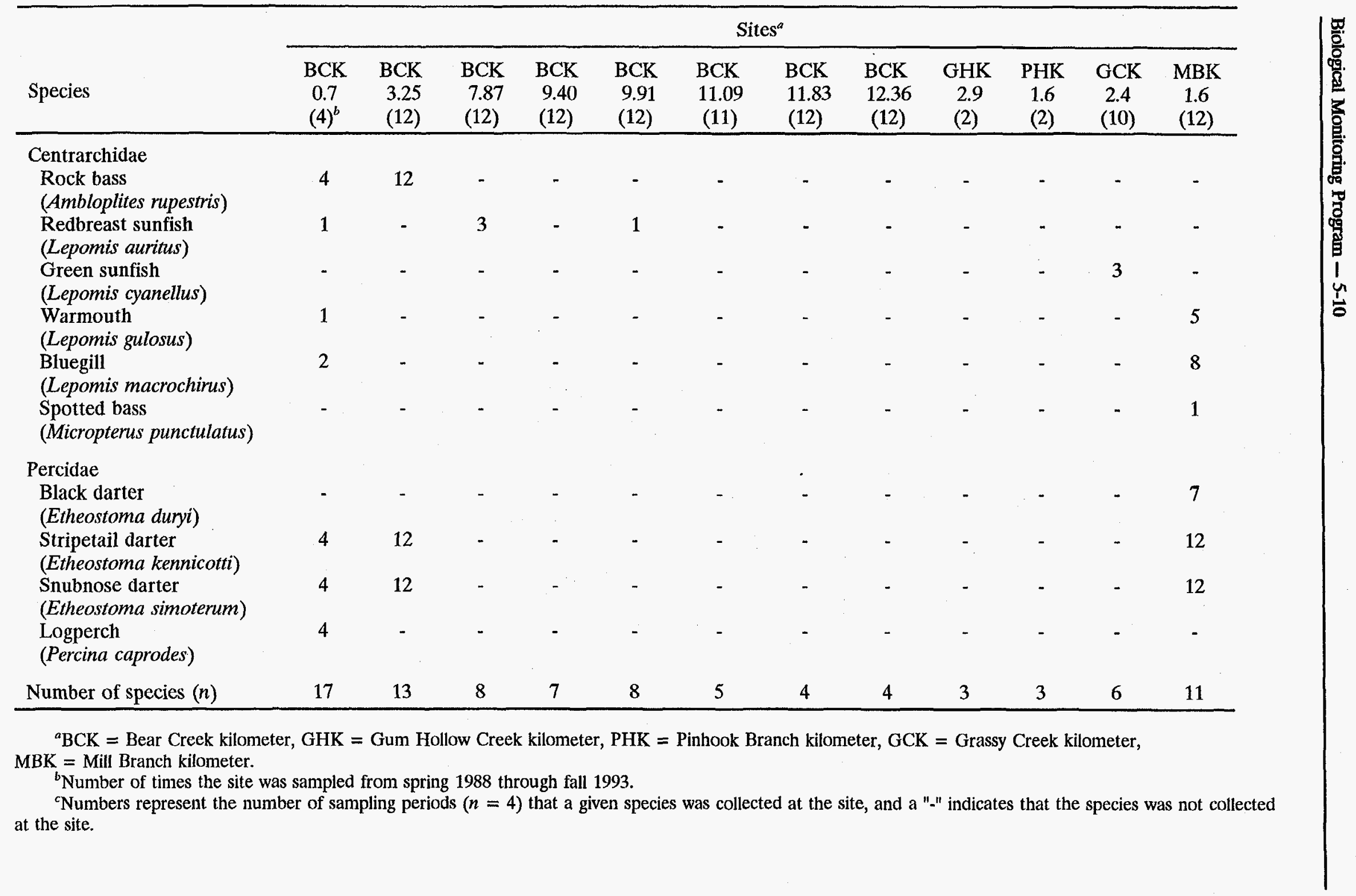


anomalum) was also found at all eight sites in Bear Creek but was oniy found at one reference site, Mill Branch. The Tennessee dace was found at all Bear Creek and reference sites except BCK 0.7 and GCK 2.4 .

Generally, any changes that occurred in fish community composition were the result of an increase rather than a decrease in species richness at a site. The frequency of occurrence of certain species also increased during the 1988-93 sampling period compared with 1984-87.

The greatest change in species composition occurred at BCK 12.36. The central stoneroller was not found at this site during the 1984-87 sampling periods. During 1988-93, the central stoneroller was found in 8 of 12 sampling periods. The central stoneroller was first found in spring 1990 and has been collected during each sampling period at $\mathrm{BCK} 12.36$ since then. The presence of Tennessee dace increased from 1 of 8 sampling periods in 1984-87 to 9 of 12 sampling periods in 1988-93. The presence of the creek chub increased from 3 of 8 sampling periods in 1984-87 to 9 of 12 sampling periods in 1988-93. The Tennessee dace and creek chub have been found each sampling period at BCK 12.36 beginning in fall 1989.

Only minor changes occurred in species composition at BCK 3.25 during the 1988-93 sampling period. Sampling did not reveal the emerald shiner (Notropis atherinoides) or the spotfin shiner (Cyprinella spiloptera) at BCK 3.25. During the 1984-87 sampling periods, these fish were found once during the eight sampling periods. The bluntnose minnow (Pimephales notatus) was found at BCK 3.25 in 1 of 12 sampling periods during 1988-93, but was not found previously.

Sampling at BCK 7.87 during 1988-93 revealed redbreast sunfish (Lepomis auritus) and the banded sculpin (Cottus carolinae) in 3 of 12 and 1 of 12 sampling periods, respectively. These species had not been previously collected at this site.

The species occurrence at BCK 9.91 did not change dramatically, but additional species were found during the 1988-93 sampling period. The redbreast sunfish was found in 1 of 12 sampling periods at BCK 9.91 during 1988-93 and had not been previously found. The striped shiner (Luxilus chrysocephalus) increased in occurrence from 1 of 8 sampling periods in $1984-87$ to 7 of 12 sampling periods in 1988-93 at BCK 9.91. The white sucker (Catostomus commersoni) increased in occurrence from 2 of 8 sampling periods in 1984-87 to 9 of 12 sampling periods in 1988-93 at BCK 9.91.

The striped shiner was found in 1 of 11 sampling periods at $\mathrm{BCK} 11.09$ during 1988-93 and had not been previously found.

Species richness remained the same but the species composition changed at the reference site GCK 2.4 from previous sampling. During 1984-87, the central stoneroller was found in 3 of 8 sampling periods. The central stoneroller was absent from GCK 2.4 during 1988-92. The green sunfish (Lepomis cyanellus) was not found previously during the 1984-87 sampling period but was found in 3 of 10 sampling periods during 1988-93. The green sunfish was not found at any other reference sites or in Bear Creek and is considered a species tolerant to water quality and/or habitat degradation. The other fish species found at GCK 2.4, striped shiner, blacknose dace, creek chub, and white sucker, decreased in the proportion of times the species was found in 1988-93 compared with the 1984-87 sampling periods.

Species richness increased only slightly at Mill Branch in 1988-93. Spotted bass (Micropterus punctulatus) were found in 1 of 12 sampling periods during the 1988-93 sampling period but were not found previously. The spotted bass may have 
originated in ponds from a golf course, located upstream of the sampling site. The black darter (Etheostoma duryi) was found in 7 of 12 sampling periods in 1988-93. This species was thought to be present in the 1984-87 sampling period but was not distinguished from the snubnose darter ( $E$. simoterum) (Southworth et al. 1992).

The fish community in Pinhook Branch and Gum Hollow Creek consisted of three species, Tennessee dace, blacknose dace, and creek chub. The upper sites (e.g., BCK 11.09, 11.83, and 12.36) in Bear Creek are more similar to these two reference sites than to Grassy Creek.

Unlike Mill Branch, BCK 7.87, 9.40, and 9.91 are lacking the darter species. These sites are also lacking the northern hog sucker (Hypentelium nigricans) and rock bass (Ambloplites rupestris), which were found downstream at BCK 3.25 and 0.7 . The absence of these species is most likely attributable to the presence of a weir at BCK 4.55, which acts as a barrier to fish migration upstream.

\subsubsection{Density and biomass}

Population surveys of Bear Creek and the reference sites were conducted twice a year (spring and fall), and the data were used to estimate species density and biomass for each perioc. The total estimated density and biomass at each site for each sampling period are presented in Table 5.3. Values for individual species are given in Appendix B, Tables B.1 through B.24. In general, estimated total fish densities and biomass did not demonstrate any persistent pattern with distance upstream over the six years of sampling (Figs. 5.3 through 5.8). Total estimated density of the Tennessee dace are presented in Figs. 5.9 and 5.10.
In general, quantitative estimates of density were higher during the fall sampling than in spring sampling (Table 5.3, Figs. 5.3 through 5.5). The fact that fall densities were higher reflects recruitment of fish into the community and normally characterized all sites. Higher fall densities have also been documented in other watersheds such as East Fork Poplar Creek, White Oak Creek, and Mitchell Branch (Ryon 1993; Ryon and Schilling 1994; Schilling 1993, 1994, 1995). All sites in Bear Creek and Mill Branch did exhibit at least one fall period in which density was lower than in the previous spring sample period. Total estimated density at BCK 11.09 was lower in the fall than the spring in four out of six sampling periods. Fall sampling may reflect the fact that BCK 11.09 is dry to intermittent during parts of the summer and fall. BCK 3.25 and 0.7 have not exhibited as much variation in density between spring and fall sampling as the other sites.

Fish populations have remained fairly stable at BCK 0.7 and 3.25 in terms of density and biomass. Density and biomass increased at BCK 3.25 in fall 1991 and spring 1992 but declined after spring 1992 to previous levels. Tennessee dace are more of a headwater species and are found infrequently at BCK 0.7 or 3.25 (Fig. 5.9).

Total estimated fish density and biomass at BCK 7.87 were depressed in fall 1989 through spring 1991, compared with other sampling periods. All species indicated a decline in density. The decrease in biomass was not as pronounced as the decrease in density during this time period.

The Tennessee dace exhibited a decline in density at BCK 7.87 from spring 1988 through fall 1990 (Fig. 5.9). Density increased in spring 1991 but then decreased and remained fairly constant until an increase in fall 1993. The fall 1993 density was $<50 \%$ of the spring 1988 
Table 5.3. Total fish density (number of fish per square meter), total biomass (grams of fish per square meter), and species richness in Bear Creek and in four reference streams, Gum Hollow Creek, Pinhook Branch, Grassy Creek, and Mill Branch, for March through May, 1988-93 and October through December, 1988-93

\begin{tabular}{|c|c|c|c|c|c|c|c|c|c|c|c|c|}
\hline \multirow[b]{2}{*}{ Sampling periods } & \multicolumn{12}{|c|}{ Sites $^{a}$} \\
\hline & $\underset{0.7}{\mathrm{BCK}}$ & $\begin{array}{r}\text { BCK } \\
3.25\end{array}$ & $\begin{array}{r}\text { BCK } \\
7.87\end{array}$ & $\begin{array}{r}\text { BCK } \\
9.40\end{array}$ & $\begin{array}{r}\mathrm{BCK} \\
9.91\end{array}$ & $\begin{array}{l}\text { BCK } \\
11.09\end{array}$ & $\begin{array}{l}\text { BCK } \\
11.83\end{array}$ & $\begin{array}{l}\text { BCK } \\
12.36\end{array}$ & $\underset{2.9}{\mathrm{GHK}}$ & $\begin{array}{c}\text { PHK } \\
1.6\end{array}$ & $\begin{array}{c}\text { GCK } \\
2.4\end{array}$ & $\underset{1.6}{\text { MBK }}$ \\
\hline $\begin{array}{l}\text { March } 1988 \\
\text { Total density } \\
\text { Total biomass } \\
\text { Species richness }\end{array}$ & $\mathbf{N S}^{b}$ & $\begin{array}{c}1.68 \\
4.25 \\
12\end{array}$ & $\begin{array}{c}3.23 \\
5.56 \\
6\end{array}$ & $\begin{array}{c}2.11 \\
4.19 \\
6\end{array}$ & $\begin{array}{c}2.08 \\
7.17 \\
5\end{array}$ & $\begin{array}{c}1.44 \\
4.17 \\
4\end{array}$ & $\begin{array}{c}0.62 \\
2.28 \\
2\end{array}$ & $\begin{array}{c}0.01 \\
0.02 \\
1\end{array}$ & NS & NS & $\begin{array}{c}0.62 \\
1.08 \\
3\end{array}$ & $\begin{array}{c}2.23 \\
3.24 \\
9\end{array}$ \\
\hline $\begin{array}{l}\text { October-December } \\
\text { Total density } \\
\text { Total biomass } \\
\text { Species richness }\end{array}$ & NS & $\begin{array}{c}1.46 \\
2.56 \\
9\end{array}$ & $\begin{array}{c}4.75 \\
4.57 \\
6\end{array}$ & $\begin{array}{c}2.03 \\
3.42 \\
6\end{array}$ & $\begin{array}{c}2.27 \\
4.42 \\
5\end{array}$ & $\begin{array}{c}0.61 \\
0.86 \\
4\end{array}$ & $\begin{array}{c}1.67 \\
2.78 \\
4\end{array}$ & $\begin{array}{c}0.01 \\
0.01 \\
1\end{array}$ & NS & NS & $\begin{array}{c}1.55 \\
2.75 \\
2\end{array}$ & $\begin{array}{c}2.08 \\
1.75 \\
6\end{array}$ \\
\hline $\begin{array}{l}\text { March-April } 1989 \\
\text { Total density } \\
\text { Total biomass } \\
\text { Species richness }\end{array}$ & NS & $\begin{array}{c}0.92 \\
1.96 \\
9\end{array}$ & $\begin{array}{c}4.86 \\
12.48 \\
6\end{array}$ & $\begin{array}{c}1.22 \\
3.26 \\
6\end{array}$ & $\begin{array}{c}1.62 \\
4.52 \\
7\end{array}$ & $\begin{array}{c}1.39 \\
3.26 \\
4\end{array}$ & $\begin{array}{c}1.33 \\
3.48 \\
4\end{array}$ & $\begin{array}{c}0.12 \\
0.41 \\
1\end{array}$ & NS & NS & $\begin{array}{c}0.25 \\
0.91 \\
4\end{array}$ & $\begin{array}{c}1.48 \\
2.18 \\
7\end{array}$ \\
\hline $\begin{array}{l}\text { October-November } \\
\text { Total density } \\
\text { Total biomass } \\
\text { Species richness }\end{array}$ & NS & $\begin{array}{c}0.77 \\
1.70 \\
8\end{array}$ & $\begin{array}{c}2.37 \\
4.27 \\
5\end{array}$ & $\begin{array}{c}3.20 \\
7.28 \\
6\end{array}$ & $\begin{array}{c}2.62 \\
6.50 \\
6\end{array}$ & $\begin{array}{c}3.14 \\
5.25 \\
4\end{array}$ & $\begin{array}{c}3.52 \\
5.37 \\
4\end{array}$ & $\begin{array}{c}1.79 \\
1.73 \\
3\end{array}$ & NS & NS & $\begin{array}{c}2.65 \\
5.09 \\
5\end{array}$ & $\begin{array}{c}1.21 \\
2.54 \\
8\end{array}$ \\
\hline $\begin{array}{l}\text { March-April } 1990 \\
\text { Total density } \\
\text { Total biomass } \\
\text { Species richness }\end{array}$ & NS & $\begin{array}{c}0.71 \\
2.43 \\
9\end{array}$ & $\begin{array}{c}2.43 \\
5.21 \\
5\end{array}$ & $\begin{array}{c}1.14 \\
3.55 \\
6\end{array}$ & $\begin{array}{c}2.20 \\
10.28 \\
6\end{array}$ & $\begin{array}{c}3.02 \\
7.49 \\
4\end{array}$ & $\begin{array}{c}3.10 \\
5.40 \\
4\end{array}$ & $\begin{array}{c}1.50 \\
3.21 \\
4\end{array}$ & NS & NS & $\begin{array}{c}1.25 \\
3.47 \\
5\end{array}$ & $\begin{array}{c}0.99 \\
2.87 \\
9\end{array}$ \\
\hline $\begin{array}{l}\text { October-November } \\
\text { Total density } \\
\text { Total biomass } \\
\text { Species richness }\end{array}$ & NS & $\begin{array}{c}0.99 \\
2.01 \\
9\end{array}$ & $\begin{array}{c}2.08 \\
5.27 \\
5\end{array}$ & $\begin{array}{c}3.87 \\
6.13 \\
6\end{array}$ & $\begin{array}{c}2.02 \\
5.33 \\
6\end{array}$ & $\begin{array}{c}1.08 \\
3.42 \\
4\end{array}$ & $\begin{array}{c}2.42 \\
2.43 \\
4\end{array}$ & $\begin{array}{c}1.00 \\
1.82 \\
4\end{array}$ & NS & NS & $\begin{array}{c}3.41 \\
5.80 \\
3\end{array}$ & $\begin{array}{c}1.34 \\
4.35 \\
8\end{array}$ \\
\hline $\begin{array}{l}\text { March-April } 1991 \\
\text { Total density } \\
\text { Total biomass } \\
\text { Species richness }\end{array}$ & NS & $\begin{array}{c}0.78 \\
3.40 \\
9\end{array}$ & $\begin{array}{c}1.80 \\
6.18 \\
6\end{array}$ & $\begin{array}{c}2.16 \\
5.34 \\
7\end{array}$ & $\begin{array}{c}1.93 \\
7.49 \\
6\end{array}$ & $\begin{array}{c}2.05 \\
5.65 \\
4\end{array}$ & $\begin{array}{c}1.64 \\
2.86 \\
3\end{array}$ & $\begin{array}{c}1.58 \\
3.85 \\
4\end{array}$ & NS & NS & $\begin{array}{c}0.41 \\
1.84 \\
4\end{array}$ & $\begin{array}{c}0.94 \\
2.89 \\
9\end{array}$ \\
\hline
\end{tabular}


Table 5.3 (continued)

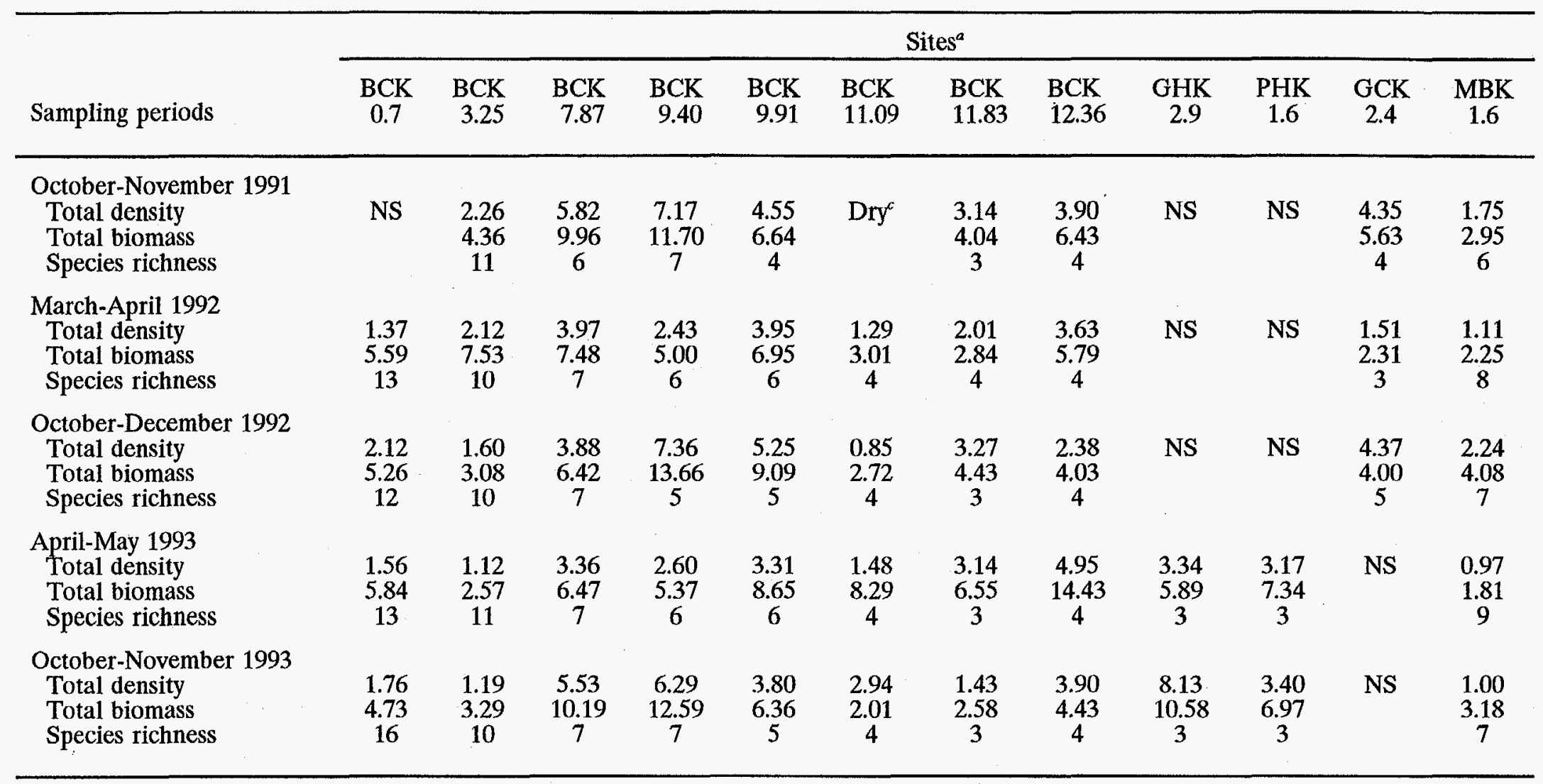

${ }^{a} \mathrm{BCK}=$ Bear Creek kilometer, GHK $=$ Gum Hollow Creek kilometer, PHK $=$ Pinhook Branch kilometer, GCK $=$ Grassy Creek kilometer, MBK $=$ Mill Branch kilometer.

${ }^{b}$ Not sampled.

${ }^{c}$ Site not sampled during this sample season because the stream was dry. 


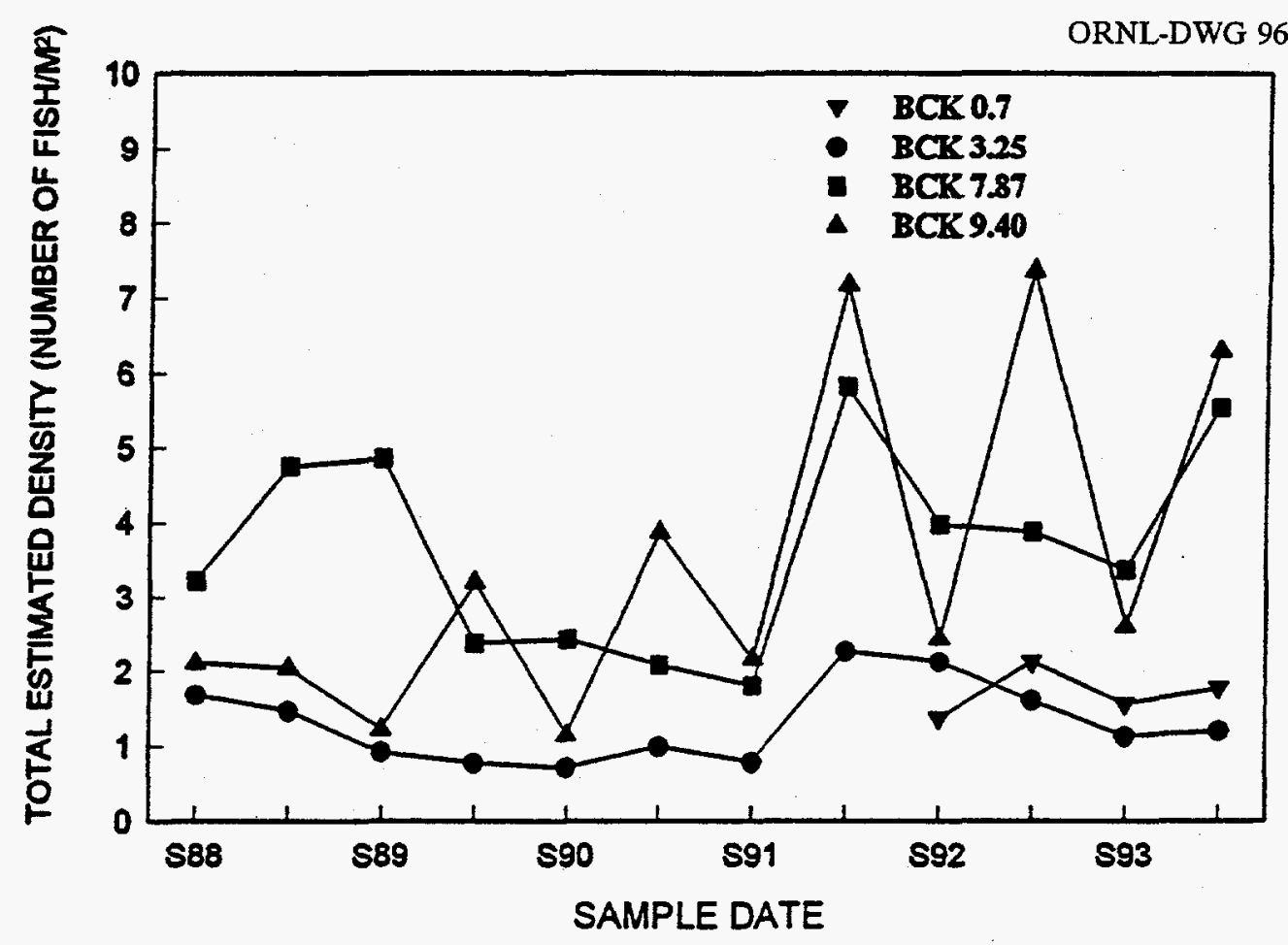

Fig. 5.3. Total estimated fish density (number of fish/m²) in Bear Creek (BCK), spring 1988-fall 1993. BCK = Bear Creek kilometer.

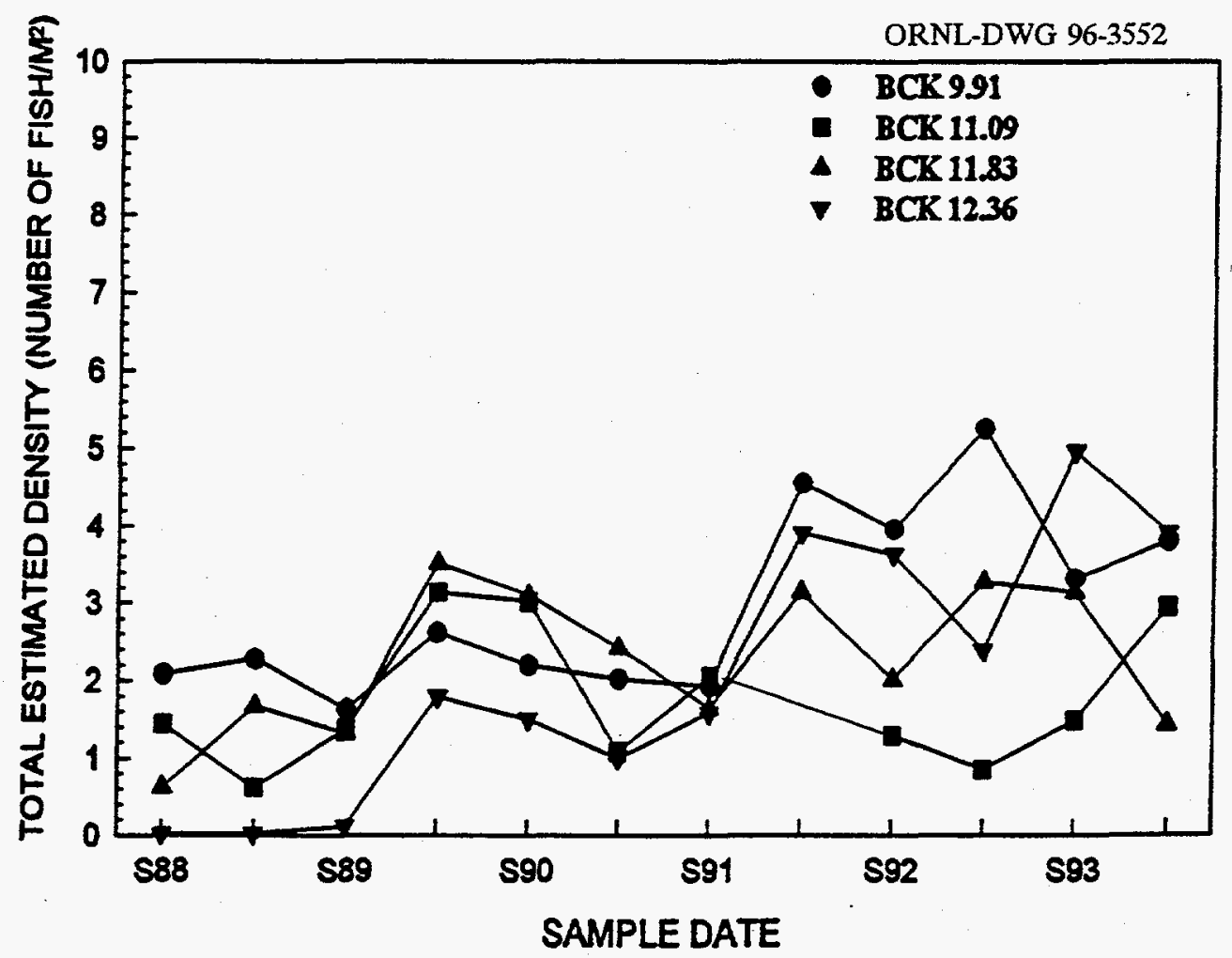

Fig. 5.4. Total estimated fish density (number of fish/m $\mathbf{m}^{2}$ ) in Bear Creek (BCK), spring 1988-fall 1993. BCK = Bear Creek kilometer. 


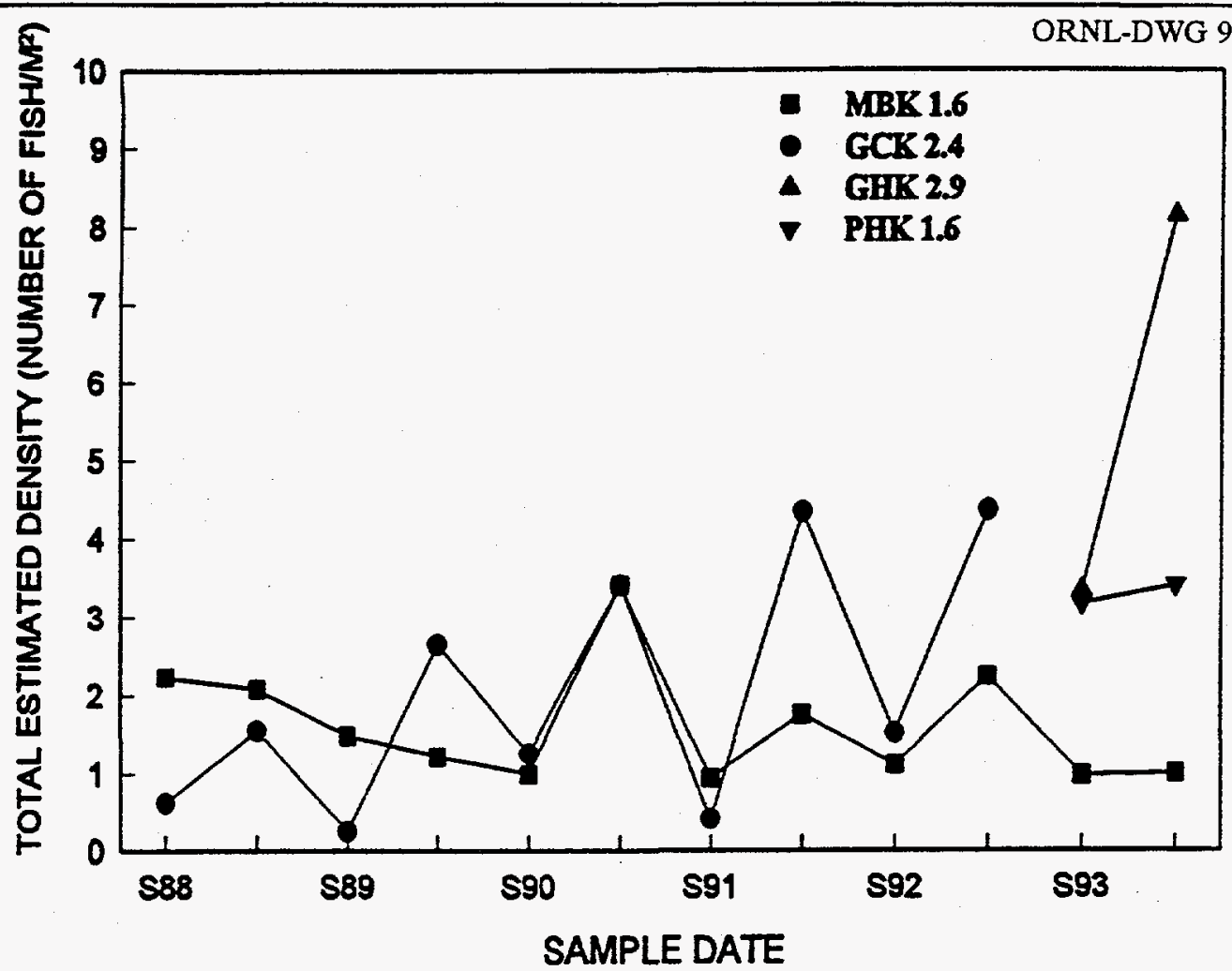

Fig. 5.5. Total estimated fish density (number of fish/ $\mathrm{m}^{2}$ ) in Mill Branch, Grassy Creek, Gum Hollow Creek, and Pinhook Branch, spring 1988-fall 1993. MBK = Mill Branch kilometer; GCK $=$ Grassy Creek kilometer; GHK = Gum Hollow kilometer; PHK $=$ Pinhook kilometer.

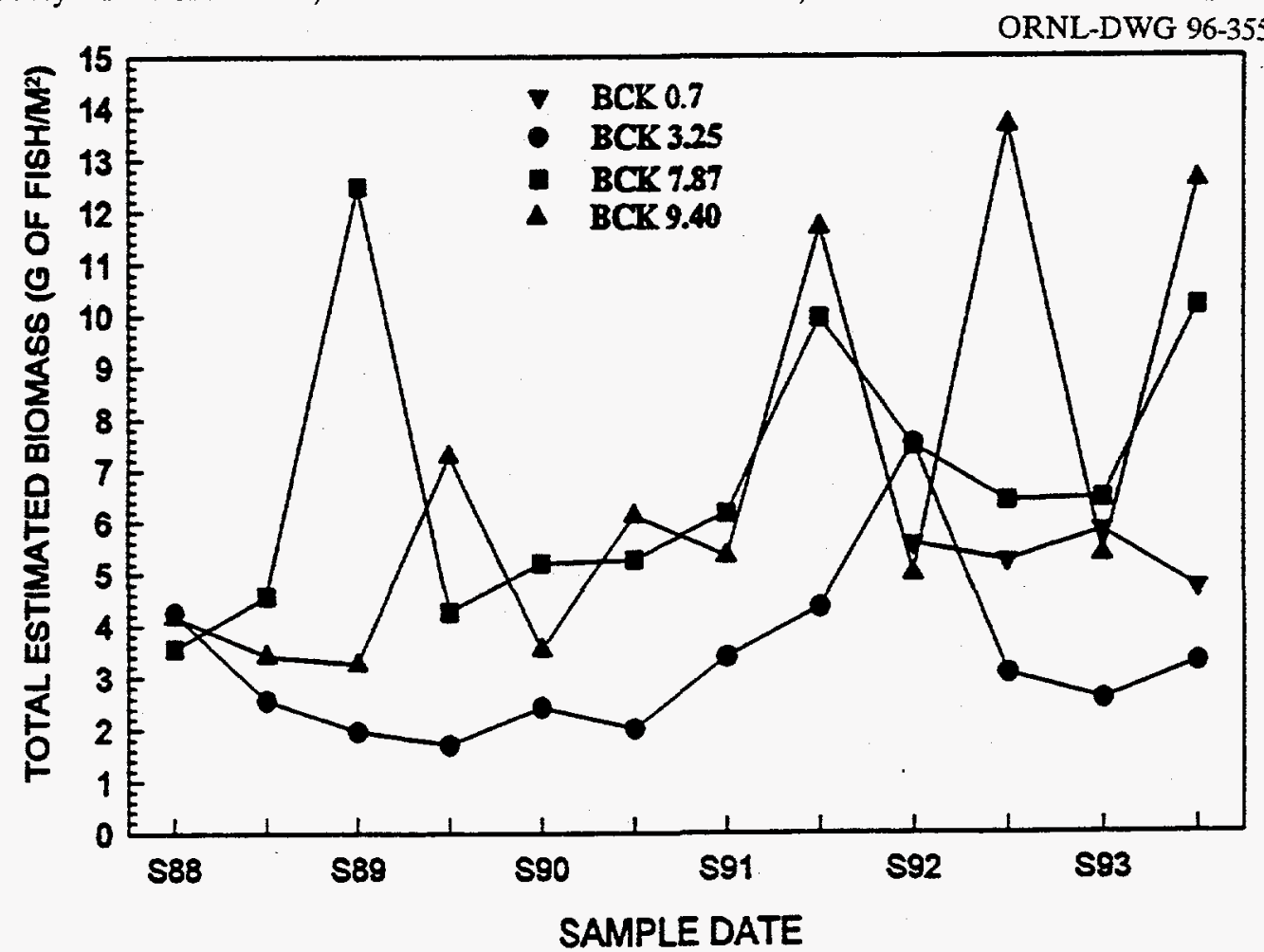

Fig. 5.6. Total estimated fish biomass (grams of fish/m $\mathrm{m}^{2}$ ) in Bear Creek (BCK), spring 1988-fall 1993. $\mathrm{BCK}=$ Bear Creek kilometer. 




Fig. 5.7. Total estimated fish biomass (grams of fish/m²) in Bear Creek (BCK), spring 1988-fall 1993. BCK = Bear Creek kilometer.



Fig. 5.8. Total estimated fish biomass (grams of fish/ $\mathrm{m}^{2}$ ) in Mill Branch, Grassy Creek, Gum Hollow Creek, and Pinhook Branch, spring 1988-fall 1993. MBK = Mill Branch kilometer; GCK $=$ Grassy Creek kilometer; GHK $=$ Gum Hollow kilometer; PHK $=$ Pinhook kilometer. 


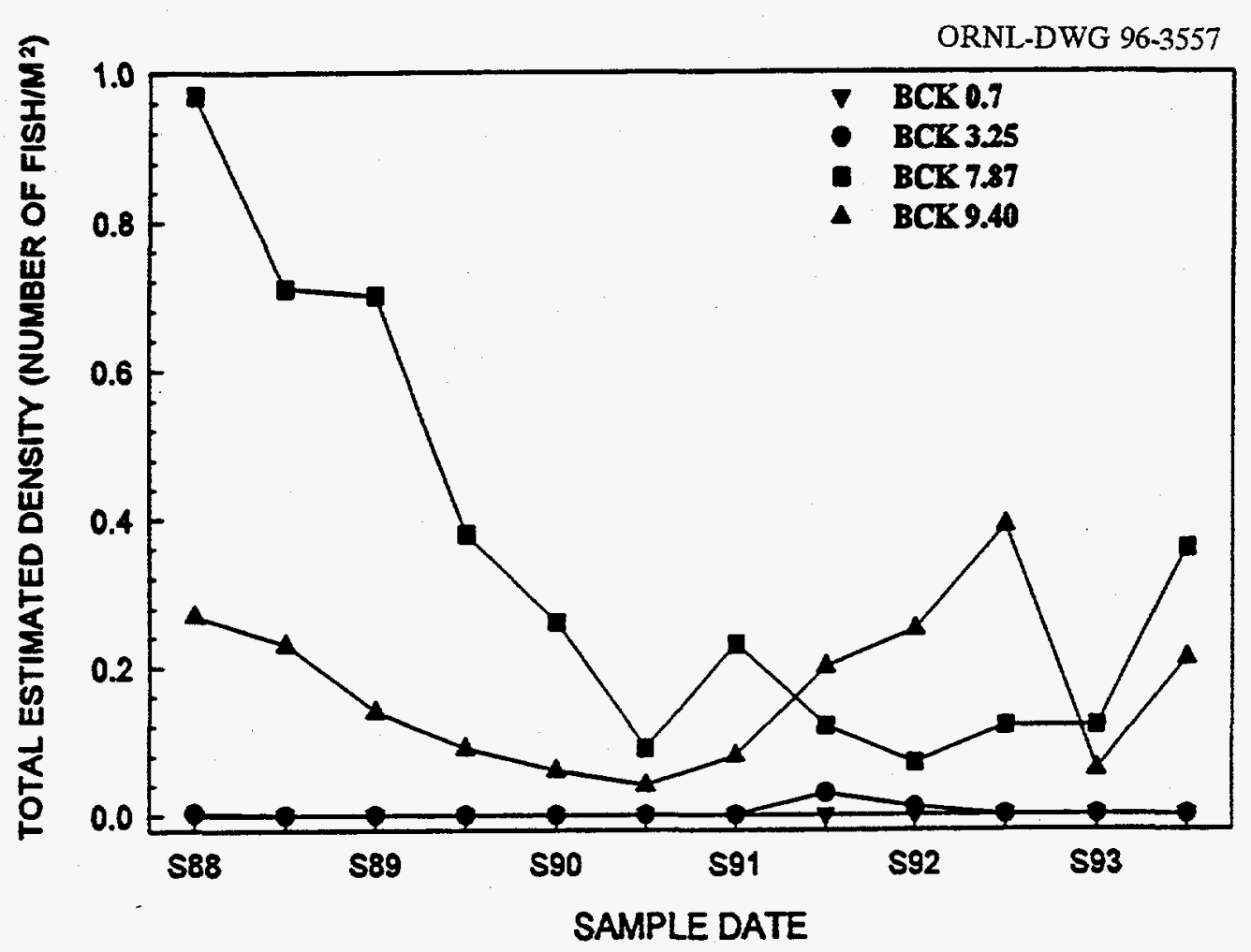

Fig. 5.9. Total estimated Tennessee dace density (number of fish $/ \mathrm{m}^{2}$ ) in Bear Creek (BCK), spring 1988-fall 1993. BCK = Bear Creek kilometer.

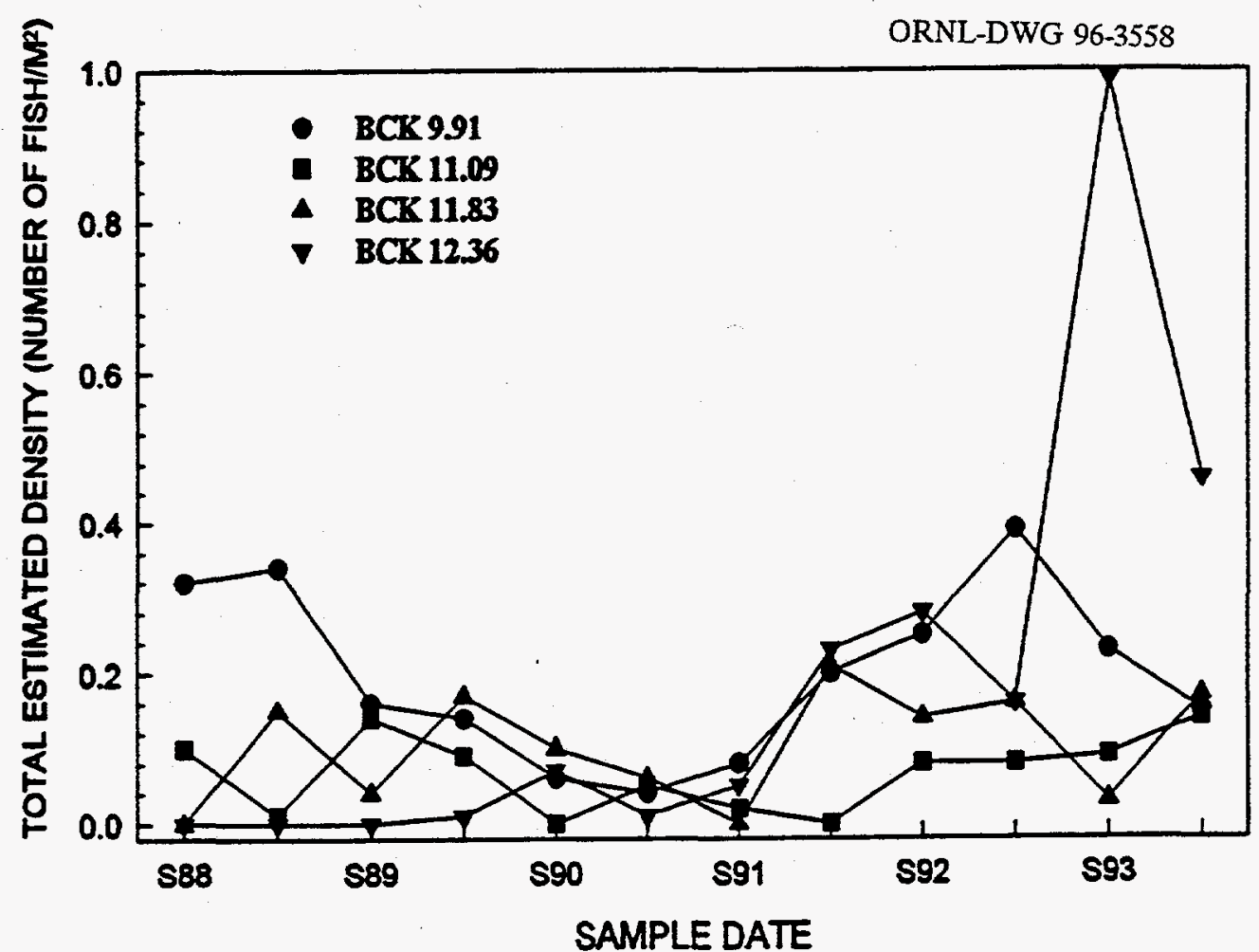

Fig. 5.10. Total estimated Tennessee dace density (number of fish $/ \mathrm{m}^{2}$ ) in Bear Creek (BCK), spring 1988-fall 1993. BCK = Bear Creek kilometer. 
density value. The loss of habitat may account for the decline of the Tennessee dace at this site. Some of the deeper pools along undercut banks and tree roots have filled in with sediments over the last 5 years. These are areas that Tennessee dace frequently inhabit and where they seek shelter when disturbed. Densities of the other dominant fish species (central stoneroller, blacknose dace, and creek chub) increased after spring 1988.

Total estimates of density and biomass of the fish community at BCK 9.40 appear stable throughout the 6 years of sampling when comparing either the spring or the fall sampling periods. This site does exhibit increased values of density and biomass from spring to fall.

The Tennessee dace also exhibited a decline in density at BCK 9.40 from spring 1988 through fall 1990 (Fig. 5.9), but the decline was not as great as at BCK 7.87. Tennessee dace densities increased from spring 1991 through fall 1992. Depressed density values in spring 1993 may simply be the normal cyclic pattern of lower densities in the spring and higher densities in the fall, as the fall 1993 density was higher. Continued sampling will help determine the status of the Tennessee dace population at BCK 9.40.

Estimated total fish density at BCK 9.91 remained relatively stable from spring 1988 through spring 1991 (Fig. 5.4). Densities increased in fall 1992 through fall 1993 and were greater than previous years (Southworth et al. 1992). Biomass did not increase as density did in fall 1992 through fall 1993, compared with earlier years.

There are areas within the stream at BCK 9.91 that have changed over the last six years, but they do not appear to have had an overall negative effect on the fish community. Some pools and shallow areas have filled with construction type gravel. This gravel may be the result of remedial actions at NT-7 and road repair upstream of BCK 9.91.

A similar pattern in total estimated density of Tennessee dace was observed between BCK 9.91 and 9.40 (Fig. 5.9). There was a decrease in density from fall 1989 through fall 1990. Tennessee dace increased from spring 1991 through fall 1992 followed by a decline in density in 1993. Density values in spring 1991 through spring 1993 were similar to previous years (Southworth et al. 1992).

Total estimated fish density and biomass of the fish community, including the Tennessee dace at BCK 11.09, do not appear stable for more than 2 years at a given time (Figs. 5.4, 5.7, and 5.9). This may be due to the nature of the stream at this site, in that there are periods when the entire stream is dry or may contain isolated pools. Total estimated fish density and biomass values have fluctuated from spring 1988 through fall 1993 but are within the ranges observed from spring 1984 through fall 1987 (Southworth et al. 1992).

Total estimated fish density and biomass have exinibited the greatest change at BCK 12.36 during the 6 years of sampling (Figs. 5.4 and 5.7). Total estimated fish density and biomass have increased from 0.01 individuals $/ \mathrm{m}^{2}$ and $0.02 \mathrm{~g} / \mathrm{m}^{2}$ in spring 1988 to a peak of 4.95 individuals $/ \mathrm{m}^{2}$ and $14.43 \mathrm{~g} / \mathrm{m}^{2}$ in spring 1993. Tennessee dace density increased from 0.0 individuals $/ \mathrm{m}^{2}$ in spring 1988 to 0.99 individuals $/ \mathrm{m}^{2}$ in spring 1993. The fish community at BCK 12.36 appears to be recovering from past pollutants at this site following the closure of the S-3 Ponds in 1988. The fish population may continue to improve before stabilizing at this site.

Total estimated density and biomass values for sites in Bear Creek were not dissimilar to those observed in the reference streams with the exception of the lack of fish at BCK 12.36 in 1988. 


\subsubsection{Annual production}

Annual production was calculated from spring 1988 to spring 1993 . Total production and production for selected species is given in Table 5.4. Total productivity was highest at BCK 7.87 in three out of the five time periods. BCK 11.09 and 12.36 were each highest in total production for one time period. Total production in Bear Creek ( 0.04 to 9.14) was generally higher than was found in the reference streams $(-0.09$ to $4.40 \mathrm{~g}$ wet $\mathrm{wt} \cdot \mathrm{m}^{-2}$ year $\left.{ }^{-1}\right)$. Production in Bear Creek was similar to production values in other ORR streams (Table 5.5).

Production increased during the 1988-89 period from 12.36 downstream to BCK 7.87 with the exception at BCK 9.40. This downstream increase in production was not present during the other years.

Total production increased at BCK 12.36 throughout the sampling periods. This corresponds to the increase in densities and biomass at this site. Total production at the other sites varied from year to year.

Individual species production was dominated at most Bear Creek sites by the most common species, central stoneroller, blacknose dace, and creek chub. Individual species production in the reference streams was dominated by blackirose dace and creek chub.

\subsubsection{Conclusions and Recommendations}

In general, the data indicate that Bear Creek sites above the weir at BCK 4.55 had a limited fish fauna (low species richness) compared with Mill Branch, yet were high in density and biomass. The ability for fish species to recolonize sites in Bear Creek is limited by the weir at BCK 4.55 which appears to be a barrier to fish migration upstream. There were no changes in fish species composition in Bear Creek upstream of the weir, but the frequency of occurrence of fish sampled at some sites did increase.

One important aspect of the fish fauna of Bear Creek above the weir is the distribution and abundance of the Tennessee dace. The Tennessee dace is listed as a species "deemed in need of management" by the Tennessee Wildlife Resources Agency and its habitat is protected (Starnes and Etnier 1980). Consideration for the Tennessee dace and protection of its habitat must continue as a part of planning and carrying out remedial actions. This will help to ensure that populations of Tennessee dace are protected on ORR.

Improvements in the fish populations were observed at the two uppermost sites in Bear Creek. Significant changes occurred in fish population density, biomass, and total production at BCK 12.36 from 1988 through 1993. Significant impacts on the fish population were evident in previous years (Southworth et al. 1992) and in 1988 at BCK 12.36. Impacts appear to be related to the proximity of the S-3 Ponds because of poor water quality. Beginning in spring 1989 , the fish fauna increased in species present, density, and biomass at BCK 12.36. Values for density, biomass, and total production were lower at BCK 11.83 in 1988 than in following years. This site may also have been adversely affected by the S-3 Ponds.

Decreases in density and biomass at sites in Bear Creek may be due to construction activity in Bear Creek Valley. Gravel and fine sediments have accumulated at both BCK 9.91 and 7.78. Excessive siltation reduces substrate heterogeneity, increases turbidity, limits plant growth, alters invertebrate communities, and increases fish egg and larval mortality; thereby limiting fish 
Table 5.4. Annual production rates in Bear Creek and in two reference streams, Grassy Creek and Mill Branch, for spring 1988 through 1993 Measurements in grams wet wt $\mathrm{m}^{-2}$ year ${ }^{-1} \mathrm{SE}^{a}$

\begin{tabular}{|c|c|c|c|c|c|c|c|c|c|c|c|}
\hline \multirow[b]{2}{*}{ Species } & \multirow{2}{*}{$\begin{array}{l}\text { Production } \\
\text { period }\end{array}$} & \multicolumn{10}{|c|}{ Sites $^{b}$} \\
\hline & & BCK 0.7 & BCK 3.25 & BCK 7.87 & BCK 9.40 & BCK 9.91 & BCK 11.09 & BCK 11.83 & BCK 12.36 & GCK 2.4 & MBK 1.6 \\
\hline \multirow[t]{5}{*}{ Central stoneroller } & $1988-89$ & & 1.56 & $1.53 \pm 0.08$ & $0.86 \pm 0.08$ & $1.35 \pm 0.09$ & 1.54 & -0.01 & $0.00 \pm 0.00$ & & 0.00 \\
\hline & $1989-90$ & & $0.33 \pm 0.07$ & $1.76 \pm 0.09$ & 1.10 & 2.62 & 3.32 & -0.28 & $-0.02 \pm 0.00$ & & $-0.04 \pm 0.00$ \\
\hline & $1990-91$ & & $0.44 \pm 0.07$ & $0.75 \pm 0.07$ & 1.74 & 3.64 & $5.11 \pm 0.16$ & $0.42 \pm 0.28$ & $0.27 \pm 0.02$ & & 0.00 \\
\hline & $1991-92$ & & $2.98 \pm 0.13$ & 2.22 & 1.84 & 3.42 & $2.36 \pm 0.18$ & -0.03 & $1.13 \pm 0.05$ & & -0.09 \\
\hline & $1992-93$ & 0.71 & $2.01 \pm 0.12$ & 2.71 & 0.98 & $2.79 \pm 0.14$ & $1.63 \pm 0.16$ & -0.02 & $2.22 \pm 0.20$ & & $-0.02 \pm 0.01$ \\
\hline \multirow[t]{5}{*}{ Striped shiner } & $1988-89$ & & $0.69 \pm 0.04$ & $0.00 \pm 0.00$ & -0.01 & -0.07 & $0.00 \pm 0.00$ & & & -0.02 & 0.00 \\
\hline & $1989-90$ & & $0.60 \pm 0.04$ & $0.00 \div 0.00$ & 0.01 & 0.26 & $-0.01 \pm 0.00$ & & & -0.21 & $0.00 \pm 0.00$ \\
\hline & 1990-91 & & $0.51 \pm 0.04$ & 0.13 & $-0.17 \pm 0.02$ & 0.17 & $-0.01 \pm 0.00$ & & & $-0.09 \pm 0.01$ & $-0.04 \pm 0.01$ \\
\hline & $1991-92$ & & 0.47 & 0.20 & $-0.08 \pm 0.01$ & -0.01 & $0.00 \pm 0.00$ & & & $0.00 \pm 0.00$ & $-0.02 \pm 0.00$ \\
\hline & $1992-93$ & 2.56 & 0.72 & -0.01 & 0.00 & 0.00 & $0.00 \pm 0.00$ & & & & 0.00 \\
\hline \multirow[t]{5}{*}{ Tennessee dace } & $1988-89$ & & 0.00 & 0.47 & 0.06 & $0.28 \pm 0.03$ & -0.19 & $-0.03+0.01$ & $0.00 \pm 0.00$ & & $0.01 \pm 0.00$ \\
\hline & $1989-90$ & & $0.00 \pm 0.00$ & $0.04 \pm 0.02$ & 0.01 & 0.10 & -0.08 & -0.11 & $-0.03+0.00$ & & $0.00 \pm 0.00$ \\
\hline & $1990-91$ & & $0.00 \pm 0.00$ & $0.35 \pm 0.02$ & $-0.05 \pm 0.01$ & 0.06 & $-0.01 \pm 0.00$ & $-0.03+0.01$ & $-0.02 \pm 0.00$ & & $0.00 \pm 0.00$ \\
\hline & $1991-92$ & & $-0.00 \pm 0.00$ & $0.28 * 0.03$ & -0.02 & $-0.05 \pm 0.00$ & $0.02 \pm 0.01$ & $0.00 \pm 0.00$ & $0.09 \pm 0.01$ & & 0.00 \\
\hline & 1992-93 & & $0.00 \pm 0.00$ & $0.05 \pm 0.01$ & 0.01 & -0.04 & $0.01 \pm 0.01$ & -0.02 & $0.85 \pm 0.03$ & & -0.00 \\
\hline \multirow[t]{5}{*}{ Blacknose dace } & $1988-89$ & & 0.70 & 3.13 & 1.89 & $1.16 \pm 0.06$ & 1.20 & 1.04 & 0.04 & $-0.05 \pm 0.04$ & 1.85 \\
\hline & $1989-90$ & & $0.40 \pm 0.02$ & 2.88 & 1.69 & $2.23 \pm 0.32$ & 2.54 & $3.32 \pm 0.29$ & 1.81 & $0.35 \pm 0.07$ & 1.77 \\
\hline & 1990-91 & & 0.52 & 2.04 & $2.28 \pm 0.07$ & $2.30 \pm 0.31$ & $2.97 \pm 0.10$ & 3.68 & $2.75 \pm 0.08$ & $0.48 \pm 0.07$ & 1.60 \\
\hline & $1991-92$ & & 0.95 & $2.86 \pm 0.09$ & $2.57 \pm 0.05$ & 2.21 & $1.75 \pm 0.09$ & 2.64 & 2.07 & 0.28 & 1.30 \\
\hline & $1992-93$ & 0.80 & $0.93 \pm 0.05$ & $3.82 \star 0.32$ & $2.92 \pm 0.04$ & 2.79 & $1.07 \pm 0.06$ & $3.67 \pm 0.10$ & 2.80 & & $0.82 \pm 0.03$ \\
\hline
\end{tabular}


Table 5.4 (continued)

\begin{tabular}{|c|c|c|c|c|c|c|c|c|c|c|c|}
\hline \multirow[b]{2}{*}{ Species } & \multirow{2}{*}{$\begin{array}{c}\text { Production } \\
\text { period }\end{array}$} & \multicolumn{10}{|c|}{ Sites $^{b}$} \\
\hline & & BCK 0.7 & BCK 3.25 & BCK 7.87 & BCK 9.40 & BCK 9.91 & BCK 11.09 & BCK 11.83 & BCK 12.36 & GCK 2.4 & MBK 1.6 \\
\hline \multirow[t]{5}{*}{ Creek chub } & $1988-89$ & & .0 .03 & 2.66 & $0.24 \pm 0.02$ & 1.09 & 0.09 & 0.30 & $0.00 \pm 0.00$ & 0.01 & 0.28 \\
\hline & $1989-90$ & & -0.01 & 2.60 & 0.28 & 0.39 & 0.17 & 0.67 & $0.07 \pm 0.02$ & 0.34 & $0.07 \pm 0.01$ \\
\hline & $1990-91$ & & 0.00 & $1.25 \pm 0.10$ & -0.05 & $0.12 \pm 0.08$ & 0.32 & -0.14 & $0.75 \pm 0.06$ & 0.62 & $0.04 \pm 0.01$ \\
\hline & $1991-92$ & & $0.03 \pm 0.01$ & 1.36 & $0.03 \pm 0.01$ & 0.69 & 0.19 & $0.07 \pm 0.02$ & $1.53 \pm 0.09$ & 0.47 & $0.26 \pm 0.05$ \\
\hline & $1992-93$ & $0.00 \pm 0.00$ & -0.01 & 1.59 & $0.14+0.01$ & 1.43 & 0.52 & $0.40 \pm 0.12$ & 3.27 & & 0.67 \\
\hline \multirow[t]{5}{*}{ White sucker } & $1988-89$ & & $0.00 \pm 0.00$ & 0.02 & $0.00 \pm 0.00$ & -0.01 & & & & -0.03 & \\
\hline & $1989-90$ & & $0.00 \pm 0.00$ & $0.00 \pm 0.00$ & $0.00 \pm 0.00$ & $0.02 \pm 0.01$ & & & & -0.01 & \\
\hline & $1990-91$ & & 0.00 & -0.01 & $-0.01 \pm 0.00$ & $0.03 \pm 0.01$ & & & & -0.02 & \\
\hline & $1991-92$ & & 0.00 & -0.01 & $-0.01 \pm 0.00$ & $-0.01 \pm 0.01$ & & & & -0.03 & \\
\hline & $1992-93$ & & $0.00 \pm 0.00$ & -0.03 & $0.00 \pm 0.00$ & $0.03 \pm 0.01$ & & & & & \\
\hline \multirow[t]{5}{*}{ Banded sculpin } & $1988-89$ & & 0.00 & $0.00 \pm 0.00$ & 0.02 & $0.00 \pm 0.00$ & & & & $0.00 \pm 0.00$ & \\
\hline & $1989-90$ & & $0.00 \pm 0.00$ & $0.00 \pm 0.00$ & $-0.02 \pm 0.01$ & $0.00 \pm 0.00$ & & & & $-0.11+0.07$ & \\
\hline & $1990-91$ & & $-0.02 \pm 0.00$ & $0.00 \pm 0.00$ & $0.09 \pm 0.01$ & $0.00 \pm 0.00$ & & & & $-0.16 \pm 0.03$ & \\
\hline & $1991-92$ & & $-0.02 \pm 0.00$ & -0.02 & $0.41 \pm 0.04$ & -0.01 & & & & $.0 .05 \pm 0.02$ & \\
\hline & $1992-93$ & $0.40 \pm 0.05$ & $-0.01 \pm 0.00$ & -0.02 & $0.22 \pm 0.02$ & -0.01 & & & & & \\
\hline \multirow[t]{5}{*}{ Stripetail darter } & $1988-89$ & & $0.10 \pm 0.02$ & & & & & & & & $-0.06+0.01$ \\
\hline & $1989-90$ & & $0.08+0.02$ & & & & & & & & $0.01+0.01$ \\
\hline & $1990-91$ & & $0.06 \pm 0.01$ & & & & & & & & $0.05 \pm 0.01$ \\
\hline & $1991-92$ & & $0.07 \pm 0.02$ & & & & & & & & $0.06 \pm 0.01$ \\
\hline & $1992-93$ & $0.01 \pm 0.02$ & 0.11 & & & & & & & & $0.05 \pm 0.01$ \\
\hline
\end{tabular}


Table 5.4 (continued)

\begin{tabular}{|c|c|c|c|c|c|c|c|c|c|c|c|}
\hline \multirow[b]{2}{*}{ Species } & \multirow{2}{*}{$\begin{array}{c}\text { Production } \\
\text { period }\end{array}$} & \multicolumn{10}{|c|}{ Sites $^{b}$} \\
\hline & & BCK 0.7 & BCK 3.25 & BCK 7.87 & BCK 9.40 & BCK 9.91 & BCK 11.09 & BCK 11.83 & BCK 12.36 & GCK 2.4 & MBK 1.6 \\
\hline \multirow[t]{5}{*}{ Snubnose darter } & $1988-89$ & & $0.04 \pm 0.02$ & & & & & & & & $0.04 \pm 0.02$ \\
\hline & $1989-90$ & & $0.01 \pm 0.02$ & & & & & & & & $-0.03 \pm 0.01$ \\
\hline & 1990-91 & & -0.02 & & & & & & & & $-0.01 \pm 0.01$ \\
\hline & $1991-92$ & & 0.01 & & & & & & & & $-0.03 \pm 0.01$ \\
\hline & $1992-93$ & $-0.04 \pm 0.00$ & $0.00 \pm 0.02$ & & & & & & & & -0.05 \\
\hline \multirow[t]{5}{*}{ Total $^{c}$} & $1988-89$ & & 2.99 & 7.80 & 3.06 & 3.77 & 2.64 & 1.30 & 0.04 & -0.09 & 1.98 \\
\hline & $1989-90$ & & 1.35 & 7.29 & 3.07 & 5.57 & 5.93 & 3.60 & 1.83 & 0.37 & 1.78 \\
\hline & $1990-91$ & & 1.26 & 4.51 & 3.83 & 6.31 & 8.37 & 3.93 & 3.75 & 0.82 & 1.50 \\
\hline & $1991-92$ & & 4.37 & 6.80 & 4.75 & 6.24 & 4.31 & 2.68 & 4.83 & 0.67 & 1.35 \\
\hline & $1992-93$ & 4.71 & 3.62 & 8.10 & 4.27 & 6.99 & 3.24 & 4.03 & 9.14 & & $4.40^{\circ}$ \\
\hline
\end{tabular}

${ }^{a}$ Standard error could not be calculated for all means because some size classes had only one fish per class.

${ }^{b} \mathrm{BCK}=$ Bear Creek kilometer, GCK = Grassy Creek kilometer, and MBK = Mill Branch kilometer.

'Totals include niscellaneous species (spotfin shiner, rosefin shiner, bluntnose minnow, northern hogsucker, rock bass, redbreast sunfish, warmouth, bluegill, black darter, and logperch) not listed in the table. 
Table 5.5. Annual production rates of fish communities in warmwater streams in the southeastern United States

Measurements in grams wet wt per square meter per year

\begin{tabular}{|c|c|c|c|c|}
\hline Stream/State & $\begin{array}{l}\text { Stream } \\
\text { order }\end{array}$ & $\begin{array}{l}\text { Sample } \\
\text { year }\end{array}$ & Production & Reference \\
\hline $\begin{array}{l}\text { J. Carpenter Branch, } \\
\text { Kentucky }\end{array}$ & $1 \mathrm{st}$ & $1967-68$ & 8.55 & Lotrich 1973 \\
\hline \multirow{2}{*}{$\begin{array}{l}\text { Clemmons Creek, } \\
\text { Kentucky }\end{array}$} & 2nd & $1967-68$ & 10.55 & \\
\hline & $3 r d$ & & 7.72 & \\
\hline \multirow[t]{3}{*}{ Guys Run. Virginia } & 2nd & $1979-80$ & 2.84 & Neves and Pardue 1983 \\
\hline & 2nd & & 3.16 & \\
\hline & 2nd & & 3.96 & \\
\hline \multirow{5}{*}{$\begin{array}{l}\text { Mitchell Branch, } \\
\text { Tennessee }\end{array}$} & $2 \mathrm{nd}^{a}$ & $1987-88$ & 3.06 & Ryon 1994 \\
\hline & $2 n d^{a}$ & $1988-89$ & 4.73 & \\
\hline & $2 \mathrm{nd}^{a}$ & $1989-90$ & 6.85 & \\
\hline & $2 \mathrm{nd}^{a}$ & $1991-92$ & 3.91 & Schilling 1995 \\
\hline & $2 \mathrm{nd}^{a}$ & $1992-93$ & 6.37 & \\
\hline \multirow{4}{*}{$\begin{array}{l}\text { White Oak Creek, } \\
\text { Tennessee }\end{array}$} & 2nd & $1992-93$ & 4.33 & Schilling 1994 \\
\hline & $2 \mathrm{nd}^{a}$ & & 17.11 & \\
\hline & $3 \mathrm{rd}^{2}$ & & 12.78 & \\
\hline & $4 \mathrm{th}^{a}$ & & 3.65 & \\
\hline \multirow[t]{2}{*}{ Fifth Creek, Tennessee } & 1 st & $1992-93$ & 27.12 & \\
\hline & $1 s t^{a}$ & & 4.01 & \\
\hline \multirow{2}{*}{$\begin{array}{l}\text { Melton Branch, } \\
\text { Tennessee }\end{array}$} & 2 nd & $1992-93$ & 2.02 & \\
\hline & $3 \mathrm{rd}^{a}$ & & 6.93 & \\
\hline
\end{tabular}

aSample site is associated with industrial effluent.

Note: For full references, see Sect. 6.

survival and availability of food, cover, and spawning habitat (Ellis 1936; Chutter 1969; Gammon 1970; Hynes 1970, 1974; Sorensen et al. 1977; Muncy et al. 1979; Berkman and Rabeni 1987).

\subsubsection{Future Studies}

Routine, quantitative monitoring of fish density, biomass, richness, and population size structure will be conducted 
twice annually (spring and fall) at the seven sites in Bear Creek and at the three reference sites in an effort to determine whether the system is continuing to recover and to assess effects that remedial action may have on the fish populations. Major remedial actions have been proposed in the Bear Creek Valley. Some of these, such as withdrawing groundwater from a contaminated plume and discharging it, after treatment, to upper EFPC, could have detrimental effects on the fish populations in Bear Creek. Fluctuations in flow and/or drying of streambed portions can reduce available habitat and fish spawning success, and severely alter stream thermal and chemical regimes (Hynes 1970, 1974; Burkhead and Jenkins 1991).

Studies to determine the life history and present distribution of the Tennessee dace will continue in an effort to protect the species on ORR and also allow for other uses of the land adjoining streams in which the dace occurs. Further study of the Tennessee dace may extend beyond the scope of this project and may require an extensive study to determine interactions between this species and other species in an effort to determine what impact the weir at BCK 4.55 may have on the Tennessee dace and other fish species. Another study that may require extensive research is to determine if beaver dams such as the one in Bear Creek downstream of the Haul Road havc an impact on the Tennessee dace or other fish populations.

\subsection{BENTHIC MACROINVERTEBRATES (G. F. Cada, J. G. Smith, and M. R. Smith)}

\subsubsection{Introduction}

Previous results from the benthic macroinvertebrate community studies (June 1984-July 1987) provided strong evidence of degraded conditions in Bear Creek (Southworth et al. 1992). A spatial gradient in the extent of impact was exhibited by the invertebrate community in Bear Creek. Density, taxonomic richness, and the number and abundance of pollution-sensitive taxa exhibited significant increases with distance from the $\mathrm{Y}-12$ Plant. The invertebrate community had apparently fully recovered from upstream perturbations within a reach located approximately $3.25-\mathrm{km}$ (BCK 3.25 ) upstream of the stream's confluence with EFPC. The greatest change in the macroinvertebrate community appeared to occur downstream of the SS-5 spring, suggesting that the spring positively affected the invertebrate community.

Benthic macroinvertebrate community studies continued after July 1987 with the primary objective of assessing temporal changes in order to help evaluate the effectiveness of remedial actions in Bear Creek Valley. Additionally, spatial evaluations continued in order to provide further information on the ecological condition of Bear Creek and to help identify the type and origin of any factors which may be contributing or leading to any observed degraded conditions. This report includes the results of 9 years of benthic macroinvertebrate collections from April sampling periods (1985-93), including a combination of 3 years of data previously presented (1985-87) along with 6 years of data not yet presented (1988-93). The inclusion of previously reported data improves evaluation of both temporal and spatial trends, because having more data allows natural variability to be more accurately defined and distinguished from unusual changes or differences.

Future reports will include the results from the fall sampling season (i.e., October), while samples collected during the winter and summer periods will be archived unless further resolution of results are needed in the future. Also included in this report is 
an analysis of the benthic

macroinvertebrate community of lower

Bear Creek (i.e., BCK 0.70) to evaluate whether the ORNL White Wing Scrap Yard (Waste Area Group 11) may be a potential source of impact to Bear Creek. The results of this analysis are reported in Appendix F.

\subsubsection{Materials and Methods}

Following the initial year of the Bear Creek monitoring program (May 1984-April 1985), the sampling frequency was reduced from approximately monthly to quarterly (Southworth et al. 1992). Additionally, the number of collection sites on Bear Creek was reduced from 9 to 7 and the number of reference sites was reduced from 14 to 13 . In the third year of the monitoring program, the number of sites sampled on Bear Creek remained 7 (Fig. 5.11), while the number of reference sites was reduced to 10 . After the third year, seven sites continucd to be sampled on Bear Creek, but the number of reference sites was reduced to five (Southworth et al. 1992). The reference sites sampled after the third year (i.e., after April 1987) were located on or adjacent to ORR and included two sites on Gum Hollow Branch and one site each on Grassy Creek, Mill Branch, and University of Tennessee Farm Creek (Fig. 5.12).

The reference sites selected represented the ranges in size similar to those that existed among the Bear Creek sites. Grassy Creek was selected to serve primarily as a reference site for BCK 12.36 , 11.83, and 11.09; upper Gum Hollow Creek (GHK 2.9) and U. T. Farm Creek (UTK 0.6) were selected as reference sites for BCK 9.40, 9.91, 11.09, 11.83, and 12.36; and Mill Branch (MBK 1.6) and lower Gum Hollow Creek (GHK 1.6) were selected primarily as reference sites for BCK 3.25, 7.87, and 9.40. However, a statistical evaluation of the reference sites using the same response variables as those used to evaluate the Bear Creek sites (see below), suggested that no major differences existed among the reference sites that could be attributed to size. Thus, all reference sites were used for all Bear Creek sites. The results of the statistical evaluation are reported in Appendix G.

From 1988 through 1990, five replicate samples were collected from each site during each sampling period. Following the April 1990 sampling period, the number of replicates was reduced to three (Appendix C). Only three of the five replicates collected from 1988 through 1990 were processed; the three samples processed were selected randomly with a random number table. All benthic macroinvertebrate samples were collected from a riffle at each site with a Surber stream bottom sampler $\left(0.09 \mathrm{~m}^{2}\right.$ or $1 \mathrm{ft}^{2}$; $363-\mu \mathrm{m}$-mesh net). Samples were placed into pre-labeled, polyurethane-coated, glass jars and preserved in $80 \%$ ethanol; the ethanol was replaced with fresh ethanol within 1 week. Additional details of the field and associated quality assurance (QA) procedures followed in the collection and maintenance of these samples are given in Smith (1992).

Supplemental information on water quality and physical characteristics of each site was recorded at the time of sampling. Water temperature, specific conductance, $\mathrm{pH}$, and dissolved oxygen were measured with a Horiba Model U-7 Water Quality Checker. Water depth, location within the riffle area (distance from permanent headstakes on the stream bank), visual estimate of the relative current velocity (very slow, slow, moderate, or fast), and substrate type (visual estimation), based on a modified Wentworth particle size scale (Loar et al. 1985), were recorded for each sample. All measurements/estimates for water quality and physical characteristics 




Fig. 5.11. Location of benthic macroinvertebrate community study sampling sites. WT $=$ west tributary, ET $=$ east tributary, $\mathrm{ST}=$ south tributary, NT = north tributary, SS = south spring, NS = North spring. 


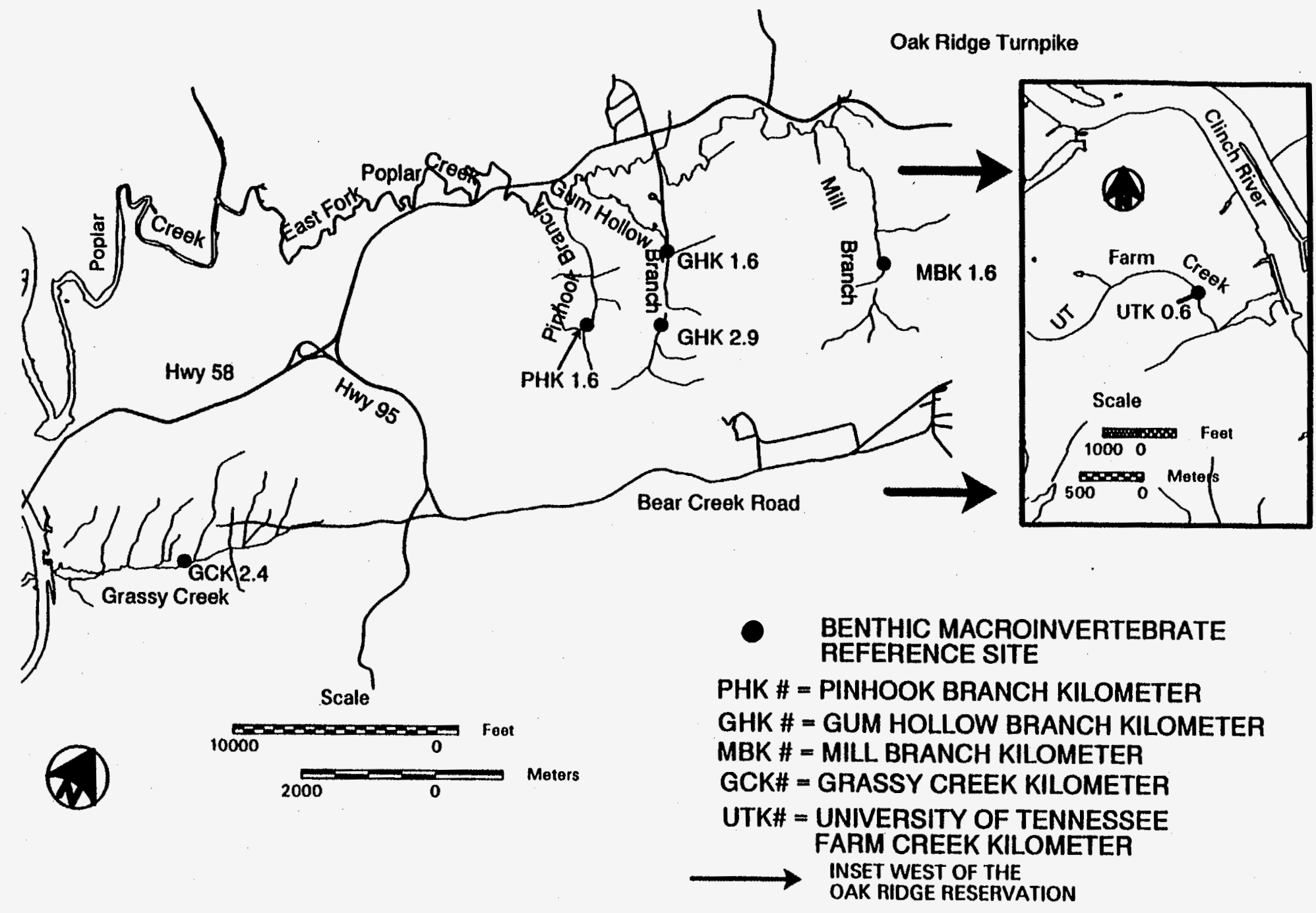

Fig. 5.12. Location of reference sites for the benthic macroinvertebrate community task. 
were obtained in accordance to established QA procedures (Smith 1992). The supplemental information was used only if needed for observational support.

Processing of benthos samples collected prior to April 1, 1988, was conducted by TVA personnel in their Muscle Shoals, Alabama, laboratory. Due to a reduction-in-force at TVA, all samples collected after April 1, 1987, have been processed by personnel of JAYCOR in a laboratory located at ORNL. The procedures followed by TVA personnel have been previously described (Southworth et al. 1992). The procedures followed by JAYCOR personnel were similar to those followed by TVA, but several modifications were made.

In a laboratory, JAYCOR first washed each sample after placing it into a U.S. Standard No. 60-mesh (250- $\mu \mathrm{m}$-mesh) sieve. Small aliquots of the sample (vs whole samples by TVA) were removed from the sieve, placed into a white tray containing water, and then the organisms were removed from the sample debris with forceps. This was repeated until the entire sample was sorted. Finally, the removed organisms were identified to the lowest practical taxon and enunierated. Further details of the laboratory procedures that were followed by JAYCOR for processing benthos samples may be found in Wojtowicz and Smith (1992).

Data were managed and analyzed on computer primarily with SAS software and procedures (SAS 1985a and 1985b).

Statistical analyses included both descriptive and parametric statistical techniques. Because two separate laboratories processed samples during the 9-year study period, only the data obtained after 1987 (i.e., 6 years) were utilized in the parametric statistical analyses. The low and highly variable sorting efficiency of the TVA laboratory (J.G. Smith, ESD/ORNL, unpublished data) made evaluating the combined data sets (i.e., TVA and
JAYCOR) with parametric statistics difficult. In future reports, appropriate ways of analyzing the combined data sets from both laboratories will be identified and utilized. Because standardization of the data obtained from both processing laboratories required some minor (e.g., dropping low density not truly benthic organisms such as Hemiptera) and major (e.g., changing generic level identifications of the Chironomidae to subfamily and tribe) modifications to the data obtained from TVA, descriptive statistics have been recalculated for data from 1985 to 1987 . Parametric procedures included ANOVA models on three responses: density (total number of organisms per $0.1 \mathrm{~m}^{2}$ ), total richness (total number of taxa per sample), and the total combined number of the Ephemeroptera, Plecoptera, and Trichoptera taxa (total number of EPT taxa per sample or EPT richness). Prior to performing the ANOVAs, observed values for each response were transformed [i.e., $\log _{10}(X+1)$ for density values, and square root of $X$ for total and EPT richness values, where $X=$ the individual observed values for density, taxonomic richness, and EPT richness; Elliott 1977].

ANOVA models were used for two approaches to help evaluate temporal changes, at sites previously identified as impacted (Southworth et al. 1992), for evidence of improvements or further degradation. For each approach, a $p \leq 0.05$ was considered statistically significant. The first approach was a twoway ANOVA on each response variable, with site (fixed variable) and sampling year (fixed variable) the main effects. A significant interaction between site and sampling year indicated that the patterns of change in a response variable between two or more sites from year to year were different and, thus, may be indicative of changes associated with remedial actions. An insignificant $(p>0.05)$ interaction indicated that any year to year changes 
occurring in the benthic community at the Bear Creek sites were not great enough to be statistically distinguished from those changes occurring at the reference sites, thus suggesting that remedial actions had no statistically detectable effects.

For the second approach, a simple linear regression was used to estimate sitespecific linear trends for each response over the study period. For this approach, the slopes of the regression lines for all sites over the study period (i.e., 6-year period after April 1987) were compared for parallelism with an ANOVA. This allowed the data for the potentially impacted sites to be evaluated, relative to the reference sites, with respect to linear trends over the study period that may have been indicative of persistent improvement (i.e., general increase in values through time) or degradation (i.e., general decrease in values through time).

\subsubsection{Results}

\subsubsection{Taxonomic composition}

A checklist of benthic macroinvertebrate taxa collected from each site on Bear Creek during April collections from 1985 to 1993 is presented in Appendix D, Table D.1. Macroinvertebrate taxa collected during the same period at the five reference sites are presented in Appendix E, Table E.i. Although most major macroinvertebrate groups common to lotic environments were present at all reference sites and in Bear Creek, taxonomic distribution in the latter exhibited considerable spatial and temporal variation. Only five taxa, Oligochaeta (aquatic worms), the dipteran (true flies) taxa Orthocladiinae, Tanypodinae, and Ceratopogonidae, and the plecopteran, Amphinemura, were present at all Bear Creek sites over the majority of the study period. Ephemeroptera (mayflies) taxa displayed a distinct spatial trend with distance downstream from the Y-12 Plant. Although no mayflies were collected at BCK 12.36 throughout the study period, the number of ephemeropteran taxa generally increased with distance downstream, with the downstream most site (BCK 3.25) having comparable numbers of taxa with the reference sites. Other taxa, including Turbellaria (flatworms), Plecoptera (stoneflies), and Trichoptera (caddisflies) exhibited both spatial and temporal trends in Bear Creek. Prior to the sixth sampling year (1990), Turbellaria were only collected downstream of BCK 9.91, but in each of the subsequent sampling years they were found at both BCK 9.91 and 11.09. Although the Plecoptera genus Amphinemura was present at all sites over most of the study, the majority of stonefly taxa were either absent or have cnly been present at BCK 12.36 since 1990 . The coleopterans within the family Elmidae (riffle beetles) were represented at all Bear Creek sites up to BCK 11.83 throughout the study period, but no taxa were collected at BCK 12.36 until the fourth year of the study (1988). In contrast, the Coleoptera taxa in the family Psephenidae (water pennies) were consistently present only at the lowest site (BCK 3.25) in Bear Creek.

\subsubsection{Abundance}

Total density. Figure 5.13 displays the mean benthic macroinvertebrate densities measured in April of each year at each Bear Creek and reference site from 1985 to 1993 . Densities were lowest at nearly all sites in 1985 and generally increased with time until 1992. Total densities decreased at most sites between April 1992 and April 1993, but were comparable to recent years prior to 1992 .

Relative increases in density with time were very high at some Bear Creek sites. 

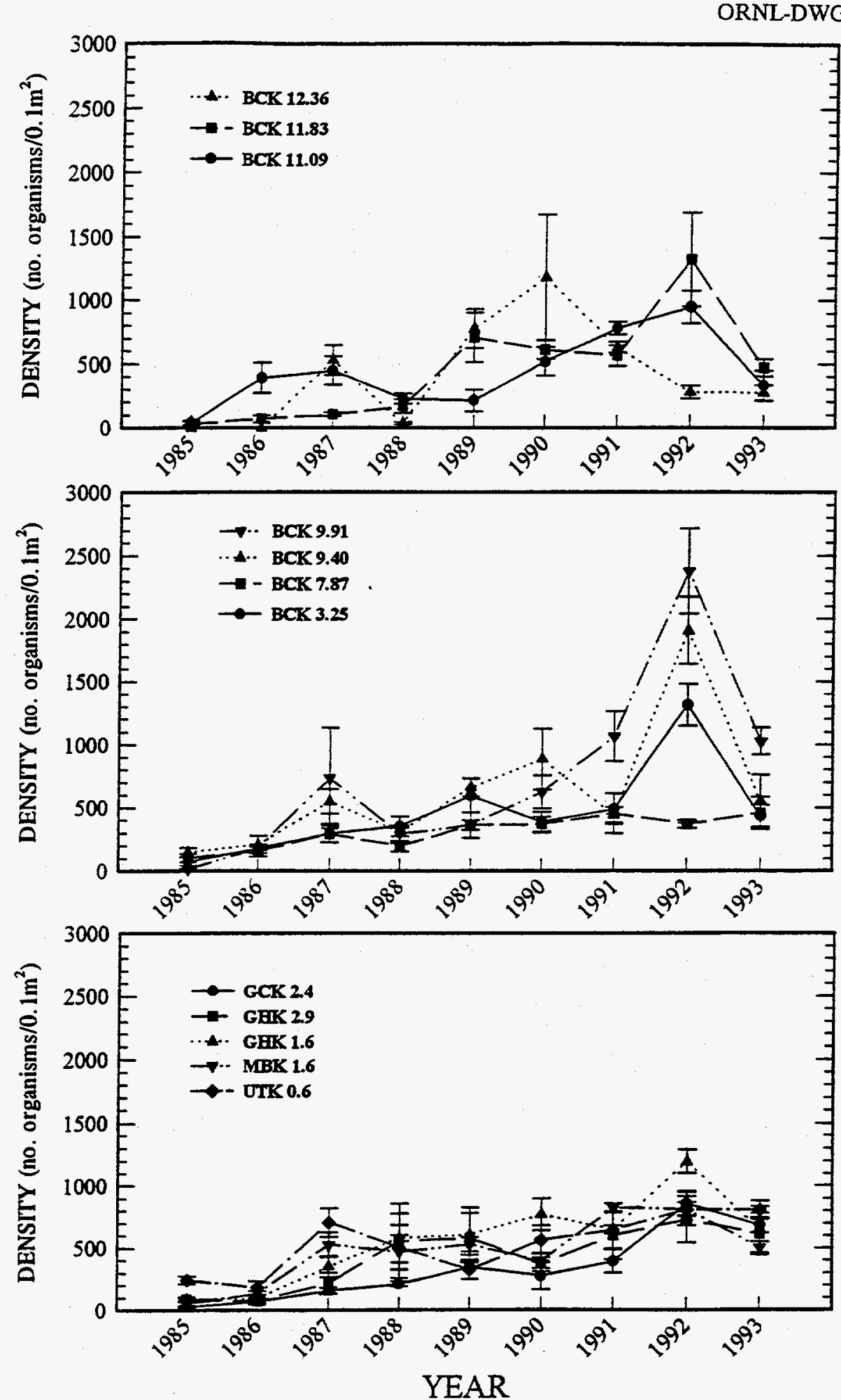

Fig. 5.13. Mean total community densities of the benthic macroinvertebrate at sites in Bear Creek, Grassy Creek, Gum Hollow Branch, Mill Branch, and U.T. Farm Creek in April of each year, 1985-93. Vertical bars represent \pm 1 SE. GCK = Grassy Creek kilometer; GHK = Gum Hollow kilometer; MBK = Mill Branch kilometer; UTK = U.T. Farm Creek kilometer. 
For example, estimated mean densities of benthic macroinvertebrates at BCK 9.91 increased over 150-fold between 1985 and 1992 (15 vs 2378 organisms per $0.1 \mathrm{~m}^{2}$; Fig. 5.13). Similarly, mean densities at the uppermost site, BCK 12.36 , increased from 2 to 280 organisms per $0.1 \mathrm{~m}^{2}$ between 1985 and 1992, a 140-fold change. Averaged among all Bear Creek sampling sites, benthos densities were 54 times higher in 1992 than they were in 1985. Greatest increases occurred at BCK 9.91 and 12.36, whereas smallest increases were observed at BCK 7.87 and 11.09

(Fig. 5.13). Mean densities during this time period increased by only 3 - to 4 -fold at BCK 7.87 and 11.09. The largest changes in densities at most sites occurred after 1988.

Increases in densiiy were also observed at the five reference sites, although they were generally less than at most sites in Bear Creek (Fig. 5.13). Changes in mean densities over the 1985-92 time period ranged from 3-fold (UTK 0.6) to 32-fold (GCK 2.4) increases. Averaged among all five reference sites, benthos densities were 14 times higher in April 1992 than they were in April 1985.

The fact that estimated mean densities increased more among Bear Creek sites than among unimpacted reference sites (54-fold vs. 14-fold increases) during the 1985-92 time period suggests some recovery of the benthic macroinvertebrate community in Bear Creek. Another indication of recovery is the observation that in recent years many Bear Creek sites have exhibited higher total benthos densities than the reference sites. The average density of all five reference sites in April 1992 was 882 organisms per $0.1 \mathrm{~m}^{2}$. By comparison, five of the seven Bear Creek sites (BCK 3.25, 9.40, 9.91, 11.09, and 11.83) had higher densities than the reference site mean in April 1992. Total densities decreased in 1993 at all Bear Creek sites except BCK 7.87 by an average of $54 \%$. However, densities also decreased at the reference sites by an average of $24 \%$. Benthic invertebrate densities appear to be more stable over time at the reference sites than at the Bear Creek sites.

Although there were clear spatial differences in total densities among Bear Creek sites, the differences were not consistent among years. For example, BCK 12.36 had the highest mean density of all seven sites in 1990 , but the lowest densities in 1992 and 1993 (Fig. 5.13). Between 1990 and 1993, BCK 9.91 and 9.40 tended to have relatively high densities, whereas BCK 7.87 and 12.36 had relatively low densities.

Two-way ANOVAs were done to examine differences among all Bear Creek and reference sites in the most recent 6 years of sampling (1988-93); only the years after 1987 were analyzed to avoid the complications of comparing data obtained from two different processing laboratories. The site-sampling year interaction term was found to be statistically significant, indicating that patterns of change in densities at two or more sites were different from year to year (Table 5.6). On the other hand, slopes of the regression lines for density were not statistically significant. That is, based on the available data, a significant difference in the relative direction of linear change at the Bear Creek and reference sites was not detectable statistically. This could either mean that the density at none of the Bear Creek sites either improved or became worse, or that the temporal variability was too great to allow this technique to detect statistical differences; the result of this analysis was therefore inconclusive. Thus, changes in density followed a different pattern at some sites, but it is unclear whether the changes were persistent.

Relative abundance. The seven Bear Creek sampling sites differed not only in total densities of benthic macoinvertebrates 
Table 5.6. F-values and $p$-values for two-way analysis of variance (ANOVA) and regression analysis (testing for equal slopes across sites) using the response variables density, total richness, and EPT ${ }^{w}$ richness for Bear Creek and five reference sites ${ }^{b}$, April sampling period only, 1988-93

Source of variation $\quad \frac{d f^{c}}{\text { Num }} \quad \frac{\text { Density }}{\text { Denalue } p \text {-value }} \frac{\text { Total richness }}{\text { F-value } p \text {-value }} \frac{\text { EPT richness }}{\text { F-value } p \text {-value }}$

\section{Two-Way ANOVA}

$\begin{array}{lrrrrrrrr}\text { Site } & 11 & 143 & 5.94 & 0.0001 & 99.57 & 0.0001 & 85.38 & 0.0001 \\ \text { Sampling year } & 5 & 143 & 31.10 & 0.0001 & 19.38 & 0.0001 & 23.46 & 0.0001 \\ \text { Site*Sampling year } & 55 & 143 & 3.18 & 0.0001 & 2.19 & 0.0001 & 2.81 & 0.0001\end{array}$

Regression Analysis

$\begin{array}{lllllllll}\text { Site-Sampling year } & 11 & 191 & 1.00 & 0.4500 & 1.62 & 0.0953 & 2.34 & 0.0100\end{array}$

${ }^{a}$ EPT $=$ Ephemeroptera, Plecoptera, and Trichoptera.

${ }^{b}$ Reference sites included Grassy Creek (GCK 2.4); Gum Hollow Creek (GHK 1.6 and GHK 2.9); Mill Branch (MBK 1.6); and U. T. Farm Creek (UTK 0.6).

${ }^{c} \mathrm{df}=$ degrees of freedom; Num $=$ numerator; Den $=$ denominator.

but also in terms of the abundances of different taxonomic groups. The relative abundances of four groupings of benthic macroinvertebrates (Chironomidae, Coleoptera, EPT taxa, and all other taxa) at each Bear Creek site are shown in Fig. 5.14. The bentizos community at the uppermost site, BCK 12.36 , was dominated numerically by Chironomidae (true midges) in nearly every year; in most years, this family represented more than $90 \%$ of the organisms collected. Although they became relatively less common further downstream, chironomids remained important components of the benthos at most Bear Creek sites, comprising $40 \%$ or more of the April samples in most years at BCK 11.83 , 11.09, 9.91, 9.40, and 7.87. Chironomids were a small component of the benthos comniunity (less than 20\%) in Bear Creek at BCK 3.25 only. In terms of temporal trends, the relative abundance of chironomids appeared to decline at BCK 11.83, 11.09, and 9.91 between 1989 and 1993 (Fig. 5.14).

Members of the insect order Coleoptera (beetles) were rare or nonexistent at the uppermost site, BCK 12.36 , and generally comprised $20 \%$ or less of the benthos community at the lowest sites, BCK 3.25 and 7.87 (Fig. 5.14). They became a relatively large component of the benthos samples at the middle sites, BCK $11.83,11.09,9.91$ and 9.40 , especially in the more recent years.

The insect orders Ephemeroptera (mayflies), Plecoptera (stoneflies), and Trichoptera (caddisflies), which are generally pollution-intolerant (Lenat 1988), are grouped together as EPT taxa in Fig. 5.14. These orders were very small components of the benthos community at the uppermost Bear Creek sites, but began 





to represent $20 \%$ or more of the numbers collected at BCK 9.91 and below. EPT taxa accounted for nearly $40 \%$ of the benthos at BCK 7.87 in some years, and were the dominant grouping at BCK 3.25 in most years. Coincident with the decline in relative abundance of chironomids, the EPT taxa appeared to increase in relative abundance between 1989 and 1993 at BCK 11.83, 9.91, 9.40, and 7.87.

Figure 5.15 displays the densities of EPT at each of the Bear Creek sites in April of each year. Although densities (and relative contribution to the benthic community) of the combined EPT taxa grouping tended to increase at the upper sites in recent years (Fig. 5.14), much of this increase was due solely to stoneflies and caddisflies. Mayflies were absent or present only at low densities in all Bear Creek sites except BCK 3.25.

Among the reference sites, the Chironomidae generally comprised around 20 to $30 \%$ of the organisms collected (Fig. 5.16). Coleoptera represented 10 to $20 \%$ of the numbers in most years. The numerically most abundant grouping at all reference sites was the EPT taxa, which usually made up at least $40 \%$ of the collections. There were no consistent increases or decreases in the relative abundances of the different taxonomic groupings between 1985 and 1993. Unlike most Bear Creek sites, mayflies

(Ephemeroptera) made up a substantial portion of the combined EPT taxa grouping at all of the reference sites (Fig. 5.17). At most sites and dates, mayflies comprised $25 \%$ or more of the combined densities of EPT taxa.

\subsubsection{Richness}

Total Richness. Total richness (i.e, the total number of taxa per sample) of Bear Creek and reference site samples collected in April of each year are shown in Fig. 5.18. Total richness values were low at nearly all sites in 1985 and increased in subsequent years, particularly after 1987, a phenomenon most likely associated with the change in the sample processing laboratory. Highest mean richness values were recorded at many of the Bear Creek and reference sites in 1992.

Relative increases in total richness over time were very high at some Bear Creek sites. For example, the only organisms collected at BCK 12.36 in April 1985 were members of the family Chironomidae; this resulted in the total richness value of one. By April 1992, however, 13 taxa were identified in the BCK 12.36 samples, a 13-fold increase. BCK 9.91 experienced a 9-fold increase in mean total richness during this time period. Averaged over all Bear Creek sites, mean total richness increased by a factor of six. Sampling sites in the upper reaches of the watershed showed above-average increases $(13 \times, 8.6 \times$, and $9 \times$ at BCK 12.36, 11.83, and 9.91 respectively); total richness doubled or tripled between 1985 and 1992 at the other Bear Creek sites.

All reference sites also experienced increases in total richness between 1985 and 1992 (Fig. 5.18). Averaged over all sites, total richness increased by a factor of 2.3. UTK 0.6 showed the smallest relative increase (1.5x) and GCK 2.4 had the greatest increase $(3.1 \times)$.

Although many Bear Creek sites exhibited greater increases in total richness than reference sites, with the exception of BCK 3.25, the absolute values were nearly always lower (Fig. 5.18). Mean total richness values in Bear Creek samples from sites upstream of BCK 9.91 were always 20 or less, and mean values at BCK 7.87, 9.40, and 9.91 rarely exceeded 25 . In contrast, richness values at the reference sites and at BCK 3.25 were generally greater than 25 and frequently greater than 30 . 


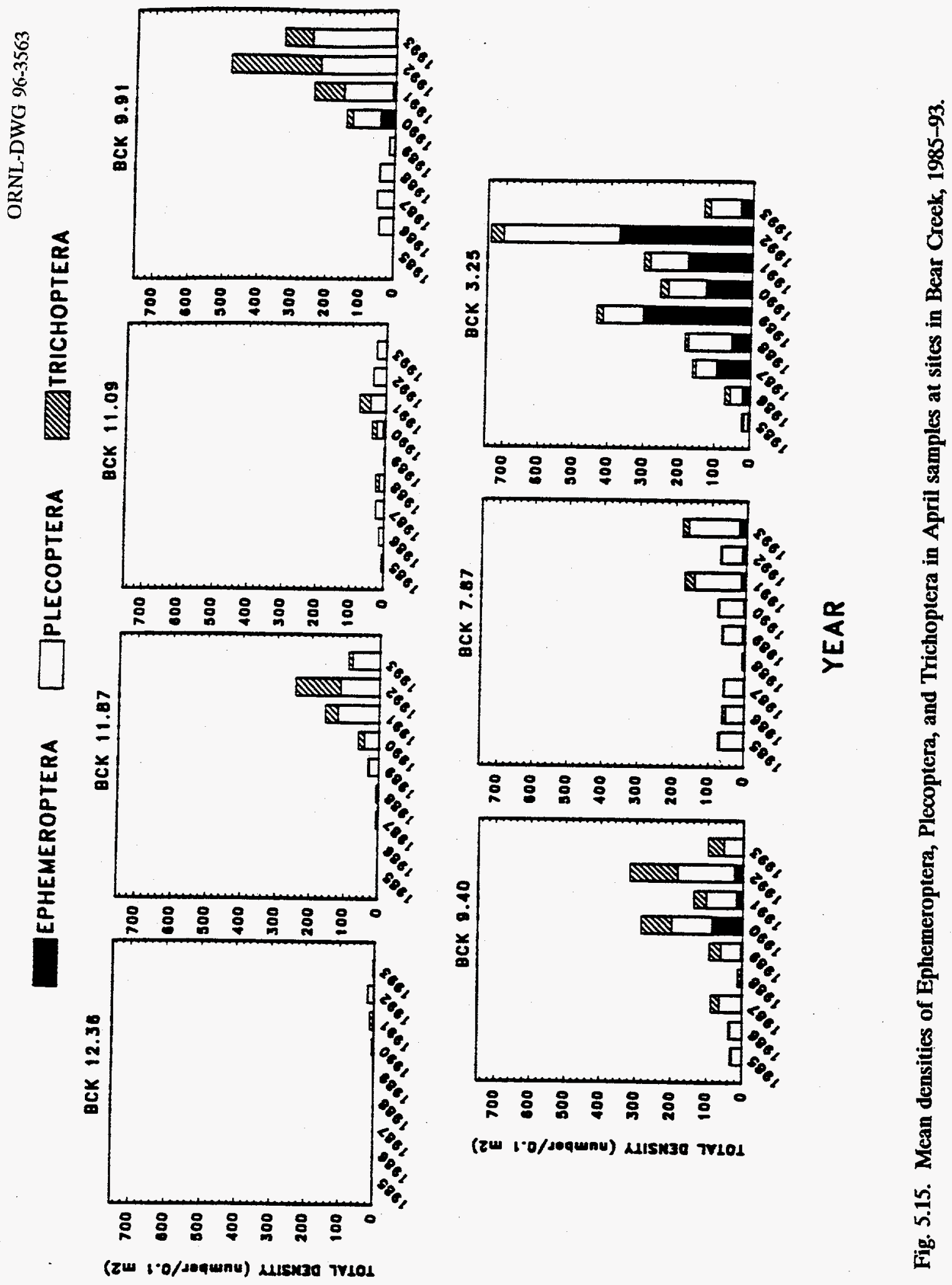



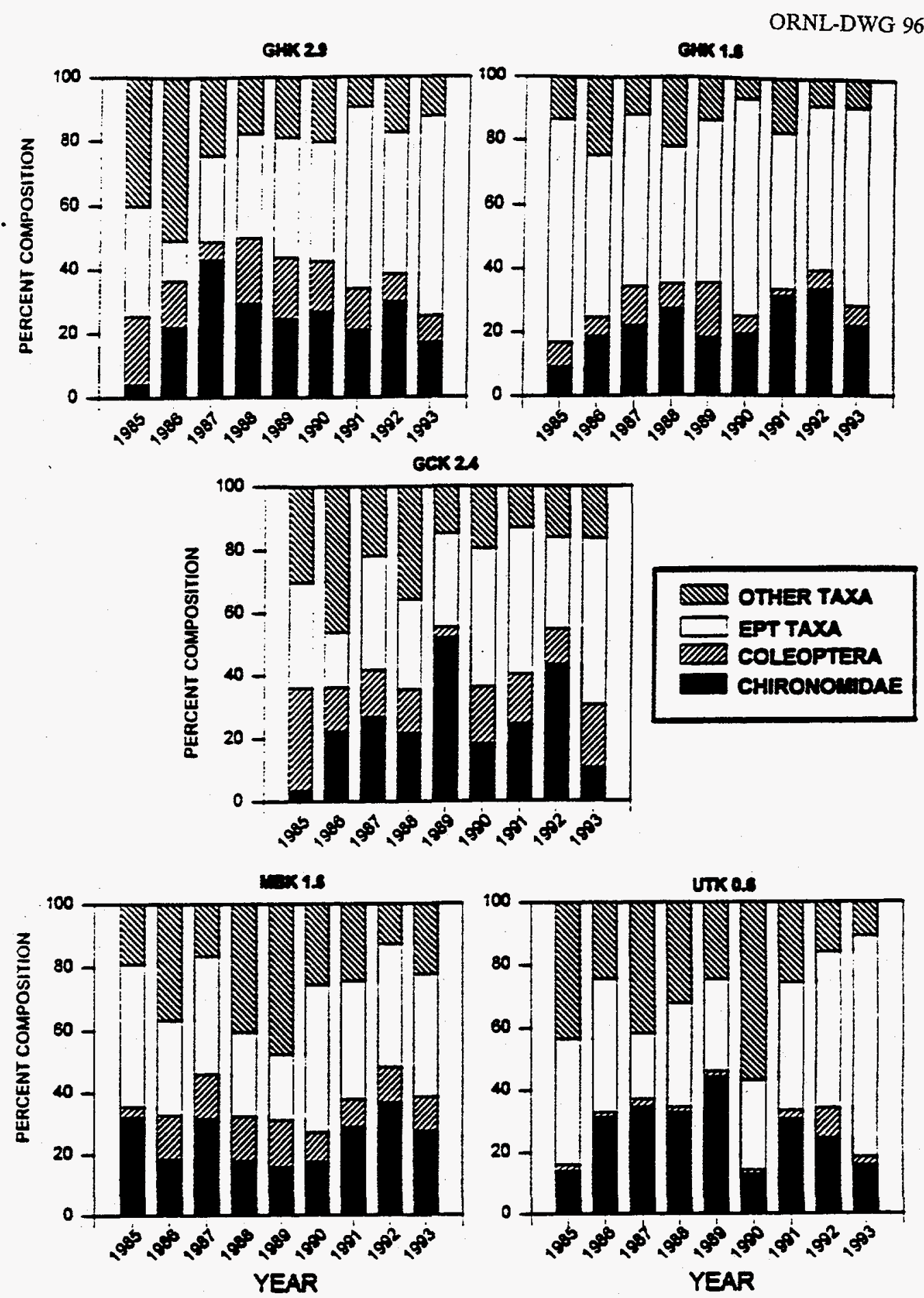

Fig. 5.16. Mean percent composition (i.e, mean percentage of total density) of selected benthic macroinvertebrate taxonomic groups in April samples at sites in Grassy Creek, Gum Hollow Branch, Mill Branch, and U.T. Farm Creek, 1985-93. GCK = Grassy Creek kilometer, GHK $=$ Gum Hollow kilometer: MBK = Mill Branch kilometer; UTK = U.T. Farm Creek kilometer. 
ORNL-DWG 96-3565
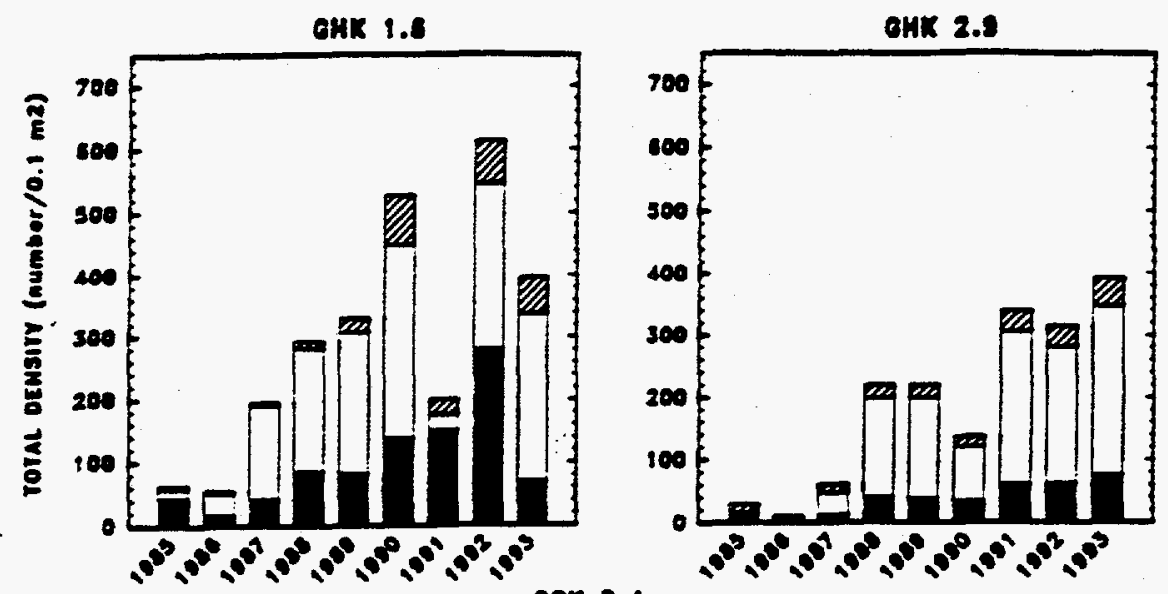

$\operatorname{cer} 2.4$

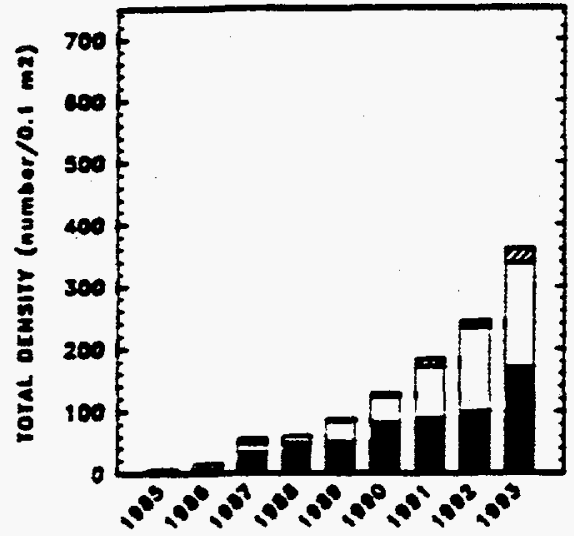

UIIMTRICHOPTERTA

DPLECOPTERA

EPHEMEROPTERA

un 1.8


rean

YEAR

Fig. 5.17. Mean densities of Ephemeroptera, Plecoptera, and Trichoptera in April samples at sites in Grassy Creek, Gum Hollow Branch, Mill Branch, and U.T. Farm Creek, 1985-93. GCK = Grassy Creek kilometer; GHK = Gum Hollow kilometer; MBK = Mill Branch kilometer; UTK = U.T. Farm Creek kilometer. 
ORNL-DWG 96-3566


Fig. 5.18. Mean total richness of the benthic macroinvertebrate communities at sites in Bear Creek, Grassy Creek, Gum Hollow Branch, Mill Branch, and U.T. Farm Creek in April of each year, 1985-93. Vertical bars represent \pm 1 SE. GCK $=$ Grassy Creek kilometer; $G H K=$ Gum Hollow kilometer; MBK $=$ Mill Branch kilometer; UTK $=$ U.T. Farm Creek kilometer. 
As for density, two-way ANOVAs were done to examine differences among all sites in the most recent 6 years of sampling (1988-93) only. The sitesampling year interaction term was found to be statistically significant, indicating that patterns of change in total richness between two or more sites were different from year to year (Table 5.6). In contrast, slopes of the regression lines for total richness were not statistically significant. That is, based on available data, a significant difference in the relative direction of linear change at the Bear Creek and reference sites was not detectable statistically. Thus, as was the case for density, changes in total richness followed a different pattern at some sites, but it was unclear whether the changes were persistent.

EPT Richness. The numbers of EPT taxa generally increased at Bear Creek and reference sites between 1985 and 1993

(Fig. 5.19). Highest mean EPT richness values for nearly all sites were observed in either 1992 or 1993.

The greatest increases in EPT richness over time occurred at the uppermost Bear Creek sites. For example, in 1985, BCK 12.36 had an EPT richness value of zero; no mayflies, stoneflies, or caddisflies were collected at this site. By 1992, BCK 12.36 samples contained an average of 3.7 different taxa from these insect orders. Similarly, mean EPT richness at $\mathrm{BCK} 11.83$ increased from 0.3 (only one of the three simples at that site had a single EPT taxon) in 1985 to 8 in 1992, a 24-fold increase. EPT richness values at BCK 9.91 increased by a factor of 42 during this period. Averaged over all Bear Creek sites, EPT richness increased by a factor of 13 between April 1985 and April 1992.

All reference sites exhibited increases in mean EPT richness values between 1985 and 1992; and as for density and total richness, the magnitude of the increases was much less than at the Bear Creek sites. Averaged over all reference sites, EPT richness increased by a factor of 2.6 . UTK 0.6 showed the smallest relative increase (1.3x) and GCK 2.4 had the greatest increase (3.6x). Despite the large increase, however, GCK 2.4 usually had the lowest EPT richness values of any reference sites (Fig. 5.19).

As with total richness, the absolute values of EPT richness at Bear Creek sites were generally lower than those at the reference sites. With the exception of BCK 3.25 and 7.87, the highest EPT richness values at Bear Creek sites were less than 15 (Fig. 5.19). Maximum EPT richness at the uppermost Bear Creek sites, BCK 12.36, 11.83, and 11.09 , were $3.7,8$, and 6 respectively. On the other hand, the number of EPT taxa per sample at the reference sites peaked at an average of 19.2 and, except prior to 1987 , remained well above an average of 5 EPT taxa per sample.

Two-way ANOVAs were done to examine differences in EPT richness among all sites; as for density and total richness, only the most recent 6 years of sampling (1988-93) were included. The site-sampling year interaction term was found to be statistically significant, indicating that patterns of change in EPT richness between two or more sites differed from year to year (Table 5.6). Unlike the density and total richness comparisons, the slopes for EPT richness were statistically significant, indicating that linear change of at least one of the seven Bear Creek sites and five reference sites differed.

\subsubsection{Discussion}

Densities, total richness, and EPT richness of benthic macroinvertebrates in Bear Creek all showed similar trends between 1985 and 1993, i.e., general increases throughout the time period. 
ORNL-DWG 96-3567
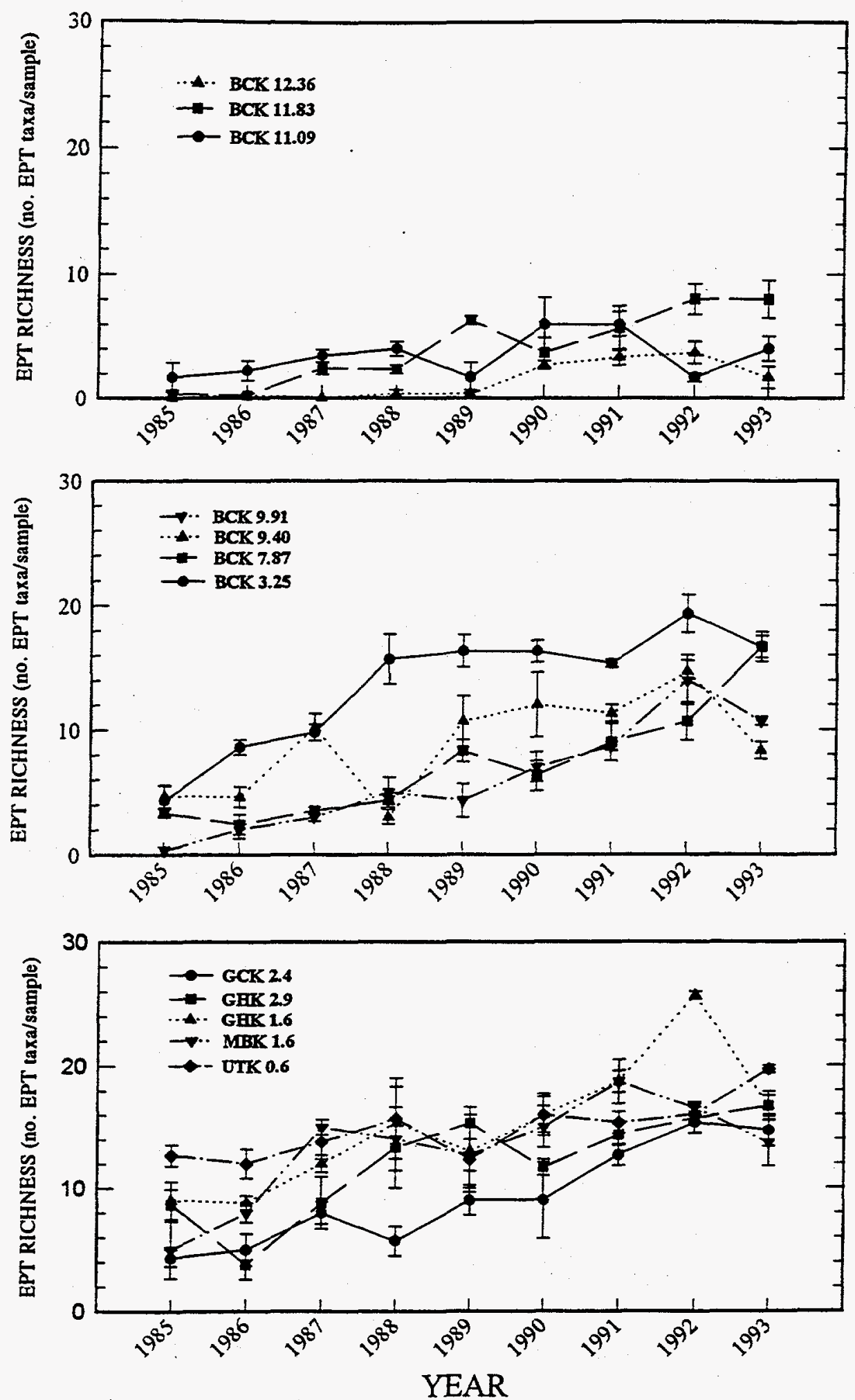

Fig. 5.19. Mean richness of Ephemeroptera, Plecoptera, and Trichoptera (i.e. EPT richness) at sites in Bear Creek, Grassy Creek, Gum Hollow Branch, Mill Branch, and U.T. Farm Creek in April of each year, 1985-93. Vertical bars represent \pm 1 SE. GCK $=$ Grassy Creek kilometer; GHK = Gum Hollow kilometer; MBK = Mill Branch kilometer; UTK = U.T. Farm Creek kilometer. 
Similar trends in these same parameters were also seen at the five unimpacted reference sites, although to a lesser degree. As has been hypothesized for other biological monitoring projects on ORR (Smith 1992b, Smith 1994), much of the difference observed between 1985 and 1987 vs $1988-93$ probably reflects differences in processing efficiencies between the two laboratories that have sorting efficiencies (i.e., the number of organisms actually removed from a sample of the total number of organisms actually in a sample) between the two laboratories that have processed samples since 1985 . Efficiency has improved from $<70 \%$ removal of all organisms before 1988 to $>90 \%$ after 1987 , an improvement that was most likely the result of more rigorous QA procedures. However, the fact that the amounts of increase at most Bear Creek sites were generally greater than the amounts at the reference sites may indicate that the benthic macroinvertebrate community in Bear Creek is responding favorably to remedial actions. BCK 9.91 exhibited the most change (i.e., largest increases in density and richness) of all Bear Creek sites. The benthos community at this site was very poor in 1985 , but showed considerable improvement, particularly after 1989. However, most Bear Creek sites, especially the uppermost sites, still exhibited lower benthos densities and richness compared to reference sites, indicating that recovery from past and/or continued stresses is not complete.

Some of the improvement in the macroinvertebrate community after 1989 may be attributable simply to increased stream flows. The 1985-88 drought resulted in low stream flows during the early years of monitoring in Bear Creek (Southworth et al. 1992). The precipitation deficit was particularly acute during the November-April time periods that preceded the benthos sampling reported here; precipitation was $60,57,83$, and $71 \%$ of normal in $1985,1986,1987$, and 1988 respectively. The hydrograph for lower Bear Creek was dominated by extensive periods of low flow in 1986 and 1987; in both years the mean annual flow at BCK 4.55 was about $50 \%$ of that estimated for earlier time periods (Southworth et al. 1992). The reach of Bear Creek between BCK 9.53 and 11.17 had many days of zero flow during this period. Low stream flows not only reduced the amount of habitat for benthic organisms but also provided less water for dilution of contaminated groundwater that was potentially toxic. Increases in benthic macroinvertebrate densities and richness in many Bear Creek and reference sites generally occurred after 1988 when normal precipitation and stream flow resumed.

Extremely high water temperatures were recorded twice during December 1992 at BCK 9.91 (Section 2.6).

Temperature readings of $70.3^{\circ} \mathrm{C}$ and $78.0^{\circ} \mathrm{C}$ would severely impact the benthic macroinvertebrate community at this site and would be expected to cause significant decreases in density and or taxonomic richness. In the absence of effluent discharges to Bear Creek, temperatures this high would appear to be an artifact. However, the fact that some elevation of temperatures remained after the apparent spikes would suggest that some spike may have occurred (although probably of less magnitude). Both density and richness values decreased at BCK 9.91 in April 1993, compared to. April 1992, but these parameters also showed coincident declines at many other Bear Creek sites (both upstream and downstream from BCK 9.91) and reference sites. (See, for example, Fig. 5.13). Even if the benthic community at BCK 9.91 was adversely impacted by high water temperatures in December 1992, drift from upstream sites could have been sufficient to repopulate the site before April 1993. 
Toxicity tests (Section 3.3.1) indicated that water samples from the uppermost Bear Creek sites were frequently toxic to the invertebrate Ceriodaphnia but not to fathead minnows. Acute toxicity, as measured by Ceriodaphnia mortality, was detected at BCK 12.36, 11.83, and 11.09. Chronic toxicity, as reflected by depression of Ceriodaphnia reproduction, was evident in water collected at $\mathrm{BCK} 12.36,11.83$, and perhaps BCK 9.91. Thus, water from upper Bear Creek sites was demonstrably toxic to this invertebrate test organism. Based on these toxicity tests, water quality factors probably adversely affect the abundance and/or taxonomic richness of benthic macroinvertebrates in upper Bear Creek, regardless of habitat limitations (i.e., low stream flows and high water temperatures). As noted in Section 2.4, water quality in Bear Creek can be characterized by (1) high concentrations of dissolved salts resulting from infiltration of contaminated groundwater near the S-3 Ponds; (2) elevated concentrations of some trace ions in upper Bear Creek that decline to approximately background levels within a short distance downstream; and (3) elevated levels of metals in the sediments in the upper stream reaches. All of these factors could adversely affect benthic macroinvertebrates and could contribute to the patterns in density and richness that were observed. The particular dissolved contaminants that are responsible for the observed Ceriodaphnia toxicities have not been identified, but elevated concentrations of aluminum (Southworth et al. 1992), nickel, or calcium (Sect. 3.4) are possibilities. The continued absence or low abundance of mayflies in the upper Bear Creek sites, particularly when stoneflies and caddisflies appear to be much less affected, may be related to the presence of dissolved metals, particularly upstream of the SS-5 spring. Mayflies tend to be one of the most sensitive groups of aquatic insects to metals, whereas stoneflies and caddisflies are less affected (Wiederholm 1984).

Erosion and sedimentation have probably limited the distribution and abundance of benthic invertebrates. Construction and other soil-disturbing activities in upper Bear Creek Valley since the early 1980 s have resulted in the accumulation of gravels and fine sediments, especially at BCK 9.91 and 7.87; these impacts are believed to have reduced the density and biomass of fish in upper Bear Creek (Section 5.1.4). Deposition of fine sediments reduces substrate heterogeneity and thus habitat diversity for benthos as well, and it also decreases habitat stability during spates (e.g., Wiederholm 1984). Continuing activities in the watershed that result in soil erosion and sedimentation can be expected to delay the recovery of benthic invertebrates in Bear Creek.

\subsubsection{Summary and Conclusions}

Further studies of the benthic macroinvertebrate community in Bear Creek continue to show the presence of degraded conditions. The greatest evidence of impact continues to be apparent in the upper reaches of Bear Creek, where a taxonomically depauperate benthic fauna existed. Increases in taxonomic richness with increasing distance from the Y-12 Plant demonstrated that gradual downstream recovery occurs and that, within $3.25 \mathrm{~km}$ of the stream's confluence with East Fork Poplar Creek, full recovery is apparent. Since mayflies are very sensitive to the presence of metals, their persistent absence and/or very low abundance and richness at sites upstream of BCK 3.25 suggests that metals are the most likely source of stress to the stream biota. Other factors such as siltation/sedimentation associated with activities that disturb surrounding soils, low flow conditions during periods of little 
rainfall, and unusual increases in temperatures may also be a source of stress to the biota.

Although the macioinvertebrate community exhibited strong evidence of impact downstream to BCK 7.87 , some recovery has occurred since 1987 . Substantial increases have occurred in richness and density upstream to BCK 12.36 , particularly since 1988 . It was not yet clear whether the recovery exhibited by the macroinvertebrate community was associated with remedial actions and/or changes in natural environmental conditions (e.g., increased rainfall resulting in the dilution of toxicants or the improvement of habitat quality).

\subsubsection{Future Studies}

The benthic macroinvertebrate community will continue to be sampled on a quarterly basis from seven sites in Bear Creek and five reference sites, with primary emphasis remaining on the response of the invertebrate community to remedial actions in Bear Creek watershed and assisting in the identification of the factors(s) responsible for any observed impacts. The reference site on Grassy Creek (GCK 2.4) will be replaced with a reference site on Pinhook Branch (PHK 1.6), a site previously used as a benthos reference site (Southworth et al. 1992) that is now being used as a reference site for the fish community monitoring task. Increasingly difficult accessibility to GCK 2.4 and habitat alterations associated with expansion of the DOE rifle range in Grassy Creek's headwaters in 1989, have necessitated the need for an alternate reference site. The use of PHK 1.6 during the initial years of the Bear Creek monitoring program, and the continued collection of samples through January 1991, will minimize data gaps.

Although samples will continue to be collected on a quarterly basis, only samples collected in the spring and fall will be processed; samples collected during the fall sampling periods since 1987 will be incorporated into the next Bear Creek report. Samples collected in the winter and summer will be retained in storage to provide further resolution of the data only if necessary. Thus far, differences between the reference sites and those sites in Bear Creek exhibiting impact have been substantial. Detection of differences as great as these do not require a data set as large as the one that would be provided by processing all four quarters of samples. The factor(s) triggering the need for processing the stored samples (i.e., summer/winter) will include but not necessarily be limited to strongly significant (1) spatial and/or (2) temporal differences that were previously unobserved and that persist for more than 2 years. In determining what constitutes a strongly significant difference, greater consideration will be given to the results of the statistical analyses on the most sensitive parameters, such as total taxonomic richness and EPT richness. Additionally, the magnitude of change(s) between sites or years will also be considered. The number of stored samples to be processed will be determined by the ability to confirm or refute the results that triggered the need for processing these samples. In most cases, the number of samples needed would include those required to provide at least 2 consecutive years of confirmation or refutation. The only samples to be processed will be those needed to help verify the accuracy of the observed changes (e.g., changes at the reference site(s) vs changes at an affected site). 


\section{REFERENCES}

Berkman, H. E., and C. F. Rabeni. 1987. Effect of siltation on stream fish communities. Environ. Biol. Fishes 18:285-294.

Borders, D. M., J. A. Watts, R. B. Clapp, B. J. Fredrick, S. M. Gregory, and T. D. Moore. 1993. Hydrologic Data Summary for the White Oak Creek Watershed at Oak Ridge National Laboratory, Oak Ridge, Tennessee (January-December 1992).

ORNL/ER-166. Oak Ridge National Laboratory, Oak Ridge, Tennessee.

Bowman, K. O., and M. A. Kastenbaum. 1975. Sample size requirement: single and double classification experiments. IN Harter, H. L. and D. B. Owen, coeditors, and J. M. Davenport, Managing Editor (edited by the Institute of Mathematical Statistics), Selected Tables in Mathematical Statistics, Volume III. American Mathematical Society, Providence, Rhode Island.

Burkhead, N. M., and R. E. Jenkins. 1991. Fishes. pp. 321-409. In K. Terwilliger (coordinator), Virginia's endangered species. McDonald and Woodard Publishing Co., Blacksburg, Virginia.

Burris, J. A., M. S. Bamford, and A. J. Stewart. 1990. Behavioral responses of marked snails as indicators of in situ toxicity. Environ. Toxicol. Chem. 9:69-76.

Burton, G. A., D. Nimmo, D. Murphey, and F. Payne. 1987. Stream profile determinations using microbial activity assays and Ceriodaphnia. Environ. Toxicol. Chem. 6:505-513.

Carle, F. L., and M. R. Strub. 1978. A new method for estimating population size from removal data. Biometrics 34:621-630.

Chutter, F. M. 1969. The effects of silt and sand on the invertebrate fauna of streams and rivers. Hydrobiol. 34:57-76.

Earthinfo Digital DataBase. 1992. Earthinfo's USGS Daily Values: Compact Disk. Earthinfo, Inc., Bculder, Colorado.

Elliot, J. M. 1977. Some methods for the statistical analysis of samples of benthic invertebrates. Science Publication No. 25. Freshwater Biological Association, Ambleside, England.

Ellis, M. M. 1936. Erosion silt as a factor in aquatic environments. Ecol. 17:29-42.

EAD (Environmental Affairs Department). 1984. Monitoring data from upper Bear Creek. Y/TS-45. Y-12 Plant, Oak Ridge, Tennessee. 
EPA (Environmental Protection Agency). 1984. Extraction and analysis of priority pollutants in biological tissue, Method PPB 12/83. Environmental Services Division, Region IV, Analytical Support Branch, U.S. Environmental Protection Agency, Athens, Georgia. Mimeo.

EPA (Environmental Protection Agency). 1991. Methods for the determination of metals in environmental samples. EPA-600/4-91-010. Environmental Monitoring Systems Laboratory, U.S. Environmental Protection Agency, Cincinnati, Ohio.

Energy Research and Development Administration. 1975. Environmental Analysis. Oak Ridge Operations. Vol. 6. Oak Ridge, Tennessee.

Energy Systems. 1987. Environmental Surveillance of the U.S. Department of Energy Oak Ridge Reservation and Surrounding Environs during 1986. ES/ESH-1/V1\&V2, Oak Ridge Y-12 Plant, Oak Ridge, Tennessee.

Etnier, D. A., and W. C. Starnes. 1993. The Fishes of Tennessee. The University of Tennessee Press, Knoxville. 681 pp.

Foltz, J. W. 1982. Fish species diversity and abundance in relation to stream habitat characteristics. Southeast. Assoc. Fish and Wildl. Agencies 1982:305-311.

FDA (U.S. Department of Agriculture Food and Drug Administration). 1984a. Action level for methyl mercury in fish. Fed. Regist. 49(224):45663.

FDA (U.S. Department of Agriculture Food and Drug Administration). 1984b. Polychlorinated biphenyls (PCBs) in fish and shellfish: Reduction of tolerances; Final Decision. Fed. Regist. 49(100):21520.

Gammon, J. R. 1970. The effect of inorganic sediment on stream biota. U.S. Environmental Protection Agency, Water Pollution Control Research Service 18050 DWC 12/70:1-141.

Garman, G. C., and T. F. Waters. 1983. Use of the size-frequency (Hynes) method to estimate annual production of a stream fish population. Can. J. Fish. Aquat. Sci. 40:2030-2034.

Greeson, P. E., T. A. Ehlke, G. A. Irwin, B. W. Lium, and K. V. Slack. 1977. Methods for collection and analysis of aquatic biological and microbiological samples. Book 5 , Chapter 4A. pp. 1-322. In U. S. Geological Survey, Techniques of Water-Resources Investigations of the United States Geological Survey. U.S. Government Printing Office, Washington, D.C.

Griest, W. H., A. J. Stewart, R. L. Tyndall, J. E. Canton, C.-h Ho, K. S. Ironside, W. M. Caldwell, and E. Tan. 1993. Chemical and toxicological testing of composed explosives-contaminated soil. Environ. Toxicol. Chem. 12:1105-1116. 
Hinzman, R. L. 1993. Second report on the Oak Ridge Y-12 Plant Biological Monitoring and Abatement Program for East Fork Poplar Creek. Y/TS-888. Oak Ridge National Laboratory, Oak Ridge, Tennessee.

Hynes, H. B. N. 1970. The Ecology of Running Water. University of Toronto Press. Toronto, Ontario.

Hynes, H. B. N. 1974. The biology of polluted waters. University of Toronto Press. Toronto, Ontario.

Jop, K. M., and A. M. Askew. 1994. Toxicity identification evaluation using a short-term chronic test with Ceriodaphnia dubia. Bull. Environ. Contam. Toxicol. 53:91-97.

Karr, J. R. 1981. Assessment of biotic integrity using fish communities. Fisheries 6:21-27.

Karr, J. R. 1987. Biological monitoring and assessment: A conceptual framework. Environ. Manag. 11:249-256.

Karr, J. R. 1991. Biological integrity: A long-neglected aspect of water resource management. Ecol. Appl. 1:165-184.

Karr, J. R., K. D. Fausch, P. L. Angermeier, P. R. Yant, and I. J. Schlosser. 1986. Assessing biological integrity in running waters: A method and its rationale. Illinois Natural History Survey Special Publication 5.

Kelts, K., and K J. Hsu. 1978. Freshwater carbonate sedimentation. pp. 295-323. In A. Lerman (ed.), Lakes: Chemistry, Geology, Physics. Springer-Verlag, New York.

Kornegay F.C., D. C. West, L. W. McMahon, J. B. Murphy, L. G. Shipe, and W. S. Koncinski. 1993. Oak Ridge Reservation environmental report for 1992. ES/ESH-31/V1. Martin Marietta Energy Systems, Inc., Oak Ridge, Tennessee.

Kszos, L. A., A. J. Stewart, L. F. Wicker, and G. M. Logsdon. 1989. Environmental Sciences Division Toxicology Laboratory Standard Operating Procedures. ORNL/TM11194. Oak Ridge National Laboratory, Oak Ridge, Tennessee.

Kszos, L. A., and P. A. Taylor. 1992a. Toxicity tests justify modification in precipitation process at the Coal Yard Runoff Treatment Facility. In Environmental Sciences Division Annual Progress Report for Period Ending September 30, 1991. pp. 60-61. ORNL-6706. Oak Ridge National Laboratory, Oak Ridge, Tennessee.

Kszos, L. A. A. J. Stewart, and P. A. Taylor. 1992b. An evaluation of nickel toxicity to Ceriodaphnia dubia and Daphnia magna in a contaminated stream and in laboratory tests. Environ. Toxicol. Chem. 11:1001-12.

Lenat, D. R. 1988. Water quality assessment of streams using a qualitative collection method for benthic macroinvertebrates. J. North Am. Ben. Soc. 7:222-233. 
Loar, J. M., M. J. Sale, G. F. Cada, D. K. Cox, R. M. Cushman, G. K. Eddlemon, J. L. Elmore, A. J. Gatz, Jr., P. Kanciruk, J. A. Solomon, and D. S. Vaughn. 1985. Application of habitat evaluation models in southern Appalachian trout streams. ORNL/TM-9323. Oak Ridge National Laboratory, Oak Ridge, Tennessee. 310 pp.

Loar, J. M. 1994. Fourth report on the Oak Ridge National Laboratory Biological Monitoring and Abatement Program for White Oak Creek Watershed and the Clinch River. ORNL/TM-11544. Oak Ridge National Laboratory, Oak Ridge, Tennessee.

Lotrich, V. A. 1973. Growth, production, and community composition of fishes inhabiting a first-, second-, and third-order stream of eastern Kentucky. Ecol. Monogr. 43:377397.

McMaster, W. M. 1967. Hydrologic data for the Oak Ridge area, Tenn. U.S. Geological Survey-Water Supply Paper No. 1838-N. U.S. Government Printing Office, Washington, D.C.

Minshall, G. W., R. C. Petersen, Jr., and C. F. Nimz. 1985. Species richness in streams of different size from the same drainage basin. Amer. Nat. 124:16-38.

Muncy, R. J., G. J. Atchinson, R. V. Bulkley, B. W. Menzel, L. G. Perry, and R. C. Summerfelt. 1979. Effects of suspended solids and sediment on reproduction and early life of waimwater fishes: A review. Environmental Protection Agency, Corvallis Environmental Research Laboratory Publication, EPA-600/3-79-042.

Neves, R. J. and G. B. Pardue. 1983. Abundance and production of fishes in a small Appalachian stream. Trans. Acad. Fish. Soc. 112:21-26.

Nimmo, D. R., M. H. Dodson, P. H. Davies, J. C. Greene, and M. A. Kerr. 1990. Three studies using Ceriodaphnia to detect nonpoint sources of metals from mine drainage. Res. J. Water Pollu. Control Fed. 62:7-15.

Norberg-King, T. J., E. J. Durhan, G. T. Ankley, and E. Robert. 1991. Application of toxicity identification evaluation procedures to the ambient waters of the Colusa basin drain, California. Environ. Toxicol. Chem. 10:891-900.

Norusis, M. J. 1993. SPSS: SPSS for Windows, Base System User's Guide, Release 6.0. SPSS Inc., Chicago, Illinois.

Opresko, D. M., B. E. Sample, and G. W. Suter II. 1994. Toxicological benchmarks for wildlife: 1994 revision. ES/ER/TM-86/R1. Oak Ridge National Laboratory, Oak Ridge, Tennessee.

Peterson, M. J., G. R. Southworth, and K. D. Ham. 1994. Effect of sublethal chlorinated discharges on PCB accumulation in transplanted asiatic clams (Corbicula fluminea). Water Air Soil Pollut. 73:169-178. 
Railsback, S. F., B. D. Holcomb, and M. G. Ryon. 1989. A computer program for estimating fish population sizes and annual production rates. ORNL/TM-11061. Oak Ridge National Laboratory. Oak Ridge, Tennessee. 62 pp.

Ryon, M. G. 1993. Fishes. In R. L. Hinzman et al. 1993, Second report on the Oak Ridge Y-12 Plant Biological Monitoring and Abatement Program for East Fork Poplar Creek. Y/TS-888. Oak Ridge Y-12 Plant. Oak Ridge, Tennessee.

Ryon, M. G. 1994. Fishes. In J. G. Smith et al. 1994. Second Report on the Oak Ridge K-25 Site Biological Monitoring and Abatement Program for Mitchell Branch. ORNL/TM-12150. Oak Ridge National Laboratory. Oak Ridge, Tenn. 237 pp.

Ryon, M. G., and E. M. Schilling. 1994. Fishes. In R. L. Hinzman et al. 1994. Third Report on the Oak Ridge Y-12 Plant Biological Monitoring and Abatement Program for East Fork Poplar Creek. Y/TS-889. Oak Ridge Y-12 Plant, Oak Ridge, Tennessee.

SAIC (Science Applications International Corporation). 1993. Remedial Investigation Work Plan for Bear Creek Valley Operable Unit 4 (Shallow Groundwater in Bear Creek Valley) at the Oak Ridge Y-12 Plant, Oak Ridge, Tennessee. DOE/OR/01-1115\&D3 (Y/ER-56\&D3). Oak Ridge, Tennessee.

SAIC (Science Applications International Corporation). 1994. Remedial Investigation Report on Bear Creek Valley Operable Unit 2 (Rust Spoil Area, Rust Spoil Area 1, and SY-200 Yard) at the Oak Ridge Y-12 Plant, Oak Ridge, Tennessee. V.1. Main text. DOE/OR/01-1273/V1\&D0.

SAS Institute. 1985a. SAS User's Guide: Basics, Version 5 Edition. SAS Institute, Inc., Cary, North Carolina.

SAS Institute. 1985b. SAS User's Guide: Statistics, Version 5 Edition. SAS Institute, Inc., Cary, North Carolina.

Schilling, E. M. 1993. Fishes. In T. L. Ashwood et al. 1993. Seventh Report on the Oak Ridge National Laboratory Biological Monitoring and Abatement Program for White Oak Creek Watershed and the Clinch River. Draft ORNL/TM. Oak Ridge National Laboratory, Oak Ridge, Tenn.

Schilling, E. M. 1994. Fishes. In T. L. Ashwood et al. 1994. Eighth Report on the Oak Ridge National Laboratory Biological Monitoring and Abatement Program for White Oak Creek Watershed and the Clinch River. Draft ORNL/TM-12767. Oak Ridge National Laboratory. Oak Ridge, Tenn.

Schilling, E. M. 1995. Fishes. In R. L. Hinzman et al. 1995. Third report on the Oak Ridge K-25 Site Biological Monitoring and Abatement Program for Mitchell Branch. ORNL/TM-12790. Oak Ridge National Laboratory. Oak Ridge, Tennessee. 
Smith, J. G. 1992a. Biological Monitoring and Abatement Program (BMAP) Benthic Macroinvertebrate Monitoring Project Sample Collection and Storage QA Plan. QAP-X-90-ES-068. Oak Ridge National Laboratory, Oak Ridge, Tennessee.

Smith, J. G. 1992b. Benthic macroinvertebrates. In J. M. Loar (ed.), Sixth annual report on the ORNL Biological Monitoring and Abatement Program. ORNL/TM-12083, Draft Report. Oak Ridge National Laboratory, Oak Ridge, Tennessee.

Smith, J. G. 1993. Benthic macroinvertebrates. In Ashwood, T.L. (ed.), Seventh Annual Report on the ORNL Biological Monitoring and Abatement Program. Draft ORNL Report, Oak Ridge National Laboratory, Oak Ridge, Tennessee.

Smith, J. G. 1994. Benthic macroinvertebrates. In J. G. Smith (ed.), Second report on the Oak Ridge K-25 Site Biological Monitoring and Abatement Program for Mitchell Branch. ORNL/TM-12150. Oak Ridge National Laboratory, Oak Ridge, Tennessee.

Sorensen, D. L., M. M. McCarthy, E. J. Middlebrooks, and D. B. Porcella. 1977. Suspended and dissolved solid effects on freshwater biota: A review. Environmental Protection Agency, Corvallis Environmental Research Laboratory Publication, EPA-600/3-77-042.

Southworth, G. R. 1990. PCB Concentrations in Stream Sunfish (Lepomis auritus and L. macrochirus) in Relation to Chronic Point Sources. Water Air Soil Pollut. 51:287-296.

Southworth, G. R., J. M. Loar, M. G. Ryon, J. G. Smith, A. J. Stewart, and J. A. Burris. 1992. Ecological effects of contaminants and remedial actions in Bear Creek. ORNL/TM 11977. Oak Ridge National Laboratory, Oak Ridge, Tennessee.

Southworth, G. R., M. J. Peterson, and R. R. Turner. 1994a. Changes in concentrations of selenium and mercury in largemouth bass following elimination of fly ash discharges to a quarry. Chemosphere 29:71-79.

Southworth, G. R., M. J. Peterson, S. M. Adams, and B. G. Blaylock. 1994b. Estimation of appropriate background concentrations for assessing mercury contamination in fish. Bull. Environ. Contam. Toxicol. 53:211-218.

Starnes, W. C., and D. A. Etnier. 1980. Fishes. p B.1 through B.134. In D. C. Eager and R. M. Hatcher (eds.), Tennessee's Rare Wildlife. Tennessee Department of Conservation, Nashville, Tennessee.

Steel, R. G. D., and J. H. Torrie. 1960. Principles and Procedures of Statistics, with Special Reference to Biological Sciences. McGraw Hill, New York.

Stewart, A. J. 1988. Alkalinity dynamics in a hardwater prairie-margin stream. Arch. Hydrobiol. 112:335-350. 
Stewart, A. J. 1994. Ambient bioassays for assessing water-quality conditions in receiving streams. Ecotoxicology (submitted).

Stewart, A. J., L.A. Kszos, B.C. Harvey, L.F. Wicker, G.J. Haynes, and R.D. Bailey. 1990. Ambient toxicity dynamics: Assessments using Ceriodaphnia and fathead minnow larvae in short-term tests. Environ. Toxicol. Chem. 9:367-379.

Stewart, A. J., and J. M. Loar. 1990. Spatial and temporal variation in biomonitoring data. pp. 91-124. In S. L. Loeb and A. Spacie (eds.), Biological Monitoring of Aquatic Systems. Lewis Publishers, Boca Raton, Florida.

Tennessee Valley Authority (TVA). 1985. Instream contaminant study, Task 4: Fish sampling and analysis. Report to U.S. Department of Energy, Oak Ridge Operations Office. Tennessee Valley Authority, Office of Natural Resources and Economic Development, Knoxville, Tennessee.

Turner, R. R., M. A. Bogle, R. B. Clapp, K. C. Dearstone, R. B. Drier, T. O. Early, S. E. Herbes, J. M. Loar, P. D. Parr, and G. R. Southworth. 1991. Remedial Investigation Work Plan for Bear Creek (Y02-S600) at the Oak Ridge Y-12 Plant, Oak Ridge, Tennessee. ES/ER-19\&D2 (Y/ER/Sub-90/99928/2). Oak Ridge National Laboratory, Oak Ridge, Tennessee.

Van Winkle, W., R. W. Counts, J. G. Dorsey, J. W. Elwood, V. W. Lowe Jr., R. McElhaney, S. D Schlotzhauer, F. G. Taylor, Jr., and R. R. Turner. 1984. Mercury contamination in East Fork Poplar Creek and Bear Creek. ORNL/TM-8894. Oak Ridge National Laboratory, Oak Ridge, Tennessee.

Vannote, R. L., G. W. Minshall, K. W. Cummins, J. R. Sedel, and C. E. Cusing. 1980. The river continuum concept. Can. J. Fish. Aquat. Sci. 37:130-137.

Weber, C. I. (ed.). 1973. Biological field and laboratory methods for measuring the quality of surface waters and effluents. EPA 670/4-73-001. National Environmental Research Center, U.S. Environmental Protection Agency, Cincinnati, Ohio.

Weber, C. I., W. H. Peltier, T. J. Norberg-King, W. B. Horning II, F. A. Kessler, J. R. Menkedick, T. W. Neiheisel, P. A. Lewis, D. J. Klemm, Q. H. Pickering, E. L. Robinson, J. M. Lazorchak, L. J. Wymer, and R. W. Freyberg. 1989. Shortterm methods for estimating the chronic toxicity of effluents and receiving waters to freshwater organisms. 2nd ed. EPA/600/4-89/001. U.S. Environmental Protection Agency, Cincinnati, Ohio.

Wiederholm, T. 1984. Responses of aquatic insects to environmental pollution. pp. 508-557. In V. H. Resh and D. M. Rosenberg (eds.), The Ecology of Aquatic Insects. Praeger Publishers, New York.

Wojtowicz, J. A. and J. G. Smith. 1992. Biological Monitoring and Abatement Program (BMAP) Benthic Macroinvertebrate Monitoring Project Sample Processing QA Plan. QAP-X-91-ES-068. Oak Ridge National Laboratory, Oak Ridge, Tennessee. 
Appendix A WATER QUALITY DATA FOR BEAR CREEK 





Table A1. Concentrations of nonradiological water quality parameters [mean (minimum maximum)] measured in Bear Creek at kilometers 11.97 and 12.4 in 1990

\begin{tabular}{|c|c|c|c|}
\hline \multirow[b]{2}{*}{ Parameter } & \multirow[b]{2}{*}{ Reference value ${ }^{a}$} & BCK 11.97 & \multirow[t]{2}{*}{ BCK 12.4} \\
\hline & & Concentration $^{b}$ & \\
\hline Arsenic & 0.360 & $<0.007(<0.001-<0.040)$ & $<0.007(<0.001-<0.040)$ \\
\hline Cadmium & 0.004 & $<0.0064(<0.0001-0.0300)$ & $<0.0013(<0.0001-0.021)$ \\
\hline Chromium & 0.016 & $<0.0044(<0.0010-0.0480)$ & $<0.002(<0.001-0.007)$ \\
\hline Cyanide & 0.022 & $<0.006(<0.002-0.034)$ & $<0.005(<0.002-0.011)$ \\
\hline Lead & 0.082 & $<0.002(<0.001-<0.020)$ & $<0.002(<0.001-<0.020)$ \\
\hline Mercury & 0.00015 & $<0.0002(<0.0002-0.0009)$ & $<0.0003(<0.0002-0.0012)$ \\
\hline Nitrate (as N) & NA & $150.1(7.8-860.0)$ & $31.4(2.7-88.0)$ \\
\hline Dissolved oxygen & $3^{c}$ & $9.5(7.0-12.1)$ & $8.4(6.1-11.4)$ \\
\hline Phenols & NiA & $<0.002(<0.001-0.006)$ & $<0.002(<0.001-0.007)$ \\
\hline Total dissolved solids & $\mathrm{NA}$ & $1318(330-3000)$ & $773(260-1300)$ \\
\hline Total suspended solids & NA & $<13(<5-120)$ & $<8(<5-100)$ \\
\hline Selenium & 0.02 & $<0.002(<0.0004-<0.002)$ & $<0.0019(<0.0004-<0.0020)$ \\
\hline Thallium & NA & $<0.001(<0.001-<0.005)$ & $<0.001(<0.001-<0.001)$ \\
\hline $\mathrm{pH}$, standard units & $6-9^{d}$ & $6.9-8.3$ & $6.8-8.0$ \\
\hline Aluminum & NA & $<0.54(<0.04-5.77)$ & $<0.41(<0.01-3.79)$ \\
\hline Barium & NA & $0.481(0.110-1060)$ & $0.0764(0.0393-0.1420)$ \\
\hline Beryllium & 0.013 & $<0.0002(<0.0001-<0.0005)$ & $<0.0002(<0.0001-<0.0004)$ \\
\hline Boron & NA & $0.050(0.011-0.183)$ & $0.063(0.018-0.107)$ \\
\hline Calcium & NA & $242(57-439)$ & $172.0(40.1-310.0)$ \\
\hline Cerium & NA & $<0.02(<0.02-<0.02)$ & $<0.02(<0.02-<0.02)$ \\
\hline Cobalt & NA & $<0.003(<0.002-<0.010)$ & $<0.002(<0.002-0.003)$ \\
\hline Copper & 0.018 & $<0.004(<0.002-<0.010)$ & $<0.003(<0.002-0.006)$ \\
\hline Gallium & NA & $<0.01(<0.01-<0.02)$ & $<0.01(<0.01-<0.02)^{\prime}$ \\
\hline Iron & NA & $<0.39(<0.02-6.31)$ & $<0.30(<0.02-4.41)$ \\
\hline Lanthanum & NA & $<0.003(<0.003-<0.003)$ & $<0.003(<0.003-<0.003)$ \\
\hline Lithium & $\mathrm{NA}$ & $<0.011(<0.001-0.030)$ & \% $66 \%$ \% \\
\hline Magnesium & NA & $33.5(8.8-61.8)$ & $24.5(6.0-49.7)$ \\
\hline Manganese & NA & $1.726(0.367-3.900)$ & $0.073(0.026-0.150)$ \\
\hline Molybdenum & NA & $<0.006(<0.006-<0.030)$ & $<0.006(<0.006-<0.006)$ \\
\hline Nickel & 1.4 & $0.044(0.009-0.222)$ & $<0.012(<0.007-0.238)$ \\
\hline Niobium & NA & $<0.01(<0.01-<0.05)$ & $<0.01(<0.01-<0.01)$ \\
\hline Phosphorus & NA & $<0.11(<0.05-0.60)$ & $<$ \%) \\
\hline Potassium & NA & $5.0(2.2-8.6)$ & $5.5(2.4-10.3)$ \\
\hline Scandium & NA & $<0.0005(<0.0004-<0.0020)$ & $<0.0004(<0.0004-0.001)$ \\
\hline Silver & 0.004 & $<0.005(<0.004-<0.020)$ & $<0.005(<0.004-0.008)$ \\
\hline Sodium & NA & $37.6(10.2-76.5)$ & $6 / 1 \%(1 \%)$ \\
\hline Strontium & NA & $0.714(0.176-1.370)$ & $0.422(0.121-0.773)$ \\
\hline Thorium & $\mathrm{NA}$ & $<0.01(<0.01-<0.05)$ & $<0.01(<0.01-<0.01)$ \\
\hline Titanium & NA & $<0.009(<0.002-0.080)$ & $<0.008(<0.002-0.046)$ \\
\hline Uranium (total) & $\mathrm{NA}$ & $0.211(0.015-0.540)$ & $0.512(0.025-0.870)$ \\
\hline Vanadium & $\mathrm{NA}$ & $<0.004(<0.004-0.020)$ & $<0.004(<0.004-0.009)$ \\
\hline Zinc & 0.117 & $<0.010(<0.001-0.042)$ & $<0.013(<0.001-0.077)$ \\
\hline Zirconium & $\mathrm{NA}$ & $<0.005(<0.002-<0.010)$ & $<0.004(<0.002-<0.010)$ \\
\hline PCB, total & 0.000001 & $<0.0006(<0.0005-<0.0050)$ & $<0.0005(<0.0005-<0.0005)$ \\
\hline Volatile organics, total & 544 & $<0.012(<0.010-0.098)$ & $<0.011(<0.010-0.048)$ \\
\hline
\end{tabular}

Note: $\mathrm{BCK}=$ Bear Creek kilometer. $\mathrm{NA}=$ not applicable. Table compiled from data contained in Tables 3.1 and 3.2 in Kornegay et al. 1991. Oak Ridge Reservation Environmental Report for 1990. Volume 1: Narrative, Summary and Conclusions. ES/ESH-18/V1. Oak Ridge Y-12 Plant. Oak Ridge, Tenn. Shading indicates questionable values for which the mean is outside the stated range, or the mean has a " $<$ " prefix, while no " $<$ " prefixes are associated with range values. Where $\geq 50 \%$ of the observations had a " $<$ " qualifier, a " $<$ " qualifier was included in the value for the mean.

aTennessee Water Quality Criteria.

${ }^{b}$ All units in $\mathrm{mg} / \mathrm{L}$ unless otherwise noted.

Minimum value.

${ }^{d}$ Range. 
Table A.2. Concentrations of nonradiological water quality parameters [mean (minimum maximum)] measured in Bear Creek at kilometers 11.97 and 12.4 in 1991

\begin{tabular}{|c|c|c|c|}
\hline \multirow[b]{2}{*}{ Parameter } & \multirow[b]{2}{*}{ Reference value $^{a}$} & BCK 11.97 & BCK 12.4 \\
\hline & & Concentration $^{b}$ & Concentration $^{b}$ \\
\hline Arsenic & 0.360 & Not reported & $<0.005(<0.001-<0.005)$ \\
\hline Cadmium & 0.004 & $0.0083(0.0005-0.062)$ & $<0.0015(<0.0005-0.022)$ \\
\hline Chromium & 0.016 & $0.002(0.001-0.005)$ & $<0.002(<0.001-0.021)$ \\
\hline Cyanide & 0.022 & $<0.002(<0.002-0.003)$ & $<0.002(<0.002-0.003)$ \\
\hline Lead & 0.082 & $<0.001(<0.001-<0.005)$ & $<0.003(<0.001-<0.058)$ \\
\hline Mercury & 0.00015 & $<0.0004(<0.0002-0.0056)$ & Not reported \\
\hline Nitrate (as $\mathbf{N}$ ) & NA & $159(38-600)$ & $45.6(6.8-530)$ \\
\hline Dissolved oxygen & $3^{c}$ & $9.1(6.8-12.2)$ & $7.5(5.3-11.2)$ \\
\hline Phenols & NA & $<0.002(<0.001-0.006)$ & $0.0021(0.0001-0.007)$ \\
\hline Total dissolved solids & NA & $1305(270-2300)$ & $860(260-1100)$ \\
\hline Total suspended solids & NA & $<6(<5-36)$ & $15.9(0.5-380)$ \\
\hline Selenium & 0.02 & $<0.002(<0.002-<0.002)$ & $<0.002(<0.002-<0.002)$ \\
\hline Thallium & NA & $<0.001(<0.001-<0.005)$ & $<0.001(<0.001-<0.005)$ \\
\hline $\mathrm{pH}$, standard units & $6-9^{d}$ & $6.7-8.8$ & $7.3-7.8$ \\
\hline Aluminum & $\mathrm{NA}$ & $<0.22(<0.04-0.89)$ & $<0.69(<0.04-21.8)$ \\
\hline Barium & NA & $0.49(0.17-1.16)$ & $0.109(0.0499-0.928)$ \\
\hline Beryllium & 0.013 & $<0.0004(<0.0004-<0.002)$ & $<0.0005(<0.0004-<0.002)$ \\
\hline Boron & NA & $0.094(0.036-0.289)$ & $0.092(0.05-0.291)$ \\
\hline Calcium & NA & $238.9(96.6-420)$ & $172.9(57.2-230)$ \\
\hline Cerium & NA & $<0.02(<0.02-<0.08)$ & $<0.02(<0.02-<0.08)$ \\
\hline Cobalt & NA & $<0.003(<0.002-0.01)$ & $<0.003(<0.002-0.014)$ \\
\hline Copper & 0.018 & $0.007(0.006-0.03)$ & $<0.009(<0.006-0.052)$ \\
\hline Gallium & NA & $<0.02(<0.02-<0.09)$ & $<0.02(<0.02-<0.09)$ \\
\hline Iron & NA & $<0.13(<0.06-0.66)$ & $<1.08(<0.06-42.6)$ \\
\hline Lithium & ivA & $<0.02(<0.02-<0.08)$ & $<0.02(<0.02-<0.08)$ \\
\hline Magnesium & NA & $32.6(13.0-59.8)$ & $24.63(8.12-37.4)$ \\
\hline Manganese & NA & $1.453(0.101-3.78)$ & $0.058(0.009-0.571)$ \\
\hline Molybdenum & NA & $<0.006(<0.006-<0.03)$ & $<0.007(<0.006-<0.03)$ \\
\hline Nickel & 1.4 & $0.038(0.009-0.10)$ & $<0.01(<0.008-0.04)$ \\
\hline Niobium & NA & $<0.01(<0.01-<0.05)$ & $<0.01(<0.01-<0.05)$ \\
\hline Phosphorus & $\mathrm{NA}$ & $<0.06(<0.05-0.2)$ & $<0.08(<0.05-0.4)$ \\
\hline Potassium & NA & $4.9(2.9-7.4)$ & $5.4(3.8-7.5)$ \\
\hline Scandium & NA & $<0.000(<0.000-<0.002)$ & $<0.0007(<0.0004-0.0115)$ \\
\hline Silver & 0.004 & $<0.006(<0.006-<0.03)$ & $<0.007(<0.006-<0.03)$ \\
\hline Sodium & NA & $41.4(20.5-67.8)$ & $61.0(18.6-179)$ \\
\hline Strontium & NA & $0.70(0.29-1.26)$ & $0.440(0.155-0.578)$ \\
\hline Thorium & NA & $<0.01(<0.01-0.05)$ & $<0.01(<0.01-0.05)$ \\
\hline Titanium & NA & $<0.01(<0.01-<0.06)$ & $<0.02(<0.01-0.19)$ \\
\hline Uranium (total) & NA & $0.224(0.20-0.73)$ & $0.64(0.129-1.04)$ \\
\hline Vanadium & NA & $<0.004(<0.004-<0.02)$ & $<0.006(<0.004-0.09)$ \\
\hline Zinc & 0.117 & $0.011(<0.007-0.05)$ & $0.018(<0.007-0.2)$ \\
\hline Zirconium & NA & $<0.005(<0.004-<0.02)$ & $<0.006(<0.004-<0.05)$ \\
\hline PCB, total & 0.000001 & $<0.0005(<0.0005-<0.0005)$ & $<0.0005(<0.0005-<0.0005)$ \\
\hline Volatile organics, total & 544 & $<0.01(<0.01-0.01)$ & $<0.01(<0.01-<0.01)$ \\
\hline
\end{tabular}

Note: $\mathrm{BCK}=$ Bear Creek kilometer. NA = not applicable. Table compiled from data contained in Tables 4.1 and 4.2 in Kornegay et al. 1992. Oak Ridge Reservation Environmental Report for 1991. Volume 2: Data Presentation. ES/ESH-22/V2. Oak Ridge Y-12 Plant. Oak Ridge, Tenn. Where $\geq 50 \%$ of the observations had a " $<$ " qualifier, a " $<$ " qualifier was included in the value for the mean. Where $\geq 50 \%$ of the observations had a " $<$ " qualifier, a " $<$ " quailifier was included in the value for the mean.

"Tennessee Water Quality Criteria.

${ }^{b}$ All units in $\mathrm{mg} / \mathrm{L}$ unless otherwise noted.

Minimum value.

${ }^{d}$ Range. 
Table A.3. Concentrations of nonradiological water quality parameters [mean (minimum maximum)] measured in Bear Creek at kilometers 11.97 and 12.4 in 1992

\begin{tabular}{|c|c|c|c|c|c|}
\hline \multirow[b]{2}{*}{ Parameter } & \multirow[b]{2}{*}{$\begin{array}{c}\text { Reference } \\
\text { value }^{\alpha}\end{array}$} & \multicolumn{2}{|l|}{ BCK 11.97} & \multicolumn{2}{|l|}{ BCK 124} \\
\hline & & Concentration $^{b}$ & $\begin{array}{l}\text { No. of values } \\
\text { exceeding } \\
\text { reference }\end{array}$ & Concentration $^{b}$ & $\begin{array}{l}\text { No. of values } \\
\text { exceeding } \\
\text { reference }\end{array}$ \\
\hline Arsenic & 0.360 & $<0.005(<0.005-<0.005)$ & 0 & $<0.005(<0.005-<0.005)$ & 0 \\
\hline Cadmium & 0.004 & $<0.008(<0.0003-0.135)$ & $27^{c}$ & $<0.001(<0.0003-0.011)$ & $1^{c}$ \\
\hline Chromium & 0.016 & $<0.002(<0.001-0.013)$ & 0 & $<0.002(<0.001-0.011)$ & 0 \\
\hline Cyanide & 0.022 & $<0.002(<0.002-0.017)$ & 0 & $<0.002(<0.002-<0.007)$ & 0 \\
\hline Lead & 0.082 & $<0.0029(<0.0004-<0.01)$ & 0 & $<0.003(<0.0006-0.02)$ & 0 \\
\hline Mercury & 0.00015 & $<0.0002(<0.0002-0.001)$ & $52^{d}$ & $<0.0002(<0.0002-0.001)$ & $52^{4}$ \\
\hline Nitrate (as N) & NA & $122(14-320)$ & NA & $24.3(2.4-43)$ & NA \\
\hline Dissolved oxygen & $3^{*}$ & $9.6(6.4-14.1)$ & 0 & $6.9(4.6-10.2)$ & 0 \\
\hline Phenols & NA & $<0.002(<0.001-0.008)$ & NA & $<0.002(<0.001-0.004)$ & NA \\
\hline Total dissolved & NA & $1168(120-3000)$ & NA & $736(76-1900)$ & NA \\
\hline Total suspended & NA & $<6(<5-23)$ & NA & $<5.9(<5-21)$ & NA \\
\hline Selenium & 0.02 & $<0.002(<0.002-0.002)$ & 0 & $<0.002(<0.002-<0.002)$ & 0 \\
\hline Thallium & NA & $<0.001(<0.001-<0.005)$ & NA & $<0.002(<0.001-0.05)$ & NA. \\
\hline $\mathrm{pH}$, standard units & $6-9$ & $6.9-8.2$ & 0 & $6.7-8.7$ & 0 \\
\hline Aluminum & NA & $0.17(0.04-1.84)$ & NA & $<0.12(<0.04-0.98)$ & NA \\
\hline Barium & NA & $<0.417(<0.088-1.01)$ & NA & $<0.084(<0.018-0.496)$ & 0 \\
\hline Beryllium & 0.013 & $<0.0004(<0.0004-<0.004)$ & 0 & $<0.0004(<0.0004-<0.0004)$ & NA \\
\hline Boron & NA & $0.065(0.027-0.166)$ & NA & $0.084(0.021-0.141)$ & NA \\
\hline Calcium & NA & $<215.2(<48.7-454)$ & NA & $153.3(21.8-293)$ & NA \\
\hline Cerium & NA & $<0.02(<0.02-<0.02)$ & $\mathrm{NA}$ & $<0.02(<0.02-<0.02)$ & $\mathrm{NA}$ \\
\hline Cobalt & NA & $<0.003(<0.002-0.007)$ & NA & $<0.002(<0.002-<0.002)$ & NA \\
\hline Copper & 0.018 & $<0.006(<0.006-0.007)$ & 0 & $<0.006(<0.006-<0.006)$ & 0 \\
\hline Gallium & NA & $<0.02(<0.02-<0.02)$ & NA & $<0.02(<0.02-<0.02)$ & NA \\
\hline Iron & NA & $<0.13(<0.06-1.97)$ & NA & $<0.13(<0.06-1.25)$ & NA \\
\hline Lithium & NA & $<0.02(<0.02-<0.02)$ & NA & $<0.02(<0.02-0.02)$ & NA \\
\hline Magnesium & NA & $29.7(6.5-58.9)$ & NA & $21.75(2.93-43.1)$ & NA \\
\hline Manganese & NA & $1.111(0.012-3.24)$ & NA & $0.027(0.005-0.328)$ & NA \\
\hline Molybdenum & NA & $<0.006(<0.006-<0.006)$ & NA & $<0.006(<0.006-<0.006)$ & NA \\
\hline Nickel & 1.4 & $<0.029(<0.008-0.08)$ & 0 & $<0.008(<0.008-<0.025)$ & 0 \\
\hline Niobium & NA & $<0.01(<0.01-<0.01)$ & NA & $<0.01(<0.01-<0.01)$ & NA \\
\hline Phosphorus & NA & $<0.05(<0.05-<0.05)$ & NA & $<0.05(<0.05-<0.09)$ & NA \\
\hline Potassium & NA & $4.6(21-8.1)$ & NA & $4.9(2.5-8.4)$ & NA \\
\hline Scandium & NA & $<0.0004(<0.0004-0.0005)$ & NA & $<0.0004(<0.0004-0.0004)$ & NA \\
\hline Silver & 0.004 & $<0.006(<0.006-<0.006)$ & $52^{d}$ & $<0.006(<0.006-<0.006)$ & $52^{d}$ \\
\hline Sodium & NA & $37.7(12.6-59.8)$ & NA & $48.6(1.9-75.9)$ & NA \\
\hline Strontium & NA & $0.644(0.143-1.27)$ & NA & $0.409(0.043-0.911)$ & NA \\
\hline Thorium & NA & $<0.01(<0.01-0.01)$ & NA & $<0.01(<0.01-0.01)$ & NA \\
\hline Titanium & $\mathrm{NA}$ & $<0.01(<0.01-0.02)$ & NA & $<0.02(<0.01-0.02)$ & NA \\
\hline Uranium (total) & NA & $<0.22(<0.055-0.752)$ & $\mathrm{NA}$ & $0.571(0.017-0.844)$ & NA \\
\hline Vanadium & $\mathrm{NA}$ & $<0.004(<0.004-<0.004)$ & NA & $<0.004(<0.004-<0.004)$ & NA \\
\hline Zinc & 0.117 & $0.01(<0.01-0.02)$ & 0 & $<0.01(<0.01-0.04)$ & 0 \\
\hline Zirconium & NA & $<0.004(<0.004-<0.01)$ & $\mathrm{NA}$ & $<0.004(<0.004-<0.01)$ & $\mathrm{NA}$ \\
\hline PCB, total & 0.001 & $<0.5(<0.5-<0.5)$ & $52^{d}$ & $<0.6(<0.5-<5.0)$ & $52^{4}$ \\
\hline Volatile organics, & 544 & $<0.01(<0.01-<0.01)$ & 0 & $<0.01(<0.01-<0.01)$ & 0 \\
\hline
\end{tabular}

Note: $\mathrm{BCK}=\mathrm{Bear}$ Creek kilometer. NA $=$ not applicable. Table compiled from data contained in Tables 4.1 and 4.3 in Kornegay et al. 1993. Oak Ridge Reservation Environmental Report for 1992. Volume 2: Data Presentation.

ES/ESH-31/N2. Oak Ridge Y-12 Plant. Oak Ridge, Tenn.

"Tennessee Water Quality Criteria.

${ }^{b}$ All units in $\mathrm{mg} / \mathrm{L}$ unless otherwise noted.

${ }^{c}$ Reference value represent the dissolved form of this metal only. The actual data are representative of all forms.

${ }^{d}$ The analytical detection limit for this parameter is higher than the reference value.

Minimum value.

Range. 
Table A4. Concentrations of nonradiological water quality parameters [mean (minimum maximum)] measured in Bear Creek at kilometers 11.97 and 12.4 in 1993

\begin{tabular}{|c|c|c|c|c|c|}
\hline \multirow[b]{2}{*}{ Parameter } & \multirow[b]{2}{*}{$\begin{array}{l}\text { Reference } \\
\text { value }\end{array}$} & \multicolumn{2}{|c|}{ BCK 11.97} & \multicolumn{2}{|l|}{ BCK 124} \\
\hline & & Concentration ${ }^{b}$ & $\begin{array}{l}\text { No. of values } \\
\text { exceeding } \\
\text { reference }\end{array}$ & Concentration ${ }^{8}$ & $\begin{array}{l}\text { No. of values } \\
\text { exceeding } \\
\text { reference }\end{array}$ \\
\hline Arsenic & 0.360 & $<0.1(<0.005-<0.2)$ & 0 & $<0.1(<0.005-<0.2)$ & 0 \\
\hline Cadmium & 0.004 & $<0.01(<0.0005-0.02)$ & $33^{c, d}$ & $<0.001(<0.0003-<0.02)$ & $19^{c o d}$ \\
\hline Chromium & 0.016 & $<0.01(<0.001-0.03)$ & $21^{d, e}$ & $<0.01(<0.001-0.03)$ & $21^{\alpha, e}$ \\
\hline Cyanide & 0.022 & $<0.01(<0.002-<0.2)$ & $1^{\alpha}$ & $<0.01(<0.002-0.02)$ & 0 \\
\hline Lead & $0.08 ?$ & $<0.04(<0.004-<0.1)$ & $19^{c, 4}$ & $<0.04(<0.004-0.1)$ & $19 c d$ \\
\hline Mercury & 0.00015 & $<0.0002(<0.0002-0.0003)$ & $5 Z^{d}$ & $<0.0002(<0.0002-0.0004)$ & $50^{4}$ \\
\hline Nitrate (as N) & $\mathrm{NA}$ & $91(17-230)$ & NA & $18(4.2-35)$ & NA \\
\hline Dissolved oxygen & 3 & $9.8(6.7-15.2)$ & 0 & $7.3(4.9-12.3)$ & 0 \\
\hline Phenols & NA & $<0.003(<0.001-<0.005)$ & NA & $<0.003(<0.001-0.005)$ & NA \\
\hline Total dissolved solids & NA & $1200(530-2600)$ & $\mathbf{N A}$ & $960(510-1400)$ & NA \\
\hline Total suspended solids & NA & $<16(<5-410)$ & $\mathbf{N A}$ & $<13(<5-290)$ & NA \\
\hline Selenium & 0.02 & $<0.2(<0.002-<0.5)$ & $22^{d}$ & $<0.2(<0.002-0.5)$ & $22^{d}$ \\
\hline Thallium & NA & $<0.1(<0.001-<0.2)$ & NA & $<0.1(<0.001-<0.2)$ & $N A$ \\
\hline $\mathrm{pH}$, standard units & $6-98$ & $7.4-8.3$ & 0 & $701-7.9$ & 0 \\
\hline Aluminum & NA & $<0.3(<0.04-0.7)$ & NA & $<0.3(<0.04-1.8)$ & NA \\
\hline Barium & NA & $0.3(0.112-0.6)$ & NA & $0.092(0.058-0.12)$ & NA \\
\hline Beryllium & 0.013 & $<0.001(<0.0004-<0.002)$ & $20^{d}$ & $<0.001(<0.0004-<0.002)$ & $20^{4}$ \\
\hline Boron & NA & $0.1(0.026-0.2)$ & NA & $0.073(0.027-0.11)$ & NA \\
\hline Calcium & NA & $195(68.1-334)$ & $\mathbf{N A}$ & $160(95.8-200)$ & NA \\
\hline Cerium & NA & $<0.04(<0.02-<0.1)$ & NA & $<0.04(<0.02-<0.08)$ & $\mathbf{N A}$ \\
\hline Cobalt & NA & $<0.01(<0.002-0.01)$ & NA & $<0.01(<0.002-<0.01)$ & NA \\
\hline Copper & 0.018 & $<0.02(<0.006-<0.03)$ & $20^{<.4}$ & $<0.02(<0.006<<0.03)$ & $20^{=\alpha}$ \\
\hline Gallium & NA & $<0.05(<0.02-<0.1)$ & $\mathrm{NA}$ & $<0.05(<0.02-<0.09)$ & NA \\
\hline Iron & NA & $<0.3(<0.06-0.9)$ & NA & $<0.4(<0.06-3.2)$ & NA \\
\hline Lithium & NA & $<0.04(<0.02-<0.1)$ & NA & $<0.04(<0.02-0.08)$ & $\mathrm{NA}$ \\
\hline Magnesium & NA & $26.3(9.58-50.2)$ & $\mathrm{NA}$ & $21(11.9-27)$ & NA \\
\hline Manganese & NA & $0.8(0.02-2.3)$ & NA & $0.02(0.01-0.109)$ & NA \\
\hline Molybdenum & NA & $<0.02(<0.006-<0.03)$ & NA & $<0.02(<0.006-<0.03)$ & NA \\
\hline Nickel & 1.4 & $<0.03(<0.008-0.1)$ & 0 & $<0.02(<0.008-<0.04)$ & 0 \\
\hline Niobium & NA & $<0.03(<0.01-<0.1)$ & NA & $<0.03(<0.01-0.05)$ & NA \\
\hline Phosphorus & NA & $<0.1(<0.05-0.3)$ & NA & $<0.1(<0.05-0.3)$ & NA \\
\hline Potassium & $\mathrm{NA}$ & $<4.4(<23-7.5)$ & NA & $5(3-6)$ & NA \\
\hline Silver & 0.004 & $<0.015(<0.006-<0.03)$ & $52^{c, 4}$ & $<0.02(<0.006-<0.03)$ & $52^{c, d}$ \\
\hline Sodium & NA & $49.8(22.5-154)$ & NA & $100(51.5-351)$ & NA \\
\hline Strontium & NA & $0.57(0.22-1.1)$ & NA & $0.42(0.27-0.503)$ & NA \\
\hline Thorium & NA & $<0.03(<0.01-<0.05)$ & NA & $<0.03(<0.01-<0.05)$ & NA \\
\hline Titanium & NA & $<0.04(<0.02-<0.1)$ & NA & $<0.04(<0.02-<0.06)$ & NA \\
\hline Uranium (total) ${ }^{n}$ & NA & $0.37(0.32-0.63)$ & NA & $0.58(0.272-0.91)$ & NA \\
\hline Vanadium & NA & $<0.01(<0.004-<0.02)$ & NA & $<0.01(<0.004-<0.02)$ & NA \\
\hline Zinc & 0.117 & $<0.03(<0.01-<0.05)$ & 0 & $<0.03(<0.01-0.05)$ & 0 \\
\hline Zirconium & NA & $<0.01(<0.004-<0.02)$ & NA & $<0.01(<0.004-<0.02)$ & NA \\
\hline PCB, total & 0.001 & $<0.5($ all $<0.5)$ & $52^{4}$ & $<0.6(<0.5-<6.0)$ & $50^{\circ}$ \\
\hline Volatile organics, total & 544 & $<0.01(<0.01-<0.01)$ & 0 & $<0.01(<0.01-<0.01)$ & 0 \\
\hline
\end{tabular}

Note: $\mathrm{BCK}=$ Bear Creek kilometer. NA = not applicable. Provisional data provided by Compliance Monitoring Services, Oak Ridge Y-12 Plant. Where $\geq 50 \%$ of the observations had a " $<$ " qualifier, a " $<$ " qualifier was included in the value for the mean.

Tennessee Water Quality Criteria.

${ }^{b} \mathrm{All}$ units in $\mathrm{mg} / \mathrm{L}$ unless otherwise noted.

'Reference value represent the dissolved form of this metal only. The actual data are representative of all forms.

The analytical detection limit for this parameter is higher than the reference value.

This limit applies to hexavalent Chromium only. The data represent total Chromium.

Minimum value.

sRange.

${ }^{h}$ Medium (min-max). 
Table A.5. Concentrations of nonradiological water quality parameters [mean (minimum maximum)] measured in Bear Creek at kilometers 11.97 and 12.4 in January through June 1994

\begin{tabular}{|c|c|c|c|}
\hline \multirow[b]{2}{*}{ Parameter } & \multirow[b]{2}{*}{ Reference value $^{a}$} & BCK 11.97 & BCK 12.4 \\
\hline & & Concentration $^{b}$ & Concentration $^{b}$ \\
\hline Arsenic & 0.360 & $<0.2(<0.04-<0.2)$ & $<0.2(<0.04-<0.2)$ \\
\hline Cadmium & 0.004 & $<0.02(<0.004-<0.02)$ & $<0.02(<0.004-<0.02)$ \\
\hline Chromium & 0.016 & $<0.03(<0.006-<0.03)$ & $<0.03(<0.006-<0.03)$ \\
\hline Cyanide & 0.022 & $<0.01(<0.01-<0.01)$ & $<0.01(<0.01-<0.01)$ \\
\hline Lead & 0.082 & $<0.1(<0.02-<0.1)$ & $<0.01(<0.002-<0.1)$ \\
\hline Mercury & 0.00015 & $<0.0002(<0.0002-0.0005)$ & $<0.0003(<0.0002-<0.0008)$ \\
\hline Nitrate (as N) & NA & $47(3.0-94)$ & $11.3(0.76-24)$ \\
\hline Dissolved oxygen & $3^{c}$ & $9.8(5.8-13.3)$ & $8.2(5.6-11.5)$ \\
\hline Phenols & NA & $<0.005(<0.005-0.006)$ & $<0.005(<0.005-<0.005)$ \\
\hline Total dissolved solids & NA & $784(220-1500)$ & $955(440-1400)$ \\
\hline Total suspended solids & NA & $<7(<5-23)$ & $<6.3(<5-15)$ \\
\hline Selenium & 0.02 & $<0.5(<0.1-<0.5)$ & $<0.5(<0.1-<0.5)$ \\
\hline Thallium & $\mathrm{NA}$ & $\% / 4 \% 1 \%$ & $<0.2(<0.03-<0.2)$ \\
\hline $\mathrm{pH}$, standard units & $6-9^{d}$ & $7.1-8.2$ & $7.2-7.9$ \\
\hline Aluminum & NA. & $<0.4(<0.2-1.4)$ & $<0.2(<0.07-0.9)$ \\
\hline Barium & NA & $0.24(0.041-0.454)$ & $0.095(0.042-0.123)$ \\
\hline Beryllium & 0.013 & $<0.002(<0.0004-<0.002)$ & $<0.002(<0.0004-<0.002)$ \\
\hline Boron & NA & $<0.04(<0.028-0.08)$ & $<0.05(<0.03-0.08)$ \\
\hline Calcium & NA & $143(24.3-251)$ & $147(40.7-193)$ \\
\hline Cerium & NA & $<0.08(<0.02-<0.08)$ & $<0.08(<0.02-0.08)$ \\
\hline Cobalt &  & $<0.01(<0.002-0.01)$ & $<0.01(<0.002-<0.01)$ \\
\hline Copper & 0.018 & $<0.03(<0.006-<0.03)$ & -10\%86/ \\
\hline Gallium & NA & $<0.09(<0.02-<0.09)$ & $<0.09(<0.02-<0.09)$ \\
\hline Iron & NA & $<0.46(<0.24-2.2)$ & $<0.4(<0.07-1.2)$ \\
\hline Lithium & NA & $<0.08(<0.02-<0.08)$ & $<0.08(<0.02-<0.08)$ \\
\hline Magnesium & NA & $18.3(3.4-32.5)$ & $18.4(4.9-24.2)$ \\
\hline Manganese & NA & $0.77(0.116-1.59)$ & $0.024(0.012-0.035)$ \\
\hline Molybdenum & NA & $<0.03(<0.006-<0.03)$ & $<0.03(<0.006-<0.03)$ \\
\hline Nickel & 1.4 & $<0.04(<0.016-0.04)$ & $<0.04(<0.008-0.04)$ \\
\hline Niobium & NA & $<0.05(<0.01-<0.05)$ & $<0.05(<0.01-<0.05)$ \\
\hline Phosphorus & $\mathrm{NA}$ & $<0.3(<0.3-0.3)$ & $<0.3(<0.3-<0.3)$ \\
\hline Potassium & NA & $<3.3(<2.2-5.0)$ & $<4(<3-5)$ \\
\hline Silver & 0.004 & $<0.03(<0.006-<0.03)$ & $<0.03(<0.006-0.03)$ \\
\hline Sodium & NA & $46.7(23.4-101)$ & $139(69.2-323)$ \\
\hline Strontium & $\mathbf{N A}$ & $0.41(0.075-0.72)$ & $0.384(0.114-0.497)$ \\
\hline Thorium & NA & $<0.05(<0.01-<0.05)$ & $<0.05(<0.01-<0.05)$ \\
\hline Titanium & NA & $<0.06(<0.02-<0.06)$ & $<0.06(<0.006-<0.06)$ \\
\hline Uranium (total) $^{e}$ & NA & $0.13(<0.001-0.27)$ & $0.48(0.10-0.61)$ \\
\hline Vanadium & NA & $<0.02(<0.004-<0.02)$ & $<0.02(<0.004-<0.02)$ \\
\hline Zinc & 0.117 & $<0.05(<0.01-<0.05)$ & $<0.05(<0.01-<0.05)$ \\
\hline Zirconium & NA & $0801 \% 10 \% \%$ or & $<0.02(<0.004-<0.02)$ \\
\hline PCB, total & 0.001 & $<0.5(<0.5-<0.5)$ & $<0.5(<0.5-<0.5)$ \\
\hline Volatile organics, total & 544 & $<0.01(<0.01-<0.01)$ & $<0.01(<0.01-0.01)$ \\
\hline
\end{tabular}

Note: BCK $=$ Bear Creek kilometer. NA $=$ not applicable. Provisional data provided by Compliance Monitoring Services, Oak Ridge Y-12 Plant. Oak Ridge, Tenn. Shading indicates questionable values (e.g., for which the mean is outside of the stated range, or the mean has a " $<$ " prefix, while no " $<$ " prefixes are associated with the range values). Where $\geq 50 \%$ of the observations had a " $<$ " qualifier, a " $<$ " qualifier was included in the value for the mean.

Tennessee Water Quality Criteria.

${ }^{s}$ All units in $\mathrm{mg} / \mathrm{L}$ unless otherwise noted.

¿Minimum value.

Range.

Median (min-max). 
Table A6. Monthly mean $\pm 1 \mathrm{SD}$, range (minimum-maximum), and number of days of record of water temperature $(\circ \mathrm{C})$ at four sites in Bear Creek and at two reference sites, Grassy Creek kilometer (GCK) 2.4 and Gum Hollow Creek kilometer (GHK) 2.9, January-December, 1988-93

\begin{tabular}{|c|c|c|c|c|c|c|}
\hline \multirow{2}{*}{\multicolumn{2}{|c|}{ Sample periods }} & \multicolumn{5}{|c|}{ Sites $^{a}$} \\
\hline & & BCK 7.87 & BCK 9.40 & BCK 9.91 & BCK 11.98 & GCK 2.4 \\
\hline \multirow[t]{12}{*}{1988} & Jan. & $\begin{array}{c}3.5 \pm 3.2 \\
(-1.3-10.6) \\
28\end{array}$ & $\begin{array}{c}7.6 \pm 1.6 \\
(0.7-11.6) \\
30\end{array}$ & $\begin{array}{c}3.5 \pm 3.0 \\
(-0.2-10.7) \\
30\end{array}$ & $\begin{array}{c}3.6 \pm 3.0 \\
(0.0-11.4) \\
31\end{array}$ & $\begin{array}{c}3.0 \pm 2.7 \\
(-6.8-4.3) \\
25\end{array}$ \\
\hline & Feb. & $\begin{array}{c}6.4 \pm 2.6 \\
(1.2-12.7) \\
29\end{array}$ & $\begin{array}{c}8.1 \pm 1.8 \\
(3.9-12.6) \\
29\end{array}$ & $\begin{array}{c}5.9 \pm 2.8 \\
(0.7-12.8) \\
29\end{array}$ & $\begin{array}{c}5.8 \pm 3.2 \\
(0.1-14.4) \\
29\end{array}$ & $\begin{array}{c}4.5 \pm 2.4 \\
(0.6-10.1) \\
29\end{array}$ \\
\hline & Mar. & $\begin{array}{c}10.0 \pm 2.9 \\
(3.2-18.3) \\
3 !\end{array}$ & $\begin{array}{c}10.7 \pm 1.8 \\
(6.2-14.7) \\
31\end{array}$ & $\begin{array}{c}10.2 \pm 3.3 \\
(3.1-19.1) \\
31\end{array}$ & $\begin{array}{c}10.2 \pm 3.9 \\
(2.1-21.6) \\
31\end{array}$ & $\begin{array}{c}7.9 \pm 3.9 \\
(-3.6-18.0) \\
31\end{array}$ \\
\hline & Apr. & $\begin{array}{c}13.5 \pm 2.7 \\
(7.4-20.6) \\
30\end{array}$ & $\begin{array}{c}13.1 \pm 1.7 \\
(9.1-17.8) \\
30\end{array}$ & $\begin{array}{c}14.1 \pm 3.1 \\
(7.1-22.3) \\
30\end{array}$ & $\begin{array}{c}14.2 \pm 3.9 \\
(6.2-24.7) \\
30\end{array}$ & $\begin{array}{c}12.4 \pm 2.7 \\
(6.1-19.7) \\
30\end{array}$ \\
\hline & May & $\begin{array}{c}15.6 \pm 2.4 \\
(9.6-20.9) \\
31\end{array}$ & $\begin{array}{c}13.7 \pm 1.1 \\
(11.3-17.8) \\
31\end{array}$ & $\begin{array}{c}16.2 \pm 2.3 \\
(10.4-20.7) \\
31\end{array}$ & $\begin{array}{c}17.6 \pm 4.5 \\
(8.5-27.7) \\
26\end{array}$ & $\begin{array}{c}14.9 \pm 2.8 \\
(7.4-20.9) \\
31\end{array}$ \\
\hline & June & $\begin{array}{c}19.1 \pm 2.7 \\
(11.8-25.3) \\
30\end{array}$ & $\begin{array}{c}14.2 \pm 1.1 \\
(11.7-17.4) \\
30\end{array}$ & $\begin{array}{c}19.2 \pm 2.5 \\
(12.8-24.5) \\
30\end{array}$ & $\mathrm{ND}^{b}$ & $\begin{array}{c}18.3 \pm 3.0 \\
(11.4-25.3) \\
30\end{array}$ \\
\hline & July & $\begin{array}{c}20.8 \pm 1.8 \\
(14.5-24.2) \\
25\end{array}$ & $\begin{array}{c}16.2 \pm 2.1 \\
(12.3-23.5) \\
25\end{array}$ & $\begin{array}{c}20.9 \pm 1.7 \\
(15.8-24.2) \\
25\end{array}$ & ND & $\begin{array}{c}20.8 \pm 2.1 \\
(14.7-25.6) \\
26\end{array}$ \\
\hline & Aug. & ND & $\begin{array}{c}15.4 \pm 1.3 \\
(13.3-22.7) \\
27\end{array}$ & $\begin{array}{c}21.4 \pm 1.6 \\
(17.4-25.2) \\
27\end{array}$ & ND & $\begin{array}{c}21.3 \pm 1.4 \\
(16.8-24.1) \\
26\end{array}$ \\
\hline & Sept. & ND & $\begin{array}{c}15.4 \pm 1.4 \\
(13.3-21.4) \\
30\end{array}$ & $\begin{array}{c}18.9 \pm 1.4 \\
(14.7-22.4) \\
30\end{array}$ & $\mathrm{ND}$ & $\begin{array}{c}18.3 \pm 2.0 \\
(12.7-23.5) \\
30\end{array}$ \\
\hline & Oct. & ND & $\begin{array}{c}12.3 \pm 1.2 \\
(9.8-16.9) \\
31\end{array}$ & $\begin{array}{c}11.2 \pm 3.0 \\
(5.9-18.8) \\
31\end{array}$ & ND & $\begin{array}{c}10.3 \pm 3.7 \\
(2.6-21.4) \\
31\end{array}$ \\
\hline & Nov. & ND & $\begin{array}{c}11.2 \pm 1.3 \\
(7.1-14.0) \\
30\end{array}$ & $\begin{array}{c}9.8 \pm 2.0 \\
(4.9-14.5) \\
30\end{array}$ & ND & $\begin{array}{c}8.8 \pm 2.0 \\
(4.1-13.1) \\
30\end{array}$ \\
\hline & Dec. & ND & $\begin{array}{c}8.7 \pm 1.2 \\
(5.1-11.8) \\
31\end{array}$ & $\begin{array}{c}5.3 \pm 2.5 \\
(0.3-11.8) \\
31\end{array}$ & ND & $\begin{array}{c}3.7 \pm 2.7 \\
(-0.2-10.3) \\
31\end{array}$ \\
\hline
\end{tabular}


Table A6 (continued)

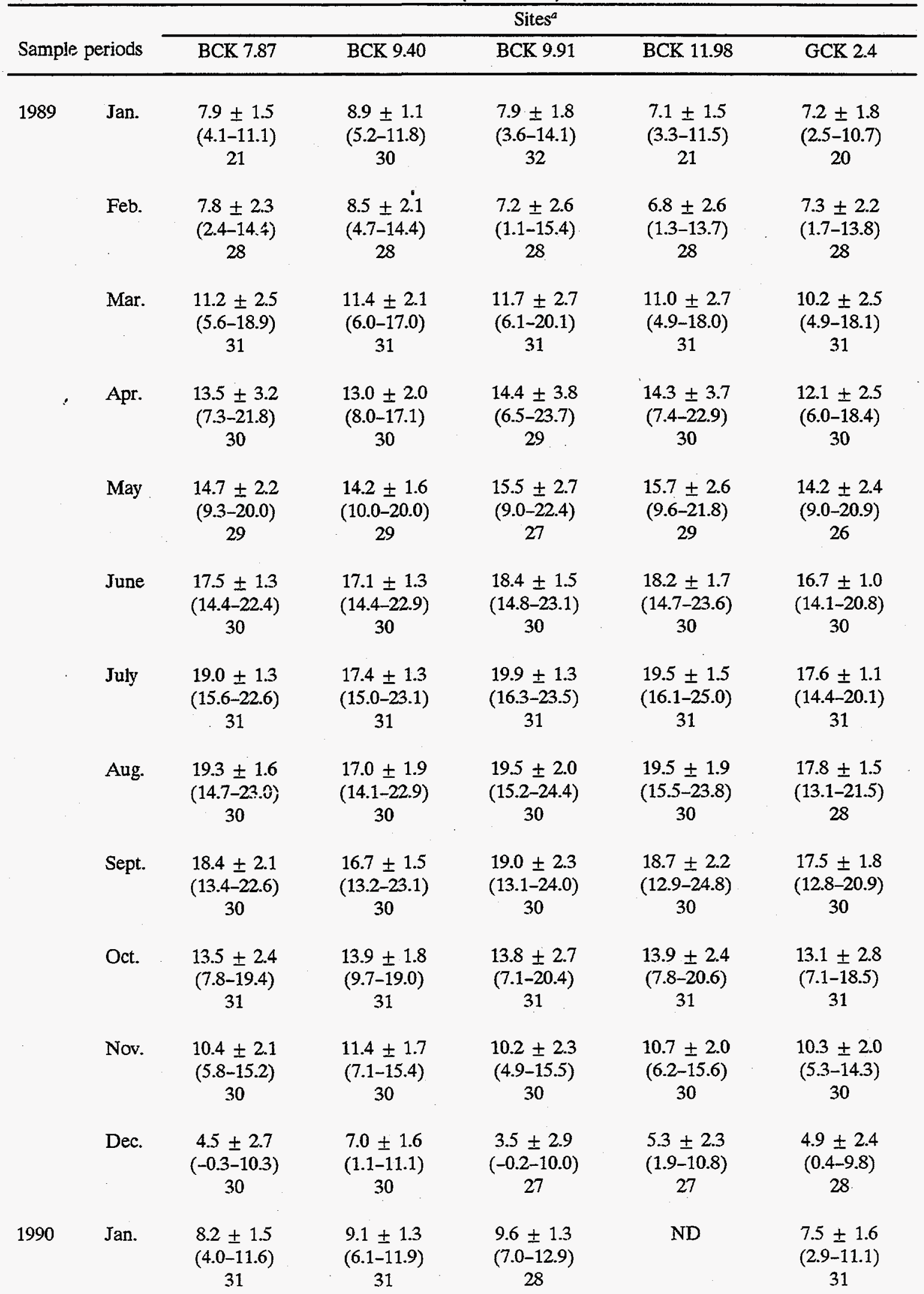


Table A6 (continued)

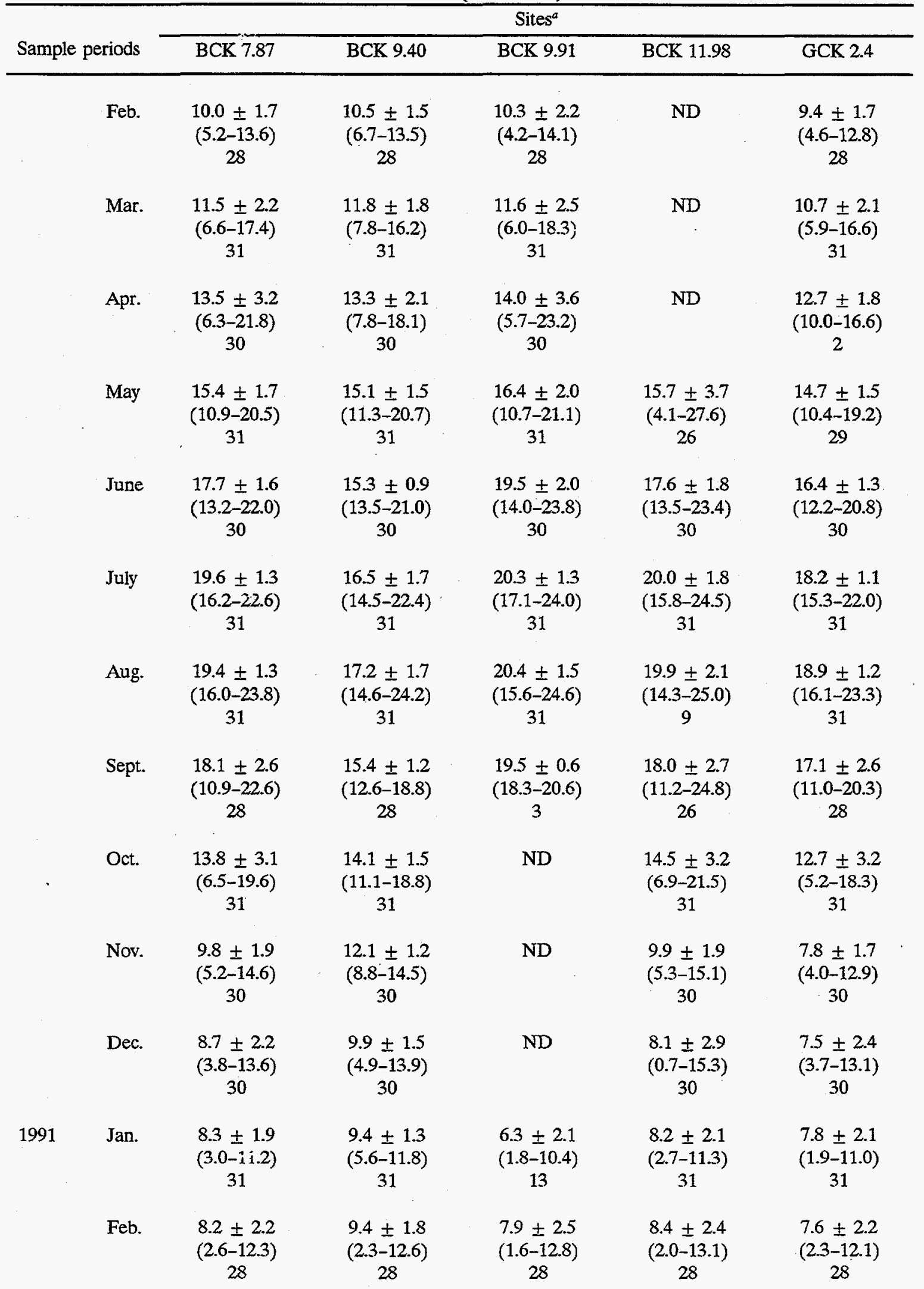


Table A6 (continued)

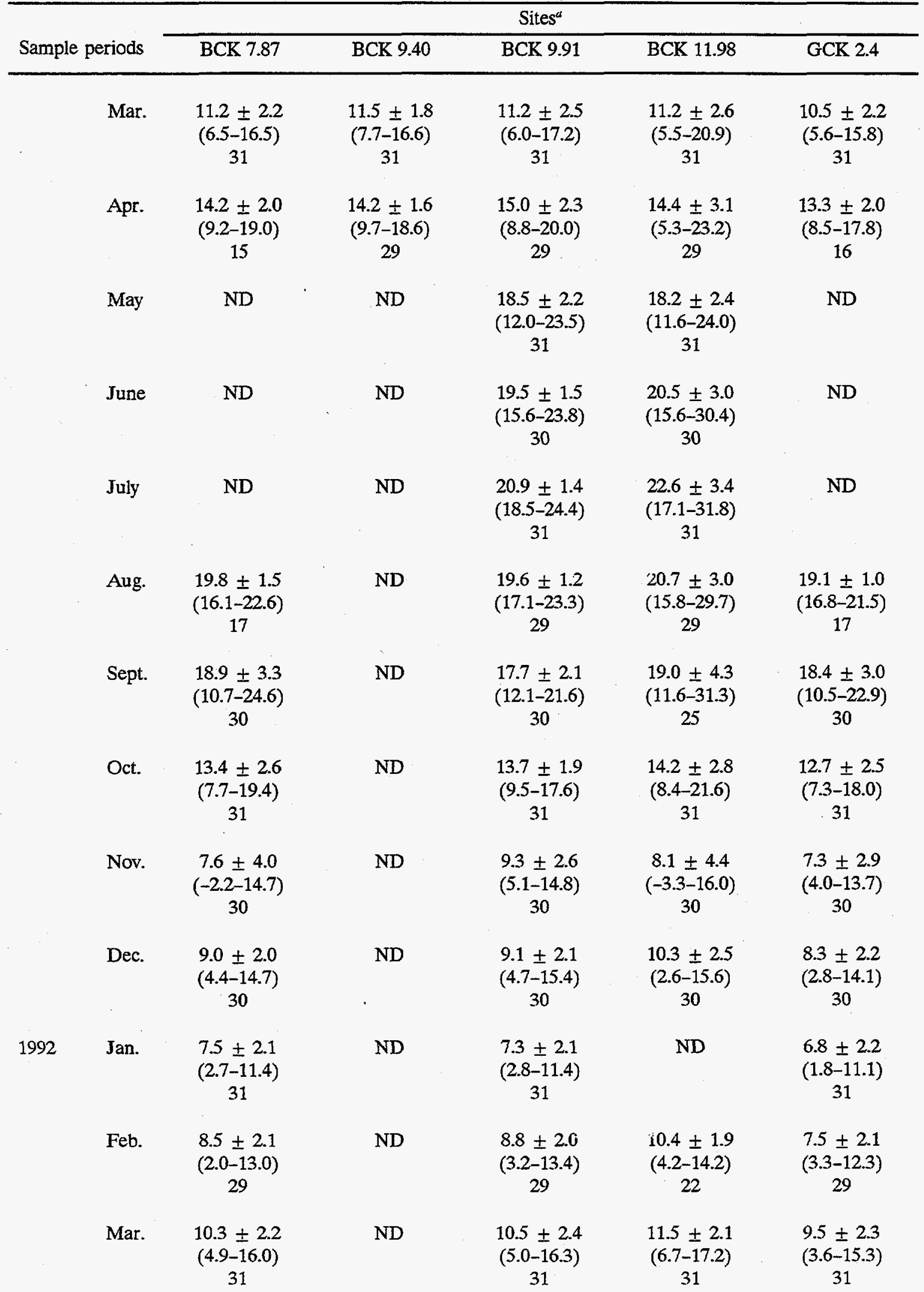


Table A.6 (continued)

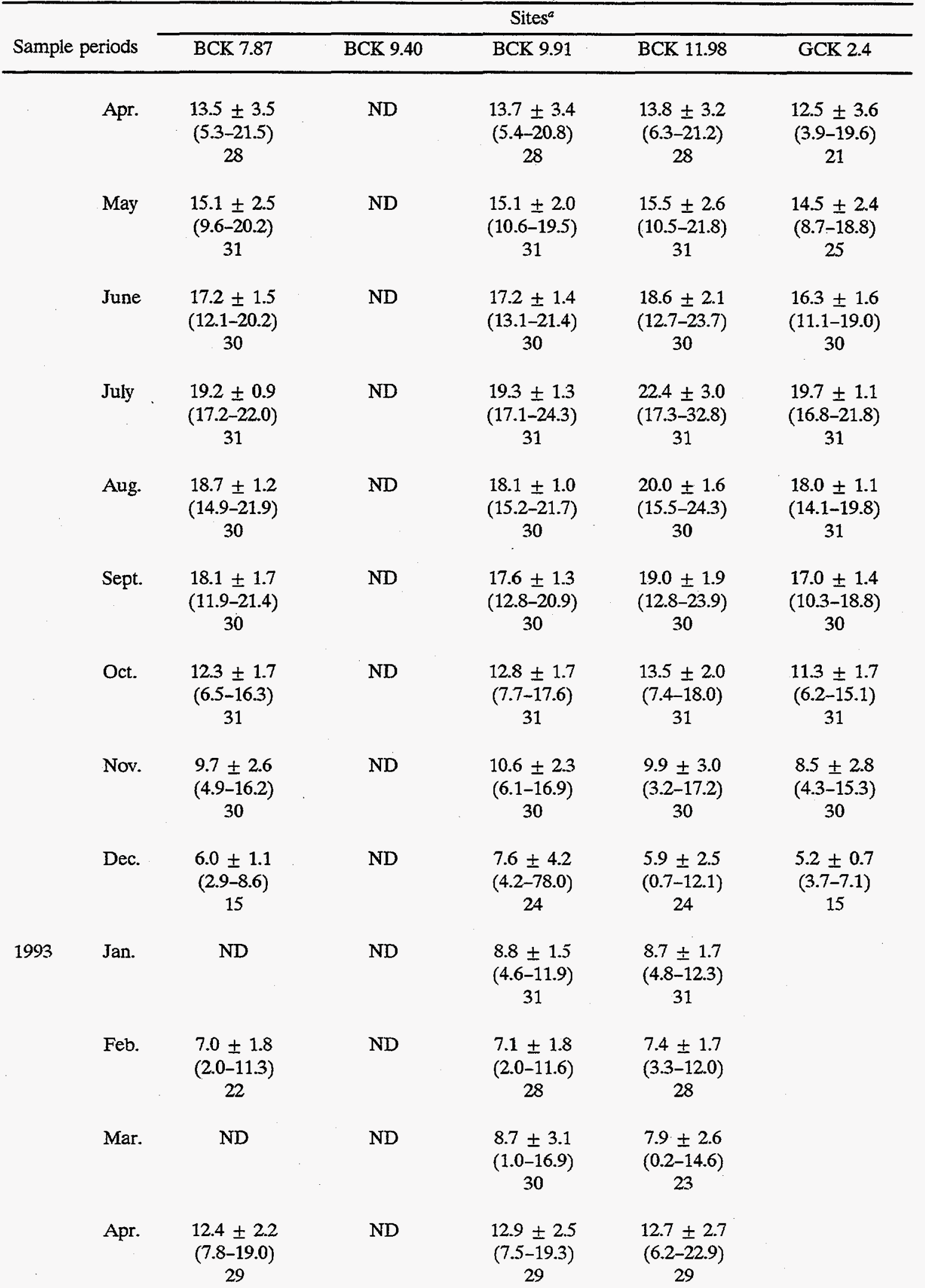


Table A6 (continued)

\begin{tabular}{|c|c|c|c|c|c|}
\hline \multirow[b]{2}{*}{ Sample periods } & \multicolumn{5}{|c|}{ Sites $^{a}$} \\
\hline & BCK 7.87 & BCK 9.40 & BCK 9.91 & BCK 11.98 & GCK 2.4 \\
\hline May & $\begin{array}{c}15.4 \pm 1.8 \\
(10.7-19.1)\end{array}$ & ND & $\begin{array}{l}16.0 \pm 1.7 \\
(11.8-20.8)\end{array}$ & $\begin{array}{l}16.5 \pm 2.1 \\
(11.3-23.4)\end{array}$ & \\
\hline & 31 & & 31 & 31 & \\
\hline June & $\begin{array}{l}18.4 \pm 1.7 \\
(12.7-21.5)\end{array}$ & ND & $\begin{array}{l}17.8 \pm 1.1 \\
(14.2-21.2)\end{array}$ & $\begin{array}{r}18.8 \pm 2.1 \\
(14.0-24.0)\end{array}$ & \\
\hline & 30 & & 30 & 30 & \\
\hline July & $\begin{array}{l}21.6 \pm 1.3 \\
(17.5-25.0)\end{array}$ & ND & $\begin{array}{l}20.2 \pm 1.2 \\
(17.1-26.0)\end{array}$ & $\begin{array}{l}20.9 \pm 2.9 \\
(16.2-27.9)\end{array}$ & \\
\hline & 29 & & 29 & 29 & GHK 2.9 \\
\hline Aug. & $\begin{array}{l}20.9 \pm 1.6 \\
(16.8-25.0)\end{array}$ & ND & $\begin{array}{l}19.6 \pm 1.1 \\
(16.4-22.4)\end{array}$ & $\begin{array}{l}20.8 \pm 2.4 \\
(15.6-27.4)\end{array}$ & $\begin{array}{l}19.1 \pm 0.8 \\
(17.2-20.9)\end{array}$ \\
\hline & 31 & & 31 & 31 & 11 \\
\hline Sept. & $\begin{array}{c}18.1 \pm 2.7 \\
(10.1-24.6)\end{array}$ & ND & $\begin{array}{l}17.6 \pm 2.1 \\
(11.6-22.6)\end{array}$ & $\begin{array}{l}18.9 \pm 2.7 \\
(11.4-27.0)\end{array}$ & $\begin{array}{c}16.8 \pm 2.0 \\
(10.2-20.6)\end{array}$ \\
\hline & 30 & & 30 & 30 & 30 \\
\hline Oct. & $\begin{array}{l}12.6 \pm 2.5 \\
(6.6-19.1)\end{array}$ & ND & $\begin{array}{l}12.9 \pm 1.7 \\
(8.7-16.6)\end{array}$ & $\begin{array}{l}13.8 \pm 2.7 \\
(7.2-20.6)\end{array}$ & $\begin{array}{c}12.7 \pm 1.9 \\
(8.0-16.2)\end{array}$ \\
\hline & 30 & & 30 & 30 & 31 \\
\hline Nov. & $\begin{array}{l}8.8 \pm 2.7 \\
(4.1-15.3)\end{array}$ & ND & $\begin{array}{c}10.0 \pm 1.9 \\
(6.4-15.6)\end{array}$ & $\begin{array}{l}9.4 \pm 2.8 \\
(4.2-16.8)\end{array}$ & $\begin{array}{l}9.3 \pm 2.0 \\
(5.6-14.4)\end{array}$ \\
\hline & 30 & & 30 & 30 & 30 \\
\hline Dec. & $\begin{array}{l}7.2 \pm 2.1 \\
(2.0-11.0)\end{array}$ & ND & $\begin{array}{c}7.6 \pm 2.1 \\
(2.8-11.5)\end{array}$ & $\begin{array}{l}7.1 \pm 2.2 \\
(1.6-11.3)\end{array}$ & $\begin{array}{l}7.1 \pm 2.3 \\
(0.4-11.1)\end{array}$ \\
\hline & 31 & & 31 & 31 & 31 \\
\hline
\end{tabular}

${ }^{\circ} \mathrm{BCK}=$ Bear Creek kilometer; $\mathrm{GCK}=$ Grassy Creek kilometer; $\mathrm{GHK}=$ Gum Hollow kilometer.

${ }^{b} \mathrm{ND}=$ no data. 
Table A7. Concentrations of polychlorinated biphenyls (PCBs) and mercury in fish from Bear Creek, 1987-93

\begin{tabular}{|c|c|c|c|c|c|c|c|c|c|c|}
\hline Site & Date & Spp & Sex & Tag & $\begin{array}{l}W t \\
(g)\end{array}$ & $\begin{array}{l}\text { Lgth } \\
(\mathrm{cm})\end{array}$ & $\underset{(\mu \mathrm{g} / \mathrm{g})}{\mathrm{Hg}}$ & $\begin{array}{c}\Sigma \mathrm{PCB}^{a} \\
(\mu \mathrm{g} / \mathrm{g})\end{array}$ & $\begin{array}{c}\mathrm{PCB}^{b} \\
1254 \\
(\mu \mathrm{g} / \mathrm{g})\end{array}$ & $\begin{array}{c}\mathrm{PCB}^{c} \\
1260 \\
(\mu \mathrm{g} / \mathrm{g})\end{array}$ \\
\hline BCK 0.6 & $12 / 22 / 87$ & REDBRE & $\mathbf{M}$ & 7128 & 89.0 & 18.3 & 0.19 & 2.6 & 1.5 & 1.1 \\
\hline BCK 0.6 & $12 / 22 / 87$ & REDBRE & $F$ & 7129 & 59.2 & 16.0 & 0.24 & 0.08 & 0.05 & 0.03 \\
\hline BCK 0.6 & $12 / 22 / 87$ & REDBRE & $F$ & 7130 & 48.3 & 14.2 & 0.42 & 0.35 & 0.18 & 0.17 \\
\hline BCK 0.6 & $12 / 22 / 87$ & REDBRE & $\mathbf{M}$ & 7131 & 30.8 & 12.5 & 0.09 & 0.23 & 0.16 & 0.07 \\
\hline BCK 0.6 & $12 / 22 / 87$ & ROCKBA & $\mathrm{F}$ & 7120 & 74.7 & 16.7 & 0.23 & 0.37 & 0.22 & 0.15 \\
\hline BCK 0.6 & $12 / 22 / 87$ & ROCKBA & $\mathbf{M}$ & 7121 & 116.7 & 19.1 & 0.24 & 0.28 & 0.17 & 0.11 \\
\hline BCK 0.6 & $12 / 22 / 87$ & ROCKBA & F & 7122 & 87.5 & 17.3 & 0.57 & 0.28 & 0.13 & 0.15 \\
\hline BCK 0.6 & $12 / 22 / 87$ & ROCKBA & F & 7123 & 73.8 & 16.4 & 0.13 & 0.42 & 0.22 & 0.20 \\
\hline BCK 0.6 & $12 / 22 / 87$ & ROCKBA & F & 7124 & 113.4 & 19.5 & 0.71 & 0.09 & 0.05 & 0.04 \\
\hline BCK 0.6 & $12 / 22 / 87$ & ROCKBA & $\mathrm{F}$ & 7125 & 89.9 & 17. & 0.26 & 0.27 & 0.11 & 0.16 \\
\hline BCK 0.6 & $12 / 22 / 87$ & ROCKBA & M & 7126 & 98.0 & 18. & 0.14 & 0.13 & 0.06 & 0.07 \\
\hline BCK 0.6 & $12 / 22 / 87$ & ROCKBA & $\mathbf{M}$ & 7127 & 118.6 & 19.8 & 0.26 & 0.40 & 0.25 & 0.15 \\
\hline BCK 0.6 & $11 / 2$ & REDBRE & $\mathrm{M}$ & 7598 & 72.4 & 16 & 0.38 & 0.13 & 0.10 & 0.03 \\
\hline BCK 0.6 & $11 / 22 / 88$ & REDBRE & M & 7589 & 36.1 & 13.7 & 0.21 & 0.03 & 0.03 & $<0.01$ \\
\hline BCK 0.6 & $11 / 22 / 88$ & REDBRE & $\mathbf{M}$ & 7599 & 39.2 & 13.4 & 0.19 & 0.12 & 0.08 & 0.04 \\
\hline BCK 0.6 & $11 / 22 / 88$ & REDBRE & M & 7829 & 27.9 & 12.6 & 0.26 & 0.08 & 0.07 & 0.01 \\
\hline BCK 0.6 & $11 / 22 / 88$ & REDBRE & $\mathrm{M}$ & 7828 & 29.6 & 12.5 & 0.34 & 0.10 & 0.08 & 0.02 \\
\hline BCK 0.6 & $11 / 22$ & ROCKBA & $F$ & 7820 & 77.0 & 16 & 0.34 & 0.17 & 0.09 & 0.08 \\
\hline BCK 0.6 & $11 / 22 / 88$ & ROCKBA & $\mathrm{M}$ & 7821 & 80.9 & 17.2 & 0.28 & 0.12 & 0.11 & 0.01 \\
\hline BCK 0.6 & $11 / 22 / 88$ & ROCKBA & $\mathrm{M}$ & 7822 & 78.8 & 16.6 & 0.23 & 0.20 & 0.12 & 0.08 \\
\hline BCK 0.6 & $11 / 22 / 88$ & ROCKBA & $\mathrm{F}$ & 7823 & 59.4 & 16.0 & 0.41 & 0.18 & 0.10 & 0.08 \\
\hline BCK 0.6 & $11 / 22 / 88$ & ROCKBA & $\mathbf{M}$ & 7824 & 83.3 & 17.4 & 0.51 & 0.10 & 0.06 & 0.04 \\
\hline BCK 0.6 & $11 / 22 / 88$ & RDCKBA & $\mathbf{M}$ & 7825 & 53.4 & 15.1 & 0.36 & 0.12 & 0.09 & 0.03 \\
\hline BCK 0.6 & $11 / 22 / 88$ & ROCKBA & F & 7826 & 63.1 & 15.9 & 0.38 & 0.51 & 0.22 & 0.29 \\
\hline BCK 0.6 & $11 / 22 / 88$ & ROCKBA & F & 7827 & 192.6 & 22.5 & 0.78 & 0.08 & 0.05 & 0.03 \\
\hline BCK 0.6 & $05 / 22 / 89$ & ROCKBA & $\mathrm{M}$ & 7490 & 135.9 & 19 & 0.29 & 0.07 & 0.04 & 0.03 \\
\hline BCK 0.6 & $05 / 22 / 89$ & ROCKBA & $\mathbf{M}$ & 7491 & 122.5 & 18.2 & 0.36 & 0.09 & 0.05 & 0.04 \\
\hline BCK 0.6 & $05 / 22 / 89$ & ROCKBA & $F$ & 7492 & 86.2 & 17.2 & 0.42 & 0.17 & 0.08 & 0.09 \\
\hline BCK 0.6 & $05 / 22 / 89$ & ROCKBA & $\mathbf{M}$ & 7493 & 111.2 & 17.4 & 0.21 & 0.20 & 0.09 & 0.11 \\
\hline BCK 0.6 & $05 / 22 / 89$ & ROCKBA & $\mathbf{M}$ & 7494 & 101.5 & 18.2 & 0.33 & 0.19 & 0.10 & 0.09 \\
\hline BCK 0.6 & $05 / 22 / 89$ & ROCKBA & $\mathbf{M}$ & 7495 & 163.2 & 20.5 & 0.34 & 0.15 & 0.06 & 0.09 \\
\hline BCK 0.6 & $05 / 22 / 89$ & ROCKBA & $\mathbf{M}$ & 7496 & 270.2 & 25.0 & 0.50 & 0.09 & 0.04 & 0.05 \\
\hline BCK 0.6 & $05 / 22 / 89$ & ROCKBA & $\mathbf{M}$ & 7497 & 107.3 & 18.0 & 0.23 & 0.14 & 0.07 & 0.07 \\
\hline BCK 0.6 & $11 / 20$ & $\mathrm{BA}$ & $\mathrm{F}$ & 5090 & 113.2 & 19.2 & 0.59 & 16 & 0.08 & 0.08 \\
\hline BCK 0.6 & $11 / 20 / 89$ & ROCKBA & $\mathrm{F}$ & 5091 & 206.2 & 23.0 & 0.67 & 0.13 & 0.07 & 0.06 \\
\hline BCK 0.6 & $11 / 20 / 89$ & ROCKBA & $\mathrm{F}$ & 5092 & 100.4 & 18.0 & 0.56 & 0.31 & 0.14 & 0.17 \\
\hline BCK 0.6 & $11 / 20 / 89$ & ROCKBA & $\mathbf{M}$ & 5093 & 106.6 & 18.3 & 0.30 & 0.88 & 0.41 & 0.37 \\
\hline BCK 0.6 & $11 / 20 / 89$ & ROCKBA & $\mathbf{M}$ & 5094 & 81.8 & 17.6 & 0.59 & 0.44 & 0.24 & 0.20 \\
\hline BCK 0.6 & $11 / 20 / 89$ & ROCKBA & M & 5095 & 156.9 & 21.0 & 0.56 & 0.38 & 0.18 & 0.20 \\
\hline BCK 0.6 & $11 / 20 / 89$ & ROCKBA & $M$ & 5096 & 165.9 & 20.5 & 0.51 & 1.67 & 0.65 & 1.02 \\
\hline BCK 0.6 & $11 / 20 / 89$ & ROCKBA & $\mathrm{M}$ & 5097 & 66.2 & 16.2 & 0.39 & 0.18 & 0.09 & 0.09 \\
\hline
\end{tabular}


Table A.7 (continued)

\begin{tabular}{|c|c|c|c|c|c|c|c|c|c|c|}
\hline Site & Date & $s_{p} p$ & Sex & Tag & $\begin{array}{l}\text { Wt } \\
(\mathrm{g})\end{array}$ & $\begin{array}{l}\text { Lgth } \\
(\mathrm{cm})\end{array}$ & $\begin{array}{c}\mathrm{Hg} \\
(\mu \mathrm{g} / \mathrm{g})\end{array}$ & $\begin{array}{c}\Sigma \mathrm{PCB}^{a} \\
(\mu \mathrm{g} / \mathrm{g})\end{array}$ & $\begin{array}{c}\mathrm{PCB}^{b} \\
1254 \\
(\mu \mathrm{g} / \mathrm{g})\end{array}$ & $\begin{array}{c}\mathrm{PCB}^{c} \\
1260 \\
(\mu \mathrm{g} / \mathrm{g})\end{array}$ \\
\hline BCK 4.5 & $05 / 25 / 90$ & REDBRE & $\mathrm{M}$ & 5414 & 160.6 & 19.7 & 0.24 & 1.21 & 0.51 & 0.70 \\
\hline BCK 4.5 & $05 / 25 / 90$ & REDBRE & $\mathbf{M}$ & 5415 & 123.5 & 18.5 & 0.41 & 0.38 & 0.21 & 0.17 \\
\hline BCK 4.5 & $05 / 25 / 90$ & REDBRE & $\mathrm{F}$ & 5416 & 63.3 & 14.7 & 0.23 & 0.30 & 0.16 & 0.14 \\
\hline BCK 4.5 & $05 / 25 / 90$ & REDBRE & $\mathrm{F}$ & 5417 & 70.5 & 15.7 & 0.27 & 0.60 & 0.36 & 0.24 \\
\hline BCK 4.5 & $05 / 25 / 90$ & REDBRE & $F$ & 5410 & 80.3 & 15.1 & 0.21 & 1.41 & 0.79 & 0.62 \\
\hline BCK 4.5 & $05 / 25 / 90$ & REDBRE & $F$ & 5411 & 64.0 & 15.4 & 0.29 & 1.61 & 0.92 & 0.69 \\
\hline BCK 4.5 & $05 / 25 / 90$ & REDBRE & $\mathrm{M}$ & 5412 & 167.1 & 20.2 & 0.32 & 1.91 & 0.61 & 1.30 \\
\hline BCK 4.5 & $05 / 25 / 90$ & REDBRE & $\mathrm{M}$ & 5413 & 140.1 & 19.9 & 0.17 & 0.32 & 0.19 & 0.13 \\
\hline BCK 0.6 & $05 / 23 / 90$ & ROCKBA & $\mathrm{F}$ & 5891 & 73.3 & 16.4 & 0.40 & 0.64 & 0.13 & 0.51 \\
\hline BCK 0.6 & $05 / 23 / 90$ & ROCKBA & $\mathrm{M}$ & 5892 & 155.3 & 20.0 & 0.34 & 0.18 & 0.07 & 0.11 \\
\hline BCK 0.6 & $05 / 23 / 90$ & ROCKBA & $\mathrm{M}$ & 5893 & 149.7 & 19.9 & 0.27 & 0.44 & 0.20 & 0.24 \\
\hline BCK 0.6 & $05 / 23 / 90$ & ROCKBA & $\mathrm{F}$ & 5894 & 185.5 & 20.5 & 0.60 & 0.08 & 0.04 & 0.04 \\
\hline BCK 0.6 & $05 / 23 / 90$ & ROCKBA & $\mathrm{M}$ & 5895 & 94.9 & 18.4 & 0.30 & 0.26 & 0.11 & 0.15 \\
\hline BCK 0.6 & $05 / 23 / 90$ & ROCKBA & $F$ & 5896 & 130.8 & 19.8 & 0.43 & 0.11 & 0.06 & 0.05 \\
\hline BCK 0.6 & $05 / 23 / 90$ & ROCKBA & $\mathrm{M}$ & 5897 & 193.5 & 22.1 & 0.40 & 0.22 & 0.12 & 0.10 \\
\hline BCK 0.6 & $05 / 23 / 90$ & ROCKBA & $\mathbf{M}$ & 5898 & 97.0 & 17.0 & 0.41 & 0.13 & 0.06 & 0.07 \\
\hline BCK 4.5 & $11 / 15 / 90$ & ROCKBA & $\mathbf{M}$ & 5300 & 261.4 & 23 & 0.58 & 0.70 & 0.41 & 0.29 \\
\hline BCK 4.5 & $11 / 15 / 90$ & RUCKBA & M & 5301 & 90.9 & 17.7 & 0.30 & 2.91 & 1.50 & 1.41 \\
\hline BCK 4.5 & $11 / 15 / 90$ & ROCKBA & $\mathrm{F}$ & 5302 & 107.7 & 18.0 & 0.68 & 1.13 & 0.61 & 0.52 \\
\hline BCK 4.5 & $11 / 15 / 90$ & ROCKBA & $\mathbf{M}$ & 5303 & 131.0 & 19.2 & 0.50 & 1.77 & 0.94 & 0.83 \\
\hline BCK 0.6 & $11 / 15$ & ROCKBA & $\mathrm{F}$ & & 113.4 & & & & 0.04 & 0.03 \\
\hline BCK 0.6 & $11 / 15 / 90$ & ROCKBA & $\mathrm{M}$ & 5783 & 83.9 & 17. & 0.3 & 0.38 & 0.23 & 0.15 \\
\hline BCK 0.6 & $11 / 15 / 90$ & ROCKBA & M & 5784 & 158.2 & 20.5 & 0. & 0.38 & 0.23 & 0.15 \\
\hline BCK 0.6 & $11 / 15 / 90$ & ROCKBA & $\mathrm{F}$ & 5785 & 100.7 & 17 & 0 . & 0 & 0.07 & 0.09 \\
\hline BCK 0.6 & $11 / 15 / 90$ & ROCKBA & $\mathrm{F}$ & 5786 & 66.4 & 15 & 0. & 6 & 0.39 & 0.47 \\
\hline BCK 0.6 & $11 / 15 / 90$ & ROCKBA & $\mathrm{F}$ & 5787 & 72.8 & 16 & 0. & & 0.03 & 0.08 \\
\hline BCK 0.6 & $11 / 15 / 90$ & ROCKBA & $F$ & 5788 & 113.8 & 18 & 0. & & 0.39 & 0.49 \\
\hline BCK 0.6 & $11 / 15 / 90$ & ROCKBA & $\mathrm{F}$ & 5789 & 144.9 & 20.6 & 0.63 & 0.14 & 0.04 & 0.10 \\
\hline BCK 4.5 & 91 & REDBRE & $\mathbf{M}$ & & 48 & & & & 0.06 & 0.05 \\
\hline BCK 4.5 & $05 / 30 / 91$ & REDBRE & $\mathrm{F}$ & 3499 & 31 & 13 & 0. & 0. & 0.08 & 0.21 \\
\hline BCK 4.5 & $05 / 30 / 91$ & REDBRE & $\mathrm{F}$ & 3084 & 34.3 & 12.2 & 0. & 0.84 & 0.36 & 0.48 \\
\hline BCK 4.5 & $05 / 30 / 91$ & REDBRE & $\mathbf{M}$ & 3047 & 88.4 & 16.5 & 0.24 & 0.79 & 0.47 & 0.32 \\
\hline BCK 0.6 & & ROCKBA & IVI & & & & & & 0.02 & $<0.01$ \\
\hline BCK 0.6 & $05 / 30 / 91$ & ROCKBA & $\mathrm{F}$ & 8429 & 153.3 & 20.0 & 0.79 & 0.04 & 0.02 & 0.02 \\
\hline BCK 0.6 & $05 / 30 / 91$ & ROCKBA & $\mathbf{M}$ & 9601 & 62.2 & 18.2 & 0.29 & $<0.01$ & $<0.01$ & $<0.01$ \\
\hline BCK 0.6 & $05 / 30 / 91$ & ROCKBA & $\mathrm{F}$ & 5809 & 76.8 & 16.0 & 0.46 & 0.22 & 0.10 & 0.12 \\
\hline 3CK 0.6 & $05 / 30 / 91$ & $\mathrm{ROCKBA}$ & $\mathrm{M}$ & 5831 & 128.8 & 19.4 & 0.40 & 0.45 & 0.20 & 0.25 \\
\hline 3CK 0.6 & $05 / 30 / 91$ & ROCKBA & $\mathbf{M}$ & 8588 & 104.3 & 17.7 & 0.38 & 0.01 & $<0.01$ & 0.01 \\
\hline BCK 0.6 & $05 / 30 / 91$ & ROCKBA & $\mathrm{M}$ & 6691 & 152.4 & 21.0 & 0.51 & 0.15 & 0.05 & 0.10 \\
\hline ВCK 0.6 & $05 / 30 / 91$ & ROCKBA & & 5837 & 146.5 & 20.3 & 0.32 & $<0.01$ & $<0.01$ & $<0.01$ \\
\hline
\end{tabular}


Table A.7 (continued)

\begin{tabular}{|c|c|c|c|c|c|c|c|c|c|c|}
\hline Site & Date & Spp & Sex & Tag & $\begin{array}{l}\text { Wt } \\
(\mathrm{g})\end{array}$ & $\begin{array}{l}\text { Lgth } \\
\text { (cm) }\end{array}$ & $\begin{array}{c}\mathrm{Hg} \\
(\mu \mathrm{g} / \mathrm{g})\end{array}$ & $\begin{array}{c}\Sigma \mathrm{PCB}^{a} \\
(\mu \mathrm{g} / \mathrm{g})\end{array}$ & $\begin{array}{c}\mathrm{PCB}^{b} \\
1254 \\
(\mu \mathrm{g} / \mathrm{g})\end{array}$ & $\begin{array}{c}\mathrm{PCB}^{c} \\
1260 \\
(\mu \mathrm{g} / \mathrm{g})\end{array}$ \\
\hline BCK 4.5 & $11 / 20 / 91$ & ROCKBA & F & 3194 & 159.2 & 20.5 & 0.80 & 0.13 & 0.06 & 0.07 \\
\hline BCK 4.5 & $11 / 20 / 91$ & ROCKBA & F & 3195 & 103.9 & 17.5 & 0.66 & 0.11 & 0.06 & 0.05 \\
\hline BCK 4.5 & $11 / 20 / 91$ & ROCKBA & M & 3196 & 91.1 & 17.2 & 0.50 & 0.09 & 0.04 & 0.05 \\
\hline BCK 4.5 & $11 / 20 / 91$ & ROCKBA & $\mathrm{F}$ & 3197 & 188.9 & 21.8 & 1.13 & 0.03 & 0.01 & 0.02 \\
\hline BCK 0.6 & $11 / 20 / 91$ & ROCKBA & M & 3180 & 150.6 & 20.8 & 0.55 & 0.08 & 0.04 & 0.04 \\
\hline BCK 0.6 & $11 / 20 / 91$ & ROCKBA & M & 3181 & 152.9 & 20.5 & 0.57 & 0.14 & 0.05 & 0.09 \\
\hline BCK 0.6 & $11 / 20 / 91$ & ROCKBA & M & 3182 & 78.5 & 16.8 & 0.46 & 0.12 & 0.07 & 0.05 \\
\hline BCK 0.6 & $11 / 20 / 91$ & ROCKBA & M & 3183 & 144.7 & 20.3 & 0.51 & 0.08 & 0.04 & 0.04 \\
\hline BCK 0.6 & $11 / 20 / 91$ & ROCKBA & F & 3184 & 193.2 & 22.5 & 0.63 & 0.03 & 0.01 & 0.02 \\
\hline BCK 0.6 & $11 / 20 / 91$ & ROCKBA & M & 3185 & 266.1 & 24.5 & 0.88 & 0.10 & 0.04 & 0.06 \\
\hline BCK 0.6 & $11 / 20 / 91$ & ROCKBA & M & 3186 & 111.6 & 18.4 & 0.39 & 0.04 & 0.02 & 0.02 \\
\hline BCK 0.6 & $11 / 20 / 91$ & ROCKBA & $\mathbf{M}$ & 3187 & 73.9 & 15.8 & 0.53 & 0.08 & 0.03 & 0.05 \\
\hline BCK 4.5 & $05 / 18$ & ROC & M & 3596 & 234.7 & 22.5 & 0.46 & 0.18 & 0.08 & 0.10 \\
\hline BCK 4.5 & $05 / 18 / 92$ & ROCKBA & M & 3597 & 71.2 & 15.7 & 0.38 & 0.11 & 0.05 & 0.06 \\
\hline BCK 4.5 & $05 / 18 / 92$ & ROCKBA & M & 3598 & 130.2 & 19.1 & 0.51 & 0.20 & 0.07 & 0.13 \\
\hline BCK 4.5 & $05 / 18 / 92$ & ROCKBA & $\mathrm{F}$ & 3599 & 385.2 & 25.0 & 0.72 & 0.15 & 0.04 & 0.11 \\
\hline BCK 0.6 & $05 / 1$ & OC & F & 3580 & 121.8 & $\mathbf{i}$ & 0.54 & 0.03 & $<0.01$ & 0.03 \\
\hline BCK 0.6 & $05 / 18 / 92$ & ROCKBA & $\mathrm{M}$ & 3581 & 155.7 & 20.4 & 0.40 & 0.12 & 0.04 & 0.08 \\
\hline BCK 0.6 & $05 / 18 / 92$ & ROCKBA & $\mathrm{F}$ & 3582 & 62.1 & 14.9 & 0.38 & 0.08 & 0.02 & 0.06 \\
\hline BCK 0.6 & $05 / 18 / 92$ & ROCKBA & M & 3583 & 90.0 & 16.9 & 0.40 & 0.07 & 0.03 & 0.04 \\
\hline BCK 0.6 & $05 / 18 / 92$ & ROCKBA & $\mathbf{M}$ & 3584 & 122.2 & 18.2 & 0.34 & 0.10 & 0.02 & 0.08 \\
\hline BCK 0.6 & $05 / 18 / 92$ & ROCKBA & F & 3585 & 111.8 & 17.9 & 0.41 & 0.02 & $<0.01$ & 0.02 \\
\hline BCK 0.6 & $05 / 18 / 92$ & ROCKBA & F & 3586 & 78.3 & 15.5 & 0.36 & 0.03 & $<0.01$ & 0.03 \\
\hline BCK 0.6 & $05 / 18 / 92$ & ROCKBA & M & 3587 & 300.6 & 25.9 & 0.75 & 0.03 & $<0.01$ & 0.03 \\
\hline $\mathrm{BCK} 4.5$ & $01 / 1$ & ROC & $\mathrm{F}$ & 4238 & 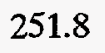 & & & & 0.03 & 0.06 \\
\hline BCK 4.5 & $01 / 13 / 93$ & ROCKBA & $\mathbf{M}$ & 4239 & 188.5 & 22.0 & 0.45 & 0.51 & 0.16 & 0.35 \\
\hline $\mathrm{BCK} 4.5$ & $01 / 13 / 93$ & ROCKBA & $\mathbf{M}$ & 4248 & 91.2 & & 0.36 & 2.45 & 0.91 & 1.54 \\
\hline BCK 4.5 & $01 / 13 / 93$ & ROCKBA & M & 4249 & 65.0 & 14.8 & 0.52 & 1.06 & 0.46 & 0.60 \\
\hline BCK 0.6 & $12 / 08 / 92$ & ROCKBA & $\mathrm{F}$ & 4220 & 65.2 & 16.0 & 0.37 & 0.08 & 0.04 & 0.04 \\
\hline BCK 0.6 & $12 / 08 / 92$ & ROCKBA & F & 4221 & 210.1 & 22.5 & 1.21 & 0.09 & 0.03 & 0.06 \\
\hline BCK 0.6 & $12 / 08 / 92$ & ROCKBA & $\mathbf{M}$ & 4222 & 95.3 & 18.0 & 0.33 & 0.23 & 0.07 & 0.16 \\
\hline BCK 0.6 & $12 / 08 / 92$ & ROCKBA & $\mathrm{F}$ & 4223 & 107.0 & 19.0 & 0.78 & 0.07 & 0.03 & 0.04 \\
\hline BCK 0.6 & $12 / 08 / 92$ & ROCKBA & M & 4224 & 129.9 & 19.6 & 0.39 & 0.08 & 0.03 & 0.05 \\
\hline BCK 0.6 & $12 / 08 / 92$ & ROCKBA & $F$ & 4225 & 198.9 & 22.7 & 0.86 & 0.07 & 0.03 & 0.04 \\
\hline BCK 0.6 & $12 / 08 / 92$ & ROCKBA & $\mathbf{M}$ & 4226 & 273.4 & 25.0 & 0.60 & 0.13 & 0.05 & 0.08 \\
\hline BCK 0.6 & $12 / 08 / 92$ & ROCKBA & M & 4227 & 87.1 & 17.7 & 0.36 & 0.36 & 0.10 & 0.26 \\
\hline BCK 4.5 & Q & ROCKBA & $\mathbf{M}$ & 4740 & 114.5 & 17.0 & 0.10 & 0.06 & $<0.01$ & 0.06 \\
\hline BCK 4.5 & $05 / 21 / 93$ & ROCKBA & $\mathbf{M}$ & 4741 & 53.3 & 13.8 & 0.16 & 0.16 & 0.04 & 0.12 \\
\hline BCK 4.5 & $05 / 21 / 93$ & ROCKBA & $\mathbf{M}$ & 4742 & 57.9 & 14.5 & 0.25 & 0.31 & 0.06 & 0.25 \\
\hline BCK 4.5 & $05 / 21 / 93$ & ROCKBA & M & 4743 & 44.2 & 13.9 & 0.12 & 0.10 & $<0.01$ & 0.10 \\
\hline
\end{tabular}


Table A.7 (continued)

\begin{tabular}{|c|c|c|c|c|c|c|c|c|c|c|}
\hline Site & Date & Spp & Sex & Tag & $\begin{array}{l}W t \\
(g)\end{array}$ & $\begin{array}{l}\text { Lgth } \\
(\mathrm{cm})\end{array}$ & $\underset{(\mu \mathrm{g} / \mathrm{g})}{\mathrm{Hg}}$ & $\begin{array}{c}\Sigma \mathrm{PCB}^{a} \\
(\mu \mathrm{g} / \mathrm{g})\end{array}$ & $\begin{array}{c}\mathrm{PCB}^{b} \\
1254 \\
(\mu \mathrm{g} / \mathrm{g})\end{array}$ & $\begin{array}{r}\mathrm{PCB}^{c} \\
1260 \\
(\mu \mathrm{g} / \mathrm{g})\end{array}$ \\
\hline BCK 0.6 & $05 / 18 / 93$ & ROCKBA & F & 4790 & 129.3 & 19.8 & 0.40 & 0.13 & 0.05 & 0.08 \\
\hline BCK 0.6 & $05 / 18 / 93$ & ROCKBA & $\mathbf{M}$ & 4791 & 198.3 & 22.8 & 0.88 & 0.08 & 0.07 & 0.01 \\
\hline BCK 0.6 & $05 / 18 / 93$ & ROCKBA & $\mathbf{M}$ & 4792 & 135.3 & 19.5 & 0.37 & 0.23 & 0.04 & 0.19 \\
\hline BCK 0.6 & $05 / 18 / 93$ & ROCKBA & $\mathbf{M}$ & 4793 & 84.5 & 16.7 & 0.36 & 0.04 & $<0.01$ & 0.04 \\
\hline BCK 0.6 & $05 / 18 / 93$ & ROCKBA & F & 4794 & 253.0 & 24.1 & 0.54 & 0.08 & $<0.01$ & 0.08 \\
\hline BCK 0.6 & $05 / 18 / 93$ & ROCKBA & $\mathrm{F}$ & 4795 & 142.2 & 19.6 & 0.78 & 0.02 & $<0.01$ & 0.02 \\
\hline BCK 0.6 & $05 / 18 / 93$ & ROCKBA & F & 4796 & 159.7 & 19.8 & 0.61 & 0.01 & $<0.01$ & 0.01 \\
\hline BCK 0.6 & $05 / 18 / 93$ & ROCKBA & $\mathrm{F}$ & 4797 & 121.0 & 18.3 & 0.63 & 0.05 & $<0.01$ & 0.05 \\
\hline BCK 4.5 & $11 / 0$ & ROC & $F$ & 4808 & 143.6 & 19 & 0.84 & 1.20 & 0.27 & 0.93 \\
\hline BCK 4.5 & $11 / 02 / 93$ & ROCKBA & F & 4809 & 149.7 & 19.5 & 0.96 & 1.75 & 0.40 & 1.35 \\
\hline BCK 4.5 & $11 / 02 / 93$ & ROCKBA & $\mathrm{F}$ & 4988 & 153.4 & 20.0 & 0.73 & 4.09 & 1.10 & 2.99 \\
\hline BCK 4.5 & $11 / 02 / 93$ & ROCKBA & $\mathrm{F}$ & 4989 & 90.8 & 16.7 & 0.61 & 0.06 & $<0.01$ & 0.06 \\
\hline BCK 0.6 & $11 / 02$ & KU & $\mathrm{F}$ & 4620 & 119.8 & 18 & 0.63 & 0.09 & $<0.01$ & 0.09 \\
\hline BCK 0.6 & $11 / 02 / 93$ & ROCKBA & $\mathbf{M}$ & 4621 & 296.1 & 24.5 & 0.89 & 0.16 & 0.02 & 0.14 \\
\hline BCK 0.6 & $11 / 02 / 93$ & ROCKBA & $\mathbf{M}$ & 4622 & 134.0 & 18.5 & 0.39 & 0.10 & 0.03 & 0.07 \\
\hline BCK 0.6 & $11 / 02 / 93$ & ROCKBA & $\mathrm{F}$ & 4623 & 61.3 & 15.5 & 0.81 & 0.15 & $<0.01$ & 0.15 \\
\hline BCK 0.6 & $11 / 02 / 93$ & ROCKBA & $\mathbf{M}$ & 4624 & 84.5 & 17.1 & 0.77 & 0.08 & $<0.01$ & 0.08 \\
\hline BCK 0.6 & $11 / 02 / 93$ & ROCKBA & $\mathbf{M}$ & 4625 & 75.6 & 16.2 & 0.45 & 0.17 & $<0.01$ & 0.17 \\
\hline BCK 0.6 & $11 / 02 / 93$ & ROCKBA & $\mathrm{F}$ & 4626 & 61.8 & 15.8 & 0.72 & 0.48 & 0.01 & 0.47 \\
\hline BCK 0.6 & $11 / 02 / 93$ & ROCKBA & $\mathrm{F}$ & 4627 & 63.5 & 16.4 & 0.54 & 0.21 & 0.12 & 0.09 \\
\hline
\end{tabular}

${ }^{\sigma}$ Total PCBs in fish axial muscle, wet weight.

${ }^{b} \mathrm{PCB}-1254$ (Arochlor 1254) in fish axial muscle, wet weight.

${ }^{C}$ PCB-1260 (Arochlor 1260) in fish axial muscle, wet weight.

Note: BCK $=$ Bear Creek kilometer; REDBRE $=$ redbreast sunfish; ROCKBA $=$ rock bass. 
Appendix B

DENSITY AND BIOMASS OF FISHES IN BEAR CREEK 

Table B.1. Fish densities (number of fish $/ \mathrm{m}^{2}$ ) in Bear Creek and in two reference streams, Grassy Creek and Mill Branch, March 1988

\begin{tabular}{|c|c|c|c|c|c|c|c|c|c|}
\hline \multirow[b]{2}{*}{ Species } & \multicolumn{9}{|c|}{ Sites $^{a}$} \\
\hline & $\begin{array}{r}\text { BCK } \\
3.25\end{array}$ & $\begin{array}{r}\text { BCK } \\
7.87\end{array}$ & $\begin{array}{r}\text { BCK } \\
9.40\end{array}$ & $\begin{array}{r}\text { BCK } \\
9.91\end{array}$ & $\begin{array}{l}\text { BCK } \\
11.09\end{array}$ & $\begin{array}{l}\text { BCK } \\
11.83\end{array}$ & $\begin{array}{l}\text { BCK } \\
12.36\end{array}$ & $\begin{array}{c}\text { GCK } \\
2.4\end{array}$ & $\begin{array}{c}\text { MBK } \\
1.6\end{array}$ \\
\hline \multicolumn{10}{|l|}{ Cyprinidae } \\
\hline Central stoneroller & 0.26 & 0.26 & 0.40 & 0.51 & 0.41 & - & - & - & 0.01 \\
\hline Striped shiner & 0.32 & 0.01 & 0.02 & 0.03 & - & - & - & - & 0.10 \\
\hline Rosefin shiner & 0.06 & - & - & - & - & - & - & - & - \\
\hline Tennessee dace & $<0.01$ & 0.97 & 0.27 & 0.32 & 0.10 & - & - & - & 0.08 \\
\hline Bluntnose minnow & $<0.01$ & - & - & - & - & - & - & - & - \\
\hline Blacknose dace & 0.64 & 1.42 & 1.24 & 0.93 & 0.72 & 0.57 & 0.01 & 0.51 & 1.52 \\
\hline Creek chub & 0.04 & 0.56 & 0.09 & 0.29 & 0.21 & 0.05 & - & 0.07 & 0.26 \\
\hline \multicolumn{10}{|l|}{ Catostomidae } \\
\hline White sucker & - & 0.01 & - & - & - & - & - & 0.04 & - \\
\hline Northern hog sucker & 0.01 & - & - & - & - & - & - & - & - \\
\hline \multicolumn{10}{|l|}{ Cottidae } \\
\hline Banded sculpin & $<0.01$ & - & 0.09 & - & - & - & - & - & - \\
\hline \multicolumn{10}{|l|}{ Centrarchidae } \\
\hline Rock bass & 0.02 & - & - & - & - & - & - & - & - \\
\hline Warmouth & - & - & - & - & - & - & - & - & 0.01 \\
\hline Bluegill & - & - & - & - & - & - & - & - & 0.01 \\
\hline \multicolumn{10}{|l|}{ Percidae } \\
\hline Stripetail darter & 0.19 & - & - & - & - & - & - & - & 0.11 \\
\hline Snubnose darter & 0.13 & - & - & - & - & - & - & - & 0.13 \\
\hline Number of species & 12 & 6 & 6 & 5 & 4 & 2 & 1 & 3 & 9 \\
\hline Total density & 1.68 & 3.23 & 2.11 & 2.08 & 1.44 & 0.62 & 0.01 & 0.62 & 2.23 \\
\hline
\end{tabular}

${ }^{a}$ BCK $=$ Bear Creek kilometer; GCK = Grassy Creek kilometer; MBK = Mill Branch kilometer. 
Table B.2. Fish densities (number of fish $/ \mathrm{m}^{2}$ ) in Bear Creek and in two reference streams, Grassy Creek and Mill Branch, October through December 1988

\begin{tabular}{|c|c|c|c|c|c|c|c|c|c|}
\hline \multirow[b]{2}{*}{ Species } & \multicolumn{9}{|c|}{ Sites $^{a}$} \\
\hline & $\begin{array}{r}\text { BCK } \\
3.25\end{array}$ & $\begin{array}{r}\text { BCK } \\
7.87\end{array}$ & $\begin{array}{r}\text { BCK } \\
9.40\end{array}$ & $\begin{array}{r}\text { BCK } \\
9.91\end{array}$ & $\begin{array}{l}\text { BCK } \\
11.09\end{array}$ & $\begin{array}{l}\text { BCK } \\
11.83\end{array}$ & $\begin{array}{l}\text { BCK } \\
12.36\end{array}$ & $\begin{array}{c}\text { GCK } \\
2.4\end{array}$ & $\begin{array}{c}\text { MBK } \\
1.6\end{array}$ \\
\hline \multicolumn{10}{|l|}{ Cyprinidae } \\
\hline Central stoneroller & 0.09 & 1.58 & 0.36 & 0.37 & 0.02 & 0.02 & - & - & - \\
\hline Striped shiner & 0.52 & 0.14 & 0.01 & - & - & - & - & - & 0.01 \\
\hline Rosefin shiner & 0.07 & - & - & - & - & - & - & - & - \\
\hline Tennessee dace & - & 0.71 & 0.23 & 0.34 & 0.01 & 0.15 & - & - & 0.04 \\
\hline Blacknose dace & 0.30 & 1.50 & 1.26 & 0.99 & 0.48 & 1.13 & 0.01 & 0.87 & 1.53 \\
\hline Creek chub & 0.04 & 0.67 & 0.13 & 0.56 & 0.10 & 0.37 & - & 0.68 & 0.27 \\
\hline \multicolumn{10}{|l|}{ Catostomidae } \\
\hline White sucker & - & 0.15 & - & 0.01 & - & - & - & - & - \\
\hline Northern hog sucker & 0.01 & - & - & - & - & - & - & - & - \\
\hline \multicolumn{10}{|l|}{ Cottidae } \\
\hline Banded sculpin & - & - & 0.04 & - & - & - & - & - & - \\
\hline \multicolumn{10}{|l|}{ Centrarchidae } \\
\hline Rock bass & 0.03 & - & - & - & - & - & - & - & - \\
\hline \multicolumn{10}{|l|}{ Percidae } \\
\hline Stripetail darter & 0.18 & - & - & - & - & - & - & - & 0.09 \\
\hline Snubnose darter & 0.22 & - & - & - & - & - & - & - & 0.14 \\
\hline Number of species & 9 & 6 & 6 & 5 & 4 & 4 & 1 & 2 & 6 \\
\hline Total density & 1.46 & 4.75 & 2.03 & 2.27 & 0.61 & 1.67 & 0.01 & 1.55 & 2.08 \\
\hline
\end{tabular}

${ }^{a} \mathrm{BCK}=$ Bear Creek kilometer; $\mathrm{GCK}=$ Grassy Creek kilometer; $\mathrm{MBK}=$ Mill Branch kilometer. 
Table B.3. Fish densities (number of fish $/ \mathrm{m}^{2}$ ) in Bear Creek and in two reference streams, Grassy Creek and Mill Branch, March through April 1989

\begin{tabular}{|c|c|c|c|c|c|c|c|c|c|}
\hline \multirow[b]{2}{*}{ Species } & \multicolumn{9}{|c|}{ Sites $^{a}$} \\
\hline & $\begin{array}{r}\text { BCK } \\
3.25\end{array}$ & $\begin{array}{r}\text { BCK } \\
7.87\end{array}$ & $\begin{array}{r}\text { BCK } \\
9.40\end{array}$ & $\begin{array}{r}\text { BCK } \\
9.91\end{array}$ & $\begin{array}{l}\text { BCK } \\
11.09\end{array}$ & $\begin{array}{c}\text { BCK } \\
11.83\end{array}$ & $\begin{array}{l}\text { BCK } \\
12.36\end{array}$ & $\begin{array}{c}\text { GCK } \\
2.4\end{array}$ & $\begin{array}{c}\mathrm{MBK} \\
1.6\end{array}$ \\
\hline \multicolumn{10}{|l|}{ Cyprinidae } \\
\hline Central stoneroller & 0.08 & 1.45 & 0.17 & 0.38 & 0.44 & 0.02 & - & - & - \\
\hline Striped shiner & 0.40 & 0.06 & 6.01 & 0.02 & - & - & - & 0.02 & - \\
\hline Rosefin shiner & 0.03 & - & - & - & - & - & - & - & - \\
\hline Tennessee dace & - & 0.70 & 0.21 & 0.16 & 0.14 & 0.04 & - & - & 0.03 \\
\hline Blacknose dace & 0.24 & 1.67 & 0.70 & 0.71 & 0.64 & 0.84 & 0.12 & 0.11 & 1.07 \\
\hline Creek chub & 0.03 & 0.87 & 0.12 & 0.33 & 0.17 & 0.43 & - & 0.11 & 0.17 \\
\hline \multicolumn{10}{|l|}{ Catostomidae } \\
\hline White sucker & - & 0.11 & - & 0.01 & - & - & - & 0.01 & - \\
\hline Northern hog sucker & 0.01 & - & - & - & - & - & - & - & - \\
\hline \multicolumn{10}{|l|}{ Cottidae } \\
\hline Banded sculpin & - & - & 0.01 & - & - & - & - & - & - \\
\hline \multicolumn{10}{|l|}{ Centrarchidae } \\
\hline Rock bass & 0.01 & - & - & - & - & - & - & - & - \\
\hline Redbreast sunfish & - & - & - & 0.01 & - & - & - & - & - \\
\hline Warmouth & - & - & - & - & - & - & - & - & 0.02 \\
\hline Bluegill & - & - & - & - & - & - & - & - & 0.02 \\
\hline \multicolumn{10}{|l|}{ Percidae } \\
\hline Stripetail darter & 0.07 & - & - & - & - & - & - & - & 0.05 \\
\hline Snubnose darter & 0.05 & - & - & - & - & - & - & - & 0.12 \\
\hline Number of species & 9 & 6 & 6 & 7 & 4 & 4 & 1 & 4 & 7 \\
\hline Total density & 0.92 & 4.86 & 1.22 & 1.62 & 1.39 & 1.33 & 0.12 & 0.25 & 1.48 \\
\hline
\end{tabular}

${ }^{a}$ BCK $=$ Bear Creek kilometer; GCK = Grassy Creek kilometer; MBK = Mill Branch kilometer. 
Table B.4. Fish densities (number of fish/ $\mathrm{m}^{2}$ ) in Bear Creek and in two reference streams, Grassy Creek and Mill Branch, October through November 1989

\begin{tabular}{|c|c|c|c|c|c|c|c|c|c|}
\hline \multirow[b]{2}{*}{ Species } & \multicolumn{9}{|c|}{ Sites $^{a}$} \\
\hline & $\begin{array}{r}\text { BCK } \\
3.25\end{array}$ & $\begin{array}{r}\text { BCK } \\
7.87\end{array}$ & $\begin{array}{r}\text { BCK } \\
9.40\end{array}$ & $\begin{array}{r}\text { BCK } \\
9.91\end{array}$ & $\begin{array}{c}\text { BCK } \\
11.09\end{array}$ & $\begin{array}{l}\text { BCK } \\
11.83\end{array}$ & $\begin{array}{l}\text { BCK } \\
12.36\end{array}$ & $\begin{array}{c}\text { GCK } \\
2.4\end{array}$ & $\begin{array}{c}\mathrm{MBK} \\
1.6\end{array}$ \\
\hline \multicolumn{10}{|l|}{ Cyprinidae } \\
\hline Central stoneroller & 0.02 & 0.21 & 1.09 & 0.59 & 0.82 & 0.06 & - & - & - \\
\hline Striped shiner & 0.11 & 0.01 & 0.01 & 0.07 & - & - & - & - & 0.01 \\
\hline Rosefin shiner & 0.03 & - & - & - & - & - & - & - & - \\
\hline Tennessee dace & - & 0.38 & 0.12 & 0.14 & 0.09 & 0.17 & 0.01 & - & 0.01 \\
\hline Blacknose dace & 0.38 & 1.22 & 1.81 & 1.45 & 2.01 & 2.96 & 1.68 & 2.12 & 0.96 \\
\hline Creek chub & 0.01 & 0.55 & 0.16 & 0.35 & 0.22 & 0.33 & 0.10 & 0.47 & 0.04 \\
\hline \multicolumn{10}{|l|}{ Catostomidae } \\
\hline White sucker & - & - & - & 0.02 & - & - & - & 0.02 & - \\
\hline \multicolumn{10}{|l|}{ Cottidae } \\
\hline Banded sculpin & - & - & 0.01 & - & - & - & - & 0.02 & - \\
\hline \multicolumn{10}{|l|}{ Centrarchidae } \\
\hline Rock bass & 0.02 & - & - & - & - & - & - & - & - \\
\hline Green sunfish & - & - & - & - & - & - & - & 0.02 & - \\
\hline Bluegill & - & - & - & - & - & - & - & - & 0.01 \\
\hline \multicolumn{10}{|l|}{ Percidae } \\
\hline Black darter & - & - & - & - & - & - & - & - & 0.06 \\
\hline Stripetail darter & 0.12 & - & - & - & - & - & - & - & 0.06 \\
\hline Snubnose darter & 0.08 & - & - & - & - & - & - & - & 0.06 \\
\hline Number of species & 8 & 5 & 6 & 6 & 4 & 4 & 3 & 5 & 8 \\
\hline Total density & 0.77 & 2.37 & 3.20 & 2.62 & 3.14 & 3.52 & 1.79 & 2.65 & 1.21 \\
\hline
\end{tabular}

${ }^{a} \mathrm{BCK}=$ Bear Creek kilometer; $\mathrm{GCK}=$ Grassy Creek kilometer; $\mathrm{MBK}=$ Mill Branch kilometer. 
Table B.5. Fish densities (number of fish/ $\mathbf{m}^{2}$ ) in Bear Creek and in two reference streams, Grassy Creek and Mill Branch, March through April 1990

\begin{tabular}{|c|c|c|c|c|c|c|c|c|c|}
\hline \multirow[b]{2}{*}{ Species } & \multicolumn{9}{|c|}{ Sites $^{a}$} \\
\hline & $\begin{array}{r}\text { BCK } \\
3.25 \\
\end{array}$ & $\begin{array}{r}\text { BCK } \\
7.87 \\
\end{array}$ & $\begin{array}{r}\text { BCK } \\
9.40 \\
\end{array}$ & $\begin{array}{r}\text { BCK } \\
9.91 \\
\end{array}$ & $\begin{array}{l}\text { BCK } \\
11.09 \\
\end{array}$ & $\begin{array}{l}\text { BCK } \\
11.83 \\
\end{array}$ & $\begin{array}{l}\text { BCK } \\
12.36 \\
\end{array}$ & $\begin{array}{c}\text { GCK } \\
2.4 \\
\end{array}$ & $\begin{array}{c}\text { MBK } \\
1.6 \\
\end{array}$ \\
\hline \multicolumn{10}{|l|}{ Cyprinidae } \\
\hline Central stoneroller & 0.09 & 0.37 & 0.34 & 0.69 & 1.41 & 0.20 & 0.03 & - & 0.01 \\
\hline Striped shiner & 0.16 & 0.02 & 0.02 & 0.14 & 0.02 & - & - & 0.04 & 0.05 \\
\hline Rosefin shiner & 0.01 & - & - & - & - & - & - & - & - \\
\hline Tennessee dace & - & 0.26 & 0.02 & 0.06 & - & 0.10 & 0.07 & - & - \\
\hline Blacknose dace & 0.27 & 1.30 & 0.66 & 1.04 & 1.47 & 2.54 & 1.31 & 0.91 & 0.63 \\
\hline Creek chub & 0.01 & 0.48 & 0.07 & 0.22 & 0.12 & 0.26 & 0.09 & 0.26 & 0.07 \\
\hline \multicolumn{10}{|l|}{ Catostomidae } \\
\hline White sucker & - & - & - & 0.05 & - & - & - & 0.01 & - \\
\hline Northern hog sucker & 0.01 & - & - & - & - & - & - & - & - \\
\hline \multicolumn{10}{|l|}{ Cottidae } \\
\hline Banded sculpin & - & - & 0.03 & - & - & - & - & 0.03 & - \\
\hline \multicolumn{10}{|l|}{ Centrarchidae } \\
\hline Rock bass & 0.01 & - & - & - & - & & & - & - \\
\hline Warmouth & - & - & - & - & - & & & - & 0.01 \\
\hline Bluegill & - & - & - & - & - & & & - & 0.05 \\
\hline \multicolumn{10}{|l|}{ Percidae } \\
\hline Black darter & - & - & - & - & - & - & - & - & 0.04 \\
\hline Stripetail darter & 0.11 & - & - & - & - & - & - & - & 0.05 \\
\hline Snubnose darter & 0.04 & - & - & - & - & - & - & - & 0.08 \\
\hline Number of species & 9 & 5 & 6 & 6 & 4 & 4 & 4 & 5 & 9 \\
\hline Total density & 0.71 & 2.43 & 1.14 & 2.20 & 3.02 & 3.10 & 1.50 & 1.25 & 0.99 \\
\hline
\end{tabular}

${ }^{a}$ BCK $=$ Bear Creek kilometer; GCK = Grassy Creek kilometer; MBK = Mill Branch kilometer. 
Table B.6. Fish densities (number of fish $/ \mathrm{m}^{2}$ ) in Bear Creek and in two reference streams, Grassy Creek and Mill Branch, October through November 1990

\begin{tabular}{|c|c|c|c|c|c|c|c|c|c|}
\hline \multirow[b]{2}{*}{ Species } & \multicolumn{9}{|c|}{ Sites $^{a}$} \\
\hline & $\begin{array}{r}\text { BCK } \\
3.25\end{array}$ & $\begin{array}{r}\text { BCK } \\
7.87\end{array}$ & $\begin{array}{r}\text { BCK } \\
9.40\end{array}$ & $\begin{array}{r}\text { BCK } \\
9.91\end{array}$ & $\begin{array}{l}\text { BCK } \\
11.09\end{array}$ & $\begin{array}{l}\text { BCK } \\
11.83\end{array}$ & $\begin{array}{l}\text { BCK } \\
12.36\end{array}$ & $\begin{array}{c}\text { GCK } \\
2.4\end{array}$ & $\begin{array}{c}\text { MBK } \\
1.6\end{array}$ \\
\hline \multicolumn{10}{|l|}{ Cyprinidae } \\
\hline Central stoneroller & 0.01 & 0.60 & 0.64 & 0.49 & 0.22 & 0.02 & 0.05 & - & 0.01 \\
\hline Striped shiner & 0.12 & - & 0.01 & 0.01 & - & - & - & - & - \\
\hline Rosefin shiner & $<0.01$ & - & - & - & - & - & - & - & - \\
\hline Tennessee dace & - & 0.09 & 0.09 & 0.04 & 0.05 & 0.06 & 0.01 & - & 0.07 \\
\hline Blacknose dace & 0.49 & 1.04 & 2.74 & 0.99 & 0.63 & 2.16 & 0.77 & 2.54 & 0.95 \\
\hline Creek chub & 0.03 & 0.34 & 0.05 & 0.48 & 0.18 & 0.18 & 0.17 & 0.83 & 0.12 \\
\hline \multicolumn{10}{|l|}{ Catostomidae } \\
\hline White sucker & - & 0.01 & - & - & - & - & - & - & - \\
\hline \multicolumn{10}{|l|}{ Cottidae } \\
\hline Banded sculpin & 0.03 & - & 0.34 & 0.01 & - & - & - & 0.04 & - \\
\hline \multicolumn{10}{|l|}{ Centrarchidae } \\
\hline Rock bass & 0.02 & - & - & - & - & - & - & - & - \\
\hline Bluegill & - & - & - & - & - & - & - & - & 0.01 \\
\hline \multicolumn{10}{|l|}{ Percidae } \\
\hline Black darter & - & - & - & - & - & - & - & - & 0.01 \\
\hline Stripetail darter & 0.10 & - & - & - & - & - & - & - & 0.12 \\
\hline Snubnose darter & 0.19 & - & - & - & - & - & - & - & 0.05 \\
\hline Number of species & 9 & 5 & 6 & 6 & 4 & 4 & 4 & 3 & 8 \\
\hline Total density & 0.99 & 2.08 & 3.87 & 2.02 & 1.08 & 2.42 & 1.00 & 3.41 & 1.34 \\
\hline
\end{tabular}

${ }^{a} \mathrm{BCK}=$ Bear Creek kilometer; GCK $=$ Grassy Creek kilometer; $\mathrm{MBK}=$ Mill Branch kilometer. 
Table B.7. Fish densities (number of fish $/ \mathrm{m}^{2}$ ) in Bear Creek and in two reference streams, Grassy Creek and Mill Branch, March through April 1991

\begin{tabular}{|c|c|c|c|c|c|c|c|c|c|}
\hline \multirow[b]{2}{*}{ Species } & \multicolumn{9}{|c|}{ Sites $^{a}$} \\
\hline & $\begin{array}{r}\text { BCK } \\
3.25\end{array}$ & $\begin{array}{r}\text { BCK } \\
7.87\end{array}$ & $\begin{array}{r}\text { BCK } \\
9.40\end{array}$ & $\begin{array}{r}\text { BCK } \\
9.91\end{array}$ & $\begin{array}{l}\text { BCK } \\
11.09\end{array}$ & $\begin{array}{l}\text { BCK } \\
11.83\end{array}$ & $\begin{array}{l}\text { BCK } \\
12.36\end{array}$ & $\begin{array}{c}\text { GCK } \\
2.4\end{array}$ & $\begin{array}{c}\text { MBK } \\
1.6\end{array}$ \\
\hline \multicolumn{10}{|l|}{ Cyprinidae } \\
\hline Central stoneroller & 0.20 & 0.42 & 0.52 & 0.64 & 1.02 & 0.08 & 0.23 & - & 0.03 \\
\hline Striped shiner & 0.11 & 0.07 & 0.07 & $<0.01$ & - & - & - & - & 0.03 \\
\hline Tennessee dace & - & 0.23 & 0.02 & 0.08 & 0.02 & - & 0.05 & - & - \\
\hline Blacknose dace & 0.35 & 0.80 & 1.27 & 0.85 & 0.83 & 1.48 & 0.88 & 0.20 & 0.60 \\
\hline Creek chub & 0.01 & 0.26 & 0.03 & 0.35 & 0.18 & 0.08 & 0.42 & 0.18 & 0.06 \\
\hline \multicolumn{10}{|l|}{ Catostomidae } \\
\hline White sucker & $<0.01$ & 0.02 & 0.01 & 0.01 & - & - & - & 0.01 & - \\
\hline \multicolumn{10}{|l|}{ Cottidae } \\
\hline Banded sculpin & 0.02 & - & 0.24 & - & - & - & - & 0.02 & - \\
\hline \multicolumn{10}{|l|}{ Centrarchidae } \\
\hline Rock bass & 0.01 & - & - & - & - & - & - & - & - \\
\hline Warmouth & - & - & - & - & - & $\because$ & - & - & 0.02 \\
\hline Bluegill & - & - & - & - & - & - & - & - & 0.03 \\
\hline \multicolumn{10}{|l|}{ Percidae } \\
\hline Black darter & - & - & - & - & - & - & - & - & 0.03 \\
\hline Stripetail darter & 0.04 & - & - & - & - & - & - & - & 0.08 \\
\hline Snubnose darter & 0.04 & - & - & - & - & - & - & - & 0.06 \\
\hline Number of species & 9 & 6 & 7 & 6 & 4 & 3 & 4 & 4 & 9 \\
\hline Total density & 0.78 & 1.80 & 2.16 & 1.93 & 2.05 & 1.64 & 1.58 & 0.41 & 0.94 \\
\hline
\end{tabular}

${ }^{a}$ BCK = Bear Creek kilometer; GCK = Grassy Creek kilometer; MBK = Mill Branch kilometer. 
Table B.8. Fish densities (number of fish/ $\mathrm{m}^{2}$ ) in Bear Creek and in two reference streams, Grassy Creek and Mill Branch, October through November 1991

\begin{tabular}{|c|c|c|c|c|c|c|c|c|c|}
\hline \multirow{2}{*}{ Species } & \multicolumn{9}{|c|}{ Sites $^{a}$} \\
\hline & $\mathrm{BCK}$ & $\mathrm{BCK}$ & $\mathrm{BCK}$ & $\mathrm{BCK}$ & BCK & BCK & $\mathrm{BCK}$ & GCK & MBK \\
\hline \multirow{2}{*}{\multicolumn{10}{|c|}{ Cyprinidae }} \\
\hline & & & & & & & & & \\
\hline Central stoneroller & 0.30 & 0.40 & 1.98 & 1.27 & Dry $^{b}$ & - & 0.66 & - & 0.02 \\
\hline Striped shiner & 0.12 & 0.92 & 0.01 & - & & - & - & - & - \\
\hline Rosefin shiner & 0.08 & - & - & - & & - & - & - & - \\
\hline Tennessee dace & 0.03 & 0.12 & 0.07 & 0.20 & & 0.21 & 0.23 & - & 0.05 \\
\hline Blacknose dace & 0.82 & 4.51 & 4.77 & 2.37 & & 2.23 & 2.32 & 3.24 & 1.15 \\
\hline Creek chub & 0.21 & 0.74 & 0.08 & 0.71 & & 0.70 & 0.69 & 0.72 & 0.33 \\
\hline \multicolumn{10}{|l|}{ Catostomidae } \\
\hline White sucker & - & 0.03 & 0.01 & - & & - & - & 0.37 & - \\
\hline Northern hog sucker & 0.02 & - & - & - & & - & - & - & - \\
\hline \multicolumn{10}{|l|}{ Cottidae } \\
\hline Banded sculpin & 0.03 & - & 0.25 & - & & - & - & - & - \\
\hline \multicolumn{10}{|l|}{ Centrarchidae } \\
\hline Rock bass & 0.10 & - & - & - & & - & - & - & - \\
\hline Green sunfish & - & - & - & - & & - & - & 0.02 & - \\
\hline \multicolumn{10}{|l|}{ Percidae } \\
\hline Stripetail darter & 0.23 & - & - & - & & - & - & - & 0.13 \\
\hline Snubnose darter & 0.32 & - & - & - & & - & - & - & 0.07 \\
\hline Number of species & 11 & 6 & 7 & 4 & & 3 & 4 & 4 & 6 \\
\hline Total density & 2.26 & 5.82 & 7.17 & 4.55 & & 3.14 & 3.90 & 4.35 & 1.75 \\
\hline
\end{tabular}

${ }^{a} \mathrm{BCK}=$ Bear Creek kilometer; GCK $=$ Grassy Creek kilometer; $\mathrm{MBK}=$ Mill Branch kilometer.

${ }^{b}$ Site not sampled during this season because the stream was dry. 
Table B.9. Fish densities (number of fish/ $\mathrm{m}^{2}$ ) in Bear Creek and in two reference streams, Grassy Creek and Mill Branch, March through April 1992

\begin{tabular}{|c|c|c|c|c|c|c|c|c|c|c|}
\hline \multirow[b]{2}{*}{ Species } & \multicolumn{10}{|c|}{ Sites $^{a}$} \\
\hline & $\begin{array}{c}\text { BCK } \\
0.7\end{array}$ & $\begin{array}{r}\text { BCK } \\
3.25\end{array}$ & $\begin{array}{r}\text { BCK } \\
7.87 \\
\end{array}$ & $\begin{array}{r}\text { BCK } \\
9.40\end{array}$ & $\begin{array}{r}\text { BCK } \\
9.91\end{array}$ & $\begin{array}{c}\text { BCK } \\
11.09\end{array}$ & $\begin{array}{c}\text { BCK } \\
11.83\end{array}$ & $\begin{array}{c}\text { BCK } \\
12.36\end{array}$ & $\begin{array}{c}\text { GCK } \\
2.4\end{array}$ & $\begin{array}{c}\text { MBK } \\
1.6\end{array}$ \\
\hline \multicolumn{11}{|l|}{ Cyprinidae } \\
\hline Central stoneroller & 0.21 & 0.86 & 0.64 & 0.70 & 1.31 & 0.19 & 0.02 & 0.85 & - & 0.01 \\
\hline Spotfin shiner & $<0.01$ & - & - & - &  & - & - & - & - & - \\
\hline Striped shiner & 0.53 & 0.21 & 0.03 & 0.01 & - & - & - & - & - & - \\
\hline Rosefin shiner & 0.11 & 0.03 & - & - & - & - & - & - & - & - \\
\hline Tennessee dace & - & 0.01 & 0.07 & 0.02 & 0.25 & 0.08 & 0.14 & 0.28 & - & 0.01 \\
\hline Bluntnose minnow & 0.02 & - & - & - & - & - & - & - & - & - \\
\hline Blacknose dace & 0.30 & 0.62 & 2.67 & 1.44 & 1.85 & 0.90 & 1.55 & 1.66 & 1.01 & 0.67 \\
\hline Creek chub & $<0.01$ & 0.07 & 0.54 & 0.10 & 0.51 & 0.12 & 0.30 & 0.84 & 0.39 & 0.23 \\
\hline \multicolumn{11}{|l|}{ Catostomidae } \\
\hline White sucker & - & - & 0.01 & - & 0.02 & - & - & - & 0.11 & - \\
\hline Northern hog sucker & - & 0.02 & - & - & - & - & - & - & - & - \\
\hline \multicolumn{11}{|l|}{ Cottidae } \\
\hline Banded sculpin & 0.08 & - & 0.01 & 0.16 & 0.01 & - & - & - & - & - \\
\hline \multicolumn{11}{|l|}{ Centrarchidae } \\
\hline Rock bass & 0.02 & 0.02 & - & - & - & - & - & - & - & - \\
\hline Warmouth & - & $\cdot$ & - & - & - & - & - & - & - & 0.01 \\
\hline Bluegill & 0.02 & - & - & - & - & - & - & - & - & 0.02 \\
\hline \multicolumn{11}{|l|}{ Percidae } \\
\hline Stripetail darter & 0.03 & 0.14 & - & - & - & - & - & - & - & 0.10 \\
\hline Snubnose darter & 0.05 & 0.14 & - & - & - & - & - & - & - & 0.06 \\
\hline Logperch & $<0.01$ & - & - & - & - & - & - & - & - & - \\
\hline Number of species & 13 & 10 & 7 & 6 & 6 & 4 & 4 & 4 & 3 & 8 \\
\hline Total density & 1.37 & 2.12 & 3.97 & 2.43 & 3.95 & 1.29 & 2.01 & 3.63 & 1.51 & 1.11 \\
\hline
\end{tabular}

${ }^{a} \mathrm{BCK}=$ Bear Creek kilometer; $\mathrm{GCK}=$ Grassy Creek kilometer; $\mathrm{MBK}=$ Mill Branch kilometer. 
Table B.10. Fish densities (number of fish $/ \mathrm{m}^{2}$ ) in Bear Creek and in two reference streams, Grassy Creek and Mill Branch, October through December 1992

\begin{tabular}{|c|c|c|c|c|c|c|c|c|c|c|}
\hline \multirow[b]{2}{*}{ Species } & \multicolumn{10}{|c|}{ Sites $^{a}$} \\
\hline & $\begin{array}{c}\text { BCK } \\
0.7 \\
\end{array}$ & $\begin{array}{r}\text { BCK } \\
3.25 \\
\end{array}$ & $\begin{array}{r}\text { BCK } \\
7.87 \\
\end{array}$ & $\begin{array}{r}\text { BCK } \\
9.40\end{array}$ & $\begin{array}{r}\text { BCK } \\
9.91\end{array}$ & $\begin{array}{l}\text { BCK } \\
11.09 \\
\end{array}$ & $\begin{array}{c}\text { BCK } \\
11.83 \\
\end{array}$ & $\begin{array}{l}\text { BCK } \\
12.36 \\
\end{array}$ & $\begin{array}{c}\text { GCK } \\
2.4 \\
\end{array}$ & $\begin{array}{c}\text { MBK } \\
1.6\end{array}$ \\
\hline \multicolumn{11}{|l|}{ Cyprinidae } \\
\hline Central stoneroller & 0.03 & 0.07 & 1.08 & 1.53 & 1.11 & 0.13 & - & 0.33 & - & 0.02 \\
\hline Spotfin shiner & 0.01 & - & - & - & - & - & - & - & - & - \\
\hline Striped shiner & 0.71 & 0.31 & 0.06 & - & - & - & - & - & 0.02 & - \\
\hline Rosefin shiner & 0.21 & 0.04 & - & - & - & - & - & - & - & - \\
\hline Tennessee dace & - & - & 0.12 & 0.20 & 0.39 & 0.08 & 0.16 & 0.16 & - & 0.07 \\
\hline Blacknose dace & 0.59 & 0.71 & 1.99 & 4.99 & 2.73 & 0.34 & 2.02 & 1.35 & 3.85 & 1.17 \\
\hline Creek chub & 0.03 & 0.17 & 0.50 & 0.51 & 1.01 & 0.30 & 1.09 & 0.54 & 0.42 & 0.69 \\
\hline \multicolumn{11}{|l|}{ Catostomidae } \\
\hline White sucker & - & - & 0.12 & - & 0.01 & - & - & - & 0.06 & - \\
\hline Northern hog sucker & 0.01 & 0.01 & - & - & - & - & - & - & - & - \\
\hline \multicolumn{11}{|l|}{ Cottidae } \\
\hline Banded sculpin & 0.34 & 0.01 & - & 0.13 & - & - & - & - & - & - \\
\hline \multicolumn{11}{|l|}{ Centrarchidae } \\
\hline Rock bass & 0.04 & 0.01 & - & - & - & - & - & - & - & - \\
\hline Redbreast sunfish & - & - & 0.01 & - & - & - & - & - & - & - \\
\hline Green sunfish & - & - & - & - & - & - & - & - & 0.02 & - \\
\hline \multicolumn{11}{|l|}{ Percidae } \\
\hline Black darter & - & - & - & - & - & - & - & - & - & 0.01 \\
\hline Stripetail darter & 0.06 & 0.11 & - & - & - & - & - & - & - & 0.16 \\
\hline Snubnose darter & 0.09 & 0.16 & - & - & - & - & - & - & - & 0.12 \\
\hline Logperch & $<0.01$ & - & - & - & - & - & - & - & - & - \\
\hline Number of species & 12 & 10 & 7 & 5 & 5 & 4 & 3 & 4 & 5 & 7 \\
\hline Total density & 2.12 & 1.60 & 3.88 & 7.36 & 5.25 & 0.85 & 3.27 & 2.38 & 4.37 & 2.24 \\
\hline
\end{tabular}

${ }^{a} \mathrm{BCK}=$ Bear Creek kilometer; GCK = Grassy Creek kilometer; $\mathrm{MBK}=$ Mill Branch kilometer. 
Table B.11. Fish densities (number of fish/ $\mathrm{m}^{2}$ ) in Bear Creck and in three reference streams; Gum Hollow Creek, Pinhook Branch, and Mill Branch; April through May 1993

\begin{tabular}{|c|c|c|c|c|c|c|c|c|c|c|c|}
\hline \multirow[b]{2}{*}{ Species } & \multicolumn{11}{|c|}{ Sites $^{a}$} \\
\hline & $\begin{array}{c}\text { BCK } \\
0.7 \\
\end{array}$ & $\begin{array}{r}\text { BCK } \\
3.25\end{array}$ & $\begin{array}{r}\text { BCK } \\
7.87\end{array}$ & $\begin{array}{r}\text { BCK } \\
9.40 \\
\end{array}$ & $\begin{array}{r}\text { BCK } \\
9.91\end{array}$ & $\begin{array}{l}\text { BCK } \\
11.09\end{array}$ & $\begin{array}{c}\text { BCK } \\
11.83\end{array}$ & $\begin{array}{c}\text { BCK } \\
12.36\end{array}$ & $\begin{array}{c}\text { GHK } \\
2.9\end{array}$ & $\begin{array}{c}\text { PHK } \\
1.6\end{array}$ & $\begin{array}{c}\text { MBK } \\
1.6\end{array}$ \\
\hline Cyprinidae & & & & & & $0.03^{b}$ & & & & & \\
\hline Central stoneroller & 0.10 & 0.19 & 1.02 & 0.58 & 0.69 & 0.61 & - & 0.46 & - & - & 0.01 \\
\hline Striped shiner & 0.61 & 0.21 & 0.02 & 0.01 & 0.01 & - & - & - & - & - & 0.01 \\
\hline Rosefin shiner & 0.18 & 0.03 & - & - & - & - & - & - & - & - & - \\
\hline Tennessee dace & - & - & 0.12 & 0.06 & 0.28 & 0.07 & 0.03 & 0.99 & 0.59 & 1.01 & 0.02 \\
\hline Bluntnose minnow & 0.01 & - & - & - & - & - & - & - & - & - & - \\
\hline Blacknose dace & 0.36 & 0.39 & 1.65 & 1.73 & 1.69 & 0.52 & 2.21 & 2.31 & 1.88 & 1.81 & 0.59 \\
\hline Creek chub & 0.02 & 0.07 & 0.43 & 0.12 & 0.58 & 0.25 & 0.90 & 1.19 & 0.87 & 0.35 & 0.22 \\
\hline \multicolumn{12}{|l|}{ Catostomidae } \\
\hline White sucker & - & 0.01 & 0.11 & - & 0.06 & - & - & - & - & - & - \\
\hline Northern hog sucker & 0.01 & 0.02 & - & - & - & - & - & - & - & - & - \\
\hline \multicolumn{12}{|l|}{ Cottidae } \\
\hline Banded sculpin & 0.10 & 0.01 & - & 0.10 & - & - & - & - & - & - & - \\
\hline \multicolumn{12}{|l|}{ Centrarchidae } \\
\hline Rock bass & 0.04 & 0.01 & - & - & - & - & - & - & - & - & . \\
\hline Redbreast sunfish & - & - & 0.01 & - & - & - & - & - & - & - & - \\
\hline Bluegill & $<0.01$ & - & - & $\cdot$ & $\cdot$ & - & - & - & - & - & 0.01 \\
\hline \multicolumn{12}{|l|}{ Percidae } \\
\hline Black darter & - & - & - & - & - & - & - & - & - & - & 0.01 \\
\hline Stripetail darter & 0.05 & 0.09 & - & - & - & - & - & - & - & - & 0.08 \\
\hline Snubnose darter & 0.07 & 0.09 & - & - & - & - & - & - & - & - & 0.02 \\
\hline Logperch & 0.01 & - & - & - & - & - & - & - & - & - & - \\
\hline Number of species & 13 & 11 & 7 & 6 & 6 & 4 & 3 & 4 & 3 & 3 & 9 \\
\hline Total density & 1.56 & 1.12 & 3.36 & 2.60 & 3.31 & 1.48 & 3.14 & 4.95 & 3.34 & 3.17 & 0.97 \\
\hline
\end{tabular}

${ }^{a}$ BCK $=$ Bear Creek kilometer; GHK = Gum Hollow Creek kilometer; PHK = Pinhook Branch kilometer; MBK = Mill Branch kilometer. ${ }^{b}$ Field identification insufficient to classify lower than family. 
Table B.12. Fish densities (number of fish $/ \mathrm{m}^{2}$ ) in Bear Creek and in three reference streams; Gum Hollow Creek, Pinhook Branch, and Mill Branch; October through December 1993

\begin{tabular}{|c|c|c|c|c|c|c|c|c|c|c|c|}
\hline \multirow[b]{2}{*}{ Species } & \multicolumn{5}{|c|}{ r } & \multicolumn{2}{|c|}{ Sites $^{a}$} & \multirow[b]{2}{*}{$\begin{array}{l}\text { BCK } \\
12.36\end{array}$} & \multirow[b]{2}{*}{$\begin{array}{c}\text { GHK } \\
2.9\end{array}$} & \multirow[b]{2}{*}{$\begin{array}{c}\text { PHK } \\
1.6\end{array}$} & \multirow[b]{2}{*}{$\begin{array}{c}\text { MBK } \\
1.6\end{array}$} \\
\hline & $\begin{array}{c}\text { BCK } \\
0.7\end{array}$ & $\begin{array}{r}\text { BCK } \\
3.25\end{array}$ & $\begin{array}{r}\text { BCK } \\
7.87\end{array}$ & $\begin{array}{r}\text { BCK } \\
9.40\end{array}$ & $\begin{array}{r}\text { BCK } \\
9.91\end{array}$ & $\begin{array}{c}\text { BCK } \\
11.09\end{array}$ & $\begin{array}{c}\text { BCK } \\
11.83\end{array}$ & & & & \\
\hline \multicolumn{12}{|l|}{ Cyprinidae } \\
\hline Central stoneroller & 0.02 & 0.06 & 1.39 & 1.78 & 0.88 & 0.84 & - & 0.30 & - & - & 0.03 \\
\hline Spotfin shiner & $<0.01$ & - & - & - & - & - & - & - & - & - & - \\
\hline Striped shiner & 0.52 & 0.51 & 0.14 & 0.02 & - & - & - & - & - & - & - \\
\hline Rosefin shiner & 0.11 & 0.03 & - & - & - & - & - & - & - & - & - \\
\hline Tennessee dace & - & - & 0.36 & 0.21 & 0.15 & 0.14 & 0.17 & 0.46 & 2.40 & 1.54 & - \\
\hline Bluntnose minnow & 0.01 & - & - & - & - & - & - & - & - & - & - \\
\hline Blacknose dace & 0.47 & 0.35 & 2.55 & 3.95 & 2.05 & 0.89 & 1.11 & 2.48 & 3.91 & 1.35 & 0.62 \\
\hline Creek chub & 0.05 & 0.11 & 0.78 & 0.15 & 0.61 & 1.07 & 0.15 & 0.66 & 1.82 & 0.51 & 0.19 \\
\hline \multicolumn{12}{|l|}{ Catostomidae } \\
\hline White sucker & - & - & 0.30 & 0.07 & 0.11 & - & - & - & - & - & - \\
\hline Northern hog sucker & $<0.01$ & $<0.01$ & - & - & - & - & - & - & - & - & - \\
\hline Black redhorse & $<0.01$ & - & - & - & - & - & - & - & - & - & - \\
\hline \multicolumn{12}{|l|}{ Cottidae } \\
\hline Banded sculpin & 0.30 & 0.02 & - & 0.11 & - & - & - & - & - & - & - \\
\hline \multicolumn{12}{|l|}{ Centrarchidae } \\
\hline Rock bass & 0.06 & 0.02 & - & - & - & - & - & - & - & - & - \\
\hline Redbreast sunfish & 0.01 & - & 0.01 & - & - & - & - & - & - & - & - \\
\hline Warmouth & $<0.01$ & - & - & - & - & - & - & - & - & - & - \\
\hline Spotted bass & - & - & - & - & - & - & - & - & - & - & 0.01 \\
\hline \multicolumn{12}{|l|}{ Percidae } \\
\hline Black darter & - & - & - & - & - & - & - & - & - & - & 0.01 \\
\hline Stripetail darter & 0.09 & 0.04 & - & - & - & - & - & - & - & - & 0.07 \\
\hline Snubnose darter & 0.11 & 0.05 & - & - & - & - & - & - & - & - & 0.07 \\
\hline Logperch & $<0.01$ & - & - & - & - & - & - & - & - & - & - \\
\hline Number of species & 16 & 10 & 7 & 7 & 5 & 4 & 3 & 4 & 3 & 3 & 7 \\
\hline Total density & 1.76 & 1.19 & 5.53 & 6.29 & 3.80 & 2.94 & 1.43 & 3.90 & 8.13 & 3.40 & 1.00 \\
\hline
\end{tabular}

${ }^{a} \mathrm{BCK}=$ Bear Creek kilometer; GHK = Gum Hollow Creek kilometer; PHK = Pinhook Branch kilometer; MBK = Mill Branch kilometer. 
Table B.13. Fish biomass ( $\mathrm{g}$ fish $/ \mathrm{m}^{2}$ ) in Bear Creek and in two reference streams, Grassy Creek and Mill Branch, March 1988

\begin{tabular}{|c|c|c|c|c|c|c|c|c|c|}
\hline \multirow[b]{2}{*}{ Species } & \multicolumn{9}{|c|}{ Sites $^{a}$} \\
\hline & $\begin{array}{r}\text { BCK } \\
3.25\end{array}$ & $\begin{array}{r}\text { BCK } \\
7.87\end{array}$ & $\begin{array}{r}\text { BCK } \\
9.40\end{array}$ & $\begin{array}{r}\text { BCK } \\
9.91\end{array}$ & $\begin{array}{l}\text { BCK } \\
11.09\end{array}$ & $\begin{array}{l}\text { BCK } \\
11.83\end{array}$ & $\begin{array}{l}\text { BCK } \\
12.36\end{array}$ & $\begin{array}{c}\text { GCK } \\
2.4\end{array}$ & $\begin{array}{c}\mathrm{MBK} \\
1.6\end{array}$ \\
\hline \multicolumn{10}{|l|}{ Cyprinidae } \\
\hline Central stoneroller & 1.98 & 0.72 & 1.53 & 1.67 & 1.45 & - & - & - & 0.01 \\
\hline Striped shiner & 0.73 & 0.01 & 0.09 & 0.15 & - & - & - & - & 0.04 \\
\hline Rosefin shiner & 0.04 & - & - & - & - & - & - & - & - \\
\hline Tennessee dace & $<0.01$ & 0.92 & 0.48 & 0.50 & 0.14 & - & - & - & 0.02 \\
\hline Bluntnose minnow & 0.01 & - & - & - & - & - & - & - & - \\
\hline Blacknose dace & 0.73 & 1.82 & 1.51 & 1.09 & 1.19 & 2.04 & 0.02 & 0.29 & 1.89 \\
\hline Creek chub & 0.09 & 2.01 & 0.46 & 3.76 & 1.39 & 0.24 & - & 0.19 & 0.56 \\
\hline \multicolumn{10}{|l|}{ Catostomidae } \\
\hline White sucker & - & 0.08 & - & - & - & - & - & 0.60 & - \\
\hline Northern hog sucker & 0.06 & - & - & - & - & - & - & - & - \\
\hline \multicolumn{10}{|l|}{ Cottidae } \\
\hline Banded sculpin & 0.01 & - & 0.12 & - & - & - & - & - & - \\
\hline \multicolumn{10}{|l|}{ Centrarchidae } \\
\hline Rock bass & 0.40 & - & - & - & - & - & - & - & - \\
\hline Warmouth & - & - & - & - & - & - & - & - & 0.40 \\
\hline Bluegill & - & - & - & - & - & - & - & - & 0.06 \\
\hline \multicolumn{10}{|l|}{ Percidae } \\
\hline Stripetail darter & 0.12 & - & - & - & - & - & - & - & 0.14 \\
\hline Snubnose darter & 0.08 & - & - & - & - & - & - & - & 0.12 \\
\hline Number of species & 12 & 6 & 6 & 5 & 4 & 2 & 1 & 3 & 9 \\
\hline Total biomass & 4.25 & 5.56 & 4.19 & 7.17 & 4.17 & 2.28 & 0.02 & 1.08 & 3.24 \\
\hline
\end{tabular}

${ }^{a} \mathrm{BCK}=$ Bear Creek kilometer; GCK $=$ Grassy Creek kilometer; $\mathrm{MBK}=$ Mill Branch kilometer. 
Table B.14. Fish biomass ( $\mathrm{g}$ fish $/ \mathrm{m}^{2}$ ) in Bear Creek and in two reference streams, Grassy Creek and Mill Branch, October through December 1988

\begin{tabular}{|c|c|c|c|c|c|c|c|c|c|}
\hline \multirow[b]{2}{*}{ Species } & \multicolumn{9}{|c|}{ Sites $^{a}$} \\
\hline & $\begin{array}{r}\text { BCK } \\
3.25\end{array}$ & $\begin{array}{r}\text { BCK } \\
7.87\end{array}$ & $\begin{array}{r}\text { BCK } \\
9.40\end{array}$ & $\begin{array}{r}\text { BCK } \\
9.91\end{array}$ & $\begin{array}{l}\text { BCK } \\
11.09\end{array}$ & $\begin{array}{l}\text { BCK } \\
11.83\end{array}$ & $\begin{array}{l}\text { BCK } \\
12.36\end{array}$ & $\begin{array}{c}\text { GCK } \\
2.4\end{array}$ & $\begin{array}{c}\text { MBK } \\
1.6\end{array}$ \\
\hline \multicolumn{10}{|l|}{ Cyprinidae } \\
\hline Central stoneroller & 0.42 & 1.16 & 0.94 & 0.87 & 0.02 & 0.03 & - & - & - \\
\hline Striped shiner & 0.65 & 0.07 & 0.64 & - & - & - & - & - & 0.01 \\
\hline Rosefin shiner & 0.06 & - & - & - & - & - & - & - & - \\
\hline Tennessee dace & - & 0.58 & 0.26 & 0.40 & $<0.01$ & 0.14 & - & - & 0.02 \\
\hline Blacknose dace & 0.39 & 1.08 & 1.42 & 1.28 & 0.42 & 1.55 & 0.01 & 0.87 & 1.18 \\
\hline Creek chub & 0.21 & 1.45 & 0.65 & 1.69 & 0.42 & 1.06 & - & 1.88 & 0.39 \\
\hline \multicolumn{10}{|l|}{ Catostomidae } \\
\hline White sucker & - & 0.23 & - & 0.18 & - & - & - & - & - \\
\hline Northern hog sucker & 0.06 & - & - & - & - & - & - & - & - \\
\hline \multicolumn{10}{|l|}{ Cottidae } \\
\hline Banded sculpin & - & - & 0.11 & - & - & - & - & - & - \\
\hline \multicolumn{10}{|l|}{ Centrarchidae } \\
\hline Rock bass & 0.51 & - & - & - & - & - & - & - & - \\
\hline \multicolumn{10}{|l|}{ Percidae } \\
\hline Stripetail darter & 0.10 & - & - & - & - & - & - & - & 0.06 \\
\hline Snubnose darter & 0.16 & - & - & - & - & - & - & - & 0.09 \\
\hline Number of species & 9 & 6 & 6 & 5 & 4 & 4 & 1 & 2 & 6 \\
\hline Total biomass & 2.56 & 4.57 & 3.42 & 4.42 & 0.86 & 2.78 & 0.01 & 2.75 & 1.75 \\
\hline
\end{tabular}

${ }^{a} \mathrm{BCK}=$ Bear Creek kilometer; $\mathrm{GCK}=$ Grassy Creek kilometer; $\mathrm{MBK}=$ Mill Branch kilometer 
Table B.15. Fish biomass ( $\mathrm{g}$ fish $/ \mathrm{m}^{2}$ ) in Bear Creek and in two reference streams, Grassy Creek and Mill Branch, March through April 1989

\begin{tabular}{|c|c|c|c|c|c|c|c|c|c|}
\hline \multirow[b]{2}{*}{ Species } & \multicolumn{9}{|c|}{ Sites $^{a}$} \\
\hline & $\begin{array}{r}\text { BCK } \\
3.25\end{array}$ & $\begin{array}{r}\text { BCK } \\
7.87\end{array}$ & $\begin{array}{r}\text { BCK } \\
9.40\end{array}$ & $\begin{array}{c}\text { BCK } \\
9.91\end{array}$ & $\begin{array}{l}\text { BCK } \\
11.09\end{array}$ & $\begin{array}{l}\text { BCK } \\
11.83\end{array}$ & $\begin{array}{l}\text { BCK } \\
12.36\end{array}$ & $\begin{array}{c}\text { GCK } \\
2.4\end{array}$ & $\begin{array}{c}\mathrm{MBK} \\
1.6\end{array}$ \\
\hline \multicolumn{10}{|l|}{ Cyprinidae } \\
\hline Central stoneroller & 0.63 & 2.28 & 0.58 & 1.24 & 1.56 & 0.06 & - & - & - \\
\hline Striped shiner & 0.54 & 0.03 & 0.07 & 0.08 & - & - & - & 0.13 & - \\
\hline Rosefin shiner & 0.02 & - & - & - & - & - & - & - & - \\
\hline Tennessee dace & - & 0.97 & 0.32 & 0.17 & 0.30 & 0.10 & - & - & 0.01 \\
\hline Blacknose dace & 0.25 & 3.17 & 1.16 & 1.58 & 1.17 & 1.20 & 0.41 & 0.15 & 1.36 \\
\hline Creek chub & 0.06 & 5.79 & 1.11 & 1.08 & 0.23 & 2.12 & - & 0.42 & 0.36 \\
\hline \multicolumn{10}{|l|}{ Catostomidae } \\
\hline White sucker & - & 0.24 & - & 0.12 & - & - & - & 0.21 & - \\
\hline Northern hog sucker & 0.25 & - & - & - & - & - & - & - & - \\
\hline \multicolumn{10}{|l|}{ Cottidae } \\
\hline Banded sculpin & - & - & 0.02 & - & - & - & - & - & - \\
\hline \multicolumn{10}{|l|}{ Centrarchidae } \\
\hline Rock bass & 0.11 & - & - & - & - & - & - & - & - \\
\hline Redbreast sunfish & - & - & - & 0.25 & - & - & - & - & - \\
\hline Warmouth & - & - & - & - & - & - & - & - & 0.11 \\
\hline Bluegill & - & - & - & - & - & - & - & - & 0.19 \\
\hline \multicolumn{10}{|l|}{ Percidae } \\
\hline Stripetail darter & 0.06 & - & - & - & - & - & - & - & 0.05 \\
\hline Snubnose darter & 0.04 & - & - & - & - & - & - & - & 0.10 \\
\hline Number of species & 9 & 6 & 6 & 7 & 4 & 4 & 1 & 4 & 7 \\
\hline Total biomass & 1.96 & 12.48 & 3.26 & 4.52 & 3.26 & 3.48 & 0.41 & 0.91 & 2.18 \\
\hline
\end{tabular}

${ }^{a} \mathrm{BCK}=$ Bear Creek kilometer; GCK = Grassy Creek kilometer; MBK = Mill Branch kilometer. 
Table B.16. Fish biomass ( $\mathrm{g}$ fish $/ \mathrm{m}^{2}$ ) in Bear Creek and in two reference streams, Grassy Creek and Mill Branch, October through November 1989

\begin{tabular}{|c|c|c|c|c|c|c|c|c|c|}
\hline \multirow[b]{2}{*}{ Species } & \multicolumn{9}{|c|}{ Sites $^{a}$} \\
\hline & $\begin{array}{r}\text { BCK } \\
3.25\end{array}$ & $\begin{array}{r}\text { BCK } \\
7.87\end{array}$ & $\begin{array}{r}\text { BCK } \\
9.40 \\
\end{array}$ & $\begin{array}{r}\text { BCK } \\
9.91 \\
\end{array}$ & $\begin{array}{l}\text { BCK } \\
11.09 \\
\end{array}$ & $\begin{array}{l}\text { BCK } \\
11.83 \\
\end{array}$ & $\begin{array}{l}\text { BCK } \\
12.36 \\
\end{array}$ & $\begin{array}{c}\text { GCK } \\
2.4 \\
\end{array}$ & $\begin{array}{c}\text { MBK } \\
1.6 \\
\end{array}$ \\
\hline \multicolumn{10}{|l|}{ Cyprinidae } \\
\hline Central stoneroller & 0.02 & 0.49 & 3.62 & 1.38 & 1.29 & 0.36 & - & - & - \\
\hline Striped shiner & 0.39 & 0.01 & 0.03 & 0.22 & - & - & - & - & $<0.01$ \\
\hline Rosefin shiner & 0.04 & - & - & - & - & - & - & - & - \\
\hline Tennessee dace & - & 0.59 & 0.19 & 0.25 & 0.12 & 0.34 & $<0.01$ & - & $<0.01$ \\
\hline Blacknose dace & 0.44 & 1.36 & 2.39 & 1.21 & 2.43 & 2.99 & 1.42 & 1.52 & 1.47 \\
\hline Creek chub & 0.01 & 1.82 & 1.04 & 2.96 & 1.41 & 1.68 & 0.31 & 2.14 & 0.30 \\
\hline \multicolumn{10}{|l|}{ Catostomidae } \\
\hline White sucker & - & - & - & 0.48 & - & - & - & 0.59 & - \\
\hline \multicolumn{10}{|l|}{ Cottidae } \\
\hline Banded sculpin & - & - & 0.01 & - & - & - & - & 0.16 & - \\
\hline \multicolumn{10}{|l|}{ Centrarchidae } \\
\hline Rock bass & 0.64 & - & - & - & - & - & - & - & - \\
\hline Green sunfish & - & - & - & - & n & - & - & 0.68 & - \\
\hline Bluegill & - & - & - & - & - & - & - & - & 0.61 \\
\hline \multicolumn{10}{|l|}{ Percidae } \\
\hline Black darter & - & - & - & - & - & - & - & - & 0.05 \\
\hline Stripetail darter & 0.09 & - & - & - & - & - & - & - & 0.05 \\
\hline Snubnose darter & 0.07 & - & - & - & - & - & - & - & 0.06 \\
\hline Number of species & 8 & 5 & 6 & 6 & 4 & 4 & 3 & 5 & 8 \\
\hline Total biomass & 1.70 & 4.27 & 7.28 & 6.50 & 5.25 & 5.37 & 1.73 & 5.09 & 2.54 \\
\hline
\end{tabular}

${ }^{a} \mathrm{BCK}=$ Bear Creek kilometer; $\mathrm{GCK}=$ Grassy Creek kilometer; $\mathrm{MBK}=$ Mill Branch kilometer. 
Table B.17. Fish biomass ( $\mathrm{g}$ fish $/ \mathrm{m}^{2}$ ) in Bear Creek and in two reference streams, Grassy Creek and Mill Branch, March through April 1990

\begin{tabular}{|c|c|c|c|c|c|c|c|c|c|}
\hline \multirow{2}{*}{ Species } & \multicolumn{9}{|c|}{ Sites $^{a}$} \\
\hline & $\begin{array}{r}\text { BCK } \\
3.25\end{array}$ & $\begin{array}{r}\text { BCK } \\
787\end{array}$ & $\begin{array}{r}\mathrm{BCK} \\
940\end{array}$ & BCK & BCK & BCK & BCK & GCK & MBK \\
\hline \multirow{2}{*}{\multicolumn{10}{|c|}{ Cyprinidae }} \\
\hline & & & & & & & & & \\
\hline Central stoneroller & 0.38 & 1.37 & 1.41 & 2.35 & 3.63 & 0.78 & 0.14 & - & 0.20 \\
\hline Striped shiner & 0.65 & 0.04 & 0.09 & 0.78 & 0.09 & - & - & 0.53 & 0.24 \\
\hline Rosefin shiner & 0.01 & - & - & - & - & - & - & - & - \\
\hline Tennessee dace & - & 0.49 & 0.04 & 0.14 & - & 0.16 & 0.14 & - & - \\
\hline Blacknose dace & 0.31 & 1.80 & 0.97 & 2.25 & 2.38 & 3.27 & 2.23 & 1.01 & 1.26 \\
\hline Creek chub & 0.12 & 1.51 & 1.01 & 3.27 & 1.39 & 1.19 & 0.70 & 1.57 & 0.25 \\
\hline \multicolumn{10}{|l|}{ Catostomidae } \\
\hline White sucker & - & $=$ & - & 1.49 & - & - & - & 0.03 & - \\
\hline Northern hog sucker & 0.41 & - & - & - & - & - & - & - & - \\
\hline \multicolumn{10}{|l|}{ Cottidae } \\
\hline Banded sculpin & - & - & 0.03 & - & - & - & - & 0.33 & - \\
\hline \multicolumn{10}{|l|}{ Centrarchidae } \\
\hline Rock bass & 0.39 & - & - & - & - & - & - & - & - \\
\hline Warmouth & - & - & - & - & - & - & - & - & 0.06 \\
\hline Bluegill & - & - & - & - & - & - & - & - & 0.63 \\
\hline \multicolumn{10}{|l|}{ Percidae } \\
\hline Black darter & - & - & - & - & - & - & - & - & 0.07 \\
\hline Stripetail darter & 0.12 & - & - & - & - & - & - & - & 0.05 \\
\hline Snubnose darter & 0.04 & - & - & - & - & - & - & - & 0.11 \\
\hline Number of species & 9 & 5 & 6 & 6 & 4 & 4 & 4 & 5 & 9 \\
\hline Total biomass & 2.43 & 5.21 & 3.55 & 10.28 & 7.49 & 5.40 & 3.21 & 3.47 & 2.87 \\
\hline
\end{tabular}

${ }^{a} \mathrm{BCK}=$ Bear Creek kilometer; GCK $=$ Grassy Creek kilometer; $\mathrm{MBK}=$ Mill Branch kilometer 
Table B.18. Fish biomass ( $\mathrm{g}$ fish/ $\mathrm{m}^{2}$ ) in Bear Creek and in two reference streams, Grassy Creek and Mill Branch, October through November 1990

\begin{tabular}{|c|c|c|c|c|c|c|c|c|c|}
\hline \multirow[b]{2}{*}{ Species } & \multicolumn{9}{|c|}{ Sites $^{a}$} \\
\hline & $\begin{array}{r}\text { BCK } \\
3.25\end{array}$ & $\begin{array}{r}\text { BCK } \\
7.87\end{array}$ & $\begin{array}{r}\text { BCK } \\
9.40\end{array}$ & $\begin{array}{r}\text { BCK } \\
9.91\end{array}$ & $\begin{array}{l}\text { BCK } \\
11.09\end{array}$ & $\begin{array}{l}\text { BCK } \\
11.83\end{array}$ & $\begin{array}{l}\text { BCK } \\
12.36 \\
\end{array}$ & $\begin{array}{c}\text { GCK } \\
2.4 \\
\end{array}$ & $\begin{array}{c}\text { MBK } \\
1.6 \\
\end{array}$ \\
\hline \multicolumn{10}{|l|}{ Cyprinidae } \\
\hline Central stoneroller & $<0.01$ & 1.85 & 1.31 & 1.27 & 0.99 & 0.11 & 0.28 & - & 0.14 \\
\hline Striped shiner & 0.36 & - & 0.02 & 0.13 & - & - & - & - & - \\
\hline Rosefin shiner & $<0.01$ & - & - & - & - & - & - & - & - \\
\hline Tennessee dace & - & 0.15 & 0.14 & 0.05 & 0.04 & 0.04 & 0.02 & - & 0.12 \\
\hline Blacknose dace & 0.61 & 1.90 & 3.77 & 1.28 & 1.10 & 2.05 & 1.01 & 2.11 & 2.33 \\
\hline Creek chub & 0.13 & 1.33 & 0.36 & 2.57 & 1.29 & 0.23 & 0.51 & 3.25 & 1.22 \\
\hline \multicolumn{10}{|l|}{ Catostomidae } \\
\hline White sucker & - & 0.04 & - & - & - & - & - & - & - \\
\hline \multicolumn{10}{|l|}{ Cottidae } \\
\hline Banded sculpin & 0.18 & - & 0.53 & 0.03 & - & - & - & 0.44 & - \\
\hline \multicolumn{10}{|l|}{ Centrarchidae } \\
\hline Rock bass & 0.45 & - & - & - & - & - & - & - & - \\
\hline Bluegill & - & - & - & - & - & - & - & - & 0.35 \\
\hline \multicolumn{10}{|l|}{ Percidae } \\
\hline Black darter & - & - & - & - & - & - & - & - & 0.01 \\
\hline Stripetail darter & 0.09 & - & - & - & - & - & - & - & 0.12 \\
\hline Snubnose darter & 0.19 & - & - & - & - & - & - & - & 0.06 \\
\hline Number of species & 9 & 5 & 6 & 6 & 4 & 4 & 4 & 3 & 8 \\
\hline Total biomass & 2.01 & 5.27 & 6.13 & 5.33 & 3.42 & 2.43 & 1.82 & 5.80 & 4.35 \\
\hline
\end{tabular}

${ }^{a} \mathrm{BCK}=$ Bear Creek kilometer; $\mathrm{GCK}=$ Grassy Creek kilometer; $\mathrm{MBK}=$ Mill Branch kilometer. 
Table B.19. Fish biomass ( $\mathrm{g} f \mathrm{sh} / \mathrm{m}^{2}$ ) in Bear Creek and in two reference streams, Grassy Creek and Mill Branch, March through April 1991

\begin{tabular}{|c|c|c|c|c|c|c|c|c|c|}
\hline \multirow[b]{2}{*}{ Species } & \multicolumn{9}{|c|}{ Sites $^{a}$} \\
\hline & $\begin{array}{r}\text { BCK } \\
3.25\end{array}$ & $\begin{array}{r}\text { BCK } \\
7.87\end{array}$ & $\begin{array}{r}\text { BCK } \\
9.40\end{array}$ & $\begin{array}{r}\text { BCK } \\
9.91\end{array}$ & $\begin{array}{l}\text { BCK } \\
11.09\end{array}$ & $\begin{array}{l}\text { BCK } \\
11.83\end{array}$ & $\begin{array}{l}\text { BCK } \\
12.36\end{array}$ & $\begin{array}{c}\text { GCK } \\
2.4\end{array}$ & $\begin{array}{c}\mathrm{MBK} \\
1.6\end{array}$ \\
\hline \multicolumn{10}{|l|}{ Cyprinidae } \\
\hline Central stoneroller & 1.19 & 1.52 & 1.62 & 2.35 & 3.02 & 0.56 & 0.60 & - & 0.54 \\
\hline Striped shiner & 0.98 & 0.62 & 0.51 & 0.05 & - & - & - & - & 0.13 \\
\hline Tennessee dace & - & 0.57 & 0.06 & 0.09 & 0.04 & - & 0.04 & - & - \\
\hline Blacknose dace & 0.50 & 1.81 & 2.05 & 1.57 & 2.05 & 2.17 & 2.10 & 0.19 & 1.23 \\
\hline Creek chub & 0.06 & 1.49 & 0.22 & 3.03 & 0.54 & 0.13 & 1.11 & 1.10 & 0.12 \\
\hline \multicolumn{10}{|l|}{ Catostomidae } \\
\hline White sucker & 0.05 & 0.17 & 0.27 & 0.40 & - & - & - & 0.36 & - \\
\hline \multicolumn{10}{|l|}{ Cottidae } \\
\hline Banded sculpin & 0.13 & - & 0.61 & - & - & - & - & 0.19 & - \\
\hline \multicolumn{10}{|l|}{ Centrarchidae } \\
\hline Rock bass & 0.38 & - & - & - & - & - & - & - & - \\
\hline Warmouth & - & - & - & - & - & - & - & - & 0.12 \\
\hline Bluegill & . & - & - & - & - & - & - & - & 0.50 \\
\hline \multicolumn{10}{|l|}{ Percidae } \\
\hline Black darter & - & - & - & - & - & - & - & - & 0.07 \\
\hline Stripetail darter & 0.06 & - & - & - & - & - & - & - & 0.10 \\
\hline Snubnose darter & 0.05 & - & - & - & - & - & - & - & 0.08 \\
\hline Number of species & 9 & 6 & 7 & 6 & 4 & 3 & 4 & 4 & 9 \\
\hline Total biomass & 3.40 & 6.18 & 5.34 & 7.49 & 5.65 & 2.86 & 3.85 & 1.84 & 2.89 \\
\hline
\end{tabular}

${ }^{a} \mathrm{BCK}=$ Bear Creek kilometer; GCK = Grassy Creek kilometer; $\mathrm{MBK}=$ Mill Branch kilometer. 
Table B.20. Fish biomass ( $\mathrm{g}$ fish/ $\mathrm{m}^{2}$ ) in Bear Creek and in two reference streams, Grassy Creek and Mill Branch, October through November 1991

\begin{tabular}{|c|c|c|c|c|c|c|c|c|c|}
\hline \multirow[b]{3}{*}{ Species } & \multicolumn{9}{|c|}{ Sites $^{a}$} \\
\hline & $\mathrm{BCK}$ & $\mathrm{BCK}$ & BCK & $\mathrm{BCK}$ & BCK & BCK & BCK & GCK & MBK \\
\hline & 3.25 & 7.87 & 9.40 & 9.91 & 11.09 & 11.83 & 12.36 & 2.4 & 1.6 \\
\hline \multicolumn{10}{|l|}{ Cyprinidae } \\
\hline Central stoneroller & 0.55 & 2.40 & 4.49 & 1.46 & $\operatorname{Dry}^{b}$ & - & 1.60 & - & 0.08 \\
\hline Striped shiner & 0.59 & 0.10 & 0.06 & - & & - & - & - & - \\
\hline Rosefin shiner & 0.02 & - & - & - & & - & - & - & - \\
\hline Tennessee dace & 0.01 & 0.18 & 0.11 & 0.18 & & 0.11 & 0.27 & - & 0.07 \\
\hline Blacknose dace & 0.90 & 3.25 & 5.99 & 2.32 & & 2.66 & 2.35 & 2.15 & 1.11 \\
\hline Creek chub & 0.92 & 3.54 & 0.36 & 2.68 & & 1.27 & 2.21 & 2.54 & 1.51 \\
\hline \multicolumn{10}{|l|}{ Catostomidae } \\
\hline White sucker & - & 0.49 & 0.01 & - & & - & - & 0.77 & - \\
\hline Northern hog sucker & 0.03 & - & - & - & & - & - & - & - \\
\hline \multicolumn{10}{|l|}{ Cottidae } \\
\hline Banded sculpin & 0.33 & - & 0.68 & - & & - & - & - & - \\
\hline \multicolumn{10}{|l|}{ Centrarchidae } \\
\hline Rock bass & 0.58 & - & - & - & & - & - & - & - \\
\hline Green sunfish & - & - & - & - & & - & - & 0.17 & - \\
\hline \multicolumn{10}{|l|}{ Percidae } \\
\hline Stripetail darter & 0.21 & - & - & - & & - & - & - & 0.11 \\
\hline Snubnose darter & 0.22 & - & - & - & & - & - & - & 0.07 \\
\hline Number of species & 11 & 6 & 7 & 4 & & 3 & 4 & 4 & 6 \\
\hline Total biomass & 4.36 & 9.96 & 11.70 & 6.64 & & 4.04 & 6.43 & 5.63 & 2.95 \\
\hline
\end{tabular}

${ }^{a} \mathrm{BCK}=$ Bear Creek kilometer; $\mathrm{GCK}=$ Grassy Creek kilometer; $\mathrm{MBK}=$ Mill Branch kilometer.

${ }^{b}$ Site not sampled during this season because the stream was dry. 
Table B.21. Fish biomass $\left(\mathrm{g}\right.$ fish $\left./ \mathrm{m}^{2}\right)$ in Bear Creek and in two reference streams, Grassy Creek and Mill Branch, March through April 1992

\begin{tabular}{|c|c|c|c|c|c|c|c|c|c|c|}
\hline \multirow[b]{2}{*}{ Species } & \multicolumn{10}{|c|}{ Sites $^{a}$} \\
\hline & $\begin{array}{c}\text { BCK } \\
0.7\end{array}$ & $\begin{array}{r}\text { BCK } \\
3.25\end{array}$ & $\begin{array}{r}\text { BCK } \\
7.87\end{array}$ & $\begin{array}{r}\text { BCK } \\
9.40\end{array}$ & $\begin{array}{r}\text { BCK } \\
9.91\end{array}$ & $\begin{array}{c}\text { BCK } \\
11.09 \\
\end{array}$ & $\begin{array}{c}\text { BCK } \\
11.83\end{array}$ & $\begin{array}{c}\text { BCK } \\
12.36\end{array}$ & $\begin{array}{c}\text { GCK } \\
2.4\end{array}$ & $\begin{array}{c}\text { MBK } \\
1.6\end{array}$ \\
\hline \multicolumn{11}{|l|}{ Cyprinidae } \\
\hline Central stoneroller & 0.82 & 3.22 & 2.39 & 1.86 & 2.19 & 0.47 & 0.08 & 1.68 & - & 0.12 \\
\hline Spotfin shiner & $<0.01$ & - & - & - & - & - & - & - & - & - \\
\hline Striped shiner & 1.87 & 1.37 & 0.25 & $<0.01$ & - & - & - & - & - & - \\
\hline Rosefin shiner & 0.09 & 0.01 & - & - & - & - & - & - & - & - \\
\hline Tennessee dace & - & $<0.01$ & 0.18 & 0.01 & 0.20 & 0.10 & 0.14 & 0.22 & - & 0.01 \\
\hline Bluntnose minnow & 0.03 & - & - & - & - & - & - & - & - & - \\
\hline Blacknose dace & 0.48 & 0.82 & 2.62 & 2.16 & 2.01 & 1.99 & 2.17 & 1.49 & 0.94 & 0.81 \\
\hline Creek chub & 0.01 & 0.26 & 1.94 & 0.42 & 2.34 & 0.45 & 0.45 & 2.40 & 1.08 & 0.85 \\
\hline \multicolumn{11}{|l|}{ Catostomidae } \\
\hline White sucker & - & - & 0.03 & - & 0.18 & - & - & - & 0.29 & - \\
\hline Northern hog sucker & - & 0.74 & - & - & - & - & - & - & - & - \\
\hline \multicolumn{11}{|l|}{ Cottidae } \\
\hline Banded sculpin & 0.71 & - & 0.07 & 0.55 & 0.03 & - & - & - & - & - \\
\hline \multicolumn{11}{|l|}{ Centrarchidae } \\
\hline Rock bass & 1.27 & 0.78 & - & - & - & - & - & - & - & - \\
\hline Warmouth & - & - & - & . & - & - & - & - & - & 0.17 \\
\hline Bluegill & 0.17 & - & - & - & - & - & - & - & - & 0.09 \\
\hline \multicolumn{11}{|l|}{ Percidae } \\
\hline Stripetail darter & 0.03 & 0.18 & - & - & - & - & - & - & - & 0.12 \\
\hline Snubnose darter & 0.06 & 0.15 & - & - & - & - & - & - & - & 0.08 \\
\hline Logperch & 0.05 & - & - & - & - & - & - & - & - & - \\
\hline Number of species & 13 & 10 & 7 & 6 & 6 & 4 & 4 & 4 & 3 & 8 \\
\hline Total biomass & 5.59 & 7.53 & 7.48 & 5.00 & 6.95 & 3.01 & 2.84 & 5.79 & 2.31 & 2.25 \\
\hline
\end{tabular}

${ }^{a} \mathrm{BCK}=$ Bear Creek kilometer; GCK = Grassy Creek kilometer; MBK = Mill Branch kilometer. 
Table B.22. Fish biomass $\left(\mathrm{g}\right.$ fish/ $\left.\mathrm{m}^{2}\right)$ in Bear Creek and in two reference streams, Grassy Creek and Mill Branch, October through December 1992

\begin{tabular}{|c|c|c|c|c|c|c|c|c|c|c|}
\hline \multirow[b]{2}{*}{ Species } & \multicolumn{10}{|c|}{ Sites $^{a}$} \\
\hline & $\begin{array}{c}\text { BCK } \\
0.7 \\
\end{array}$ & $\begin{array}{r}\text { BCK } \\
3.25 \\
\end{array}$ & $\begin{array}{r}\text { BCK } \\
7.87\end{array}$ & $\begin{array}{r}\text { BCK } \\
9.40 \\
\end{array}$ & $\begin{array}{r}\text { BCK } \\
9.91\end{array}$ & $\begin{array}{c}\text { BCK } \\
11.09\end{array}$ & $\begin{array}{c}\text { BCK } \\
11.83\end{array}$ & $\begin{array}{c}\text { BCK } \\
12.36\end{array}$ & $\begin{array}{c}\text { GCK } \\
2.4\end{array}$ & $\begin{array}{c}\text { MBK } \\
1.6\end{array}$ \\
\hline \multicolumn{11}{|l|}{ Cyprinidae } \\
\hline Central stoneroller & 0.04 & 0.10 & 1.74 & 3.90 & 1.42 & 0.17 & - & 0.69 & - & 0.06 \\
\hline Spotfin shiner & 0.02 & - & - & - & - & - & - & - & - & - \\
\hline Striped shiner & 1.17 & 1.09 & 0.08 & - & - & - & - & - & 0.25 & - \\
\hline Rosefin shiner & 0.18 & 0.03 & - & - & - & - & - & - & - & - \\
\hline Tennessee dace & - & - & 0.17 & 0.24 & 0.36 & 0.14 & 0.21 & 0.16 & - & 0.04 \\
\hline Blacknose dace & 0.58 & 0.77 & 2.40 & 5.71 & 2.30 & 0.71 & 2.74 & 0.98 & 1.87 & 1.60 \\
\hline Creek chub & 0.08 & 0.62 & 1.63 & 3.33 & 4.99 & 1.70 & 1.48 & 2.20 & 1.33 & 2.16 \\
\hline \multicolumn{11}{|l|}{ Catostomidae } \\
\hline White sucker & - & - & 0.30 & - & 0.02 & - & - & - & 0.48 & - \\
\hline Northern hog sucker & 0.76 & 0.17 & - & - & - & - & - & - & - & - \\
\hline \multicolumn{11}{|l|}{ Cottidae } \\
\hline Banded sculpin & 1.28 & 0.09 & - & 0.48 & - & - & - & - & - & - \\
\hline \multicolumn{11}{|l|}{ Centrarchidae } \\
\hline Rock bass & 0.99 & 0.01 & - & - & - & - & - & - & - & - \\
\hline Redbreast sunfish & - & - & 0.10 & - & - & - & - & - & - & - \\
\hline Green sunfish & - & - & - & - & - & - & - & - & 0.07 & - \\
\hline Warmouth & - & - & - & - & - & - & - & - & - & - \\
\hline Bluegill & - & - & - & - & - & $\cdot$ & - & - & - & - \\
\hline \multicolumn{11}{|l|}{ Percidae } \\
\hline Black darter & - & - & - & - & - & - & - & - & - & 0.01 \\
\hline Stripetail darter & 0.05 & 0.09 & - & - & - & - & - & - & - & 0.17 \\
\hline Snubnose darter & 0.09 & 0.11 & - & - & - & - & - & - & - & 0.04 \\
\hline \multirow[t]{2}{*}{ Logperch } & 0.02 & - & - & - & - & - & - & - & - & - \\
\hline & & & ' & & & & & & & \\
\hline Number of species & 12 & 10 & 7 & 5 & 5 & 4 & 3 & 4 & 5 & 7 \\
\hline Total biomass & 5.26 & 3.08 & 6.42 & 13.66 & 9.09 & 2.72 & 4.43 & 4.03 & 4.00 & 4.08 \\
\hline
\end{tabular}

${ }^{\mathrm{a}} \mathrm{BCK}=$ Bear Creek kilometer; $\mathrm{GCK}=$ Grassy Creek kilometer; $\mathrm{MBK}=$ Mill Branch kilometer. 
Table B.23. Fish biomass ( $\mathrm{g}$ fish $/ \mathrm{m}^{2}$ ) in Bear Creek and in three reference streams; Gum Hollow Creek, Pinhook Branch, and Mill Branch, April through May 1993

\begin{tabular}{|c|c|c|c|c|c|c|c|c|c|c|c|}
\hline \multirow[b]{2}{*}{ Species } & \multicolumn{11}{|c|}{ Sites $^{a}$} \\
\hline & $\begin{array}{c}\text { BCK } \\
0.7 \\
\end{array}$ & $\begin{array}{r}\text { BCK } \\
3.25 \\
\end{array}$ & $\begin{array}{r}\text { BCK } \\
7.87 \\
\end{array}$ & $\begin{array}{r}\text { BCK } \\
9.40 \\
\end{array}$ & $\begin{array}{r}\text { BCK } \\
9.91 \\
\end{array}$ & $\begin{array}{r}\text { BCK } \\
11.09 \\
\end{array}$ & $\begin{array}{c}\text { BCK } \\
11.83 \\
\end{array}$ & $\begin{array}{l}\text { BCK } \\
12.36 \\
\end{array}$ & $\begin{array}{c}\text { GHK } \\
2.9 \\
\end{array}$ & $\begin{array}{c}\text { PHK } \\
1.6 \\
\end{array}$ & $\begin{array}{c}\text { MBK } \\
1.6\end{array}$ \\
\hline Cyprinidae & & & & & & $0.48^{\mathrm{b}}$ & & & & & \\
\hline Central stoneroller & 0.43 & 0.49 & 1.95 & 1.93 & 1.73 & 3.67 & - & 2.48 & - & - & $<0.01$ \\
\hline Striped shiner & 2.02 & 0.82 & 0.04 & 0.03 & 0.02 & - & - & - & - & - & $<0.01$ \\
\hline Rosefin shiner & 0.18 & 0.03 & - & - & - & - & - & - & $\cdot$ & - & - \\
\hline Tennessec dace & - & - & 0.16 & 0.09 & 0.36 & 0.15 & 0.04 & 1.61 & 0.59 & 1.65 & 0.01 \\
\hline Bluntnose minnow & 0.02 & - & - & - & - & - & - & - & - & - & - \\
\hline Blacknose dace & 0.47 & 0.49 & 2.51 & 2.48 & 2.71 & 1.84 & 4.24 & 3.09 & 1.84 & 3.01 & 0.77 \\
\hline Creek chub & 0.07 & 0.33 & 1.33 & 0.49 & 2.76 & 2.15 & 2.27 & 7.25 & 3.46 & 2.68 & 0.89 \\
\hline \multicolumn{12}{|l|}{ Catostomidae } \\
\hline White sucker & - & 0.05 & 0.38 & - & 1.07 & - & - & - & - & - & - \\
\hline Northern hog sucker & 0.06 & 0.08 & - & $=$ & - & - & - & - & - & - & - \\
\hline \multicolumn{12}{|l|}{ Cottidae } \\
\hline Banded sculpin & 0.78 & 0.03 & - & 0.35 & - & - & - & - & - & $\because$ & - \\
\hline \multicolumn{12}{|l|}{ Centrarchidae } \\
\hline Rock bass & 1.55 & 0.03 & - & - & - & - & - & - & - & - & - \\
\hline Redbreast sunfish & - & - & 0.10 & - & - & - & - & - & - & - & - \\
\hline Bluegill & 0.05 & - & - & - & - & - & - & - & - & - & 0.03 \\
\hline \multicolumn{12}{|l|}{ Percidae } \\
\hline Black darter & - & - & - & - & - & - & - & - & - & - & $<0.01$ \\
\hline Stripetail darter & 0.04 & 0.12 & - & - & - & - & - & - & - & - & 0.08 \\
\hline Snubnose darter & 0.08 & 0.10 & - & - & - & - & - & - & - & - & 0.03 \\
\hline Logperch & 0.09 & - & - & - & - & - & - & - & - & - & - \\
\hline Number of species & 13 & 11 & 7 & 6 & 6 & 5 & 3 & 4 & 3 & 3 & 9 \\
\hline Total biomass & 5.84 & 2.57 & 6.47 & 5.37 & 8.65 & 8.29 & 6.55 & 14.43 & 5.89 & 7.34 & 1.81 \\
\hline
\end{tabular}

${ }^{a} \mathrm{BCK}=$ Bear Creek kilometer; GHK = Gum Hollow Creek kilometer; PHK = Pinhook Branch kilometer; MBK = Mill Branch kilometer.

${ }^{b}$ Field identification insufficient to classify lower than family. 
Table B.24. Fish biomass ( $\mathrm{g}$ fish/ $\mathrm{m}^{2}$ ) in Bear Creek and in three reference streams; Gum Hollow Creek, Pinhook Branch, and Mill Branch, October through November 1993

\begin{tabular}{|c|c|c|c|c|c|c|c|c|c|c|c|}
\hline \multirow[b]{2}{*}{ Species } & \multicolumn{11}{|c|}{ Sites $^{a}$} \\
\hline & $\begin{array}{c}\text { BCK } \\
0.7\end{array}$ & $\begin{array}{r}\text { BCK } \\
3.25\end{array}$ & $\begin{array}{r}\text { BCK } \\
7.87\end{array}$ & $\begin{array}{r}\text { BCK } \\
9.40\end{array}$ & $\begin{array}{r}\text { BCK } \\
9.91\end{array}$ & $\begin{array}{l}\text { BCK } \\
11.09\end{array}$ & $\begin{array}{c}\text { BCK } \\
11.83\end{array}$ & $\begin{array}{l}\text { BCK } \\
12.36\end{array}$ & $\begin{array}{c}\text { GHK } \\
2.9\end{array}$ & $\begin{array}{c}\text { PHK } \\
1.6\end{array}$ & $\begin{array}{c}\text { MBK } \\
1.6\end{array}$ \\
\hline \multicolumn{12}{|l|}{ Cyprinidae } \\
\hline Central stoneroller & 0.04 & 0.10 & 2.38 & 5.88 & 1.10 & 0.62 & - & 0.81 & - & - & 0.07 \\
\hline Spotfin shiner & $<0.01$ & .- & - & - & - & - & - & - & - & - & - \\
\hline Striped shiner & 1.24 & 1.29 & 0.32 & 0.04 & - & - & - & - & - & - & - \\
\hline Rosefin shiner & 0.12 & 0.04 & - & - & - & - & - & - & - & - & - \\
\hline Tennessee dace & - & - & 0.19 & 0.20 & 0.17 & 0.08 & 0.12 & 0.37 & 1.48 & 2.30 & - \\
\hline Bluntnose minnow & 0.01 & - & - & - & - & - & - & - & - & - & - \\
\hline Blacknose dace & 0.40 & 0.49 & 2.37 & 4.83 & 2.69 & 0.31 & 2.06 & 1.24 & 2.49 & 1.70 & 1.06 \\
\hline Creek chub & 0.11 & 0.71 & 3.99 & 1.23 & 2.11 & 1.00 & 0.40 & 2.01 & 6.61 & 2.97 & 1.74 \\
\hline \multicolumn{12}{|l|}{ Catostomidae } \\
\hline White sucker & - & - & 0.67 & 0.14 & 0.29 & - & - & - & - & - & - \\
\hline Northern hog sucker & 0.02 & 0.09 & - & - & - & - & - & - & - & - & - \\
\hline Black redhorse & 0.04 & - & - & - & - & - & - & - & - & - & - \\
\hline \multicolumn{12}{|l|}{ Cottidae } \\
\hline Banded sculpin & 1.15 & 0.13 & - & 0.27 & - & - & - & - & - & - & - \\
\hline \multicolumn{12}{|l|}{ Centrarchidae } \\
\hline Rock bass & 1.19 & 0.35 & - & - & - & - & - & - & - & - & - \\
\hline Redbreast sunfish & 0.23 & - & 0.27 & - & - & - & - & - & - & - & - \\
\hline Warmouth & $<0.01$ & - & - & - & - & - & - & - & - & - & - \\
\hline Spotted bass & - & - & - & - & - & - & - & - & - & - & 0.17 \\
\hline \multicolumn{12}{|l|}{ Percidae } \\
\hline Black darter & - & - & - & - & - & - & - & - & - & - & 0.01 \\
\hline Stripetail darter & 0.05 & 0.04 & - & - & - & - & - & - & - & - & 0.06 \\
\hline Snubnose darter & 0.09 & 0.05 & - & - & - & - & - & - & - & - & 0.07 \\
\hline Logperch & 0.04 & - & - & - & - & - & - & - & - & - & - \\
\hline Number of species & 16 & 10 & 7 & 7 & 5 & 4 & 3 & 4 & 3 & 3 & 7 \\
\hline Total biomass & 4.73 & 3.29 & 10.19 & 12.59 & 6.36 & 2.01 & 2.58 & 4.43 & 10.58 & 6.97 & 3.18 \\
\hline
\end{tabular}

${ }^{a} \mathrm{BCK}=$ Bear Creek kilometer; GHK = Gum Hollow Creek kilometer; Pinhook Branch kilometer; MBK = Mill Branch kilometer. 
Appendix C

ANALYSIS OF STATISTICAL POWER FOR DIFFERENT NUMBERS OF REPLICATES 


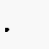




\title{
C. ABILITY TO DETECT DIFFERENCES IN BENTHIC INVERTEBRATE DATA: STATISTICAL POWER FOR DIFFERENT NUMBERS OF REPLICATES
}

\author{
(S. W. Christensen, J. J. Beauchamp, and J. G. Smith)
}

In early 1988 , it became necessary to seek the services of a new subcontractor to process benthic macroinvertebrate samples. By the time a new subcontractor had been identified and was in full operation in mid1989 , a backlog of approximately 1.5 year's worth of samples had accumulated. This backlog was exacerbated by an increased workload with which staffing could not initially keep pace. In addition to hiring more staff, a number of other measures were examined. At most monitoring sites, three replicates are generally collected on each sampling date at each site. However, during the early years of the Bear Creek monitoring project, five replicates had been collected at each site during each sampling period. One possibility in helping to reduce the backlog was to reduce the number of replicates processed from 5 to 3 for the several years that had not yet been analyzed, and to collect only three replicates per site in future sampling.

This statistical study was undertaken to explore the expected consequences of making this change on the ability to detect differences between sites using an analysis of variance (ANOVA). Five invertebrate parameters (dependent variables) were examined: density, biomass, richness of the Ephemeroptera, Plecoptera, and Trichoptera (referred to as EPT richness), total taxonomic richness, and the ratio of EPT richness to total richness. The basic questions addressed were (1) how large do site-to-site differences in the indices need to be before they can be identified as significant by an ANOVA, given either three or five replicates at the site; and
(2) can we accept the larger site-to-site differences that would be required before detection with an ANOVA using three replicates as opposed to five?

The data analyzed are based on five replicates collected during each of four sampling periods (i.e., January, April, July, and October) from October 1985 through July 1987 at each of seven sites on Bear Creek and at six reference sites. Most of these data were used, although dry conditions at one site in one year restricted the number of seasons or the number of sites that could be included. The first step involved applying Levene's test for homogeneity of variance. Where variances were clearly nonhomogeneous, transformations were applied to achieve a reasonable degree of homogeneity of variance. For indices where this was possible for one of the years but not the other, only one year was used for the analysis of that index. Based on this procedure, a log transformation was applied to density and biomass data, and a square root transformation was applied to the total species richness data. Next, a two-factor ANOVA for site and date and their interaction was performed. From this ANOVA, a pooled variance estimate and its associated number of degrees of freedom were obtained. In addition, an upper $90 \%$ confidence limit for the variance estimate was calculated, to represent pessimistic situations that would occasionally be expected to be encountered with similar data from other sites and years. Finally, these values were used to enter tables for evaluating statistical power, 
provided in Bowman and Kastenbaum (1975), to determine the needed inter-site magnitude of differences needed in the various benthic invertebrate indices before the differences would be expected to be detectable by ANOVA (i.e., result in a significant site effect). These results are presented in Tables C.1-C.5, for five or three replicates, for two levels of Type 1 error (alpha $=0.1$ and 0.05 ), and for three levels of Type 2 error (beta $=0.3,0.2$, and 0.1 ; power $=1$ minus beta). The analysis assumes that the ANOVA would be performed for data from four seasons and eleven sites.

Interpreting these tables is difficult for those who are not familiar with statistical terminology, including Type 1 and Type 2 error. The underlined values in Table C.3 are used as an interpretive example. For EPT richness, assuming a variance of 10 , we choose the conventional value of 0.05 for alpha (the Type 1 error). This implies that we are willing in each of our analyses to accept a 5\% chance of being wrong in concluding that there is a difference among sites when there is no site difference.

Next, we choose for illustration a statistical power of 0.8. This means that we accept in each analysis a $20 \%$ chance (i.e., 1 minus 0.8) of failing to detect a significant difference aruong sites when in fact there is a site effect of a size specified in the table. The value in the table is, however, also a function of the number of replicates we will use for the analysis. In this case (underlined values in Table C.3), to have the specified protection against at false differences (only a 5\% chance) with five replicates, the range, across all sites, of mean EPT species richness (averaged over the replicates collected at each site) would need to be at least as large as 4.1 (an underlined value) in order for us to have no more than a $20 \%$ chance of failing to detect the difference with ANOVA. Expressed another way, after averaging the replicates difference by ANOVA. each site, the site with the highest average number of EPT taxa would need to have at least 4.1 more taxa than the site with the minimum average number of EPT taxa. With three replicates, rather than five, the mean number of EPT taxa would need to be more different between some sites - to differ by at least 5.5 (another underlined value) - for us to have no more than a $20 \%$ chance of failing to detect the finding The interpretation is more complicated for indices requiring transformation. With a log transformation, as needed for densities (Table C.1) and biomass (Table C.2), the table entries represent multiplicative (factor) differences rather than the additive differences used in the example discussed above (EPT richness). With a square root transformation (needed for the total richness, Table C.4), the table entries represent differences in the mean square roots of the number of taxa.

Examination of these tables, in view of the objectives of the monitoring programs and the difficulty of dealing with the backlog of samples, led us to conclude that the use of three replicates rather than five would be acceptable. 
Table C.1. Analysis of the minimum ratio, across all sites, of maximum to minimum mean invertebrate density expected to be detectable by ANOVA, based on a conservative (base) pooled variance estimate and also on an upper $90 \%$ confidence limit for this estimate, for an ANOVA with data from four seasons at eleven sites on Bear Creek and at reference locations

\begin{tabular}{cccccc}
\hline \multirow{2}{*}{$\begin{array}{c}\text { Statistical } \\
\text { power }\end{array}$} & Number of & & \multicolumn{2}{c}{$\begin{array}{c}\text { Base pooled variance estimate: } \\
0.0696582(\mathrm{df}=127)^{c}\end{array}$} & $\begin{array}{c}\text { Upper 90\% confidence limit for } \\
\text { variance: }\end{array}$ \\
\cline { 2 - 6 } (1-Beta) & replicates & Alpha $=0.1$ & Alpha $=0.05$ & Alpha $=0.1$ & Alpha $=0.05$ \\
\hline 0.7 & 5 & 1.9 & 2.1 & 2.1 & 2.2 \\
& 3 & 2.3 & 2.6 & 2.6 & 2.9 \\
0.8 & 5 & 2.1 & 2.2 & 2.2 & 2.4 \\
& 3 & 2.6 & 2.9 & 2.9 & 3.2 \\
0.9 & 5 & 2.3 & 2.4 & 2.5 & 2.7 \\
& 3 & 2.9 & 3.3 & 3.3 & 3.7 \\
\hline
\end{tabular}

This estimate of the variance of log base-10 density values was chosen as the higher of the values obtained by analyzing separately data for Year 2 and Year 3. The number of degrees of freedom of this estimate, which was based on only three seasons because of dry conditions at one site in the fourth season, was used to obtain the upper $90 \%$ confidence limit. The results tabulated nonetheless reflect the full number of degrees of freedom expected for analyses involving four seasons. Levene's test for homogeneity of variance yielded $p \sim 0.01$.

Table C.2. Analysis of the minimum ratio, across all sites, of maximum to minimum mean invertebrate biomass expected to be detectable by ANOVA, based on a conservative (base) pooled variance estimate and also on an upper $90 \%$ confidence limit for this estimate, for an ANOVA with data from four seasons at eleven sites on Bear Creek and at reference locations

\begin{tabular}{cccccc}
\hline \multirow{2}{*}{$\begin{array}{c}\text { Statistical } \\
\text { power }\end{array}$} & Number of & & $\begin{array}{c}\text { Base pooled variance estimate: } \\
0.19130636(\mathrm{df}=174)^{a}\end{array}$ & $\begin{array}{c}\text { Upper 90\% confidence limit for } \\
\text { variance: }\end{array}$ \\
\cline { 3 - 6 } (1-Beta) & replicates & Alpha $=0.1$ & Alpha $=0.05$ & Alpha $=0.1$ & Alpha = 0.05 \\
\hline 0.7 & 5 & 2.9 & 3.3 & 3.2 & 3.7 \\
& 3 & 4.1 & 4.9 & 4.7 & 5.7 \\
0.8 & 5 & 3.3 & 3.7 & 3.7 & 4.2 \\
& 3 & 4.8 & 5.7 & 5.6 & 6.8 \\
0.9 & 5 & 3.9 & 4.4 & 4.4 & 5.1 \\
& 3 & 6.0 & 7.1 & 7.1 & 8.6 \\
\hline
\end{tabular}

${ }^{a}$ The source of this variance estimate is an ANOVA based on log base 10 of biomass from Year 3, for which Levene's test for homogeneity of variance yielded $p \sim 0.01$. For Year 2 , Levene's test for homogeneity of variance yielded $p \sim 0.0004$, and we elected not to use the pooled variance estimate from that year. 
Table C.3. Analysis of the minimum range, across all sites, of mean EPT species richness (number of taxa found of Ephemeroptera, Plecoptera, and Trichoptera) expected to be detectable by ANOVA, based on three levels of variance which should encompass the actual variances among replicates at individual sites ${ }^{a}$

\begin{tabular}{|c|c|c|c|c|c|c|c|}
\hline \multirow{2}{*}{$\begin{array}{c}\text { Statistical } \\
\text { power } \\
\text { (1-Beta) }\end{array}$} & \multirow{2}{*}{$\begin{array}{c}\text { Number } \\
\text { of } \\
\text { replicates }\end{array}$} & \multicolumn{2}{|c|}{ Assumed variance $=1$} & \multicolumn{2}{|c|}{ Assumed variance $=10$} & \multicolumn{2}{|c|}{ Assumed variance $=\mathbf{3 0}$} \\
\hline & & Alpha $=0.1$ & Alpha $=0.05$ & Alpha $=0.1$ & Alpha $=0.05$ & Alpha $=0.1$ & Alpha $=0.05$ \\
\hline \multirow[t]{2}{*}{0.7} & 5 & 1.1 & 1.2 & 3.3 & 3.8 & 5.8 & 6.5 \\
\hline & 3 & 1.4 & 1.6 & 4.4 & 5.0 & 7.7 & 8.6 \\
\hline \multirow[t]{2}{*}{0.8} & 5 & 1.2 & 1.3 & 3.7 & $\underline{4.1}$ & 6.5 & 7.2 \\
\hline & 3 & 1.6 & 1.7 & 4.9 & $\underline{5.5}$ & 8.5 & 9.5 \\
\hline \multirow[t]{2}{*}{0.9} & 5 & 1.3 & 1.5 & 4.3 & 4.6 & 7.4 & 8.1 \\
\hline & 3 & 1.8 & 1.9 & 5.6 & 6.2 & 9.7 & 10.7 \\
\hline
\end{tabular}

Note: The ANOVA is assumed to include data from 4 seasons at 11 sites on Bear Creek and at reference locations.

${ }^{a}$ No transformation could be found to achieve homogeneity of variance of the EPT richness data, even if a very broad acceptance criterion were used. Therefore, this wide range of values was selected to represent conditions ranging from pessimistic to optimistic, based on the observed variety of variances in individual cells of actual data from 15 sites in four seasons during Year 2. Underlined values in the table are discussed in the text.

Table C.4. Analysis of the minimum range, across all sites, of the mean of the square root of the total number of invertebrate taxa expected to be detectable by ANOVA, based on a conservative (base) pooled variance estimate and also on an upper $90 \%$ confidence limit for this estimate, for an ANOVA with data from four seasons at eleven sites on Bear Creek and at reference locations

\begin{tabular}{cccccc}
\hline \multirow{2}{*}{$\begin{array}{c}\text { Statistical } \\
\text { power }\end{array}$} & Number of & \multicolumn{2}{c}{$\begin{array}{c}\text { Base pooled variance estimate: } \\
0.3705(\mathrm{df}=150)^{a}\end{array}$} & \multicolumn{2}{c}{$\begin{array}{c}\text { Upper } 90 \% \text { confidence limit for } \\
\text { variance estimate: } 0.4530\end{array}$} \\
\cline { 3 - 6 } (1-Beta) & replicates & Alpha $=0.1$ & Alpha $=0.05$ & Alpha $=0.1$ & Alpha $=0.05$ \\
\hline 0.7 & 5 & 0.64 & 0.72 & 0.71 & 0.80 \\
& 3 & 0.85 & 0.96 & 0.94 & 1.06 \\
0.8 & 5 & 0.72 & 0.80 & 0.80 & 0.88 \\
& 3 & 0.95 & 1.05 & 1.05 & 1.16 \\
0.9 & 5 & 0.82 & 0.89 & 0.91 & 0.99 \\
& 3 & 1.08 & 1.18 & 1.20 & 1.31 \\
\hline
\end{tabular}

${ }^{a}$ This pooled variance estimate was the larger of two analyses using the square root of total species richness for Year 2. Three seasons and either 13 or 14 sites were included. Levene's test for homogeneity of variance yielded $p \sim 0.05$. 
Table C.5. Analysis of the minimum range, across all sites, of the mean of the ratio of EPT species richness to total invertebrate species richness expected to be detectable by ANOVA, based on a conservative (base) pooled variance estimate and also on an upper $90 \%$ confidence limit for this estimate, for an ANOVA with data from four seasons at eleven sites on Bear Creek and at reference locations

\begin{tabular}{cccccc}
\hline \multirow{2}{*}{$\begin{array}{c}\text { Statistical } \\
\text { power }\end{array}$} & Number of & & $\begin{array}{c}\text { Base pooled variance estimate: } \\
0.0104(\mathrm{df}=150)^{a}\end{array}$ & \multicolumn{2}{c}{$\begin{array}{c}\text { Upper 90\% confidence limit for } \\
\text { variance: }\end{array}$} \\
\cline { 3 - 6 } & $\begin{array}{c}\text { N-Beta }) \\
\text { replicates }\end{array}$ & Alpha $=0.1$ & Alpha $=0.05$ & Alpha $=0.1$ & Alpha $=0.05$ \\
\hline 0.7 & 5 & 0.11 & 0.12 & 0.12 & 0.13 \\
& 3 & 0.14 & 0.16 & 0.16 & 0.18 \\
0.8 & 5 & 0.12 & 0.13 & 0.13 & 0.15 \\
& 3 & 0.16 & 0.18 & 0.18 & 0.20 \\
0.9 & 5 & 0.14 & 0.15 & 0.15 & 0.17 \\
& 3 & 0.18 & 0.20 & 0.20 & 0.22 \\
\hline
\end{tabular}

This pooled variance estimate was the largest of three analyses using untransformed values of the ratio for Year 2. Three seasons and, variously, 13, 14, or 15 sites were included. Levene's test for homogeneity of variance yielded $p \sim 0.05$. 
Appendix D

CHECKLIST OF BENTHIC MACROINVERTEBRATE TAXA FROM BEAR CREEK APRIL 1985-APRIL 1993 

Table D.1. Checklist of benthic macroinvertebrate taxa collected from Bear Creek (BCK), April 1985 through April 1993

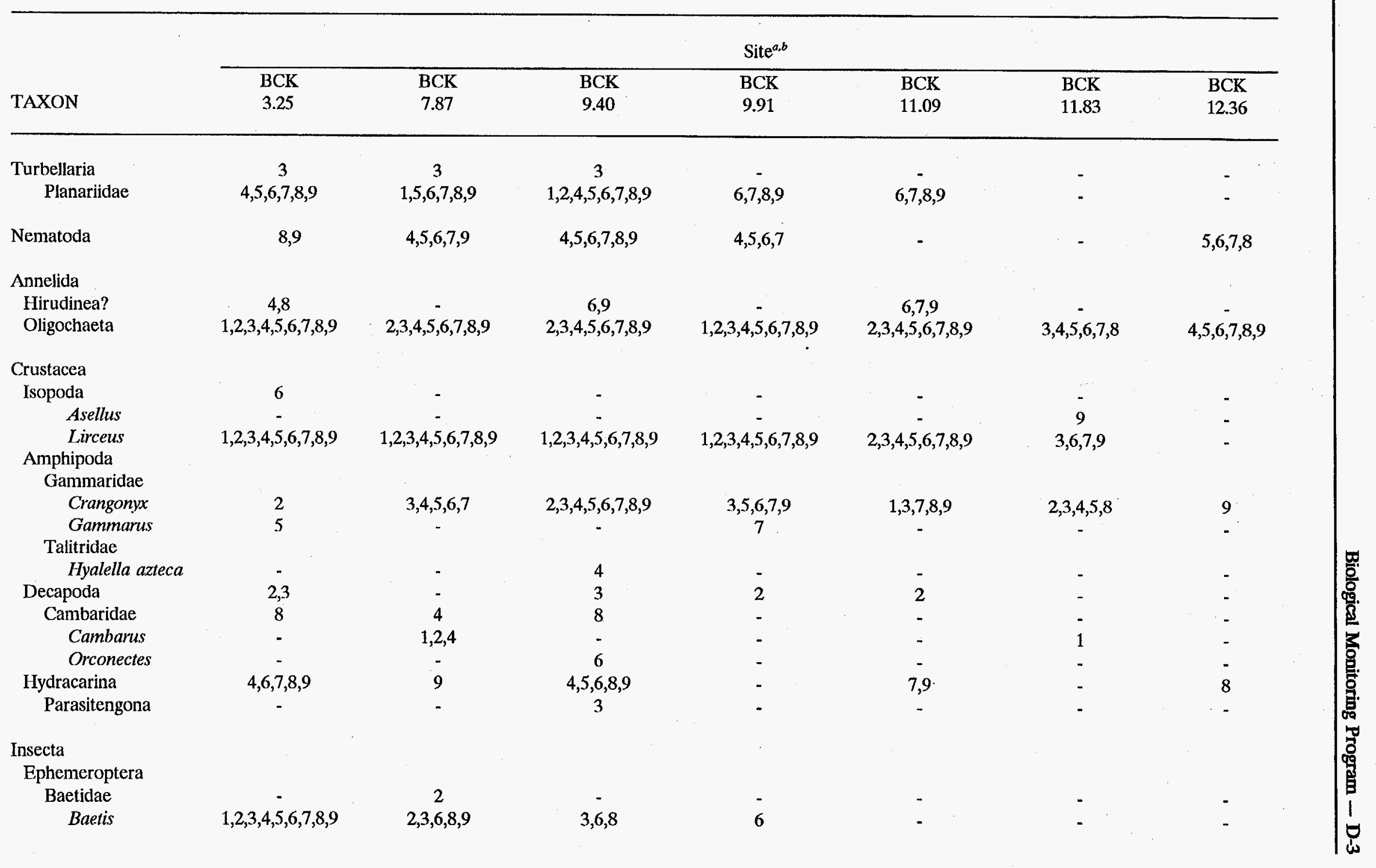


Table D.1 (continued)

\begin{tabular}{|c|c|c|c|c|c|c|c|}
\hline \multirow[b]{3}{*}{ TAXON } & \multicolumn{7}{|c|}{ Site $^{a, b}$} \\
\hline & $\mathrm{BCK}$ & BCK & BCK & BCK & BCK & $\overline{B C K}$ & BCK \\
\hline & 3.25 & 7.87 & 9.40 & 9.91 & 11.09 & 11.83 & 12.36 \\
\hline \multicolumn{8}{|l|}{ Insecta (continued) } \\
\hline Cloeon & - & - & - & - & 6 & 8 & - \\
\hline Pseudocloeon & $1,4,5,6,7,8,9$ & $1,4,5,6,7,8,9$ & $1,2,5,6,7,8$ & $5,6,7,8,9$ & $1,6,9$ & - & - \\
\hline Pseudocloeon? & - & - & - & - & - & 9 & - \\
\hline \multicolumn{8}{|l|}{ Caenidae } \\
\hline Caenis & 4 & 4,5 & - & - & - & - & - \\
\hline \multicolumn{8}{|l|}{ Ephemerellidae } \\
\hline Ephemerella & $2,3,4,8,9$ & - & - & - & . & - & - \\
\hline Eurylophella & 2 & 4,5 & - & - & - & - & - \\
\hline Heptageniidae & 9 & 7,9 & - & 9 & - & - & - \\
\hline Stenacron & $4,8,9$ & $5,6,8,9$ & 9 & - & - & - & - \\
\hline Stenonema & 5,6 & 4 & - & - & - & - & - \\
\hline \multicolumn{8}{|l|}{ Leptophlebiidae } \\
\hline Habrophlebeiodes & $3,4,6,7,8$ & - & - & : & $3,7,9$ & 5 & - \\
\hline Paraleptophlebia & $4,5,6,9$ & - & - & - & 4 & - & - \\
\hline \multicolumn{8}{|l|}{ Oligoneuriidae } \\
\hline Isonychia & $1,2,3,4,5,6,7,8,9$ & 8 & - & - & - & .. & - \\
\hline Isonychia? & - & - & - & 8 & - & - & - \\
\hline \multicolumn{8}{|l|}{ Odonata } \\
\hline \multicolumn{8}{|l|}{ Anisoptera } \\
\hline Aeshnidae & - & - & - & - & - & 8 & - \\
\hline Boveria vinosa & 7 & 5 & - & 6 & 6,7 & 7 & 6,7 \\
\hline Gomphidae & 5 & 8 & - & - & 3 & - & - \\
\hline Stylogomphus & & & & & & & \\
\hline albistylus & $2,3,4,5,8,9$ & 1,9 & 9 & - & - & - & - \\
\hline Libellulidae? & - & 4 & - & - & - & - & - \\
\hline
\end{tabular}


Table D.1 (continued)

\begin{tabular}{|c|c|c|c|c|c|c|c|}
\hline \multirow[b]{3}{*}{ TAXON } & \multicolumn{7}{|c|}{ Site $^{a, b}$} \\
\hline & $\mathrm{BCK}$ & $\mathrm{BCK}$ & BCK & $\mathrm{BCK}$ & BCK & BCK & BCK \\
\hline & 3.25 & 7.87 & 9.40 & 9.91 & 11.09 & 11.83 & 12.36 \\
\hline \multicolumn{8}{|l|}{ Odonata (continued) } \\
\hline \multicolumn{8}{|l|}{ Calopterygidae } \\
\hline \multicolumn{7}{|l|}{ Coenagrionidae } & 6 \\
\hline Orthoptera & - & - & - & - & 2 & - & - \\
\hline Plecoptera & 2 & - & - & - & - & ـ & - \\
\hline Capniidae & 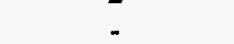 & 6,7 & - & . & - & - & - \\
\hline Allocapnia & $4,6,8,9$ & $4,5,8,9$ & $4,5,6,7,8,9$ & 4,5 & 5 & 9 & - \\
\hline \multicolumn{8}{|l|}{ Capniidae/ } \\
\hline Leuctridae & 5 & 5 & - & 5 & - & - & - \\
\hline \multicolumn{8}{|l|}{ Nemouridae } \\
\hline Amphinemura & $1,2,3,4,5,6,7,8,9$ & $1,2,3,4,5,6,7,8,9$ & $1,2,3,4,5,6,7,8,9$ & $1,2,3,4,5,6,7,8,9$ & $1,2,3,4,5,6,7,9$ & $2,3,4,5,6,7,8,9$ & $2,4,5,7,8,9$ \\
\hline Peltoperlidae & 3,5 & - & - & - & - & - & -2 \\
\hline Tallaperla & $1,4,5,6,7,8,9$ & 8,9 & - & - & - & - & _- \\
\hline Perlidae & $1,2,3,4,5,6$ & $1,2,3,4,5,7,8$ & $1,2,3$ & $3,4,5$ & 2,3 & $5,7,8$ & - \\
\hline Acroneuria & 9 & - & - & - & - & - & - \\
\hline \multicolumn{8}{|l|}{ Eccoptura } \\
\hline xanthenes & $2,4,5,6,7,8,9$ & $5,6,7,8,9$ & $3,5,6,7,8$ & $4,6,7,8,9$ & 7 & $4,5,7,8,9$ & 9 \\
\hline Perlesta & $4,6,7,8,9$ & $4,5,7,8,9$ & $5,6,7,8,9$ & $4,7,8,9$ & $4,5,6,7,8,9$ & $5,6,7,8,9$ & $6,7,8$ \\
\hline Perlodidae & $2,4,6$ & - & 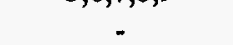 & - & -8 & - & - \\
\hline Isoperla & $3,5,6,7,8,9$ & $6,7,8,9$ & $1,3,5,6,7,8$ & $3,4,5,6,7,8,9$ & $1,2,3,4,5,6,7,9$ & $3,4,5,6,7,8,9$ & 6,8 \\
\hline Isoperla? & 4 & . & - & - & 6 & 5 & - \\
\hline
\end{tabular}












Table D.1 (continued)

\begin{tabular}{|c|c|c|c|c|c|c|c|}
\hline \multirow[b]{3}{*}{ TAXON } & \multicolumn{7}{|c|}{ Site $^{a, b}$} \\
\hline & BCK & BCK & BCK & BCK & BCK & BCK & BCK \\
\hline & 3.25 & 7.87 & 9.40 & 9.91 & 11.09 & 11.83 & 12.36 \\
\hline \multicolumn{8}{|c|}{ Coleoptera (continued) } \\
\hline Elmidae & - & . & 3 & - & - & - & - \\
\hline Dubiraphia & 5 & - & 8 & 7 & 3,9 & - & - \\
\hline \multicolumn{8}{|l|}{ Haliplidae } \\
\hline \multirow{2}{*}{\multicolumn{8}{|c|}{ Psephenidae }} \\
\hline & & & & & & & \\
\hline Ectopria & 4 & - & 3 & - & - & - & - \\
\hline \multicolumn{8}{|l|}{ Psephenus } \\
\hline \multicolumn{8}{|l|}{$\begin{array}{c}\text { herrckl } \\
\text { Ptilodactylidae }\end{array}$} \\
\hline Dasyhelea & - & - & 9 & - & . & - & 7,8 \\
\hline $\begin{array}{l}\text { Chironomidae } \\
\text { Chironominae }\end{array}$ & $4,5,6,7,8,9$ & $4,5,6,7,8,9$ & $4,5,6,7,8,9$ & $4,5,6,7,8,9$ & $4,5,6,7,8,9$ & $5,6,7,8,9$ & $5,6,7,8,9$ \\
\hline Chironomini & $2,3,4,5,6,7,8,9$ & $2,3,4,5,7,9$ & $2,4,5,6,7,8,9$ & $3,5,7,8,9$ & $3,6,7,8,9$ & $3,6,8$ & $5,6,7,9$ \\
\hline Tanytarsini & $2,3,4,5,6,7,8,9$ & $2,3,4,5,6,7,8,9$ & $2,3,4,5,6,7,8,9$ & $2,4,5,6,7,8,9$ & $4,5,6,7,8,9$ & $4,5,6,7,8,9$ & $4,5,6,7,8,9$ \\
\hline Diamesinae & - & 3 & - & 3 & - & - & - \\
\hline Orthocladiinae & $1,2,3,4,5,6,7,8,9$ & $1,2,3,4,5,6,7,8,9$ & $1,2,3,4,5,6,7,8,9$ & $1,2,3,4,5,6,7,8,9$ & $1,2,3,4,5,6,7,8,9$ & $1,2,3,4,5,6,7,8,9$ & \\
\hline $1,2,3,4,5,6,7,8,9$ & & & & & & & \\
\hline $\begin{array}{l}\text { Tanypodinae } \\
\text { Culicidae }\end{array}$ & $1,2,3,4,5,6,7,8,9$ & $1,2,3,4,5,6,7,8,9$ & $1,2,3,4,5,6,7,8,9$ & $1,2,3,4,5,6,7,8,9$ & $1,2,3,4,5,6,7,8,9$ & $2,3,4,5,6,7,8,9$ & $2,5,6,7,8,9$ \\
\hline $\begin{array}{l}\text { Anopheles } \\
\text { Dixidae }\end{array}$ & - & $\cdot$ & - & - & 2 & - & - \\
\hline
\end{tabular}




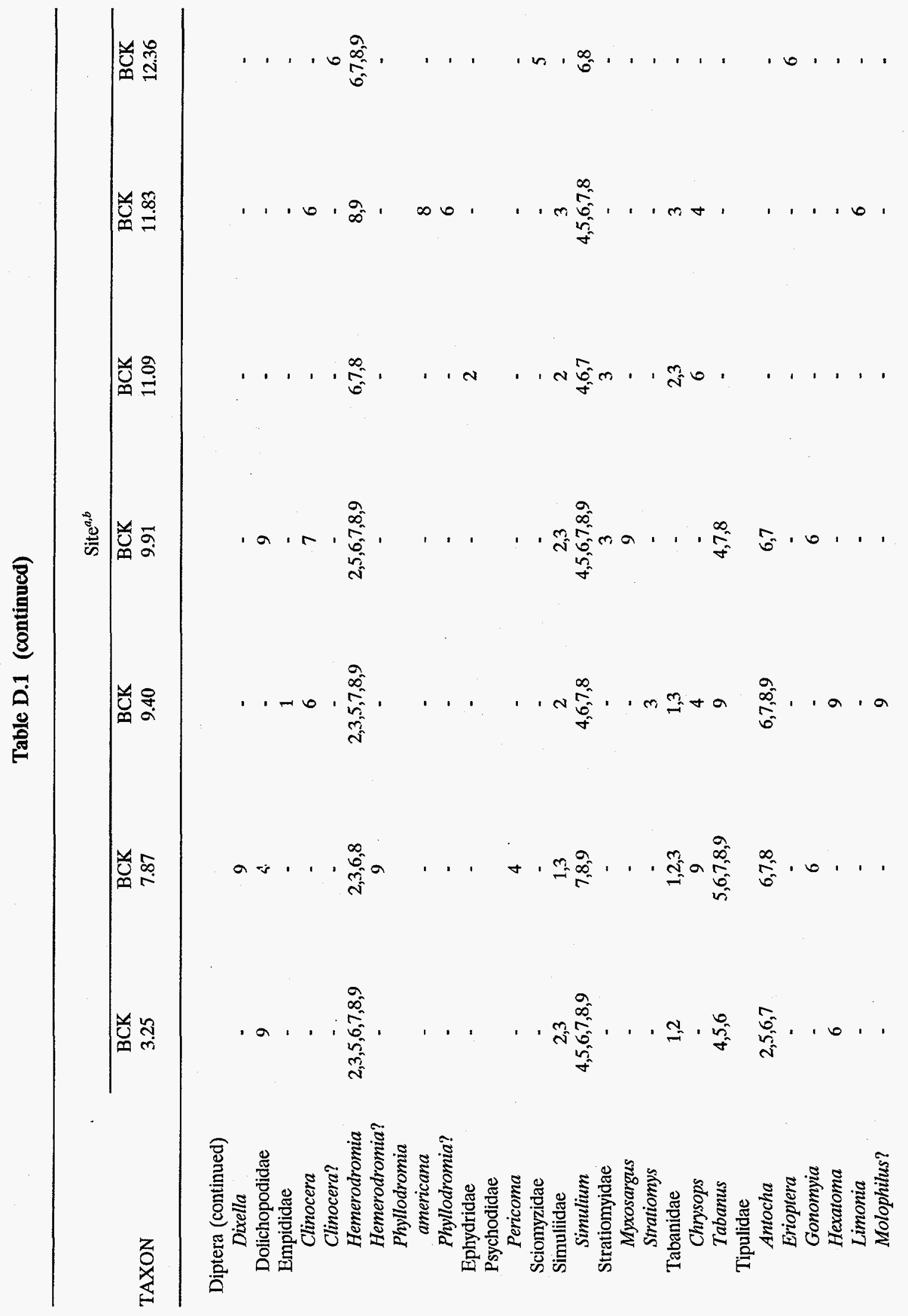


Table D.1 (continued)

\begin{tabular}{|c|c|c|c|c|c|c|c|}
\hline \multirow[b]{3}{*}{ TAXON } & \multicolumn{7}{|c|}{ Site $^{a, b}$} \\
\hline & BCK & $\begin{array}{l}\text { BCK } \\
787\end{array}$ & BCK & BCK & BCK & BCK & $\mathrm{BCK}$ \\
\hline & 3.25 & 7.87 & 9.40 & 9.91 & 11.09 & 11.83 & 12.36 \\
\hline \multicolumn{8}{|l|}{ Tipulidae (continued) } \\
\hline Pscudolimnophila & $1,4,8$ & 1 & 9 & - & - & - & - \\
\hline Tipula & $3,4,5,7$ & $1,3,6,7,9$ & $2,4,5,7,9$ & $2,7,9$ & 2 & 3,9 & 6 \\
\hline Tipula? & $\cdot$ & $\cdot$ & 7 & - & - & - & - \\
\hline \multicolumn{8}{|l|}{ Mollusca } \\
\hline \multicolumn{8}{|l|}{ Gastropoda } \\
\hline Lymnaeidae & - & - & - & 3 & 3,9 & - & - \\
\hline Fossaria & - & - & 3 & - & - & - & - \\
\hline \multicolumn{8}{|l|}{ Pseudosuccinea } \\
\hline columella & - & - & - & - & 9 & - & 6 \\
\hline \multicolumn{8}{|l|}{ Physidae } \\
\hline Physella & - & - & 4 & - & $2,5,6,8$ & 7 & 5,6 \\
\hline \multicolumn{8}{|l|}{ Pleuroceridae } \\
\hline Elimia & $1,2,3,4,5,6,7,8,9$ & - & 1 & - & - & - & - \\
\hline Pleurocera & 1,2 & - & - & - & - & - & - \\
\hline \multicolumn{8}{|l|}{ Bivalvia } \\
\hline \multicolumn{8}{|l|}{ Sphaeriidae } \\
\hline Sphaerium & - & - & 9 & - & - & - & . \\
\hline
\end{tabular}

${ }^{a} \mathrm{BCK}=$ Bear Creek kilometer.

${ }^{b}$ The numbers associated with each taxon and site indicate the year(s) during which at least one individual of a given taxon was collected during the April sampling periods, with $1=1985,2=1986,3=1987,4=1988,5=1989,6=1990,7=1991,8=1992$, and $9=1993$. A blank indicates that a lower level of classification (e.g., family, genus, or species) was possible at one or more sites, and a dash (-) indicates that the taxon was not collected or that the taxon was identified to lower level at one or more sites. 
Appendix E

CHECKLIST OF BENTHIC MACROINVERTEBRATE TAXA FROM BEAR CREEK REFERENCE SITES, APRIL 1985-APRIL 1993 

Table E.1. Checklist of benthic macroinvertebrate taxa collected from Bear Creek reference sites, April 1985 through April 1993

\begin{tabular}{|c|c|c|c|c|c|}
\hline \multirow[b]{3}{*}{ TAXON } & \multicolumn{5}{|c|}{ Site $e^{a, b}$} \\
\hline & GCK & GHK & GHK & MBK & UTK \\
\hline & 2.4 & 1.6 & 2.9 & 1.6 & 0.6 \\
\hline \multicolumn{6}{|l|}{ Turbellaria } \\
\hline Planariidae & $1,4,5,6,7,8,9$ & $4,5,6,7,8,9$ & $4,5,6,7,8,9$ & $4,5,6,7,8,9$ & $1,4,5,6,7,8,9$ \\
\hline Nematoda & $4,5,6,7,8,9$ & $2,4,5,8$ & $4,5,6,8$ & $3,4,5,7,9$ & $3,4,5,6,7$ \\
\hline \multicolumn{6}{|l|}{ Annelida } \\
\hline Hirudinea? & - & 5 & - & - & - \\
\hline Oligochaeta & $1,2,3,4,5,6,7,8,9$ & $1,2,3,4,5,6,7,8,9$ & $1,2,3,4,5,6,7,8,9$ & $1,2,3,4,5,6,7,8,9$ & $1,2,3,4,5,6,7,8,9$ \\
\hline \multicolumn{6}{|l|}{ Crustacea } \\
\hline \multicolumn{6}{|l|}{ Isopoda } \\
\hline Aseltus & 5,9 & 8 & - & - & - \\
\hline Lirceus & $4,5,6$ & $2,5,9$ & $1,3,4,5,6,7,8,9$ & $1,2,3,4,5,6,7,9$ & $1,2,3,4,5,6,7,8,9$ \\
\hline \multicolumn{6}{|l|}{ Amphipoda } \\
\hline \multicolumn{6}{|l|}{ Gammaridae } \\
\hline Crangonyx & $3,5,6,7,8,9$ & $2,4,6,7,9$ & $3,4,5$ & $3,6,7,8$ & $3,4,5,6,7,9$ \\
\hline Gammarus & - & - & - & - & 2 \\
\hline Decapoda & 2 & 2 & - & - & 3 \\
\hline Cambaridae & 4,8 & - & 5 & - & $4,5,9$ \\
\hline Cambarus & 1 & $1,2,3,4,8,9$ & 1,2 & 1 & $1,2,6,9$ \\
\hline Hydracarina & 5,9 & $5,6,7,8,9$ & 9 & $4,5,6,7,8,9$ & $4,5,6,8,9$ \\
\hline Parasitengona & - & 3 & - & - & - \\
\hline \multicolumn{6}{|l|}{ Insecta } \\
\hline \multicolumn{6}{|l|}{ Ephemeroptera } \\
\hline Baetidae & 1 & 2 & 4 & - & 3 \\
\hline Baetis & $1,2,3,4,5,6,7,8,9$ & $1,2,3,4,5,6,7,8,9$ & $1,2,3,4,5,6,7,8,9$ & $1,2,3,4,5,6,7,8,9$ & $1,2,3,4,5,6,7,8,9$ \\
\hline Cloeon? & - & - & - & 8 & - \\
\hline Pseudocloeon & $5,6,7,8,9$ & $4,5,6,7,8$ & 6,9 & $1,5,6,7,8$ & 1 \\
\hline Ephemerellidae & - & - & - & - & 7,9 \\
\hline Ephemerella & - & - & - & - & $1,2,3,4,5,6,7,8,9$ \\
\hline Eurylophella & 1,3 & $1,2,4,5,9$ & - & 1,5 & $1,2,3,4,5,6,7,8,9$ \\
\hline \multicolumn{6}{|l|}{ Ephemeridae } \\
\hline Ephemera & $1,2,3$ & $1,2,3,5$ & 1,2 & $1,2,3,4,5,9$ & $1,2,3,4,5,6,8,9$ \\
\hline Heptageniidae & 6 & $3,6,8$ & $\because$ & $3,5,6,9$ & $4,5,6,9$ \\
\hline Heptagenia & - & - & 1 & - & - \\
\hline Leucracuta & 1,3 & $2,3,4,5,7,8$ & $1,4,5,9$ & $2,3,4,5,6,7,8,9$ & - \\
\hline Stenacron & $2,3,5$ & $1,2,3,4$ & 3,4 & 5,9 & $1,2,3,4,5,6$ \\
\hline Stenonema & 3,9 & $1,2,3,4,5,8$ & $1,8,9$ & $1,2,3,4,5,8$ & $2,3,4,5,8,9$ \\
\hline Leptophlebiidae & 9 & 3 & 2 & - & 3 \\
\hline \multicolumn{6}{|l|}{ Habrophlebia } \\
\hline vibrans & - & 6 & 4,5 & 1 & - \\
\hline Habrophlebeiodes & $1,2,3,4,5,6,7,8,9$ & $1,3,4,5,6,7,8,9$ & $1,3,4,5,6,7,8,9$ & $1,2,3,4,5,6,7,8,9$ & $1,2,3,4,5,6,7,8,9$ \\
\hline Habrophlebeiodes? & - & 8 & - & - & - \\
\hline Paraleptophlebia & $4,5,6,7,8,9$ & $4,5,7,8$ & - & - & 2 \\
\hline Paraleptophlebia? & - & - & 8 & - & 8 \\
\hline \multicolumn{6}{|l|}{ Oligoneuriidae } \\
\hline Isonychia & - & $1,2,3,8$ & - & 3,9 & $1,2,3,4,5,6,7,8,9$ \\
\hline \multicolumn{6}{|l|}{ Siphlonuridae } \\
\hline Ameletus & - & - & 4 & - & 4 \\
\hline $\begin{array}{l}\text { Odonata } \\
\text { Anisoptera }\end{array}$ & & & & & \\
\hline
\end{tabular}


Table E.1 (continued)

\begin{tabular}{|c|c|c|c|c|c|}
\hline \multirow[b]{3}{*}{ TAXON } & \multicolumn{5}{|c|}{ Site $^{a, b}$} \\
\hline & GCK & GHK & GHK & MBK & UTK \\
\hline & 2.4 & 1.6 & 2.9 & 1.6 & 0.6 \\
\hline \multicolumn{6}{|l|}{ Odonata (continued) } \\
\hline \multicolumn{6}{|l|}{ Aeshnidae } \\
\hline Boyeria vinosa & 6,7 & - & - & 7 & - \\
\hline \multicolumn{6}{|l|}{ Cordulegastridae } \\
\hline Cordulegaster & - & - & $1,4,5,7$ & - & $3,7,8,9$ \\
\hline \multicolumn{6}{|l|}{ Stylogomphus } \\
\hline albistylus & $1,2,3,4,5,6,7,8,9$ & $3,4,5,6,7,8,9$ & $1,3,4,5,6,7,8,9$ & $1,2,3,4,5,6,7,8,9$ & $1,2,3,4,5,6,7,8,9$ \\
\hline Stylogomphus? & - & 5 & 4 & - & - \\
\hline \multicolumn{6}{|l|}{ Zygoptera } \\
\hline \multicolumn{6}{|l|}{ Calopterygidae } \\
\hline Calopteryx & - & - & - & - & 6,9 \\
\hline Calopteryx? & - & - & - & 5 & - \\
\hline \multicolumn{6}{|l|}{ Plecoptera } \\
\hline Capniidae & - & - & 4 & - & - \\
\hline Allocapnia & $4,5,6,7,8,9$ & $4,5,7,8,9$ & 5,9 & $4,5,6,7,8$ & $4,5,6,7,8,9$ \\
\hline \multicolumn{6}{|l|}{ Capniidae/ } \\
\hline Leuctridae & - & - & 4 & - & - \\
\hline Chloroperlidae & $1,3,8$ & $1,2,3,4,7,8,9$ & $1,2,3,4,5,9$ & $1,2,3,4$ & 2,3 \\
\hline Haploperla & $2,6,7,8,9$ & $2,4,5,6,7,8,9$ & $4,5,6,7,8,9$ & $3,4,5,6,7,8,9$ & $7,8,9$ \\
\hline Sweltsa & $2,5,6,7,8,9$ & $2,3,4,5,6,7,8,9$ & $2,4,5,6,7,8,9$ & $3,4,5,6,7,8,9$ & - \\
\hline Leuctridae & 2 & 2 & 2 & 2 & - \\
\hline Leuctra & $3,4,5,6,7,8,9$ & $1,3,4,5,6,7,8,9$ & $3,4,5,6,7,8,9$ & $3,4,5,6,7,8,9$ & $4,5,6,7,8,9$ \\
\hline \multicolumn{6}{|l|}{ Nemouridae } \\
\hline Amphinemura & $1,2,3,4,5,6,7,8,9$ & $1,2,3,4,5,6,7,8,9$ & $1,3,4,5,6,7,8,9$ & $1,2,3,4,5,6,7,8,9$ & $1,2,3,4,5,6,7,8,9$ \\
\hline Peltoperlidae & - & - & $3,6,7$ & - & - \\
\hline Tallaperla & 9 & $4,6,7,8,9$ & $3,5,8,9$ & $4,6,7$ & - \\
\hline \multicolumn{6}{|l|}{ Tallaperial } \\
\hline Peltoperla & - & - & 4 & - & - \\
\hline Perlidae & $1,2,7$ & $1,3,6$ & $1,2,3$ & $2,3,4,8$ & $1,2,3,6$ \\
\hline \multicolumn{6}{|l|}{ Eccoptura } \\
\hline xanthenes & $2,3,7,8,9$ & $2,3,4,5,6,7,8,9$ & $1,2,3,4,6,7,8$ & $2,3,4,5,6,7,8,9$ & $1,2,3,4,6,7,8,9$ \\
\hline Perlesta & $6,7,8$ & $4,5,6,7,8,9$ & $4,6,8$ & $4,5,6,7,8,9$ & $4,7,9$ \\
\hline Perlodidae & - & - & 5 & - & 8 \\
\hline Isoperla & 8,9 & $6,7,8,9$ & 9 & - & 7 \\
\hline \multicolumn{6}{|l|}{ Perlidae/ } \\
\hline Perlodidae & $4,5,6,7,8$ & $4,5,6,7,8,9$ & $4,5,6,7,8,9$ & $4,5,6,7,8,9$ & $4,5,6,7,8,9$ \\
\hline \multicolumn{6}{|l|}{ Taeniopterygidae } \\
\hline Taeniopteryx & 5,7 & $4,5,6,7,8$ & 9 & 6,7 & - \\
\hline \multicolumn{6}{|l|}{ Megaloptera } \\
\hline \multicolumn{6}{|l|}{ Corydalidae } \\
\hline \multicolumn{6}{|l|}{ Nigronia } \\
\hline fasciatus & $2,4,8,9$ & $1,8,9$ & $1,2,3,4,5,6,7,8$ & 2 & 2,4 \\
\hline \multicolumn{6}{|l|}{ Nigronia } \\
\hline serricomis & $2,3,5,7,8,9$ & $1,2,3,4,8$ & 5,9 & $2,3,5,6,7$ & $1,2,3,4,5,6,8,9$ \\
\hline Nigronia & - & - & 9 & - & - \\
\hline \multicolumn{6}{|l|}{ Sialidae } \\
\hline Sialis & 7,8 & 3 & 3 & 3 & $1,3,4,5,6$ \\
\hline $\begin{array}{l}\text { Trichoptera } \\
\text { Glossosomatidae }\end{array}$ & - & - & 2 & 3 & - \\
\hline
\end{tabular}


Table E.1 (continued)

\begin{tabular}{|c|c|c|c|c|c|}
\hline \multirow[b]{3}{*}{ TAXON } & \multicolumn{5}{|c|}{ Site $^{a, b}$} \\
\hline & GCK & GHK & GHK & MBK & UTK \\
\hline & 2.4 & 1.6 & 2.9 & 1.6 & 0.6 \\
\hline \multicolumn{6}{|l|}{ Trichoptera (continued) } \\
\hline Agapetus & 3 & $4,5,6,7,8,9$ & $3,4,5,6,7,8,9$ & $4,6,7,8,9$ & $6,7,8,9$ \\
\hline Glossosoma & - & $2,3,6,7,8,9$ & $7,8,9$ & $3,4,5,6,7,8,9$ & $2,6,9$ \\
\hline Glossosoma? & - & 8 & - & - & - \\
\hline \multicolumn{6}{|l|}{ Hydropsychidae } \\
\hline $\begin{array}{l}\text { Cheumatopsyche } \\
\text { Diplectrona }\end{array}$ & \multicolumn{5}{|c|}{ Diplectrona } \\
\hline modesta & $2,3,4,5,6,7,8,9$ & $2,6,7,8,9$ & $1,2,3,4,5,6,7,8,9$ & $2,3,4,6,7,8,9$ & $1,2,3,4,5,6,7,8,9$ \\
\hline Hydropsyche & - & 6,8 & - & 3,7 & 2 \\
\hline Hydroptilidae & 8 & - & - & 9 & 3,4 \\
\hline Hydroptila & 8 & 6 & - & 4,5 & $6,8,9$ \\
\hline Ochrotrichia & - & 4,8 & - & 4 & $4,5,7,9$ \\
\hline Oxyethira & 4 & - & - & - & - \\
\hline \multicolumn{6}{|l|}{ Lepidostomatidae } \\
\hline Lepidostoma & - & 9 & 3 & - & - \\
\hline \multicolumn{6}{|l|}{ Leptoceridae } \\
\hline Triaenodes & 2 & - & - & - & - \\
\hline \multicolumn{6}{|l|}{ Limnephilidae } \\
\hline Goera & - & 8 & 4,5 & - & 4,5 \\
\hline Hydatophylax & 3 & - & 3 & - & 3 \\
\hline Neophylax & $1,2,3,4,5,7,9$ & $1,2,3,4,5,6,7,8,9$ & $1,2,3,4,5,6,7,8,9$ & $1,2,3,4,5,6,7,8,9$ & $1,2,3,4,5,6,7,8,9$ \\
\hline $\begin{array}{l}\text { Pycnopsyche } \\
\text { Molannidae }\end{array}$ & 5 & - & $1,5,6$ & 5 & $1,2,4$ \\
\hline $\begin{array}{c}\text { Molanna } \\
\text { Odontoceridae }\end{array}$ & - & \multicolumn{3}{|c|}{ Odontoceridae } & 8,9 \\
\hline Psilotreta & $2,3,4,6,7,8,9$ & - . & $1,5,6$ & - & - \\
\hline Philopotamidae & - & - & 5 & - & - \\
\hline Chimarra & - & 8,9 & 7 & 5,7 & 4,6 \\
\hline Chimarra? & 8 & - & - & - & - \\
\hline \multicolumn{6}{|l|}{ Dolophilodes } \\
\hline distinctus & 6 & $3,4,5,6,7,8,9$ & 8,9 & - & 7,9 \\
\hline Wormaldia & $7,8,9$ & 9 & $3,5,7,8$ & 7 & - \\
\hline \multicolumn{6}{|l|}{ Polycentropodidae } \\
\hline \multicolumn{6}{|l|}{ Psychomyiidae } \\
\hline Lype diversa & - & - & - & - & $1,4,5,6,9$ \\
\hline \multicolumn{6}{|l|}{ Rhyacophilidae } \\
\hline Rhyacophila & $2,4,5,7,8,9$ & $3,4,5,6,7,8,9$ & $2,3,4,5,6,7,8,9$ & $2,3,6,7,9$ & $1,2,3,4,5,6,7,8,9$ \\
\hline Lepidoptera & - & 2 & - & - & - \\
\hline \multicolumn{6}{|l|}{ Coleoptera } \\
\hline \multicolumn{6}{|l|}{ Dryopidae } \\
\hline Helichus & - & - & - & $2,3,4$ & - \\
\hline \multicolumn{6}{|l|}{ Dytiscidae } \\
\hline Hydroporus & 6,7 & - & 5 & - & - \\
\hline Elmidae & 1 & 2 & - & - & - \\
\hline Dubiraphia & 3 & - & - & 5,9 & - \\
\hline \multicolumn{6}{|l|}{ Microcylloepus } \\
\hline pusillus & - & 7 & - & - & - \\
\hline Optiosenus & $1,2,3,4,5,6,7,8,9$ & $1,2,3,4,5,6,7,8,9$ & $1,2,3,4,5,6,7,8,9$ & $1,2,3,4,5,6,7,8,9$ & $1,2,3,4,5,6,7,8,9$ \\
\hline Oulimnius & & & & & \\
\hline latiusculus & - & $3,4,5,6,7,8$ & 9 & - & - \\
\hline
\end{tabular}


Table E.1 (continued)

\begin{tabular}{|c|c|c|c|c|c|}
\hline \multirow[b]{3}{*}{ TAXON } & \multicolumn{5}{|c|}{ Site ${ }^{a, b}$} \\
\hline & $\mathrm{GCK}$ & GHK & GHK & MBK & UTK \\
\hline & 2.4 & 1.6 & 2.9 & 1.6 & 0.6 \\
\hline Elmidae (continued) & & & & • & \\
\hline Stenelmis & $1,2,3,4,5,6,7,8,9$ & $1,2,3,4,5,6,7,8,9$ & $1,3,4,5,6,7,8,9$ & $3,4,5,6,7,8,9$ & $3,7,9$ \\
\hline \multicolumn{6}{|l|}{ Psephenidae } \\
\hline \multicolumn{6}{|l|}{ Alabameurbria } \\
\hline starki & 8 & - & - & - & - \\
\hline $\begin{array}{l}\text { Ectopria } \\
\text { Psephenus }\end{array}$ & $1,3,4,7,8,9$ & $4,7,9$ & $1,4,5,6,7,8,9$ & $3,4,5,7,8,9$ & $3,4,5,6,7,8,9$ \\
\hline & \multicolumn{4}{|c|}{ Ptilodactylidae } & $1,2,3,8$ \\
\hline \multicolumn{6}{|l|}{ Anchytarsus } \\
\hline Diptera & 2 & - & - & - & - \\
\hline Ceratopogonidae & $3,4,5,6,7,8,9$ & $1,3,4,5,6,7,8,9$ & $4,5,6,7,8,9$ & $3,4,5,6,7,8,9$ & $3,4,5,6,7,8,9$ \\
\hline Atrichopogon & 5 & - & - & - & $4,5,7$ \\
\hline Dasyhelea & - & - & 5 & - & - \\
\hline $\begin{array}{l}\text { Chironomidae } \\
\text { Chironominae }\end{array}$ & $4,5,6,7,8,9$ & $4,5,6,7,8,9$ & $4,5,6,7,8,9$ & $4,5,6,7,8,9$ & $4,5,6,7,8,9$ \\
\hline Chironomini & $1,2,3,4,5,6,7,8,9$ & $1,2,3,4,5,6,7,8,9$ & $1,2,3,4,5,6,7,8,9$ & $1,2,3,4,5,6,7,8,9$ & $1,2,3,4,5,6,7,8,9$ \\
\hline Tanytarsini & $2,3,4,5,6,7,8,9$ & $1,2,3,4,5,6,7,8,9$ & $1,2,3,4,5,6,7,8,9$ & $1,2,3,4,5,6,7,8,9$ & $1,2,3,4,5,6,7,8,9$ \\
\hline Orthocladinae & $1,2,3,4,5,6,7,8,9$ & $1,2,3,4,5,6,7,8,9$ & $1,2,3,4,5,6,7,8,9$ & $1,2,3,4,5,6,7,8,9$ & $1,2,3,4,5,6,7,8,9$ \\
\hline Podonominae & - & - & - & 9 & - \\
\hline Tanypodinae & $1,23,4,5,6,6,7,8,9$ & $1,2,3,4,5,6,7,8,9$ & $1,2,3,4,5,6,7,8,9$ & $1,2,3,4,5,6,7,8,9$ & $1,2,3,4,5,6,7,8,9$ \\
\hline \multicolumn{6}{|l|}{ Dixidae } \\
\hline Dixa & $3,7,9$ & 9 & $4,6,7,8$ & 1 & $1,3,4,6,7,9$ \\
\hline Dolichopodidae & 9 & 4 & - & 3,4 & - \\
\hline Dolichopodidae? & - & - & - & 4 & - \\
\hline \multicolumn{6}{|l|}{ Diptera } \\
\hline Empididae & - & - & - & 3 & - \\
\hline Clinocera & - & 8 & - & - & - \\
\hline Clinocera? & - & 8 & - & - & - \\
\hline Hemerodromia & 8 & $6,8,9$ & $4,6,8,9$ & $3,4,5,6,7,8$ & $3,4,5,6,7,8,9$ \\
\hline \multicolumn{6}{|l|}{ Psychodidae } \\
\hline Pericoma & - & - & 4 & 3 & 3,4 \\
\hline \multicolumn{6}{|l|}{ Pericomal } \\
\hline Telmatos & - & - & - & - & 4,5 \\
\hline Simuliidae & 3 & - & - & 2 & 3 \\
\hline Simulium & $5,7,8,9$ & $4,5,6,7,8,9$ & $6,7,8,9$ & $4,5,7,8,9$ & $6,7,8,9$ \\
\hline \multicolumn{6}{|l|}{ Stratiomyidae } \\
\hline Caloparyphus & - & - & - & - & 4 \\
\hline Tabanidae & 2,3 & 2,3 & 2 & 2,3 & - \\
\hline Tabanus & 6 & 8 & 4 & $4,5,6,7,9$ & - \\
\hline Tipulidae & $1,2,3$ & $1,2,3,4$ & $1,2,3$ & 2,3 & 2,3 \\
\hline Antocha & 7 & 8,9 & 2,6 & $1,2,3,6,7,8$ & $1,2,3,4,6,7,8,9$ \\
\hline Dicranota & - & 9 & 8 & - & - \\
\hline Erioptera? & - & - & 4 & - & - \\
\hline Hexatoma & $3,4,5,7,8,9$ & $4,7,8,9$ & $3,4,5,6,7,8,9$ & $1,4,5,6,7,8,9$ & - \\
\hline Limnophila & - & 9 & $4,5,6,7,8$ & $4,5,6,7$ & - \\
\hline Pilaria & 4 & - & - & 5 & - \\
\hline Pilaria? & 5 & - & - & - & - \\
\hline Pseudolimnophila & $1,4,5,6,7,8,9$ & $1,3,4,5,7,8,9$ & $1,5,9$ & $1,3,4,5,7,9$ & $1,3,4,6,7,8,9$ \\
\hline Tipula & 5,9 & $2,7,9$ & $1,2,3,4,5,7,8,9$ & $2,3,7$ & $1,2,3,4,5,6,7,8,9$ \\
\hline
\end{tabular}


Table E.1 (continued)

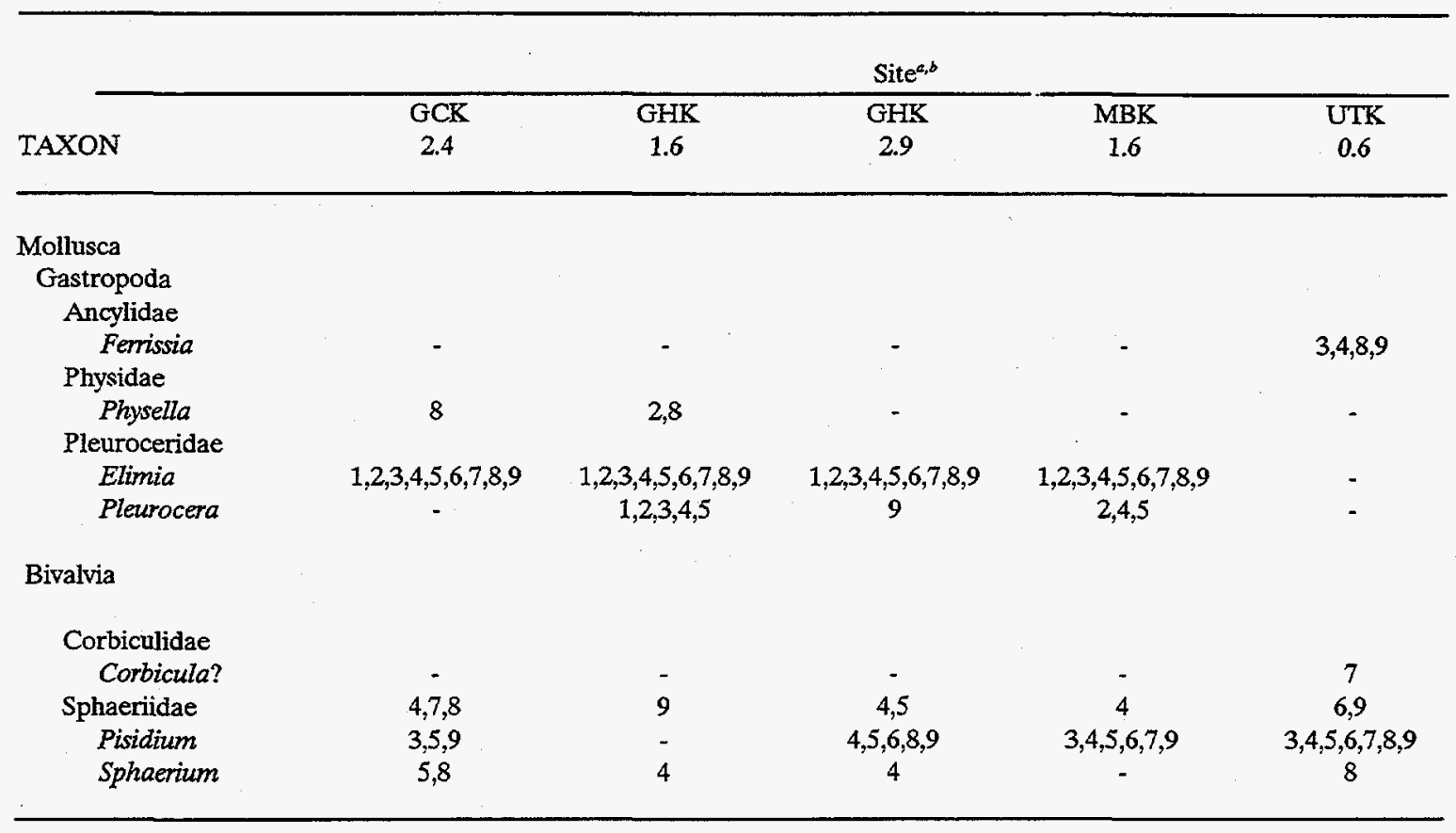

${ }^{a} \mathrm{GCK}=$ Grassey Creek kilometer; GHK = Gum Hollow Branch kilometer; MBK = Mill Branch kilometer; UTK = U.T. Farm Creek kilometer.

${ }^{5}$ The numbers associated with each taxon and site indicate the year(s) during which at least one individual of a given taxon was collected during the April sampling periods, with $1=1985,2=1986,3=1987,4=$ $1988,5=1989,6=1990,7=1991,8=1992$, and $9=1993$. A blank indicates that a lower level of classification (e.g., family, genus, or species) was possible at one or more sites, and a dash (-) indicates that the taxon was not collected or that the taxon was identified to lower level at one or more sites. 


\section{Appendix F}




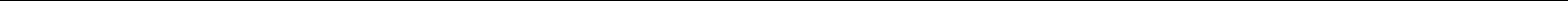




\title{
F. EVALUATION OF THE BENTHIC MACROINVERTEBRATE COMMUNITY IN LOWER BEAR CREEK DOWNSTREAM OF THE ORNL WHITE WING SCRAP YARD
}

\author{
(J. G. Smith and J. A. Wojtowicz)
}

\section{F.1 Introduction}

In 1992, sampling of the benthic macroinvertebrate community at a site in Bear Creek downstream of kilometer (BCK) 3.25 (see Fig. 5.11, this report) was initiated to help determine if other potential area source inputs may be impacting reaches of the stream that had not yet been studied. Specifically, an additional study site was established, and a sampling program initiated, at BCK 0.70 (Fig. 5.11, this report) in January 1992 to evaluate whether the ORNL White Wing Scrap Yard [Waste Area Group (WAG) 11] may be a potential source of impact to the lower reaches of the stream. The following is a summary of the results of samples collected in April and October 1992. Additional samples were not processed and evaluated for this analysis because it was felt that if no significant impacts could be detected during these two sampling periods further processing would be unnecessary, thus saving the costs associated with processing.

\section{F.2 Materials and Methods}

The procedures for collecting and processing benthic macroinvertebrate samples from $\mathrm{BCK} 0.70$ were the same as those used for the seven other Bear Creek sites that have been monitored since 1984; a complete description of these procedures is given in Section 5.2.2 of this report. Because BCK 3.25 has been found to be fully recovered from all impacts associated with upstream activities (see Section 5.2, this report), it served as a reference site for BCK 0.70. Statistical analyses included both descriptive and parametric techniques. The response variables, density (total number of organisms $/ 0.1 \mathrm{~m}^{2}$ ), total richness (total number of taxa/sample), and the total combined number of the Ephemeroptera, Plecoptera, and Trichoptera taxa (total number of EPT taxa/sample or EPT richness), were compared with a two-way analysis of variance (ANOVA) on site (fixed effect), sampling period (random effect), and their interaction term. A significance level value (i.e., $p$ ) of $<0.05$ was used to declare statistical significance. Prior to performing the ANOVAs, observed values for each response were transformed [i.e., $\log _{10}(X+1)$ for density values, and square root of $X$ for total and EPT richness values, where $X=$ the individual observed values for density, taxonomic richness, and EPT richness; Elliott 1977].

\section{F.3 Results}

Both sites were well represented by most major taxonomic groups (Table F.1). Particularly notable for both sites was the presence of several representative taxa within the Ephemeroptera, Plecoptera, and Trichoptera. The presence of several taxa within each of these groups is generally associated with good water quality (e.g., Lenat 1988). There were no outstanding differences between the two sites in taxonomic composition. 
Table F.1. Checklist of benthic macroinvertebrate taxa collected from Bear Creek sites BCK 0.70 and BCK 3.25, April and October 1992

Site $^{a, b}$

Taxon

BCK

BCK

0.70

3.25

Turbellaria

Planariidae

X

X

Nematoda

$\mathrm{X}$

$\mathrm{X}$

Annelida

Hirudinea?

Oligochaeta

$\mathrm{X}$

$\mathrm{X}$

$\mathrm{X}$

$\mathrm{X}$

Crustacea

Isopoda

Lirceus

$\mathrm{X}$

X

Decapoda

Cambaridae

Hydracarina

$\mathrm{X}$

$\mathrm{X}$

$\mathrm{X}$

$\mathrm{X}$

Insecta

Ephemeroptera

Baetidae

Baetis

Pseudocloeon

$\mathrm{X}$

$\mathrm{X}$

$\mathrm{X}$

Caenidae

Caenis

Ephemerellidae

Ephemerella

argo

Ephemerella?

Eurylophella

Eurylophella?

Heptageniidae

Stenacron

interpunctatum

Stenacron

Stenonema

Stenonema/Stenacron

$\mathrm{X}$

eptophlebiidae

Habrophlebiodes

Oligoneuriidae

Isonychia

$\mathrm{X}$

$\mathrm{X}$

X

X

$\mathrm{X}$

$-$

$\mathrm{X}$

$-$

$\mathrm{X}$

$\mathrm{X}$

$\mathrm{X}$

$\mathrm{X}$

$\mathrm{X}$

$-$

-

$\bar{x}$

$\mathrm{X}$

$\mathrm{X}$

$\mathrm{X}$

$\mathrm{X}$

$\mathrm{X}$

$\mathrm{X}$

X 
Table F.1 (continued)

Site ${ }^{\mathrm{ab}}$

Taxon

BCK

BCK

0.70

3.25

Ephemeroptera (continued)

Siphlonuridae

Ameletus

$\mathrm{X}$

Odonata

Anisoptera

Gomphidae

Stylogomphus

albistylus

$\mathrm{X}$

$\mathrm{X}$

Plecoptera

Capniidae

Allocapnia

Chloroperlidae

Sweltsa

$X$

$\mathrm{X}$

euctridae

Leuctra

Nemouridae

Amphinemura

Peltoperlidae

Tallaperla

Perlidae

Eccoptura xanthenes

Eccoptura?

Perlesta

$\bar{x}$

$X$

$\mathrm{X}$

$\mathrm{X}$

$\mathrm{X}$

$\mathrm{X}$

$\mathrm{X}$

$\mathrm{X}$

X

erlodidae

Isoperla holochlora

Isoperla namata

Perlidae/Perlodidae

$\mathrm{X}$

$\mathrm{X}$

$\mathrm{X}$

$\mathrm{X}$

-

Taeniopterygidae

Taeniopteryx

$\mathrm{X}$

-

$\mathrm{X}$

$\mathrm{X}$

$\mathrm{X}$

$\mathrm{X}$

X

$\mathrm{X}$

Megaloptera

Corydalidae

Nigronia

fasciatus

Nigronia serricornis

Sialidae

Sialis

X

$\mathrm{X}$

$\mathrm{X}$

$\mathrm{X}$ 
Table F.1 (continued)

Site $e^{a, b}$

Taxon

BCK

BCK

0.70

3.25

Trichoptera

Glossosomatidae

Agapetus

Glossosoma

X

$\mathrm{X}$

Hydropsychidae

Cheumatopsyche

Diplectrona modesta

Hydropsyche depravata

Hydroptilidae

Hydroptila

Ochrotrichia

Limnephilidae

Neophylax

Odontoceridae

Psilotreta labida

Philopotamidae

Chimarra

Psychomyiidae

Lype diversa

Rhyacophilidae

Rhyacophila

$\mathrm{X}$

X

$\mathrm{X}$

$-$

$\mathrm{X}$

$\mathrm{X}$

$\mathrm{X}$

-

$\mathrm{X}$

X

$\mathrm{X}$

$\mathrm{X}$

$\mathrm{X}$

$\mathrm{X}$

$\mathrm{X}$

$\mathrm{X}$

$\mathrm{X}$

$\mathrm{X}$

$\mathrm{X}$

Coleoptera

Elmidae

Dubiraphia

Optioservus

Stenelmis crenata

Stenelmis

Psephenidae

Psephenus herricki

Ptilodactylidae

Anchytarsus bicolor

$\mathrm{X}$

$\mathrm{X}$

$\mathrm{X}$

$\mathrm{X}$

$\mathrm{X}$

$\mathrm{X}$

$\mathrm{X}$

$\mathrm{X}$

$\mathrm{X}$

Diptera

Ceratopogonidae

Chironomidae

$\mathrm{X}$

X

Chironominae

Chironomini

Tanytarsini

Orthocladiinae

$x$

$\mathrm{X}$

$\mathrm{X}$

$\mathrm{X}$

$\mathrm{X}$

$\mathrm{X}$
$\mathrm{X}$
$\mathrm{X}$ 
Table F.1 (continued)

\begin{tabular}{|c|c|c|}
\hline \multirow[b]{2}{*}{ Taxon } & \multicolumn{2}{|c|}{ Site $^{a, b}$} \\
\hline & $\begin{array}{l}\mathrm{BCK} \\
0.70\end{array}$ & $\begin{array}{l}\mathrm{BCK} \\
3.25\end{array}$ \\
\hline \multicolumn{3}{|c|}{ Chironomidae (continued) } \\
\hline Tanypodinae & $\mathrm{X}$ & $\mathrm{X}$ \\
\hline \multicolumn{3}{|l|}{ Dixidae } \\
\hline Dixa & - & $\mathrm{X}$ \\
\hline Dixella & $\mathrm{X}$ & - \\
\hline \multicolumn{3}{|l|}{ Empididae } \\
\hline Hemerodromia & $\mathrm{X}$ & $\mathrm{X}$ \\
\hline \multicolumn{3}{|l|}{ Simuliidae } \\
\hline Simulium & $X$ & $\mathrm{X}$ \\
\hline \multicolumn{3}{|l|}{ Tipulidae } \\
\hline Antocha & $\mathrm{X}$ & $\mathrm{X}$ \\
\hline Pseudolimnophila & - & $\mathrm{X}$ \\
\hline Tipula & $\mathrm{X}$ & $\mathrm{X}$ \\
\hline \multicolumn{3}{|l|}{ Mollusca } \\
\hline Gastropoda & $\mathrm{X}$ & - \\
\hline \multicolumn{3}{|l|}{ Physidae } \\
\hline Physella & $X$ & - \\
\hline Pleuroceridae & $X$ & $\mathrm{X}$ \\
\hline Elimia & $X$ & $\mathrm{X}$ \\
\hline Pleurocera & - & $\mathrm{X}$ \\
\hline \multicolumn{3}{|l|}{ Bivalvia } \\
\hline \multicolumn{3}{|l|}{ Corbiculidae } \\
\hline Corbicula fluminea & $\mathrm{X}$ & - \\
\hline Sphaeriidae & & \\
\hline Sphaerium & $\mathrm{X}$ & - \\
\hline
\end{tabular}

${ }^{a} \mathrm{BCK}=\mathrm{Bear}$ Creek kilometer.

${ }^{5} \mathrm{An}$ " $\mathrm{X}$ " indicates that a taxon was collected at least once; a blank indicates that a lower level of classification (e.g., family, genus, or species) was possible at one or both sites, and a byphen (-) indicates that the taxon was not collected or that the taxon was identified to a lower level at one or more sites. 
Large differences were not seen between the sites in total density, total taxonomic richness, or EPT richness (Fig. F.1). The greatest difference occurred in density during the April sampling period, but then, the difference at that time was less than $2 \mathrm{x}$, a factor of difference common even among other Bear Creek reference sites (see Fig. 5.13, this report). Changes at the two sites in total density, total richness and EPT richness followed a similar pattern from the April to the October sampling period (ANOVA, $p>0.20$ for interaction between site and sampling period for all three parameters); statistically significant site differences also were not observed $(p>0.40$ for density and total richness and $p>0.07$ for EPT richness).

Except during the April sampling period at BCK 0.70 , the EPT taxa comprised at least $50 \%$ of the total density at both sites (Fig. F.2). Although the relative abundance of the EPT taxa at BCK 0.70 during the April sampling period was about $3 x$ less than at BCK 3.25 , it was common for the relative abundance of the EPT taxa at other Bear Creek reference sites to fall within a similar range as well (i.e., 15-20\%, Fig. 5.16, Section 5.2 this report). Total densities of the EPT taxa were also much lower at BCK 0.70 than at BCK 3.25 during the April sampling period (Fig. F.2), but their densities at $\mathrm{BCK} 0.70$ were comparable to those periodically observed at other Bear Creek reference sites from 1985 through 1993 (Fig. 5.17, Section 5.2 this report). Furthermore, the number of taxa contributing to the total density of each of these groups at both sites was comparable (Fig. F.2), thus, implying the presence of a taxonomically diverse community.

\section{F.4 Conclusions and Recommendations}

The benthic macroinvertebrate community at BCK 0.70 appears to be taxonomically diverse and structurally well balanced compared with BCK 3.25 and to other relatively unimpacted reference sites on and adjacent to the Oak Ridge Reservation. Differences did exist between BCK 0.70 and BCK 3.25 in community structure, but some differences would be expected between sites within a stream even under natural conditions (e.g., Hynes 1970; Vannote ct al. 1980). Unlike the impacted sites in Bear Creek, most major taxonomic groups were well represented by several taxa at BCK 0.70, including the Ephemeroptera, Plecoptera, and Trichoptera, taxa that are generally pollution-intolerant (e.g., Lenat 1988; Wiederholm 1984). Thus, these results imply that lower Bear Creek, as represented by BCK 0.70 , is not impacted by potential sources of contaminants downstream of BCK 3.25. It is therefore recommended that benthic macroinvertebrate sampling activities for the purpose of impact analysis cease. 

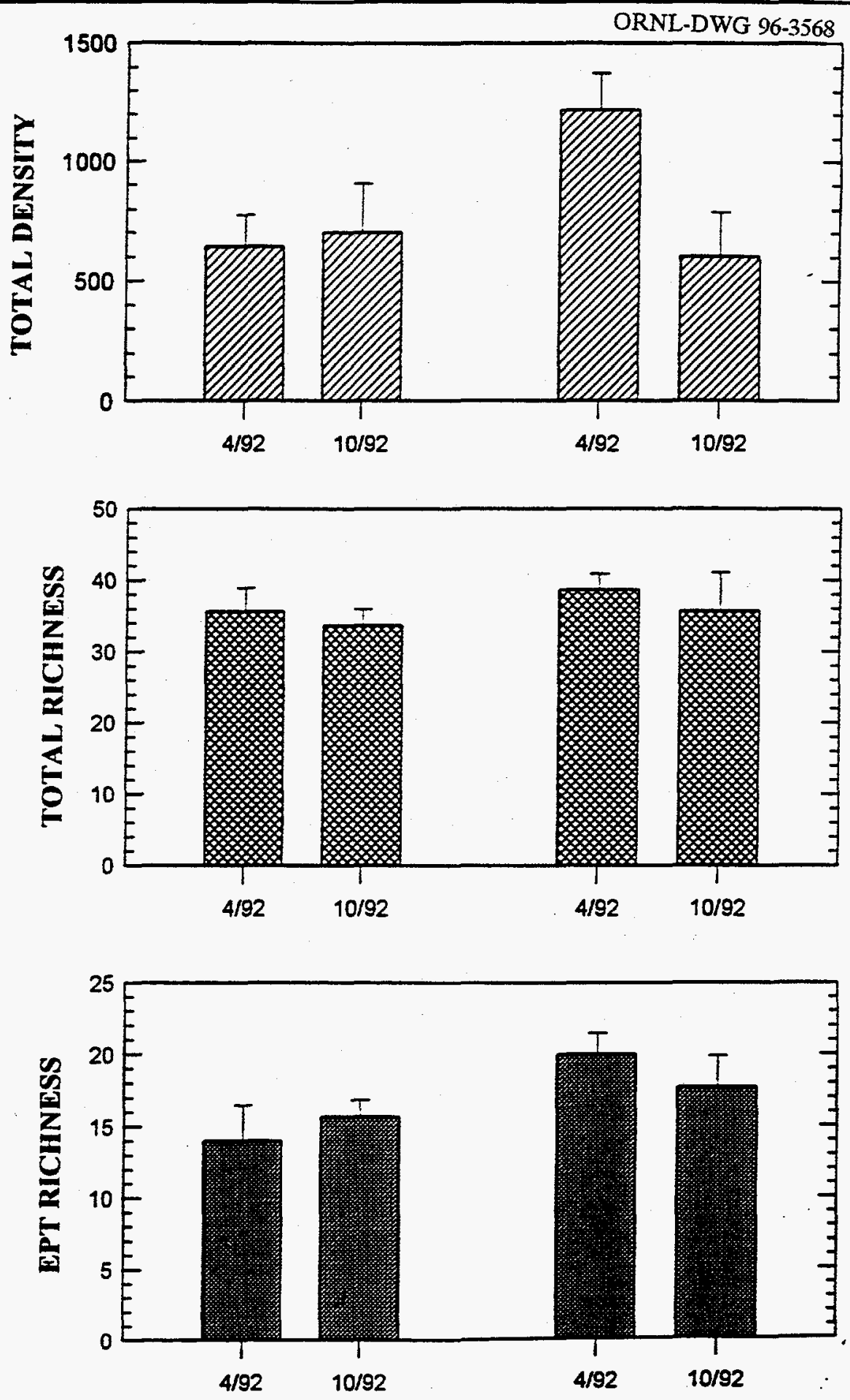

BCK 0.70

BCK 3.25

DATE/SITE

Fig. F.1. Mean total community density (number of organisms $/ 0.1 \mathrm{~m}^{2}$ ), total taronomic richness (number of taxa/sample), and richness of the Ephemeroptera, Plecoptera, and Trichoptera (number of EPT tadsample or EPT richness) at BCK 0.70 and BCK 3.25, April and October 1992. Vertical bars represent \pm 1 SE. $B C K=$ Bear Creek kilometer. 
CHIRONOMIDAE DIIA COLEOPTERA $\square$ EPT TAXA OTHERTAXA


$B C K 0.70$

$B C K 3.25$

DATE/SITE

Fig. F.2. Mean percent composition (i.e., mean percentage of total density) of selected benthic macroinvertebrate taxonomic groups (top) and mean densities of the Ephemeroptera, Plecoptera, and Trichoptera (bottom) at BCK 0.70 and BCK 3.25, April and October 1992. Vertical bars represent $\pm 1 \mathrm{SE}$. $\mathrm{BCK}=$ Bear Creek kilometer. 
Appendix G

BEAR CREEK BENTHIC MACROINVERTEBRATE REFERENCE SITE SIZE DIFFERENTIAL EVALUATION 







\section{G. COMPARATIVE EVALUATION OF THE EFFECTS OF STREAM SIZE ON BENTHIC MACROINVERTEBRATE COMMUNITY STRUCTURE OF BEAR CREEK REFERENCE SITES

\author{
(J. G. Smith)
}

\section{G.1 Introduction}

Longitudinal changes in benthic macroinvertebrate community composition and structure of streams have been documented, and they relate primarily to factors that are associated with changes that occur as stream size or watershed area increase (e.g., Hynes 1970; Minshall et al. 1985; Vannote et al. 1980). Thus, natural differences would be anticipated in the macroinvertebrate cominunity not only longitudinally in Bear Creek, but also among the reference sites used, and between the Bear Creek sites and reference sites since differences exist in their size and occurrence in different watersheds. However, apparently only subtle differences may exist in the community structure of streams that differ in size by only one or two stream orders, while much larger differences in stream size (e.g., differences $\geq 2$ stream orders) are needed before stream-size related

differences in community structure become detectable (Minshall et al. 1985).

From the upstream most sampling site to the downstream most site, Bear Creek changes in size from a second order stream (all reaches studied except BCK 3.25) to a third order stream (BCK 3.25), and the reference sites exhibit a similar range in stream order (Southwurth et al. 1992). In addition to this difference in size, there are also other obvious differences (e.g., depth, flow, and width; Southworth et al. 1992; J. G. Smith, ORNL/ESD, personal observation) that could conceivably contribute to differences in community structure among the sites. Because of these differences, several reference sites would ideally be used for each Bear Creek site. This would provide the best estimate of the natural range of reference conditions that could be expected among similarly sized stream sites, and would thus, improve the accuracy in evaluating the condition of each Bear Creek site. However, the time and costs associated with collecting and processing the extra samples would potentially be prohibitive and exceed the benefits of the extra data. Because of the relatively small size differences among the Bear Creek and reference sites (i.e., in terms of stream order - second order versus third order sites), and the indication that larger differences in stream size may be necessary to detect stream-size related differences (Minshall et al. 1985), the use of a large number of reference sites would appear to be unnecessary. However, since the potential for size-related differences does exist, a comparative analysis of the five Bear Creek reference sites was conducted to ascertain whether stream size needed to be taken into account when selecting reference sites for evaluating the condition and temporal changes of each Bear Creek site. Five reference sites were included in the analysis: one site each on Grassy Creek (GCK 2.4), Mill Branch (MBK 1.6), and UT Farm Creek (UTK 0.6) and two sites on Gum Hollow Branch (GHK 2.9 and 
GHK 1.6); GHK 2.9 and UTK 0.6 are both second order streams and GCK 2.4 , MBK 1.6, and GHK 1.6 are all third order streams. The locations of these sites are presented in Fig. 5.12 of this report, and selected physical characteristics for each site are given in Southworth et al. (1992).

\section{G.2 Materials and Methods}

The data set used for this analysis included only the reference site data used in the most recent analysjs of Bear Creek (see Section 5.2 of this report). As was done for the analysis of Bear Creek, the data set was limited to the April sampling periods from 1988 through 1993. This reduced any interferences potentially associated with the use of two different laboratories for processing the samples collected from 1984 to 1993 (see Section 5.2 of this report). Details of sample collection and processing are given in Section 5.2. The response variables analyzed included density (total number of organisms $/ 0.1 \mathrm{~m}^{2}$ ), total richness (total number of taxa/sample), and the total combined number of the Ephemeroptera, Plecoptera, and Trichoptera taxa (total number of EPT taxa/sample or EPT richness). For the analysis a two-way analysis of variance (ANOVA) on site (fixed effect), sampling period (random effect), and their interaction was used. A probability value (i.e., $p$ ) of $<0.05$ was used as the level of statistical significance. Where no significant interaction occurred between site and sampling date, a Tukey's studentized range test was used to separate site differences, accepting $p \leq 0.05$ as statistically significant. Prior to performing the ANOVAs, observed values for each response were transformed [i.e., $\log _{10}(X+1)$ for density values, and square root of $\mathrm{X}$ for total and EPT richness values, where $X=$ the individual observed values for density, taxonomic richness, and EPT richness; Elliott 1977].

\section{G.3 Results}

Mean values for density, total richness, and EPT richness for each April sampling period from 1988 through 1993 are presented in Figs. G.1, G.2, and G.3 respectively. Considerable variability was exhibited by each site across all 6 years of the study for all variables, but no statistically significant interaction was exhibited between site and sampling period for either variable, suggesting that in general all sites changed in a similar manner during the course of the study (Table G.1). It is possible however, that the variability among the sites was too large to allow the statistical separation of sites in their general patterns of change. If this were true, a significant interaction would have been indicative of the presence of a strong difference among two or more sites.

A statistically significant site effect was indicated by the ANOVA for each variable (Table G.1). Separation of site differences with a Tukey's test indicated that for density, statistical differences existed only between GHK 1.6 and GCK 2.4 (Table G.2). During each sampling period GCK 2.4 exhibited the lowest or next to the lowest density values, while GHK 1.6 exhibited the highest or next to highest values in all but one sampling period (Fig. G.1).

Statistically significant site effects were also observed for total richness and EPT richness (Table G.1). The outcome of the Tukey's test indicated that in general, values for both variables were significantly less at GCK 2.4 than at the other sites, with only total richness values for UTK 0.6 being statistically similar to those of GCK 2.4 (Table G.2). Total richness 
ORNL-DWG 96-3570

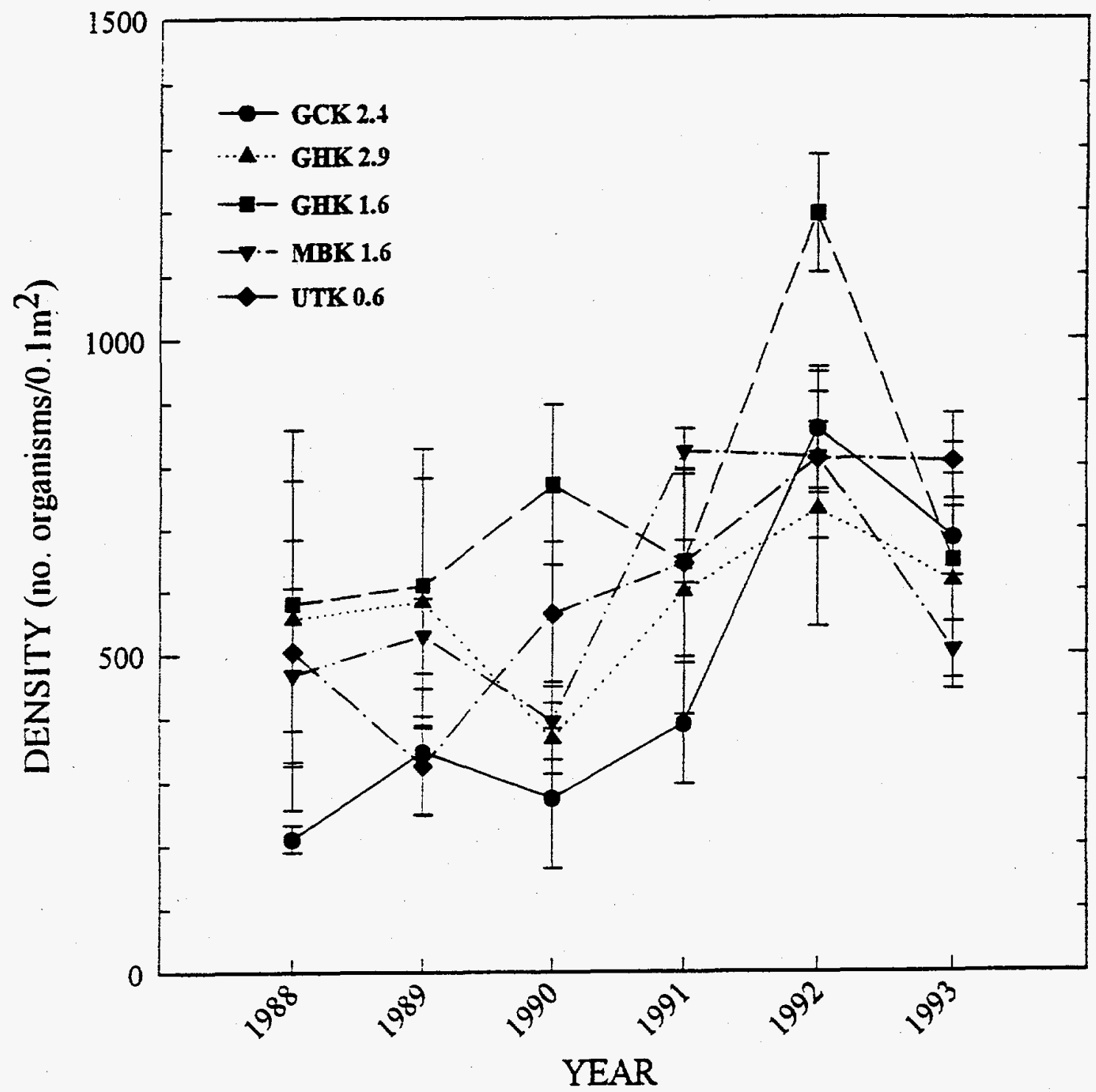

Fig. G.1. Mean densities of benthic macroinvertebrates collected at Bear Creek benthic macroinvertebrate reference sites during the April sampling periods from 1988 to 1993 . Values are the means $\pm 1 \mathrm{SE}$. GCK = Grassy Creek kilometer; GHK = Gum Hollow Branch kilometer; MBK = Mill Branch kilometer; UTK = UT Farm Creek kilometer. 
ORNL-DWG 96-3571

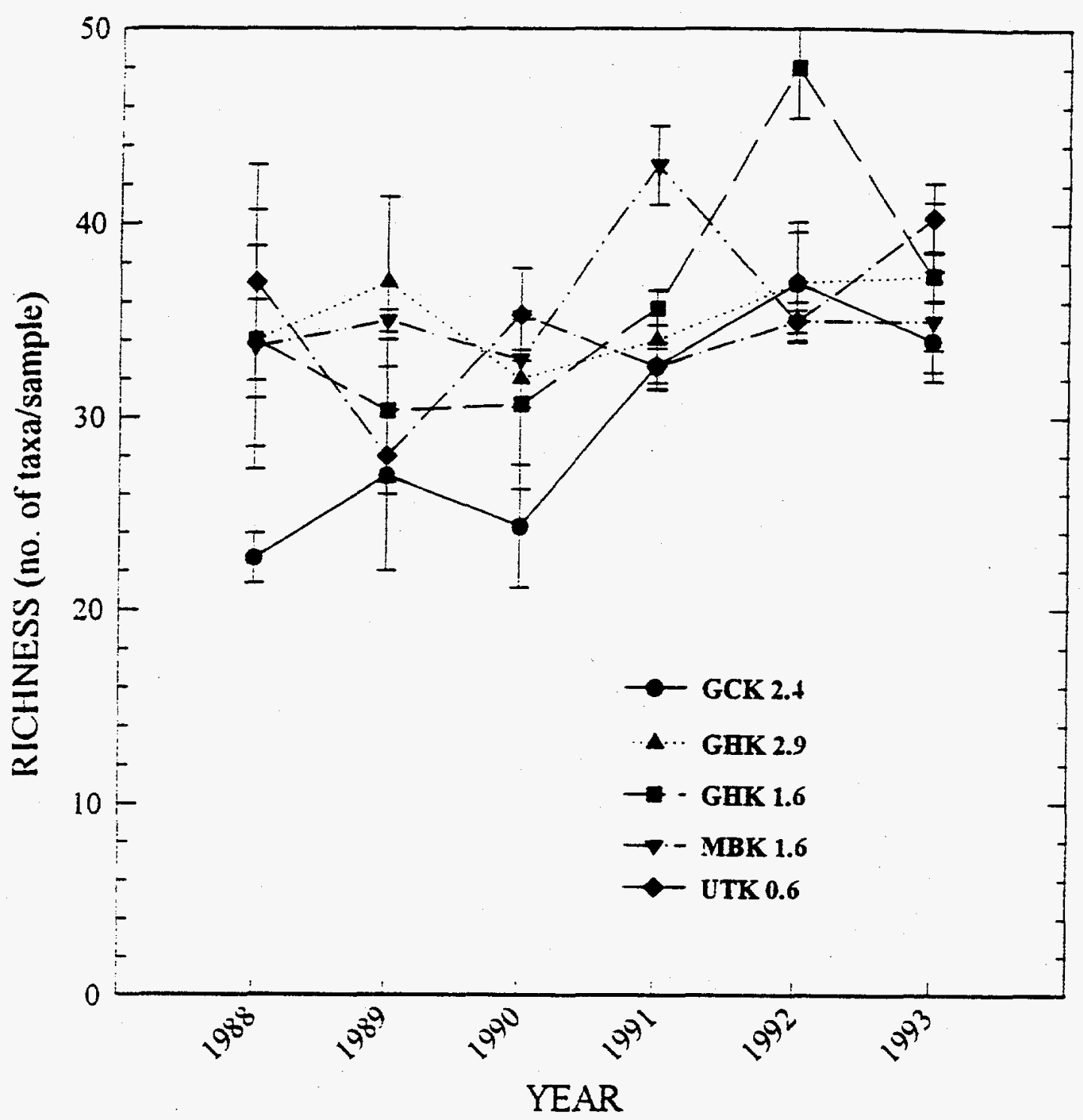

Fig. G.2. Mean total richness of benthic macroinvertebrate communities of the Bear Creek benthic macroinvertebrate reference sites during the April sampling periods from 1988 to 1993. Values are the means $\pm 1 \mathrm{SE}$. GCK $=$ Grassy Creek kilometer; GHK $=$ Gum Hollow Branch kilometer; $\mathrm{MBK}=$ Mill Branch kilometer; UTK $=$ UT Farm Creek kilometer. 
ORNL-DWG 96-3572

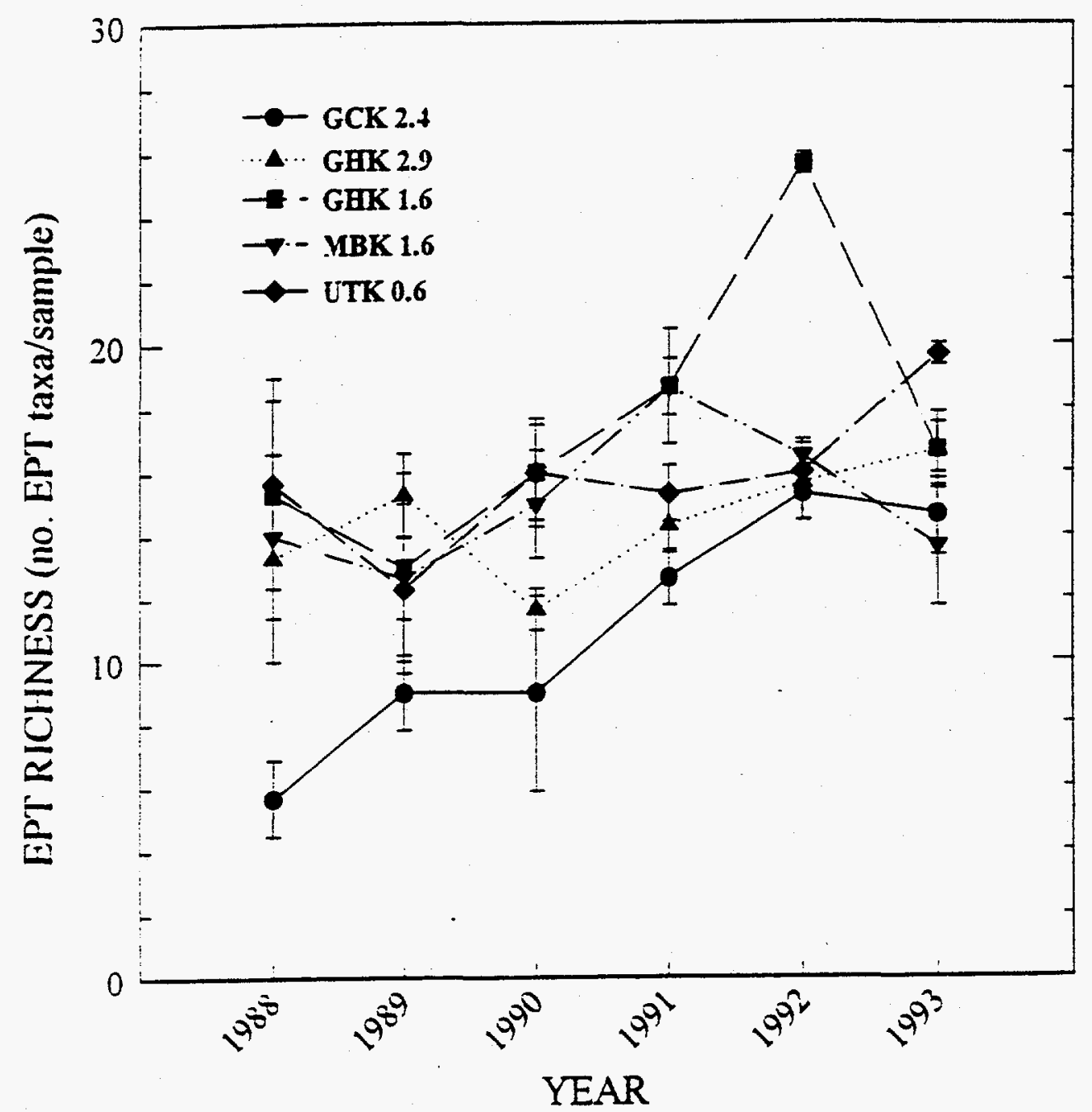

Fig. G.3. Mean richness of the Ephemeroptera, Plecoptera, and Trichoptera (EPT richness) of the benthic macroinvertebrate communities of the Bear Creek benthic macroinvertebrate reference sites during the April sampling periods from 1988 to 1993 . Values are the means \pm 1 SE. GCK $=$ Grassy Creek kilometer; GHK $=$ Gum Hollow Branch kilometer; $M B K=$ Mill Branch kilometer; UTK = UT Farm Creek kilometer. 
Table G.1. F-values and $p$-values for two-way analysis of variance (ANOVA) on the response variables density, total richness, and EPT richness, for Bear Creek reference sites, April 1988 - April 1993 ${ }^{\text {b, }}$

\begin{tabular}{|c|c|c|c|c|c|c|c|c|}
\hline \multirow[b]{2}{*}{ Source of variation } & \multicolumn{2}{|c|}{$\mathbf{d} \mathbf{f}^{d}$} & \multicolumn{2}{|c|}{ Density } & \multicolumn{2}{|c|}{ Total richness } & \multicolumn{2}{|c|}{ EPT richness } \\
\hline & Num & Den & F-value & $\overline{p \text {-value }}$ & F-value & $p$-value & F-value & $\overline{p \text {-value }}$ \\
\hline Site & 4 & 59 & 3.17 & 0.0198 & 4.16 & 0.0049 & 10.42 & 0.0001 \\
\hline Sample Year & 5 & 59 & 6.21 & 0.0001 & 4.59 & 0.0013 & 6.99 & 0.0001 \\
\hline Site*Sample Year & 20 & 59 & 0.82 & 0.6781 & 1.42 & 0.1487 & 1.62 & 0.0771 \\
\hline
\end{tabular}

${ }^{a} \mathrm{EPT}=$ Ephemeroptera, Plecoptera, and Trichoptera.

${ }^{b}$ Reference sites include Grassy Creek kilometer 2.4, Gum Hollow Branch kilometers 2.9 and 1.6, Mill Branch kilometer 1.6, and UT Farm Creek kilometer 0.6.

${ }^{c}$ Analyses included data from samples collected only during the April sampling periods of each year.

${ }^{d} \mathrm{df}=$ degrees of freedom; Num = numerator; Den = Denominator 
Table G.2. Results of the Tukey's studentized range test on the response variables density, total richness, and richness of the Ephemeroptera, Plecoptera, and Trichoptera (EPT richness) for Bear Creek reference sites, April 1988-April 1993

\begin{tabular}{lrrrr}
\multicolumn{5}{c}{ Density } \\
GHK 1.6 & UTK 0.6 & MBK 1.6 & GHK 2.9 & GCK 2.4 \\
\hline
\end{tabular}

Total Richness

$\begin{array}{lllll}\text { MBK 1.6 } & \text { GHK } 1.6 & \text { GHK } 2.9 & \text { UTK } 0.6 & \text { GCK } 2.4\end{array}$

EPT Richness

GHK 1.6 UTK $0.6 \quad$ MBK $1.6 \quad$ GHK $2.9 \quad$ GCK 2.4

Note: Sites not connected by the same line are significantly different $(p \leq 0.05)$. Sites are arranged in order of highest to lowest values from left to right. GCK = Grassy Creek kilometer; GHK = Gum Hollow Branch kilometer; MBK = Mill Branch kilometer; UTK = UT Farm Creek kilometer.

values at the reference sites generally ranged between 30 and 38 taxa per sample except at GCK 2.4 where the average number of taxa collected per sample was $<30$ during three of the sampling periods (Fig. G.2); total richness values were also lowest at GCK 2.4 in four of six sampling periods. Similarly, with few exceptions EPT richness values for the reference sites generally ranged from 11 to 14 EPT taxa per sample except at GCK 2.4 where the number of EPT taxa per sample was $<10$ during three of the sampling periods (Fig. G.3). Furthermore, mean values for
EPT richness were lowest at GCK 2.4 during five of the six sampling periods.

\section{G.4 Conclusions and Recommendations}

Except for GCK 2.4, a third order reference site, no strong or distinct differences were observed among the reference sites for the response variables evaluated. The lack of difference among the remaining four sites, comprised of two second order and two third order streams, suggests that if any differences existed in 
community structure that were associated with stream size, they were subtle or the available data did not provide sufficient statistical power to declare the observed difference significant. The reason why GCK 2.4 differed from the other sites to the extent that it did is not known. Differences have also been observed among reference sites used for the ORNL BMAP, all of which are second order stream sites (Smith 1993), suggesting that the differences observed for GCK 2.4 may fall within the normal range of small streams on and adjacent to ORR. In the absence of any discernable, strong differences among the reference sites that could be associated with stream size, limiting comparisons of each Bear Creek site to a subset of the reference sites based on stream size is not justified and thus unnecessary. By using all five reference sites for each Bear Creek site, a better estimate of the range of natural conditions is available from which the condition and long-term change of each site can be evaluated. 


\section{INTERNAL DISTRIBUTION}
1. S. M. Adams
2. L. D. Bates
3. J. J. Beauchamp
4. B. A. Berven
5. G. F. Cada
6. B. A. Carrico
7. S. W. Christensen
8. E. T. Collins
9. R. B. Cook
10. V. H. Dale
11. D. E. Fowler
12. C. S. Haase
13. K. D. Ham
14. P. L. Henry
15. S. G. Hildebrand
16. C. C. Hill
17. W. R. Hill
18-27. R. L. Hinzman
28. J. A. Hodgins
29. D. B. Jones
30. P. Kanciruk
31. L. A. Kszos
32. J. M. Loar
33. L. W. McMahon
34. J. Q. Miller
35. G. E. Napolitano
36. M. J. Peterson
37. T. L. Phipps
38. W. K. Roy
39. M. G. Ryon
40. B. E. Sample
41. E. M. Schilling
42. D. S. Shriner
43. J. G. Smith
44. M. R. Smith
45. G. R. Southworth
46. A. J. Stewart
47. S. H. Stow
48. G. W. Suter
49. L. O. Vaughn
50. L. F. Wicker
51-55. M. C. Wiest
56. J. A. Wojtowicz
57. Central Research Library
58. ESD Library
59-60. Laboratory Records Dept.
61. Laboratory Records, ORNL-RC
62. ORNL Patent Section
63. ORNL Y-12 Technical Library

\section{EXTERNAL DISTRIBUTION}

64. M. Broido, Acting Director, Environmental Sciences Division, Department of Energy, 19901 Germantown Road, Germantown, MD 20874

65. E. B. Bryant, Science Applications International Corporation, 301 Laboratory Road, Oak Ridge, TN 37931

66. F. A. Donath, Director, Institute for Environmental Education, Geological Society of America, 1006 Las Posas, San Clemente, CA 92673

67. D. W. Freckman, Director, College of Natural Resources, 101 Natural Resources Building, Colorado State University, Fort Collins, CO 80523

68. J. F. Heitman, Jaycor, Inc., 601-D Scarboro Road, Oak Ridge, TN 37830

69. D. R. Lindbom, Tennessee Department of Environment and Conservation, Department of Energy Oversight Agency, 761 Emory Valley Road, Oak Ridge, TN 37830

70. A. Patrinos, Associate Director, Office of Health and Environmental Research, Department of Energy, G-165, Germantown, MD 20874

71. G. S. Sayler, Professor, 10515 Research Drive, Suite 100, The University of Tennessee, Knoxville, TN 37932-2567 
72. A. W. McWhorter, Jaycor, Inc., 601-D Scarboro Road, Oak Ridge, TN 37830

73. Office of Assistant Manager for Energy Research and Development, U.S. Department of Energy Oak Ridge Operations, P.O. Box 2001, Oak Ridge, TN $37831-8600$

74-75. Office of Scientific and Technical Information, P.O. Box 62, Oak Ridge, TN 37831 